\title{
Evaluation of Street Sweeping as a Stormwater- Quality-Management Tool in Three Residential Basins in Madison, Wisconsin
}
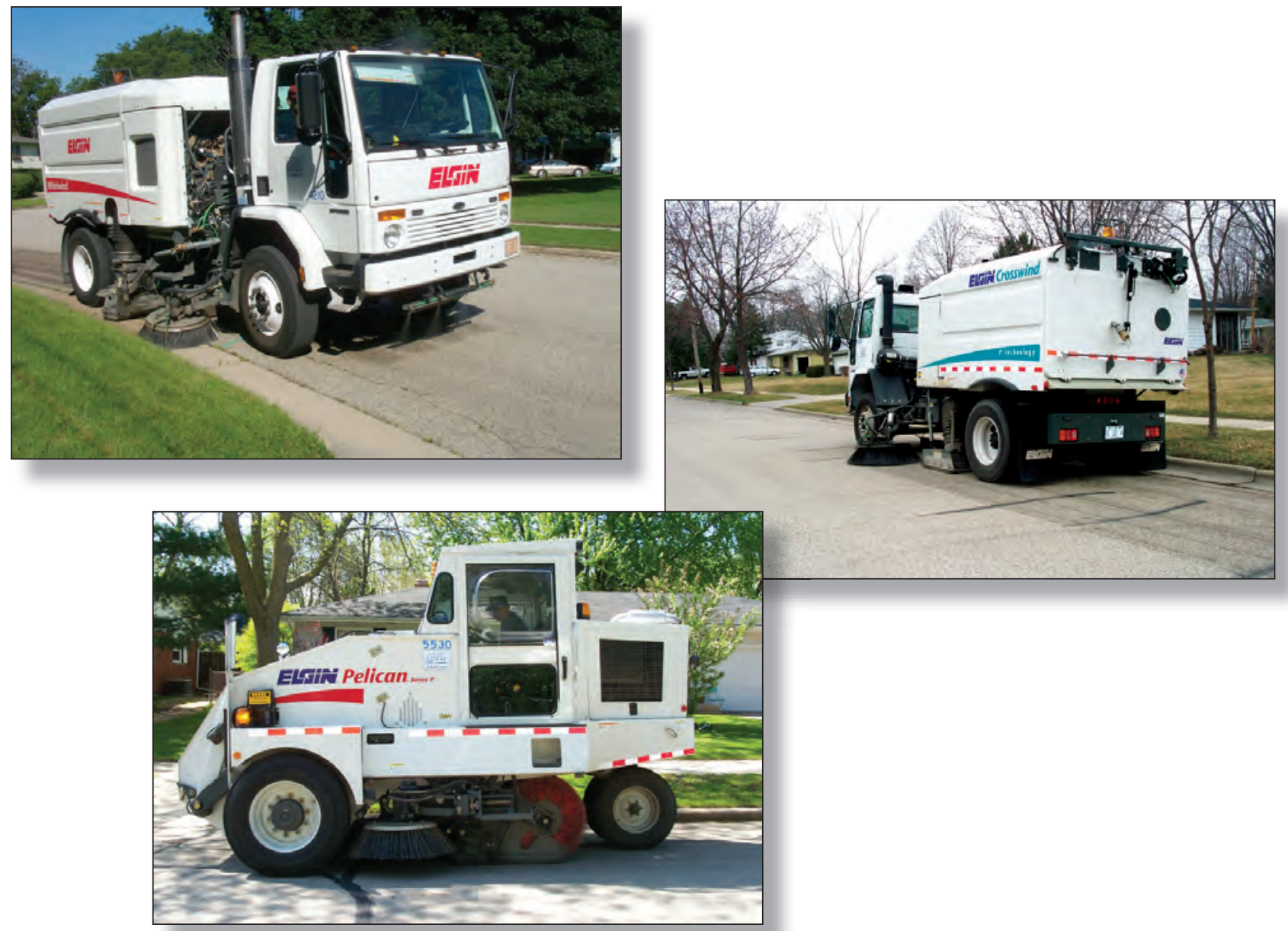

Scientific Investigations Report 2007-5156 



\section{Evaluation of Street Sweeping as a Stormwater-Quality-Management Tool in Three Residential Basins in Madison, Wisconsin}

By William R. Selbig and Roger T. Bannerman

In cooperation with the City of Madison, Wisconsin, and

the Wisconsin Department of Natural Resources

Scientific Investigations Report 2007-5156

U.S. Department of the Interior

U.S. Geological Survey 


\section{U.S. Department of the Interior DIRK KEMPTHORNE, Secretary}

\section{U.S. Geological Survey \\ Mark D. Myers, Director}

\section{U.S. Geological Survey, Reston, Virginia: 2007}

For product and ordering information:

World Wide Web: http://www.usgs.gov/pubprod

Telephone: 1-888-ASK-USGS

For more information on the USGS — the Federal source for science about the Earth, its natural and living resources, natural hazards, and the environment:

World Wide Web: http://www.usgs.gov

Telephone: 1-888-ASK-USGS

Any use of trade, product, or firm names is for descriptive purposes only and does not imply endorsement by the U.S. Government.

Although this report is in the public domain, permission must be secured from the individual copyright owners to reproduce any copyrighted materials contained within this report.

Suggested citation:

Selbig, W.R., and Bannerman, R.T., 2007, Evaluation of street sweeping as a stormwater-quality-management tool in three residential basins in Madison, Wisconsin: U.S. Geological Survey Scientific Investigations Report 2007-5156, 103 p.

Cover photos (clockwise from top):

Vacuum assist, regenerative air, and mechanical broom street sweepers. 


\section{Contents}

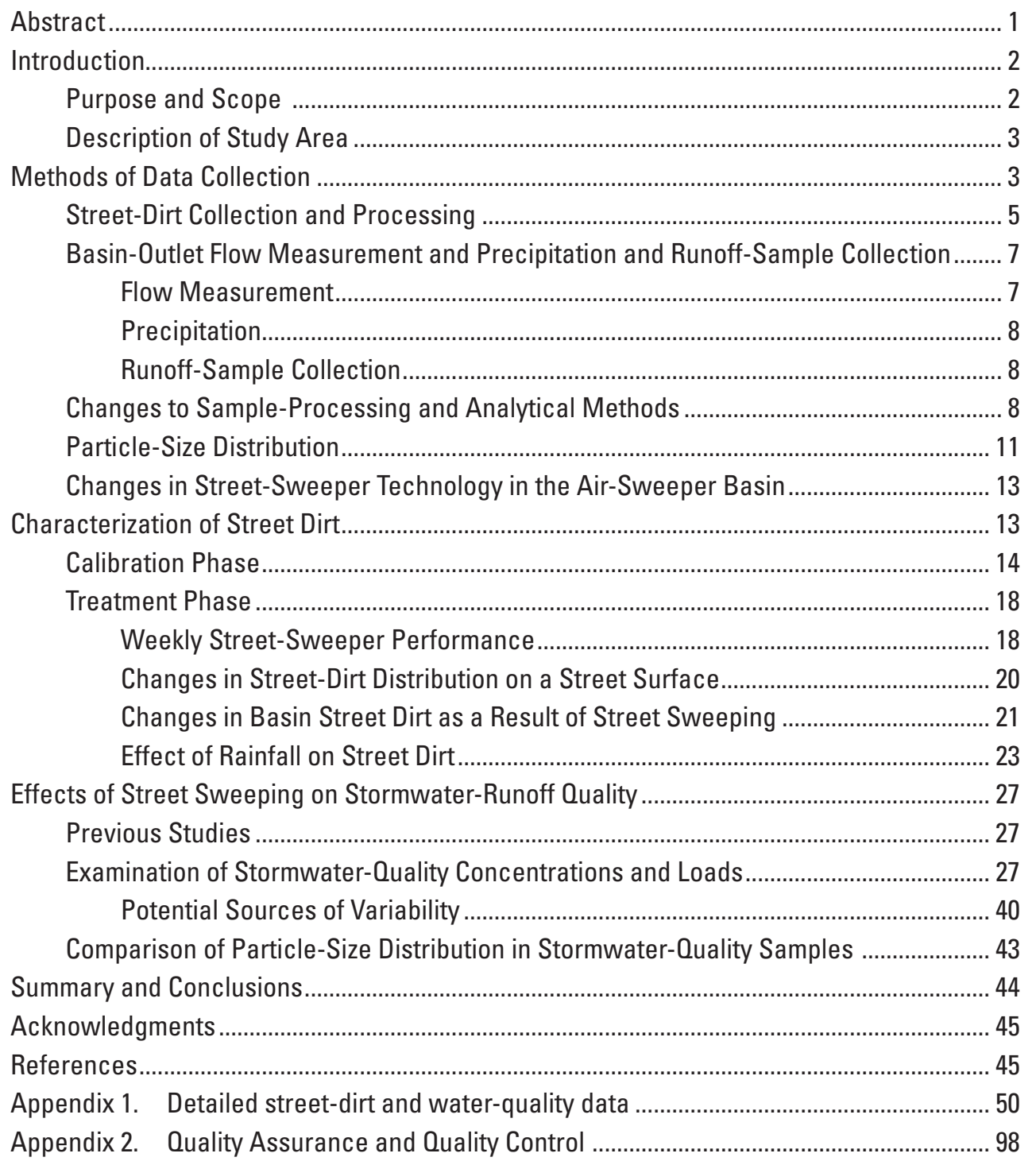




\section{Figures}

1. Map showing location of study basins and water-quality monitoring stations, Madison, Wis.

2-3. Photographs showing:

2. Demonstration of equipment used to collect street dirt samples .... 5

3. A vacuumed strip leaves a visible trail indicating the degree of available street dirt.

4-5. Graphs showing:

4. Verification of regression equations used to predict water levels in the control basin during periods when the water level sensor was faulty

5. Typical subsample coverage of hydrograph

6-7. Boxplots showing:

6. Average weekly street-dirt yields in the control and test basins during the calibration phase

7. Influence of spring (April-May) street-dirt yield on total basin averages...... 16

8-10. Graphs showing:

8. Average basin street-dirt yield categorized by season in the control and test basins during the 2002 calibration phase.

9. Paired-basin relation between the control and test basins during the calibration phase

10. Average changes in weekly street-dirt yield as a function of particle size for three street-sweeping treatments in Madison, Wis.

11. Diagram showing location of sub-sampling strips to determine the distribution of street-dirt yield across a street

12. Graph showing street sweeper removal capabilities as a function of initial street-dirt yield.

13. Boxplot showing average weekly street-dirt yield during the treatment phase .... 22

14a-c. Graphs showing:

14a. Response of average weekly street-dirt yield to street sweeping in the air-sweeper basin

14b. Response of average weekly street-dirt yield to street sweeping in the high-frequency broom basin.

14c. Response of average weekly street-dirt yield to street sweeping in the low-frequency broom basin

15-16. Boxplots showing:

15. Comparison of street-dirt yields in the control basin, 2002-2004

16. Control and test basin water-quality loads for selected constituents during calibration and treatment phases

17. Graph showing estimated number of samples required to result in statistically relevant conclusions in a paired-basin study 
18-22. Photographs showing:

18. Examples of lawn-maintenance practices in two study basins 41

19. Residue from sand applied to a street surface to provide traction for vehicles .

20. Accumulation of sediment in the junction of a manhole with the storm-sewer conveyance system.

21. Contribution of sediment to a street from a residential lawn.

22. Water-quality sample intake located at a fixed point along the storm-sewer wall

\section{Tables}

1. Physical characteristics of the control and test basins selected for the Madison, Wis., street-sweeping study

2. Characteristics of streets sampled in the control and test basins ............................ 6

3. Constituents analyzed in samples of runoff at the air sweeper, high-frequency broom, and control study basins

4. Process of including the mass of sediment wet-sieved from a wholestormwater sample back into the distribution of particle sizes in a subsample..... 12

5. Schedule for street-dirt sample collection. 14

6. Comparison of street-dirt yields, measured during the no-sweeping phase of this study in Madison, Wis., to those for other residential streets in the United States

7. Summary statistics of average basin street-dirt change for the regenerativeair, vacuum-assist, and high-frequency mechanical broom sweepers during the treatment phase.

8. Distribution of street-dirt yield before and after street sweeping on a single street in the air-sweeper basin, April to June 2005.

9. Distribution of particles measured from street surfaces in the control and test basins during the calibration and treatment phases

10. Summary statistics of average basin street-dirt yields for the control and test basins during calibration and treatment phases.

11a. Summary of water-quality concentrations in storm water from the control and air-sweeper basins during calibration and treatment phases

11b. Summary of water-quality concentrations in storm-water from the control and high-frequency broom basins during calibration and treatment phases.

12a. Summary of loads in the control and air-sweeper basins during calibration and treatment phases.

12b. Summary of loads in the control and high-frequency broom basins during calibration and treatment phases

13. Probabilities that there is no difference in storm-runoff loads between calibration and treatment phases for the regenerative-air, vacuum-assist, and high-frequency broom sweepers.

14. Coefficient of variation for constituent loads measured in stormwater from the control and test basins during the calibration and treatment phases

15. Average percent distribution, by mass, of particle sizes for water-quality samples collected in the control and test basins during calibration and treatment phases 


\section{Appendixes}

Appendix 1. Detailed street-dirt and water-quality data

1-1. Control basin street-dirt yield, in pounds per curb-mile, separated

by particle size

1-2. Air-sweeper basin street-dirt yield, in pounds per curb-mile, separated

by particle size .

1-3. High-frequency broom basin street-dirt yield, in pounds per curb-mile, separated by particle size

1-4. Low-frequency broom basin street-dirt yield, in pounds per curb-mile,

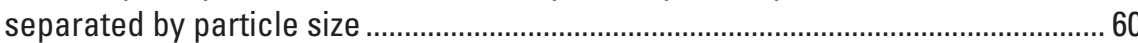

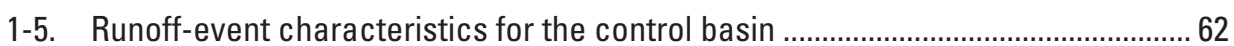

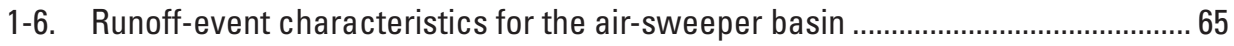

1-7. Runoff-event characteristics for the high-frequency broom basin ........................ 70

1-8a. Constituent event mean concentrations measured at the control and air-sweeper basin outlets during the calibration phase

1-8b. Constituent event mean concentrations measured at the control and high-frequency broom basin outlets during the calibration phase

1-8c. Constituent event mean concentrations measured at the control and air-sweeper basin outlets during the treatment phase.

1-8d. Constituent event mean concentrations measured at the control and

high-frequency broom basin outlets during the treatment phase.

1-9a. Constituent event mean loads measured at the control and air-sweeper basin outlets during the calibration phase...

1-9b. Constituent event mean loads measured at the control and high-frequency broom basin outlets during the calibration phase

1-9c. Constituent event mean loads measured at the control and air-sweeper basin outlets during the treatment phase.

1-9d. Constituent event mean loads measured at the control and high-frequency broom basin outlets during the treatment phase.

Appendix 2. Quality assurance and quality control

2-1. Results of blank-sample analyses 99

2-2. Results of replicate-sample analyses 


\section{Conversion Factors}

\begin{tabular}{|c|c|c|}
\hline Multiply & By & To obtain \\
\hline \multicolumn{3}{|c|}{ Length } \\
\hline inch (in.) & 25.4 & millimeter $(\mathrm{mm})$ \\
\hline foot $(\mathrm{ft})$ & 0.3048 & meter $(\mathrm{m})$ \\
\hline mile (mi) & 1.609 & kilometer (km) \\
\hline millimeter $(\mathrm{mm})$ & 0.03937 & inch (in.) \\
\hline \multicolumn{3}{|c|}{ Area } \\
\hline acre & 4,047 & square meter $\left(\mathrm{m}^{2}\right)$ \\
\hline acre & 0.4047 & hectare (ha) \\
\hline \multicolumn{3}{|c|}{ Volume } \\
\hline gallon (gal) & 3.785 & liter (L) \\
\hline gallon (gal) & 0.003785 & cubic meter $\left(\mathrm{m}^{3}\right)$ \\
\hline cubic foot $\left(\mathrm{ft}^{3}\right)$ & 0.02832 & cubic meter $\left(\mathrm{m}^{3}\right)$ \\
\hline liter $(\mathrm{L})$ & 0.2642 & gallon (gal) \\
\hline \multicolumn{3}{|c|}{ Flow rate } \\
\hline foot per second (ft/s) & 0.3048 & meter per second $(\mathrm{m} / \mathrm{s})$ \\
\hline cubic foot per second $\left(\mathrm{ft}^{3} / \mathrm{s}\right)$ & 0.02832 & cubic meter per second $\left(\mathrm{m}^{3} / \mathrm{s}\right)$ \\
\hline gallon per minute (gal/min) & 0.06309 & liter per second $(\mathrm{L} / \mathrm{s})$ \\
\hline gallon per day (gal/d) & 0.003785 & cubic meter per day $\left(\mathrm{m}^{3} / \mathrm{d}\right)$ \\
\hline \multicolumn{3}{|c|}{ Mass } \\
\hline pound, avoirdupois (lb) & 0.4536 & kilogram (kg) \\
\hline ton per day (ton/d) & 0.9072 & metric ton per day \\
\hline pounds per curb-mile & 3.55 & kilograms per curb-kilometer \\
\hline $\operatorname{gram}(\mathrm{g})$ & 0.03527 & ounce, avoirdupois (oz) \\
\hline kilogram (kg) & 2.205 & pound avoirdupois (lb) \\
\hline
\end{tabular}

Temperature in degrees Celsius $\left({ }^{\circ} \mathrm{C}\right)$ may be converted to degrees Fahrenheit $\left({ }^{\circ} \mathrm{F}\right)$ as follows: ${ }^{\circ} \mathrm{F}=\left(1.8 \times{ }^{\circ} \mathrm{C}\right)+32$

Concentrations of constituents in water are given either in milligrams per liter $(\mathrm{mg} / \mathrm{L})$ or micrograms per liter $(\mu \mathrm{g} / \mathrm{L})$.

Particle sizes of sediment are given in micrometers $(\mu \mathrm{m})$. A micrometer is one-thousandth of a millimeter. 


\title{
Evaluation of Street Sweeping as a Stormwater- Quality-Management Tool in Three Residential Basins in Madison, Wisconsin
}

\author{
By William R. Selbig and Roger T. Bannerman
}

\begin{abstract}
Recent technological improvements have increased the ability of street sweepers to remove sediment and other debris from street surfaces; the effect of these technological advancements on stormwater quality is largely unknown. The U.S. Geological Survey, in cooperation with the City of Madison and the Wisconsin Department of Natural Resources, evaluated three street-sweeper technologies from 2002 through 2006. Regenerative-air, vacuum-assist, and mechanical-broom street sweepers were operated on a frequency of once per week (high frequency) in separate residential basins in Madison, Wis., to measure each sweeper's ability to not only reduce street-dirt yield but also improve the quality of stormwater runoff. A second mechanical-broom sweeper operating on a frequency of once per month (low frequency) was also evaluated to measure reductions in street-dirt yield only. A paired-basin study design was used to compare street-dirt and stormwater-quality samples during a calibration (no sweeping) and a treatment period (weekly sweeping). The basis of this paired-basin approach is that the relation between paired street-dirt and stormwater-quality loads for the control and tests basins is constant until a major change is made at one of the basins. At that time, a new relation will develop. Changes in either street-dirt and/or stormwater quality as a result of street sweeping could then be quantified by use of statistical tests.
\end{abstract}

Street-dirt samples collected weekly during the calibration period and twice per week during the treatment period, once before and once after sweeping, were dried and separated into seven particle-size fractions ranging from less than 63 micrometers to greater than 2 millimeters. Street-dirt yield evaluation was based on a computed mass per unit length of pounds per curb-mile. An analysis of covariance was used to measure the significance of the effect of street sweeping at the end of the treatment period and to quantify any reduction in street-dirt yield. Both the regenerative-air and vacuum-assist sweepers produced reductions in street-dirt yield at the 5-percent significance level. Street-dirt yield was reduced by an average of 76, 63, and 20 percent in the regenerative-air, vacuum-assist, and high-frequency broom basins, respectively. The low-frequency broom basin showed no significant reductions in street-dirt yield. Sand-size particles (greater than 63 micrometers) recorded the greatest overall reduction. Street-sweeper pickup efficiency was determined by computing the difference between weekly street-dirt yields before and after sweeping cleaning. The regenerative-air and vacuum-assist sweepers had similar pickup efficiencies of 25 and 30 percent, respectively. The mechanical broom sweeper operating at high frequency was considerably less efficient, removing an average of 5 percent of street-dirt yield.

The effects of street sweeping on stormwater quality were evaluated by use of statistical tests to compare event mean concentrations and loads computed for individual storms at the control and test basins. Loads were computed by multiplying the event mean concentrations by storm-runoff volumes. Only ammonia-nitrogen for the test basin with the vacuum-assist sweeper showed significant load increases over the control basin, at the 10-percent significance level, of 63 percent. Difficulty in detecting significant changes in constituent stormwater-quality loads could be due, in part, to the large amount of variability in the data. Coefficients of variation for the majority of constituent loads were greater than 1, indicating substantial variability. The ability to detect changes in constituent stormwater-quality loads was likely hampered by an inadequate number of samples in the data set. However, sediment transport in the storm-sewer pipe, sediment washing onto the street from other source areas, winter 
sand application, and sampling challenges were additional sources of variability within each study basin and may have increased the difficulty in evaluating street sweeping as a stormwater-quality-management tool.

\section{Introduction}

The Wisconsin Department of Natural Resources (WDNR) has promulgated a series of stormwater performance standards that attempt to mitigate both water-quantity and water-quality impacts associated with stormwater runoff (Wisconsin Administrative Code NR 151, 2002). Performance standards for established urban areas will require qualifying cities to reduce the annual total suspended solids (TSS) load by 40 percent. The City of Madison, along with more than 200 other Wisconsin cities, will be required to meet these performance standards by the year 2013 as part fulfillment of their U.S. Environmental Protection Agency National Pollution Discharge Elimination System (NPDES) Phase II permits.

Previous studies have indicated that runoff from street surfaces is a major contributor of constituents to receiving waters (Sartor and Boyd, 1972; Pitt and Amy, 1973; Amy and others, 1974; Waschbusch and others, 1999). Particulate and dissolved solids and organic and inorganic compounds resulting from vehicular wear and emissions, pavement degradation, maintenance, atmospheric deposition, and littering are commonly associated with urban drainage from paved areas (Sansalone and others, 1998). Although several structural best management practices (BMPs) have been designed to mitigate these constituents, most are only effective once constituents have already become entrained in urban runoff. Selection of one or more BMPs to address constituents in urban runoff may be limited by available space, existing infrastructure, and maintenance (Breault and others, 2005). One nonstructural way to control the quality of roadway or parking lot runoff is to use street sweeping as a means to remove constituents before they become entrained in runoff. Instead of facing the potentially high cost of installing and maintaining structural stormwater-treatment practices, street sweeping offers the promise of simply modifying an existing program to achieve stormwater-quality goals.

Like many other cities around the Nation, the City of Madison has limited open space available to construct new structural BMPs. The possibility of retrofitting existing areas remains an option for environmental managers, but costs may be prohibitive. The city already owns and operates nine street sweepers (A. Schumacher, City of Madi- son, written commun., 2007). Eight of the sweepers use a mechanical broom as the principal mechanism to clean a street. This technology has been around for decades and is used primarily for spring cleanup, trash removal, and fall leaf pickup. In addition to mechanical-broom sweepers, the city also owns and operates one street sweeper using vacuum-assist technology. The improved technology incorporated into these street sweepers has not been adequately field tested, especially when considering their effect on stormwater quality. In order to understand how best to protect the many lakes and rivers that surround the City of Madison, city officials were interested in evaluating the effectiveness of street sweeping as a stormwater-qualitymanagement option.

The focus of the study described in this report was to characterize the effectiveness of street sweeping at reducing street-dirt yield, as well as evaluating street sweeping's effect on stormwater quality. Few studies have quantified the capabilities of street sweepers with improved technologies, such as regenerative-air or vacuum-assisted brooms, to remove street dirt. Even fewer studies have examined the benefits of street sweeping on stormwater quality. To augment previously collected data sets that characterize various street-sweeper technologies and to understand the stormwater-quality benefits from these sweepers, the U.S. Geological Survey, in cooperation with the City of Madison and the Wisconsin Department of Natural Resources, collected street-dirt from four residential basins in Madison. Stormwater-quality samples also were collected in three of the four basins. Samples were used to calculate loads during a calibration (no sweeping) and treatment (sweeping) phase. Relations were established between the loads for the control and test basins. These relations were tested for changes between the calibration and treatment periods. This study supports an ongoing effort to identify existing and new methods to reduce nopoint-source pollution from urban areas.

\section{Purpose and Scope}

This report describes the methods used in and the results from the City of Madison street-sweeping study. An analysis of potential street dirt and stormwater-quality-constituent load reductions are presented to provide an estimate of stormwater-quality benefits from street sweeping. A paired-basin design (Clausen and Spooner, 1993) was used to help evaluate the effectiveness of various street-sweeping programs at reducing street-dirt yields and improving stormwater quality in urban runoff. 
Four basins were chosen to represent various sweeping scenarios. Specifically, this study examined the street-dirt-removal efficiencies and subsequent changes in stormwater-quality loads from a regenerative-air, vacuumassisted, and mechanical-broom street sweeper operated on a frequency of once per week (high frequency). An additional mechanical-broom sweeper operating on a frequency of approximately once per month (low frequency) was also evaluated for street-dirt removal only. The study period began in 2002 and ended in 2006.

Concentrations of 26 constituents including particulate and dissolved solids, inorganic compounds, and trace metals in stormwater-runoff samples were used to compute storm loads for each constituent at the basin outfall. Reduction in constituent loads by use of different sweeper technologies was estimated based on differences between calibration and treatment phases. In addition to stormwater quality and quantity, street-dirt yields were characterized before and after street sweepers entered each basin.

\section{Description of Study Area}

Madison, Wis. has a population of 208,054 (based on the 2000 census). The climate is typical of interior North America, with a large annual temperature range and frequent short-period temperature changes. Nearly 60 percent of the 32.95 inches of average annual precipitation falls in the months of May through September (National Climatic Data Center, 2003). The study area is near the southwest limits of the city in a predominantly single-family residential setting (fig. 1). Study basins were within a 1-mile radius of each other to help reduce variation in storm rainfall. Selection of each basin was based on similarity in physical conditions, including basin area, land use, street condition, age of streets since last resurfacing, overhead tree canopy, topography, and lot size. Table 1 details some of the physical characteristics of each basin.

A naming convention based on the type of streetsweeper technology used was adopted to simplify discussion of each basin involved in the study. The control basin was appropriately named "control." The test basin, where a regenerative air sweeper was used (later replaced by a vacuum-assisted sweeper) is referred to as the "air-sweeper" basin. The two basins that were swept with a mechanical broom sweeper are distinguished by the frequency at which the basin was swept, "low-frequency broom" representing a frequency of approximately once per month, and "high-frequency broom" representing a frequency of once per week.
The test basins selected for this study have similar drainage areas. The drainage area for the control basin is considerably larger, nearly double that of the test basins (table 1). Land use was categorized into seven major source areas: driveways, rooftops, lawns, streets, sidewalks, parking lot, and other. Lawns and grassy areas make up the majority of each basin, ranging from 65 to 69 percent. Streets make up approximately the same area for each basin, ranging from 8 percent in the low-frequency broom basin to 13 percent in the air-sweeper basin. Both the high-frequency broom basin and the control basin include small areas that do not fit into one of the major source-area categories. A city park occupies 4 percent of the high-frequency broom basin. This area was not included in the "lawn" category because the physical processes associated with a public park may be different from those of a typical residential lawn. Similarly, the control basin includes a small community swimming pool that makes up 1 percent of basin area. Drainage of stormwater in each basin is collected into a network of storm-sewer pipes that eventually flow into Dunn's Marsh, approximately 1.0 mile southeast of the study area. Street widths within each basin typically measured 33 feet from curb to curb. Onstreet parking was minimal and considered negligible with respect to street-sweeper performance. Therefore, parking restrictions were not enforced during sweeper operation. There were no catch basins in the storm-drainage network for either the control or test basins.

The control and test basins, with the exception of the low-frequency broom basin, were equipped with monitoring stations to measure stormwater runoff and collect stormwater-quality data. The locations of the monitoring stations are identified in figure 1.

\section{Methods of Data Collection}

This study collected, characterized, and interpreted data derived from street-dirt and stormwater-quality samples collected in the four residential basins. Street-dirt data consists of street-dirt yields reported in units of mass per unit length. Constituent concentrations and loads were determined from data collected from a storm-sewer pipe near the basin outlet. Quality assurance and quality control methods and results can be found in appendix 2 . 

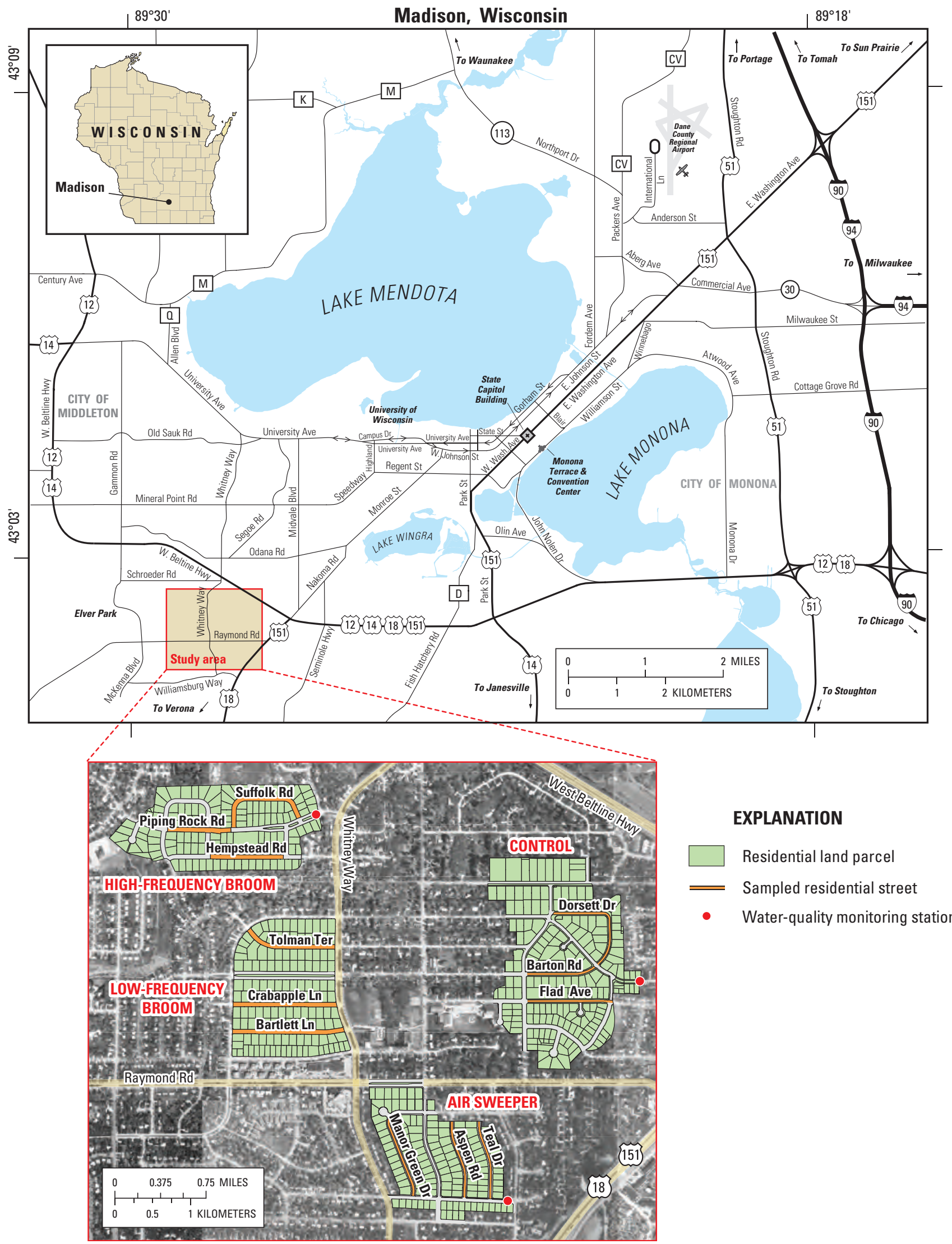

EXPLANATION

Residential land parcel

Sampled residential street

- Water-quality monitoring station

Figure 1. Location of study basins and water-quality monitoring stations, Madison, Wis. 


\section{Street-Dirt Collection and Processing}

Street-dirt particulate sampling consisted of collecting available material from street surfaces within the designated test and control basins. Three streets within each basin were selected to represent overall basin street-dirt characteristics. Individual streets that were sampled are identified in figure 1 and described in table 2. Predetermined numbers of subsamples were collected at random locations across each street width and were later combined to make up a single street-dirt sample.

The equipment and sampling procedures were slightly modified from those described by Pitt (1979) and Bannerman and others (1983). Subsamples were collected with a single 9-gallon, stainless steel, wet/dry vacuum rated at 92 cubic feet per minute maximum air flow. The vacuum head was connected to a 25 -foot black neoprene, wire-reinforced hose, which was in turn connected to a wand and 6-inch-wide aluminum nozzle. The vacuum and generator were transported by a trailer-mounted cargo carrier on a USGS field vehicle. Figure 2 shows the equipment used during street-dirt sample collection.

Samples were obtained by vacuuming several narrow strips across the street width, beginning from one curb edge and moving across the street to the other curb edge

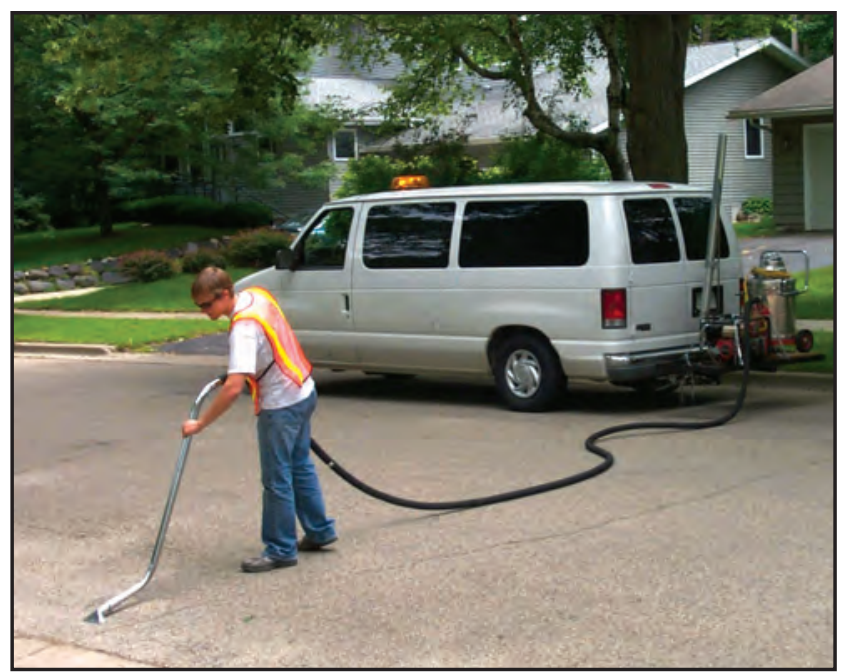

Figure 2. Demonstration of equipment used to collect street dirt samples.

(fig. 2). Initially, 10 subsamples, consisting of a single curb-to-curb vacuum pass, were collected and weighed individually at each street selected in the study to determine the variability in street-dirt yields. The variability was then used to calculate the number of subsamples necessary per street to accurately represent a composite

Table 1. Physical characteristics of the control and test basins selected for the Madison, Wis., street-sweeping study.

[\%, percent; --, land use not present in basin; values in parentheses represent percentages of total basin area]

\begin{tabular}{lcccc}
\hline \multicolumn{1}{c}{ Characteristic } & Control & Air sweeper & $\begin{array}{c}\text { High-frequency broom } \\
\text { (weekly) }\end{array}$ & $\begin{array}{c}\text { Low-frequency broom } \\
\text { (monthly) }\end{array}$ \\
\hline Drainage area (acres) & 89.7 & 52.5 & 58.9 & 58.6 \\
Land use (acres): & & & & \\
$\quad$ Driveway & $4.5(5 \%)$ & $2.6(5 \%)$ & $2.9(5 \%)$ & $4.8(8 \%)$ \\
$\quad$ Lawns & $62.0(69 \%)$ & $34.4(66 \%)$ & $38.3(65 \%)$ & $40.7(69 \%)$ \\
$\quad$ Roofs & $10.7(12 \%)$ & $7.0(13 \%)$ & $7.3(12 \%)$ & $8.0(14 \%)$ \\
$\quad$ Sidewalks & $1.0(1 \%)$ & $1.5(3 \%)$ & $1.7(3 \%)$ & $<1.0(1 \%)$ \\
$\quad$ Streets & $10.5(12 \%)$ & $6.9(13 \%)$ & $6.6(11 \%)$ & $4.6(8 \%)$ \\
$\quad$ Parking lot & $1.0(<1 \%)$ & -- & -- & -- \\
$\quad$ Other & $1.0(1 \%)$ & -- & $2.1(4 \%)$ & -- \\
\hline Soil type & Silt loam & Silt loam & Silt loam & Silt loam \\
Average age of homes (years) & 40 & 50 & 50 & 50 \\
Years since streets last resurfaced & 15 & 15 & 15 & 15 \\
Street composition/condition & Asphalt/good & Asphalt/good & Asphalt/good & Asphalt/good \\
Street texture & Intermediate & Intermediate & Smooth/intermediate & Intermediate \\
Average slope & $1.2 \%$ & $0.8 \%$ & $2.3 \%$ & $0.9 \%$ \\
Average lot size (acres) & 0.25 & 0.25 & 0.25 & 0.25 \\
\hline
\end{tabular}


street-dirt yield. The number of subsamples, $\mathrm{N}$, was determined as follows:

$$
N=4.25 \frac{(s-1)^{2}}{(r \bar{y})^{2}}, \quad \text { (Hansen and others, 1984) }
$$

where

$N$ is the estimated number of subsamples required to estimate residential street-dirt yield;

$\bar{y}$ is the average mass of measured subsamples;

$s$ is the standard deviation of measured subsamples' mass; and

$r$ is the allowable error.

The allowable error used for this study was 0.50 , or plus or minus 50 percent. Lower error terms were not feasible because of subsequent increases in sampling effort. For example, an error term of 25 percent would increase the number of subsamples at one particular street from 9 to 34 , making data collection cost prohibitive. A similar conclusion was reached for street-dirt data collected as part of the Nationwide Urban Runoff Program (NURP). At an allowable error of 25 percent, the number of required subsamples approached 25 (U.S. Environmental Protection Agency, 1983). Use of an allowable error of 50 percent kept the number of subsamples at or below 10 for each street in the study. To simplify the street-dirt collection effort, approximately 10 subsamples were collected at all streets selected for this study.

Each subsample was collected to represent the material that might be removed from a street surface during a heavy rainstorm. Therefore, the locations of the subsample strips were areas along each street that were not influenced by unusual loading conditions such as debris piles. Markers were painted on the curb of each street at approximately 100 -foot increments to indicate to field crews the locations of subsample strips. Even though the markers served as means to identify where to collect subsamples, they were merely visual guides and not exact locations. Therefore, each subsample was collected with appropriate discretion. This flexibility artificially reduced variability in street-dirt yields by allowing field technicians to move the location of a subsample strip in the event of an unusual loading condition, such as a leaf pile or accumulated debris.

A test was set up to examine the reproducibility of the street-dirt sample-collection procedures. Street-dirt samples were collected on consecutive days during the 2004 sample-collection year in the control basin. A paired sample t-test, used to find differences between paired data sets, evaluated whether street dirt from the first sample set was different from that in the second sample set. Results of the test revealed no difference between the first and second collections of street-dirt samples at the 95-percent confidence level. Because the street-dirt samples showed good precision, any sources of variability in street-dirt yields were not likely caused by sample-collection techniques.

Because of differences in street textures, care was taken to ensure a proper rate at which the nozzle was moved across the street. A rough, pitted street surface required a slower rate than a smooth street did. Additionally, a greater amount of particulate material on a street

Table 2. Characteristics of streets sampled in the control and test basins.

\begin{tabular}{llrcc}
\hline \multicolumn{1}{c}{ Basin } & Street name & $\begin{array}{c}\text { Length } \\
\text { (feet) }\end{array}$ & $\begin{array}{c}\text { Width } \\
\text { (feet) }\end{array}$ & $\begin{array}{c}\text { Average annual weekday traffic } \\
\text { (cars per day) }\end{array}$ \\
\hline Control & Barton & 936 & 33 & 226 \\
& Flad & 1,077 & 33 & 294 \\
& Dorsett & 1,008 & 33 & 151 \\
\hline Air sweeper & Manor Green & 1,097 & 33 & 274 \\
& Aspen & 1,117 & 33 & 250 \\
& Teal & 1,129 & 33 & 207 \\
\hline Low-frequency broom & Tolman & 1,230 & 33 & 230 \\
(monthly) & Crabapple & 1,356 & 33 & 270 \\
& Bartlett & 1,474 & 33 & 280 \\
\hline High-frequency broom & Suffolk & 1,286 & 33 & 200 \\
(weekly) & Piping Rock & 850 & 33 & 1,236 \\
& Hempstead & 980 & 33 & 249 \\
\hline
\end{tabular}




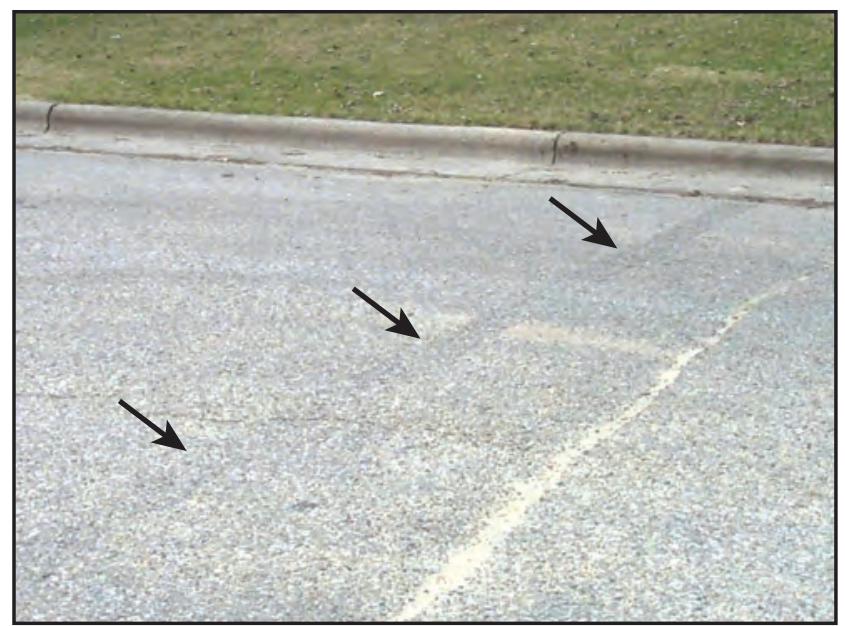

Figure 3. A vacuumed strip leaves a visible trail indicating the degree of available street dirt.

surface required more time for adequate sample collection. The average rate used during the course of this study was approximately 1 foot per second. However, confirmation of an adequate rate to move the nozzle came from both visual and audible observation of the street surface itself. The operator of the sample-collection wand was able not only to see the material removed from the street surface but could also hear particles moving through the vacuum hose. The operator would adjust the rate to ensure that as much of the stored dirt was removed as possible. At times, a visible trail was left behind where the nozzle had removed available street dirt (fig. 3). During the fall, leaves would often clog the vacuum nozzle; consequently, an effort was made to physically pick up by hand any leaves or other detritus that was within the 6-inch-wide swath. All material was later added to the vacuum collection bag. Ultimately, when the accumulating amount of vegetative material on the street made it impractical to collect such a large volume of leaves, street-dirt collection was suspended until the following spring.

Once all subsamples for a particular street were collected, the vacuum was shut off and disassembled. A cloth filter inside the vacuum head was first shaken vigorously inside the vacuum canister and then was carefully brushed with a soft broom to remove most of the filtered material. After the dust inside the vacuum canister settled for a few seconds, all contents were transferred into a plastic container and sealed. On days when winds were gusty, some of the dust captured by the filter became airborne and was lost. Measures were taken to minimize the loss by moving the filter into an area protected from the wind.

All street-dirt samples were taken back to the USGS Wisconsin Water Science Center's Middleton Field Office and dried overnight in an oven at $105^{\circ} \mathrm{C}$. The samples were then weighed and separated into eight different fractions including large detritus and particles in the ranges (micrometers) of: greater than 2,000; 1,000-2,000; 500-1,000; 250-500; 125-250; 63-125; and less than 63. Results of individual street-dirt yields for each basin broken down by particle size can be found in tables 1-1 through 1-4 in appendix 1.

\section{Basin-Outlet Flow Measurement and Precipitation and Runoff-Sample Collection}

Stormwater runoff was measured and collected at the basin outlets in the control, air-sweeper, and highfrequency broom basins. Locations of the monitoring stations are shown in figure 1. Each monitoring station was equipped with automated stormwater-quality samplers and instruments to measure water level and velocity. Measurement, control, and storage of data were done by way of electronic dataloggers. Data were automatically retrieved twice daily with telephone modems. In both the airsweeper and high-frequency broom basins, precipitation data were collected by use of a tipping-bucket rain gage calibrated to $0.01 \mathrm{inch}$. Descriptive statistics for sampled runoff events in the control and test basins are detailed in tables 1-5 through 1-7 in appendix 1.

\section{Flow Measurement}

Monitoring stations measured flow and collected samples at the basin outlet from a 3.50-foot-diameter circular storm sewer at the control and air-sweeper basin and a 38 x 60-inch elliptical storm sewer in the high-frequency broom basin. A probe with two different sensor systems was mounted to the bottom of each pipe. Each probe contained a pressure transducer to measure water level and a pair of ultrasonic transducers to measure velocity. A fifth-order polynomial was used to convert water level into cross-sectional area for each pipe configuration. Instantaneous pipe discharge was then computed by multiplying the cross-sectional area of the pipe by the associated mean velocity. Storm-runoff volumes were computed by summing the 1-minute-interval instantaneous discharge during the sampled storm. When water level at the sensor was less than 1 inch, flow calculations were not considered reliable because the sensor itself was not fully submersed. Given the large diameter of the drainage pipe at each monitoring station, all flows occurring at less than 1-inch depth were considered insignificant to the overall event volume. 
The area-velocity probe at the control-basin outlet frequently produced periods of unreliable water-level data during June-September, 2002 and April-September, 2003. Steps were taken to obtain the most accurate flow estimates possible for this basin. Because of the proximity of the control and air-sweeper basin and similarities in pipe diameter, storm-runoff hydrographs at each basin outlet mirrored each other quite closely when equipment at both stations was functional. A polynomial regression equation was developed for these periods over a wide range of water levels. The following equations were used to adjust questionable water-level data at the control-basin outlet given reliable water-level data from the air-sweeper basin:

\begin{tabular}{cc}
\hline $\begin{array}{c}\text { Gage height } \\
\text { (feet) }\end{array}$ & Equation \\
\hline $0.0-0.20$ & $\mathrm{~S}_{\mathrm{c}}=0.00196+1.01 \mathrm{~S}_{\mathrm{a}}+3.72 \mathrm{~S}_{\mathrm{a}}{ }^{2}+$ \\
& $19.3 \mathrm{~S}_{\mathrm{a}}{ }^{3}-125 \mathrm{~S}_{\mathrm{a}}{ }^{4}$ \\
$0.20-0.50$ & $\mathrm{~S}_{\mathrm{c}}=-0.0108+1.72 \mathrm{~S}_{\mathrm{a}}+1.05 \mathrm{~S}_{\mathrm{a}}{ }^{2}-$ \\
& $8.63 \mathrm{~S}_{\mathrm{a}}{ }^{3}+8.77 \mathrm{~S}_{\mathrm{a}}{ }^{4}$ \\
& $\mathrm{~S}_{\mathrm{c}}=0.427-0.381 \mathrm{~S}_{\mathrm{a}}+2.02 \mathrm{~S}_{\mathrm{a}}{ }^{2}-$ \\
$0.50-1.0$ & $1.66 \mathrm{~S}_{\mathrm{a}}{ }^{3}+0.738 \mathrm{~S}_{\mathrm{a}}{ }^{4}$ \\
& \\
greater than 1.0 & $\mathrm{~S}_{\mathrm{c}}=0.267+0.984 \mathrm{~S}_{\mathrm{a}}-0.196 \mathrm{~S}_{\mathrm{a}}{ }^{2}$ \\
\hline
\end{tabular}

where

$\mathrm{S}_{\mathrm{c}}$ is the gage height, in feet, at the control basin; and

$\mathrm{S}_{\mathrm{a}}$ is the gage height, in feet, at the air-sweeper basin.

The regression equations were verified by applying them to periods of runoff when the control-basin waterlevel sensor was working properly. Figure 4 represents an event hydrograph comparing original water levels and those predicted by use of the regressions for the control basin during periods when the water levels were measured correctly.

\section{Precipitation}

Continuous precipitation data were collected by use of two tipping-bucket rain gages, one each in the airsweeper and high-frequency broom basins. Although these rain gages were not designed to measure snowfall, there were several runoff events during winter months where precipitation was in the form of rain instead of snow. Precipitation data were compiled and statistical summaries were computed for both rain-gage locations. Precipitation data measured in the air-sweeper and the high-frequency broom basin are presented in tables 1-6 and 1-7, respectively, in appendix 1.

\section{Runoff-Sample Collection}

Sample collection was activated by a rise in water level in the pipe during a storm. Once the water-level threshold was exceeded, typically a depth of $0.15 \mathrm{ft}$ from the pipe floor, the volume of water passing the station was measured and accumulated at 1-minute increments until a volumetric threshold was reached. At that point, the sampler collected a discrete water sample and the volumetric counter was reset. The process was repeated until the water level receded below the threshold. The Teflon-lined intake nozzle of the sampler orifice was approximately 1 inch above the pipe floor. One liter sub-samples were transferred through the Teflon-lined sample tubing into a 10-liter glass jar refrigerated at 4 degrees Celsius.

These flow-weighted samples were collected and composited into a single water sample, then split and processed for analysis. A Teflon-coated, stainless steel churn splitter was used to composite and split samples into smaller plastic bottles for chemical and physical analysis. Processed samples were kept in a refrigerator until picked up, usually within 48 hours after runoff cessation, by City of Madison Department of Public Health staff for determination of concentrations of the constituents listed in table 3. Because each discrete sample was composited into a single event sample, the resulting concentration represents the event mean concentration (EMC). An example of flow-weighted sampling from a storm on October 24, 2004, is shown in figure 5 .

\section{Changes to Sample-Processing and Analytical Methods}

Previous studies have demonstrated that use of both churn splitting and aliquots can introduce significant bias and (or) poor precision into sediment and sedimentassociated constituent-concentration results (Capel and Larson, 1996; Horowitz and others, 1997; Gray and others, 2000; Selbig and others, 2007). Much of the variability can be attributed to the presence of entrained sediment in urban runoff whose size can have a large mass fraction in the sand-size range (Horwatich and others, 2004). During the early stages of this study, whole-stormwater samples collected from the control and test basins were found to frequently contain suspended-sediment concentrations exceeding 1,000 milligrams per liter (appendix tables 1-8a and 1-8b), with a large percentage of sediment particles larger than 250 micrometers (table 15). 


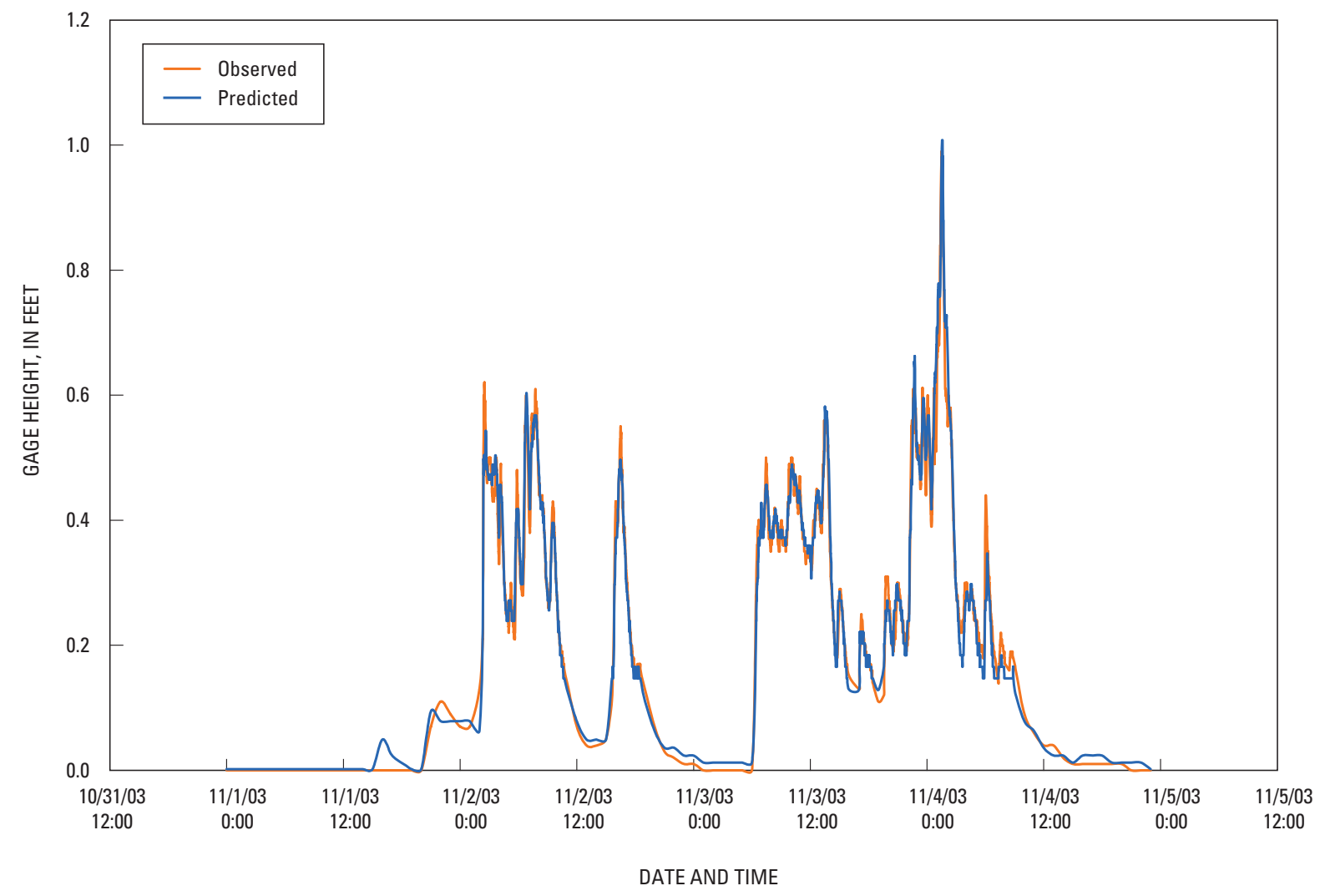

Figure 4. Verification of regression equations used to predict water levels in the control basin during periods when the water level sensor was faulty.

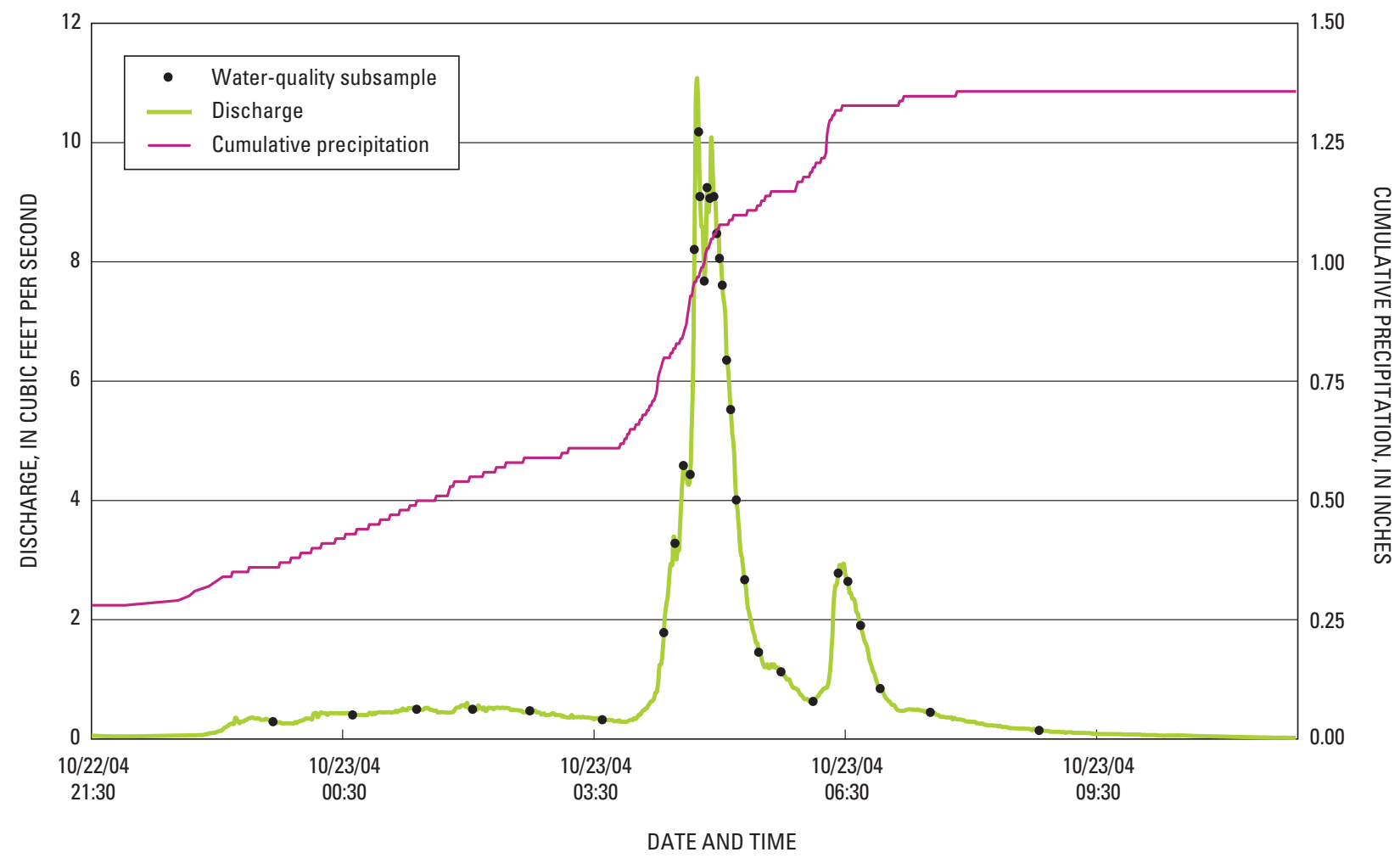

Figure 5. Typical subsample coverage of hydrograph. 
Table 3. Constituents analyzed in samples of runoff at the air sweeper, high-frequency broom, and control study basins.

[N, nitrogen; MDPH, Madison Department of Public Health; USGS-ISL, U.S. Geological Survey Iowa Sediment Laboratory; WSLH, Wisconsin State Laboratory of Hygiene; USEPA, U.S. Environmental Protection Agency (U.S. Environmental Protection Agency, 1979); SM, Standard Methods (American Public Health Association and others, 1989)]

\begin{tabular}{|c|c|c|}
\hline Constituent & Laboratory & Method or reference \\
\hline Dissolved cadmium & MDPH & USEPA 200.7 \\
\hline Total cadmium & MDPH & USEPA 200.7 \\
\hline Total calcium & MDPH & USEPA 200.7 \\
\hline Dissolved copper & MDPH & USEPA 200.7 \\
\hline Total copper & MDPH & USEPA 200.7 \\
\hline Dissolved lead & MDPH & USEPA 200.7 \\
\hline Total lead & MDPH & USEPA 200.7 \\
\hline Total magnesium & MDPH & USEPA 200.7 \\
\hline Total phosphorus & MDPH & USEPA 200.7 \\
\hline Dissolved zinc & MDPH & USEPA 200.7 \\
\hline Total zinc & MDPH & USEPA 200.7 \\
\hline Total alkalinity & MDPH & USEPA 310.2 \\
\hline Dissolved chloride & MDPH & USEPA 300.0 \\
\hline Conductivity & MDPH & SM 2510 \\
\hline Total hardness & MDPH & SM 2340B \\
\hline Ammonia $\mathrm{N}$ & MDPH & USEPA 350.1 \\
\hline Total Kjeldahl N & MDPH & USEPA 351.2 \\
\hline Dissolved $\mathrm{N}_{2}+\mathrm{N}_{3}$ & MDPH & USEPA 300.0 \\
\hline Dissolved nitrate, as $\mathrm{N}$ & MDPH & USEPA 300.0 \\
\hline Dissolved nitrite, as $\mathrm{N}$ & MDPH & USEPA 300.0 \\
\hline Orthophosphorus & MDPH & USEPA 365.1 \\
\hline $\mathrm{pH}$ & MDPH & SM 4500-H \\
\hline Total solids & MDPH & SM 2540B \\
\hline Total dissolved solids & MDPH & SM 2540C \\
\hline Total suspended solids & MDPH & SM 2540D \\
\hline Suspended sediment & $\begin{array}{l}\text { MDPH, } \\
\text { USGS-ISL }\end{array}$ & ASTM D3977-97 \\
\hline \multicolumn{3}{|c|}{ Particle-size analyses } \\
\hline Sand-silt split & USGS-ISL & Guy (1969) \\
\hline Visual accumulation tube & USGS-ISL & Guy (1969) \\
\hline Sedigraph & USGS-ISL & Guy (1969) \\
\hline Laser diffraction & WSLH & Burton and Pitt (2002) \\
\hline Wet-sieve & WSLH & Burton and Pitt (2002) \\
\hline Microfiltration & WSLH & Burton and Pitt (2002) \\
\hline
\end{tabular}


In order to reduce the bias and improve precision of stormwater constituent-concentration data, sand-size particles were physically removed from the whole-stormwater sample by wet-sieving and were analyzed as a solid sample. The remaining filtrate was analyzed separately as an aqueous sample. Typically, sediment in a whole-stormwater sample was separated into one or more of the following particle-size ranges: $125-250,250-500$, and greater than 500 micrometers using nylon sieves. The methods used to wet-sieve a whole-stormwater sample, as well as the analytical techniques used to detect the presence of trace metals on resulting sieved solids, are described by Selbig and others (2007). These new methods were adopted as part of this study in May 2004.

Concentrations of some chemical constituents may have been compromised because of physical separation of sand-size particles during the wet-sieving process. Some of the constituents, such as total Kjeldahl nitrogen, are not quantifiable from a solid-phase sediment sample. Other constituents are affected because of the method by which concentrations are determined in the analytical laboratory. For example, sediment removed from a whole-water sample by wet-sieving will no longer be available when determining constituent concentrations from the aqueous phase of the sample. Therefore, total suspended solids cannot be adequately quantified because it is based on the dry weight of sediment from a known volume of a subsample of the original. Of those constituents listed in table 3, total solids, total suspended solids, and total Kjeldahl nitrogen were not considered reliable and therefore were eliminated from statistical interpretation.

\section{Particle-Size Distribution}

Analysis of particle sizes in stormwater-quality samples was done by one of three methods, depending on the amount of material available in the sample container. The first level of particle-size definition was a "sand/silt split," which was used to determine the percentage of sediment, by mass, with a diameter greater than 63 micrometers (defined as sand) and less than 63 micrometers (defined as silt). If a sufficient quantity of sediment was available in the sample, a visual-accumulation (VA) tube analysis was used to further derive the percentage of sediment, by mass, with diameters less than 1,000, 500, 250, 125, and 63 micrometers (Guy, 1969). Often, the amount of material was insufficient for the VA tube analysis. For this reason, an alternative method described by Burton and Pitt (2002) was used to define the distribution of particles in a runoff sample. The new method, adopted as part of this study in
July 2004, builds on the concept of wet-sieving by passing a stormwater-quality sample through a series of nylonmesh sieves with mesh openings of 500, 250, 125, 63, and 32 micrometers. All material remaining on each sieve was dried and weighed to compute mass. Particles less than 32 micrometers remaining in the filtrate were further delimited into four additional particle sizes by means of laser diffraction. This process determined the percentage of sediment by mass with diameters less than $14,8,5$, and 2 micrometers.

For those whole-stormwater samples that were wetsieved during the sample-splitting process, the mass of sediment separated from the whole-stormwater sample was later included into the full particle-size distribution of the sample. The mass of sediment retained on each sieve, in milligrams, was divided by the volume of the wholestormwater sample, in liters, to obtain a concentration of sediment per each particle-size fraction. This concentration was assumed to be the same in a subsample of the wholestormwater sample had the particles not been removed by wet-sieving. The concentrations of the particles wet-sieved from the whole-stormwater sample were then included in the computation of particle-size distribution for the subsample submitted to the laboratory for particle-size analysis. Table 4 demonstrates the process of including the mass of sediment wet-sieved from the whole-stormwater sample back into the distribution of particle sizes in the subsample.

Of the 158 stormwater-quality samples analyzed for particle-size distribution, 23 samples were analyzed for sand/silt split only. Sixty of the runoff samples had sufficient sediment for the VA tube analysis. For the remaining 75 samples, a combination of wet-sieving and laser diffraction was used, resulting in a complete definition of the particle-size distribution. For all samples analyzed by either the VA tube or wet-sieving and laser-diffraction analysis, a sand/silt split was computed by subtracting the percentage of sediment, by mass, for particles less than 63 micrometers from 100. For example, if 60 percent of sediment in a runoff sample was less than 63 micrometers, then 40 percent (100 minus 60 ) would be greater than 63 micrometers. 


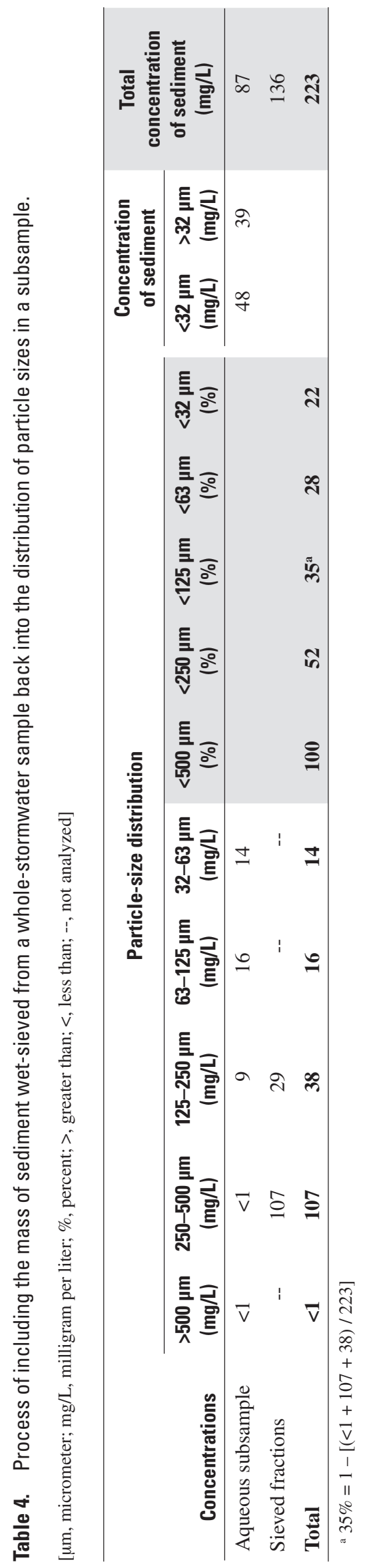




\section{Changes in Street-Sweeper Technology in the Air-Sweeper Basin}

Traditional mechanical-broom sweepers have been the workhorse for many municipalities around the country. However, previous studies indicate they are not able to effectively pick up fine accumulated sediments (U.S. Environmental Protection Agency, 1983; Pitt, 1985; Sutherland and Jelen, 1997). One of the goals of this study was to evaluate some of the advancements in street-sweeper technology that have been made over the past several years. One such technology, regenerative-air sweeping, was initially evaluated in the air-sweeper basin from April 2003 to May 2004. Regenerative-air sweepers use a mechanical broom that passes debris and sediment near the center of the vehicle chassis, where air is blown onto the pavement and immediately vacuumed back in so as to entrain and filter out accumulated sediments (Sutherland and Jelen, 1997).

The regenerative-air sweeper was replaced with a different sweeper technology starting May 26, 2004. The new vacuum-assisted sweeper was considered by industry representatives to be more effective at removing street dirt than a regenerative-air sweeper. In addition to a wire-bristled broom, the vacuum-assisted sweeper had a powerful vacuum to capture debris and sediment quickly. The vacuum was placed along the vehicle chassis such that it was able to partially overlap the area of curb swept by the broom. The new vacuum-assisted sweeper remained in the air-sweeper basin for the remainder of the study. Where appropriate, street-sweeper performance on street-dirt removal and stormwater quality in the air-sweeper basin is reported as either regenerative-air or vacuum-assist.

\section{Characterization of Street Dirt}

The quantity of street dirt and the constituents associated with it can vary widely depending on street-sweeper technology and frequency. The street-sweeper technologies most often used today are mechanical broom, regenerative air, and vacuum assisted. Performance evaluations of vacuum-assisted and regenerative-air sweepers appear mostly in trade journals and are rarely documented in peerreviewed literature (Zarriello and others, 2002). Mechanical-broom sweepers were extensively tested during the 1970s and 1980s as part of the National Urban Runoff Program (NURP); those studies concluded that mechanical-broom sweepers removed only coarser particles and did not result in any stormwater-quality benefit (Athayde and others, 1983). This study examined the removal efficiencies of these three most common street-sweeper technologies. The regenerative-air and vacuum-assisted sweepers were operated on a weekly schedule, whereas the mechanical-broom sweeper was evaluated at two levels of operating frequency, weekly and monthly.

Street-dirt samples were collected weekly in the control and test basins by means of techniques described earlier in this report. The study was separated into two phases: (1) calibration and (2) treatment (street sweeping) on a weekly schedule. The calibration phase ran from June 2001 through September 2002 for the air-sweeper and low-frequency-broom basins and May 2002 through September 2002, and April to May 2005 for the highfrequency-broom basin. The treatment phase was conducted from April 2003 through September 2004 for the high- and low-frequency-broom basins, and April 2003 through May 2005 for the air-sweeper basin. Street-dirt sample collection was typically done during April through September to avoid snow and ice on street surfaces during winter and large amounts of organic detritus during fall. Street sweepers were dispatched to each basin in late March, after all remaining snow had melted, for a single pass prior to street-dirt sample collection; this served as a method to normalize each basin by limiting any bias from winter sand application and creating a common baseline for measurement of initial street-dirt yields. Table 5 details the street-dirt sample-collection schedule. 
Street-dirt yields are represented as pounds per curbmile. Results of previous studies showed that pounds per curb-mile is a more meaningful unit than simply pounds when evaluating sweeper effectiveness because it represents actual mass of constituent removed from a street surface (Pitt, 1979). A composite street-dirt yield, in pounds per curb-mile, for each basin was calculated by means of the following formula:

$$
P=\frac{\sum_{i=1}^{n}\left[\left(\frac{M \times 0.0022}{W \times N}\right) \times L_{f t}\right]}{\sum_{i=1}^{n} L_{m i}},
$$

where
$P$
is the mass of dirt on a street, in pounds per curb-mile;
$n \quad$ is the total number of streets in each basin;
$i \quad$ is an index to each street sampled in a study basin;
$M \quad$ is the total mass of sampled street-dirt, in grams;
$W \quad$ is the width of the vacuum nozzle, in feet;
$N \quad$ is the number of individual strips vacuumed per street;
$L_{f t} \quad$ is the length of each street, in feet;
$L_{m i} \quad$ is the length of each street, in miles; and
0.0022 is a unit conversion factor between grams and pounds.

\section{Calibration Phase}

Figure 6 characterizes basin street-dirt yields during the part of the study when street sweepers were not used. The calibration phase was established to develop relations between the control and test basins without the influence of normal street-sweeping operations. Street-dirt yields exhibited a non-normal distribution, as determined by an evaluation of normality with the Kolmogorov-Smirnov test at the 5-percent significance level. During this period, the air-sweeper basin had the highest median street-dirt yield, followed by the low-frequency broom, control, and highfrequency broom basins, respectively. However, results of the Kruskall-Wallis statistical test show no significant difference in median street-dirt yield between the four basins at the 5-percent significance level. Similarly, an examination of street dirt by particle size indicates no significant difference in distribution. The majority of particles in each basin were greater than 250 micrometers; 50 percent on average fell between the 250- and 1,000-micrometer particle-size fractions.

Previous studies indicate that dirt loading from street surfaces can vary widely and that the variation can be attributed to many factors, including differences in basin characteristics, study methods, and variation inherent in environmental factors (Steuer and others, 1997; Smith, 2002). Table 6 compares mean street-dirt yields in the control and test basins during the no-sweeping phase of this study to those measured in similar street-cleaning studies in other parts of the country. Given the similarities in

Table 5. Schedule for street-dirt sample collection.

\begin{tabular}{|c|c|c|c|c|c|}
\hline \multicolumn{7}{|c|}{ Year of study } \\
\hline $\mathbf{2 0 0 1}$ & $\mathbf{2 0 0 2}$ & $\mathbf{2 0 0 3}$ & $\mathbf{2 0 0 4}$ & $\mathbf{2 0 0 5}$ & $\mathbf{2 0 0 6}$ \\
\hline January & January & January & January & January & January \\
\hline February & February & February & February & February & February \\
\hline March & March & March & March & March & March \\
\hline April & April & April & April & April ${ }^{1}$ & April \\
\hline May & May & May & May & May & May \\
\hline June & June & June & June & June & June \\
\hline July & July & July & July & July & July \\
\hline August & August & August & August & August & August \\
\hline September & September & September & September & September & September \\
\hline October & October & October & October & October & October \\
\hline November & November & November & November & November & November \\
\hline December & December & December & December & December & December \\
\hline Decemb
\end{tabular}

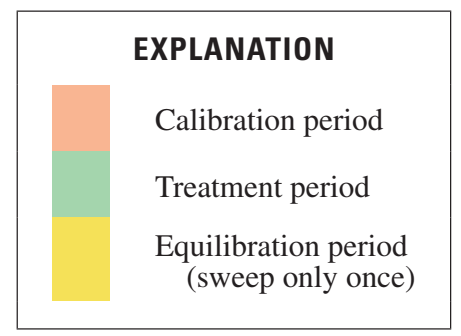

${ }^{1}$ Sweeping in air-sweeper basin and no sweeping in high-frequency broom basin. 


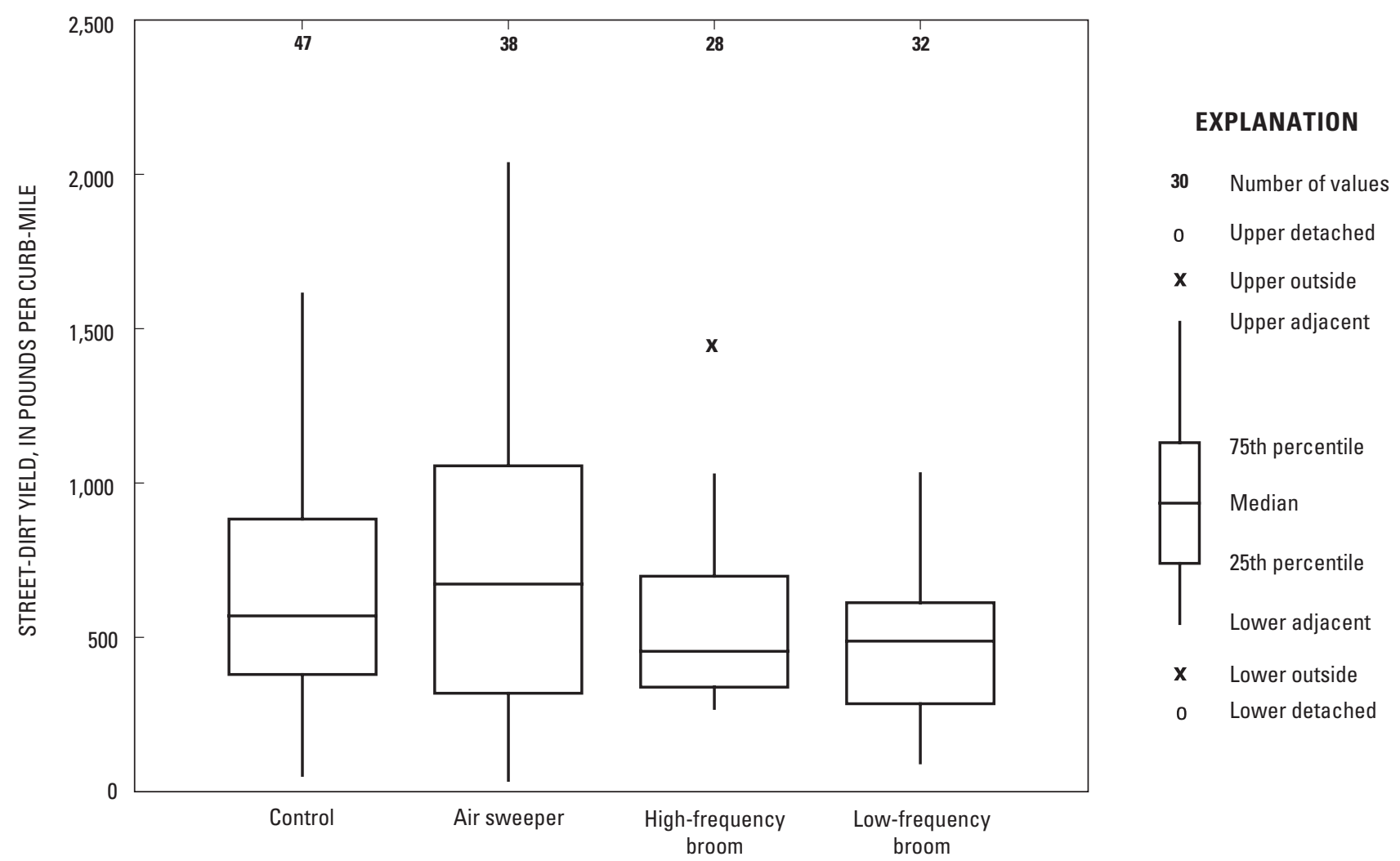

Figure 6. Average weekly street-dirt yields in the control and test basins during the calibration phase.

Table 6. Comparison of street-dirt yields, measured during the no-sweeping phase of this study in Madison, Wis., to those for other residential streets in the United States.

[--, no data; all values in pounds per curb-mile]

\begin{tabular}{|c|c|c|c|c|c|c|c|c|}
\hline \multirow[b]{2}{*}{ Statistic } & \multicolumn{4}{|c|}{ Study basin } & \multicolumn{4}{|c|}{ Previous studies } \\
\hline & Control & Air sweeper & $\begin{array}{l}\text { High-frequency } \\
\text { broom }\end{array}$ & $\begin{array}{c}\text { Low-frequency } \\
\text { broom }\end{array}$ & $\begin{array}{c}\text { Champaign, } \\
\text { III. }^{1}\end{array}$ & $\begin{array}{l}\text { Bellevue, } \\
\text { Wash. }\end{array}$ & $\begin{array}{l}\text { San Jose, } \\
\text { Calif. }^{3}\end{array}$ & $\begin{array}{c}\text { U.S. } \\
\text { nationwide }^{4}\end{array}$ \\
\hline Mean & 614 & 776 & 559 & 486 & 408 & 815 & 310 & 391 \\
\hline Median & 569 & 672 & 455 & 488 & -- & 705 & -- & -- \\
\hline
\end{tabular}

${ }^{1}$ Bender and Terstriep, 1984.

${ }^{2}$ Pitt, 1985.

${ }^{3}$ Pitt, 1979.

${ }^{4}$ Sartor and Boyd, 1972. 
average basin street-dirt yield, conclusions drawn from this study may be transferable to other residential communities across the Nation.

The high-frequency broom basin was added to the study in May 2002; therefore, this report does not include any street-dirt sample data before that date. The late start in this basin may have had an effect on the summary statistics for the basin because the majority of street-dirt yield is often measured in early spring. Had the basin been added in March or April, the median street-dirt yield represented in figure 6 would likely have been greater. The influence of spring street-dirt yield is illustrated in both the control and air-sweeper basins, where the months of April and May were included in 2002 but not 2001 (fig. 7). Figure 8 further shows the seasonal influence on basin street-dirt yield by highlighting proportions of average load contributions during spring, summer, and fall for the control and air-sweeper basins during the 2002 sample-collection year. Average basin street-dirt yield during spring was 20 to 50 percent greater than loads measured during summer or fall in the control and study basins.

Each of the four basins was treated identically in that other than the single sweeper pass in March of each year, no street sweeping was done during a calibration period of 2 years. Street-dirt data collected from the control basin was paired with data from each of the test basins to establish a quantifiable relation. The basis of this pairedbasin approach is that the relation between paired streetdirt yields for the control and tests basins is valid until a major change is made at one of the basins (Clausen and Spooner, 1993). At that time, a new relation will develop. The strength of this approach is that it does not require the assumption that the control and test basins are statistically the same; however, it does require that the two basins respond in a predictable manner together and that their relation remains the same over time except for the influence of street sweeping. Figure 9 represents the relations developed between the control and test basins during the calibration period. The relation is described by a simple linear regression. By use of analysis of variance (ANOVA), the significance of each linear regression was confirmed at the 5-percent significance level. There is a moderate to strong correlation between the control and test basin streetdirt yields, with correlation coefficients ranging from 0.73 to 0.80 for the high- and low-frequency broom basins, respectively.

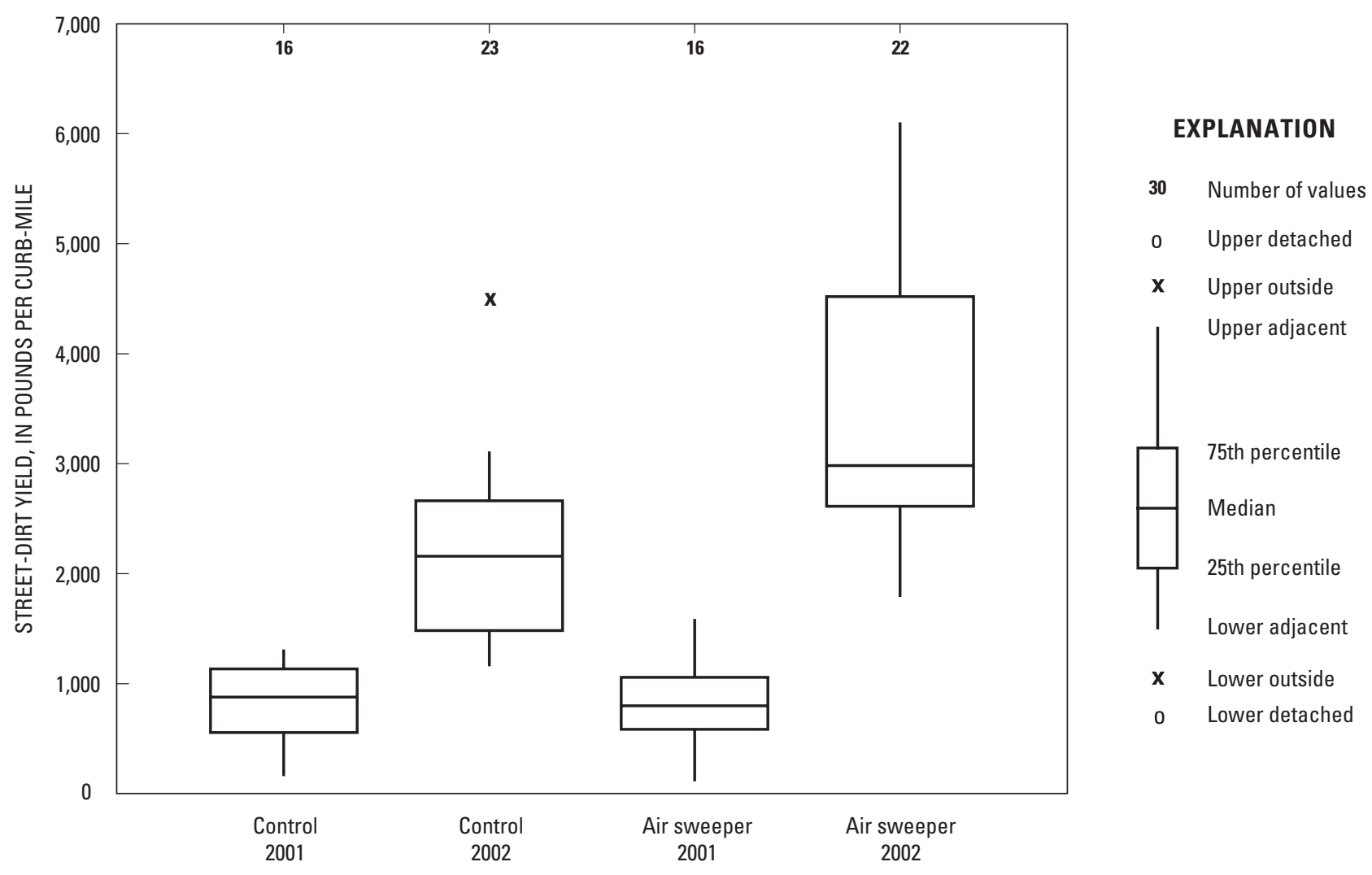

Figure 7. Influence of spring (April-May) street-dirt yield, in pounds per curb-mile, on total basin averages. 
Control

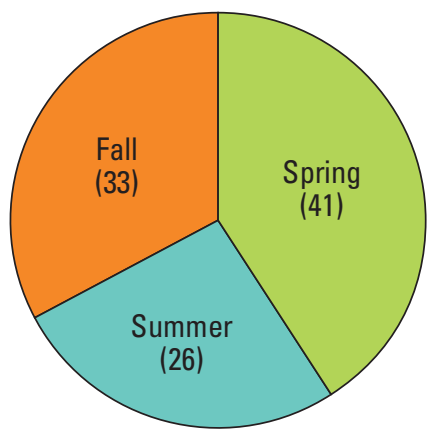

Air sweeper

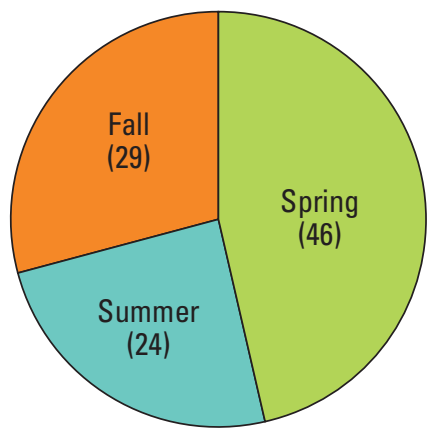

High-frequency broom

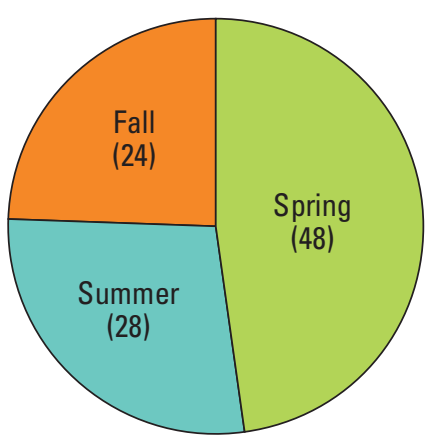

Figure 8. Average basin street-dirt yield categorized by season in the control and test basins during the 2002 calibration phase. Numbers in parentheses indicate percentage of street-dirt yield.

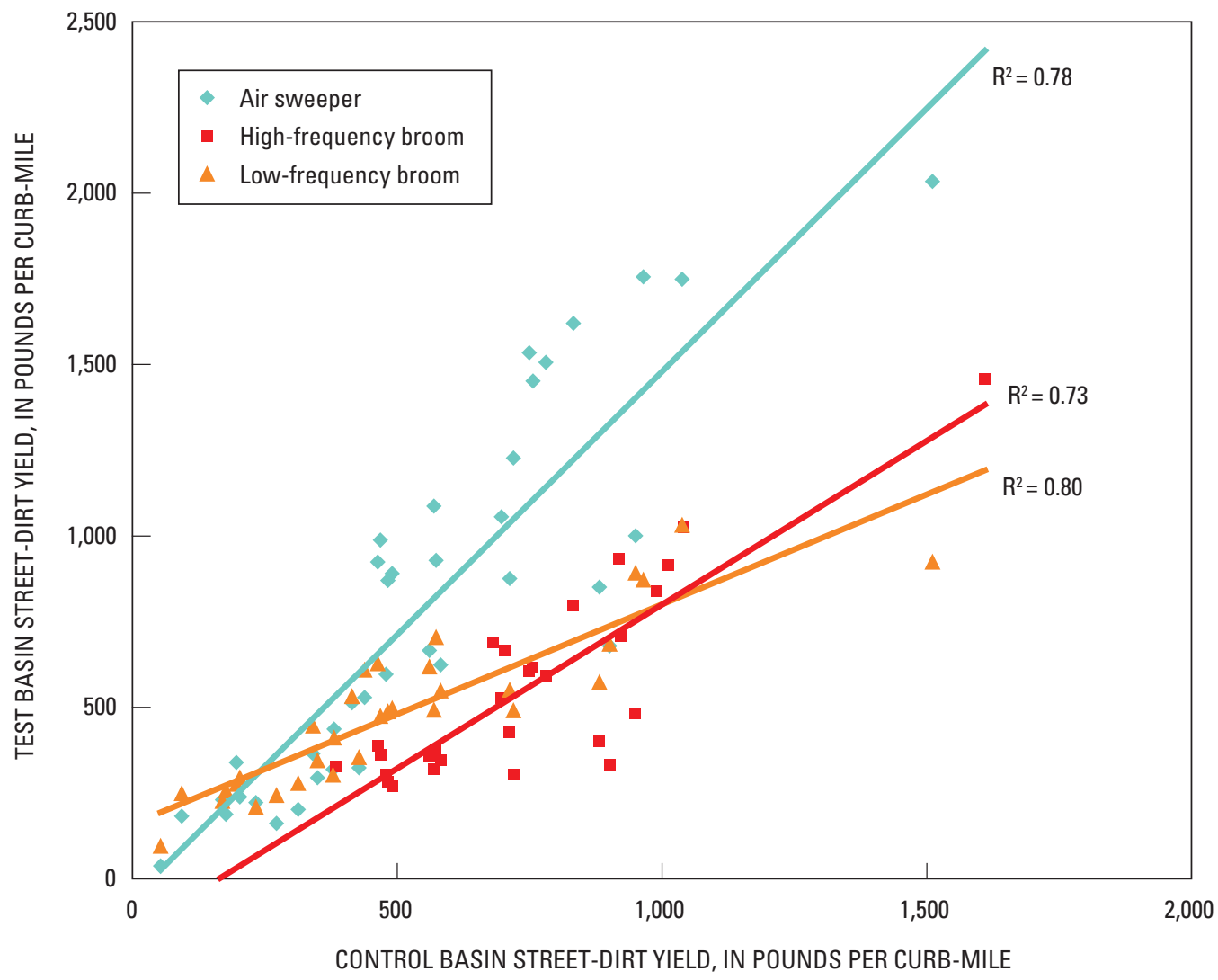

Figure 9. Paired-basin relation between the control and test basins during the calibration phase. 


\section{Treatment Phase}

In spring 2003, street sweepers were dispatched weekly to the air-sweeper and high-frequency broom basins. The low-frequency broom basin resumed the normal sweeping schedule for the city (approximately once per month). Street-dirt samples were collected before and after street sweepers cleaned each basin. An effort was made to minimize the amount of time between presweeping and postsweeping operations each week. Typically, postsweeper street-dirt samples were collected within 24 to 48 hours after presweeping samples were collected. All street-dirt sample collection was suspended during rain and as long as street surfaces remained wet. If a rain event occurred after the presweeping sample was collected, the postsweeping sample collection effort was postponed up to 1 day until street surfaces were sufficiently dry. If the duration of wet streets persisted beyond 1 day, the postsweeping sample collection effort was canceled. Of the 103 sampling trips scheduled during the course of the study, only 16 were canceled because of weather or mechanical problems.

\section{Weekly Street-Sweeper Performance}

During the treatment phase of the study, street-dirt samples were collected weekly to determine the streetdirt-removal capabilities of each street-sweeping program. Samples were acquired before and after street sweepers cleaned each test basin. The performance of each sweeper was determined by analyzing the difference between presweeping and postsweeping street-dirt yields.

Because of limitations in the street-dirt samplecollection process, the percentage reductions presented herein are somewhat underestimated. The presweeping and postsweeping street-dirt samples represent the load across the entire width of a street surface. A street sweeper's path typically extends only 8 feet from the curb (M. Kinter, Elgin Sweepers, written commun., 2006), leaving the middle of the street unswept. It was necessary to measure the street-dirt yield across the entire street width to adequately quantify the load available for washoff during runoff events; however, inclusion of unswept dirt from the middle of the street confounded the presweeping versus postsweeping load computations.

An attempt was made to estimate the reduction in street-dirt that lies only within the sweeper path, excluding the part of the street that is normally unswept. Several samples were collected in the air-sweeper basin, characterizing the distribution of street-dirt yields across the width of a street. A logarithmic regression was fit to cumulative street-dirt yields at a distance of 3 and 13 feet from the curb. By use of the regression, a presweeping and postsweeping street-dirt yield was interpolated at a distance of 8 feet from the curb. On average, reduction in street-dirt yields increased only slightly ( 5 percent) when focusing on the actual sweeper path compared to the entire street width. This analysis suggests that sampling the entire street width has minor influence on assessment of overall street-sweeper performance. Therefore, discussion on sweeper performance refers to the reduction of street-dirt yield across the entire street width, and thus the total available load, rather than only that which lies in the path of the sweeper. Results of street-dirt distribution are presented and discussed in greater detail later in the report.

Table 7 details street-dirt removal statistics for each street sweeper evaluated during the study. A negative percentage indicates that more material was added than removed. The regenerative-air and vacuum-assist sweepers performed similarly over the range of measured values.

Table 7. Summary statistics of average basin street-dirt change for the regenerative-air, vacuum-assist, and high-frequency mechanical broom sweepers during the treatment phase. A negative value indicates an increase in street-dirt yield after sweeping.

[all values given in percent]

\begin{tabular}{lccc}
\hline \multirow{2}{*}{ Statistic } & \multicolumn{3}{c}{ Yield reduction, by sweeper type } \\
\cline { 2 - 4 } & Regenerative air & Vacuum assist & High-frequency broom \\
\hline Maximum & 51 & 52 & 46 \\
Minimum & -3 & -2 & -41 \\
Mean & 25 & 30 & 5 \\
Median & 29 & 30 & 5 \\
Number of samples & 21 & 19 & 37 \\
\hline
\end{tabular}


The vacuum-assist sweeper had slightly better removal capabilities with respect to the mean and median values. On average, the mechanical broom had minor removal capabilities and often would add to the overall streetdirt yield after cleaning. However, results of a Wilcoxon signed-ranks test (Helsel and Hirsch, 1992), used to find differences between non-normally distributed paired data sets, showed a slight but significant reduction from presweeping to postsweeping street-dirt yields for the highfrequency broom basin at the 95-percent confidence level. Similar tests for the regenerative-air and vacuum-assist sweepers also showed a significant reduction in street-dirt yield at the 95-percent confidence level.

Many studies report a range of measured and simulated sediment removal capabilities ranging from 35 to over 90 percent for regenerative-air or vacuum-assist sweeper technologies (Sutherland and Jelen, 1997; The Terrene Institute, 1998; Bannerman, 1999; Shoemaker and others, 2000, as cited in Zarriello and others, 2002). Similarly, Breault and others (2005) measured overall average street-sweeper efficiency ranging from 60 to 92 percent for a vacuum-assist sweeper. The methods used to determine pickup efficiency in these cases typically involved one or more passes of a street sweeper over a premeasured, mechanically applied street-dirt mix on a test street surface. Although this approach may describe the performance of a street sweeper under a very specific set of controlled conditions, it may not fully test the range of loading conditions represented by a variety of street surfaces with varying initial street-dirt yields over time. In contrast, this study evaluated sweepers under the conditions in which they are typically used.

Of the 37 paired street-dirt samples collected in the high-frequency broom basin, 14 pairs showed an increase in street-dirt yield after the sweeper cleaned the basin; in contrast, 2 postsweeping loads were greater than presweeping loads for the regenerative-air and vacuum-assist sweepers combined. One explanation for an increase in street-dirt yield after sweeping is the abrasive action of the wire bristles attached to the gutter brooms of each sweeper. By scouring the pavement, the wire-bristle brooms may loosen particles embedded in cracks found in the pavement or simply tear up the pavement itself. Although all three sweeper technologies make use of a wire-bristled gutter broom, the regenerative-air and vacuum-assist sweepers are better suited to remove a broader range of particles available for washoff by adding a powerful blast of air and (or) vacuum suction. The mechanical-broom sweeper simply passes any debris captured by the gutter broom into the path of a second, center-transfer broom.

The differences in street-dirt pickup efficiency between each sweeper can be further evaluated by analysis of particle size. Previous studies found mechanical-broom sweepers to be poorly suited for picking up particles of less than 10 to 250 micrometers (U.S. Environmental Protection Agency, 1983; Bender and Terstriep, 1984; Pitt, 1985; Wheaton and others, 1999; Shoemaker and others, 2000). Figure 10 illustrates the average weekly percent reduction of street dirt for particle sizes ranging from greater than 2,000 to less than 63 micrometers. As

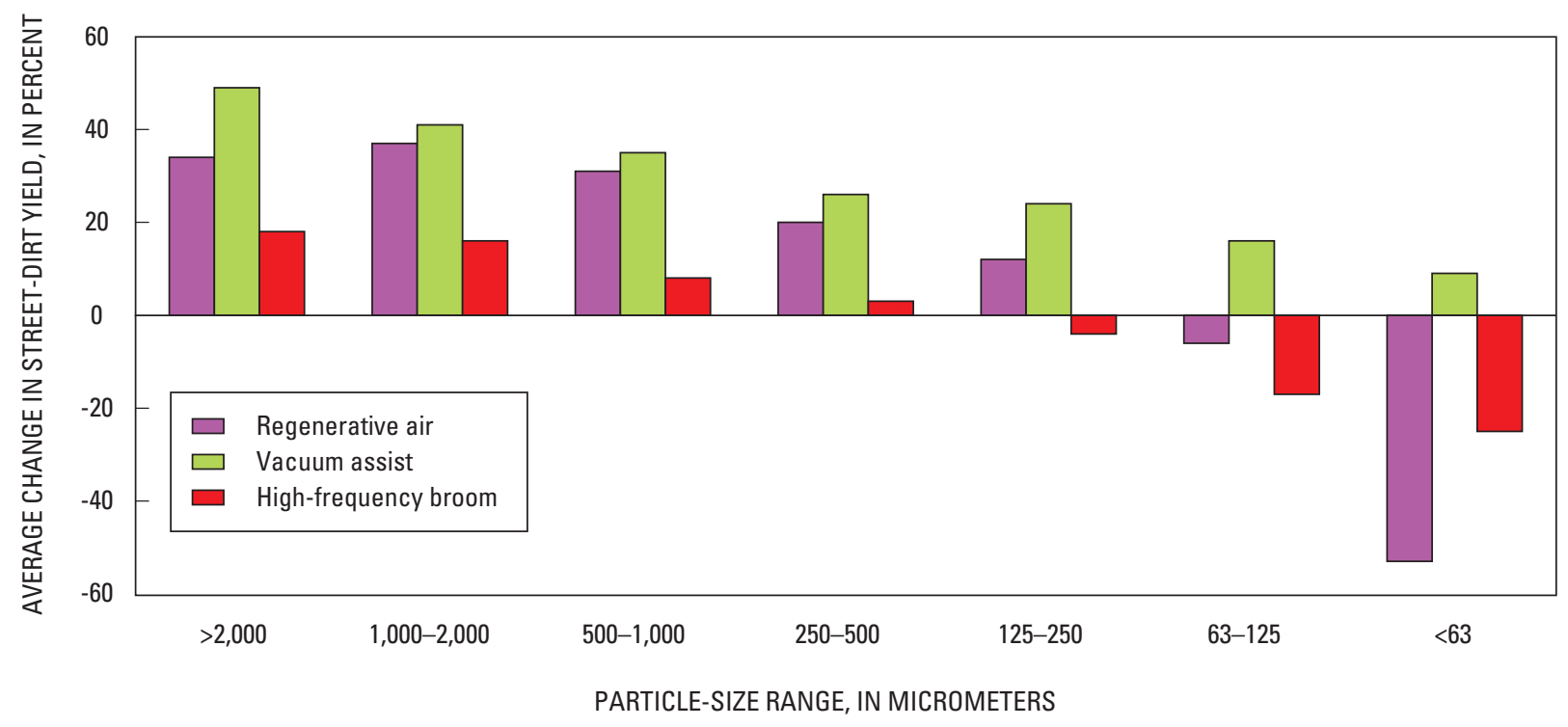

Figure 10. Average changes in weekly street-dirt yield as a function of particle size for three street-sweeping treatments in Madison, Wis. A negative value indicates an increase in street-dirt yield after sweeping. 
in table 7, a negative percentage indicates more material was added than removed. Reductions of street-dirt yield decreased with decreasing particle size for all sweepers. The high-frequency mechanical broom and regenerativeair sweepers were unable to adequately pick up particles less than 250 and 125 micrometers, respectively. Only the vacuum-assist sweeper was capable of reducing street-dirt yield across the entire range of particle sizes measured. Even at the smallest particle-size fraction, less than 63 micrometers, the vacuum-assist sweeper was able to reduce a percentage of the street-dirt yield by incorporating a powerful vacuum that extends into the curb, overlapping part of the gutter-broom. The vacuum appears to capture most of what the gutter broom cannot.

\section{Changes in Street-Dirt Distribution on a Street Surface}

Pitt and Amy (1973) found that street dirt is unevenly distributed across the street surface and that 90 percent of the street-dirt total mass is within the first foot of the curb. A test was done during this study to identify the distribution of street dirt across a street width. Sampled streets in the air sweeper basin were split into "curb" and "center" lanes. The curb lanes stretched out 3 feet from the curb on each side of the street (fig. 11). The remaining 26 feet was considered the center lane (fig. 11). Table 8 shows the percentage contribution of street dirt for each lane from April through early June 2005. When normalized by area, the curb lanes contained less street dirt than the center lane during the early spring months. This result is likely due to remnants of winter sand, which is typically applied in residential areas for traction enhancement (A. Schumacher,
Table 8. Distribution of street-dirt yield before and after street sweeping on a single street in the air-sweeper basin, April to June 2005.

[all values given in percent of total street-dirt yield]

\begin{tabular}{lcccccc}
\hline \multirow{2}{*}{ Date } & \multicolumn{2}{c}{ Curb } & & \multicolumn{2}{c}{ Center } \\
\cline { 2 - 3 } \cline { 6 - 7 } \cline { 5 - 6 } \cline { 5 - 6 } April 21, 2005 & Before & After & & Before & After \\
April 28, 2005 & 44 & 27 & & 70 & 73 \\
May 5, 2005 & 46 & 29 & & 54 & 71 \\
May 18, 2005 & 64 & 23 & & 36 & 77 \\
May 25, 2005 & 71 & 30 & & 29 & 70 \\
June 2, 2005 & 74 & 27 & & 26 & 73 \\
\hline
\end{tabular}

City of Madison, written commun., 2006). However, each successive week recorded a transgression of street-dirt from the center to the curb lanes. By early summer, the curb lanes contained approximately 75 percent of the street dirt. This distribution was confirmed by an earlier test in August 2003 showing that 77 percent of street-dirt was contained in the curb lane. Furthermore, it appears the vacuum-assist sweeper operating in the basin during this test was able to reduce street dirt yield in the curb to a consistent level. This is evident from postsweeping streetdirt yield distribution percentages remaining relatively the same (approximately 25 percent) in the spring and summer, regardless of presweeping load (table 8). Despite more street dirt moving from the center lane to curb lanes, the vacuum-assist sweeper was able to remove the increased load and maintain a stable distribution across the street width.

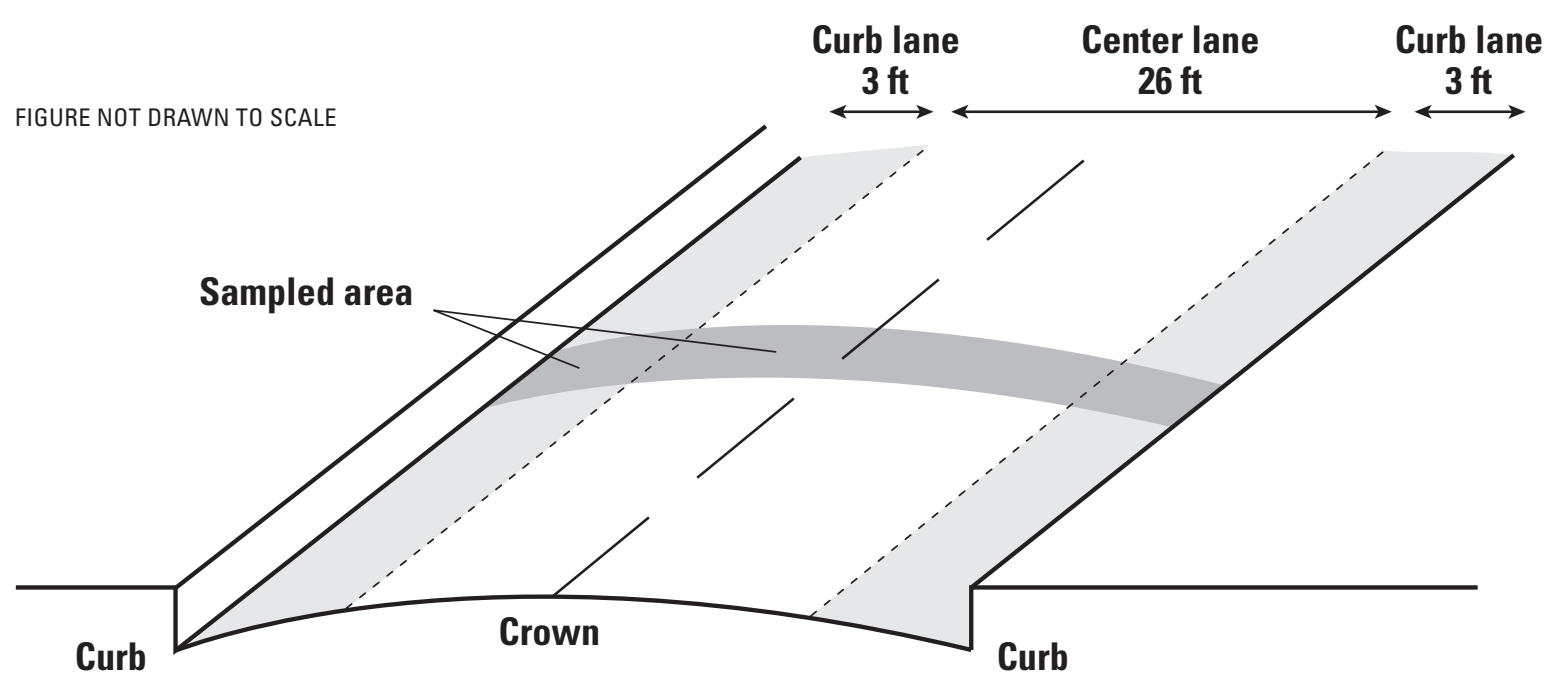

Figure 11. Location of sub-sampling strips to determine the distribution of street-dirt yield across a street. 
The Nationwide Urban Runoff Program (NURP) recognized that street-dirt removal performance is higher with increasing street-dirt yield and that a certain residual load remains on each street at which no additional sweeping has any beneficial impact (Bannerman and others, 1983). Figure 12 illustrates how sweeper-removal rates vary proportionally to the available initial street-dirt yield in each of the test basins. For each sweeper evaluated, the amount of street dirt removed increased with increasing initial street-dirt yield. The mechanical broom sweeper appears to be relatively ineffective until the initial street-dirt yield approaches 1,000 pounds per curb-mile, whereas both the regenerative-air and vacuum-assist sweepers are effective at much lower initial street-dirt yields (fig. 12). Typically, street-dirt yields of this magnitude are measured during early spring months and are a reflection of the abovementioned accumulated sand applied during the winter for better traction. Therefore, street-sweeping programs utilizing mechanical-broom sweepers could improve the overall reduction of street dirt by cleaning the entire street width rather than just the curb lanes during periods of heavy loading commonly associated with winter sand application in cold climates.

\section{Changes in Basin Street Dirt as a Result of Street Sweeping}

Figure 13 details average weekly street-dirt yields in each basin during the treatment phase. The data used to build figure 13 represent the weekly basin street-dirt yield before street sweepers entered each basin. The street-dirt yields presented in figure 13 for the air-sweeper basin represent a combined effect of the regenerative-air and vacuum-assist sweepers. The control basin (not swept) had the highest median street-dirt yield with decreasing yields in the low-frequency broom, high-frequency broom, and air-sweeper basins, respectively. Table 9 details the average basin percent distribution of particle sizes measured during the calibration and treatment phases. Similar to the calibration phase, the majority of particles in each basin during the treatment phase were greater than 250 micrometers. Both the regenerative-air and vacuum-assist sweepers produced slight reductions of particles greater than 250 and 500 micrometers, respectively. The broom sweeper, regardless of operating frequency, was only capable of reducing particles greater than 1,000 micrometers. All sweepers evaluated during this study produced slight increases in the percentage of particles less than 125 micrometers.

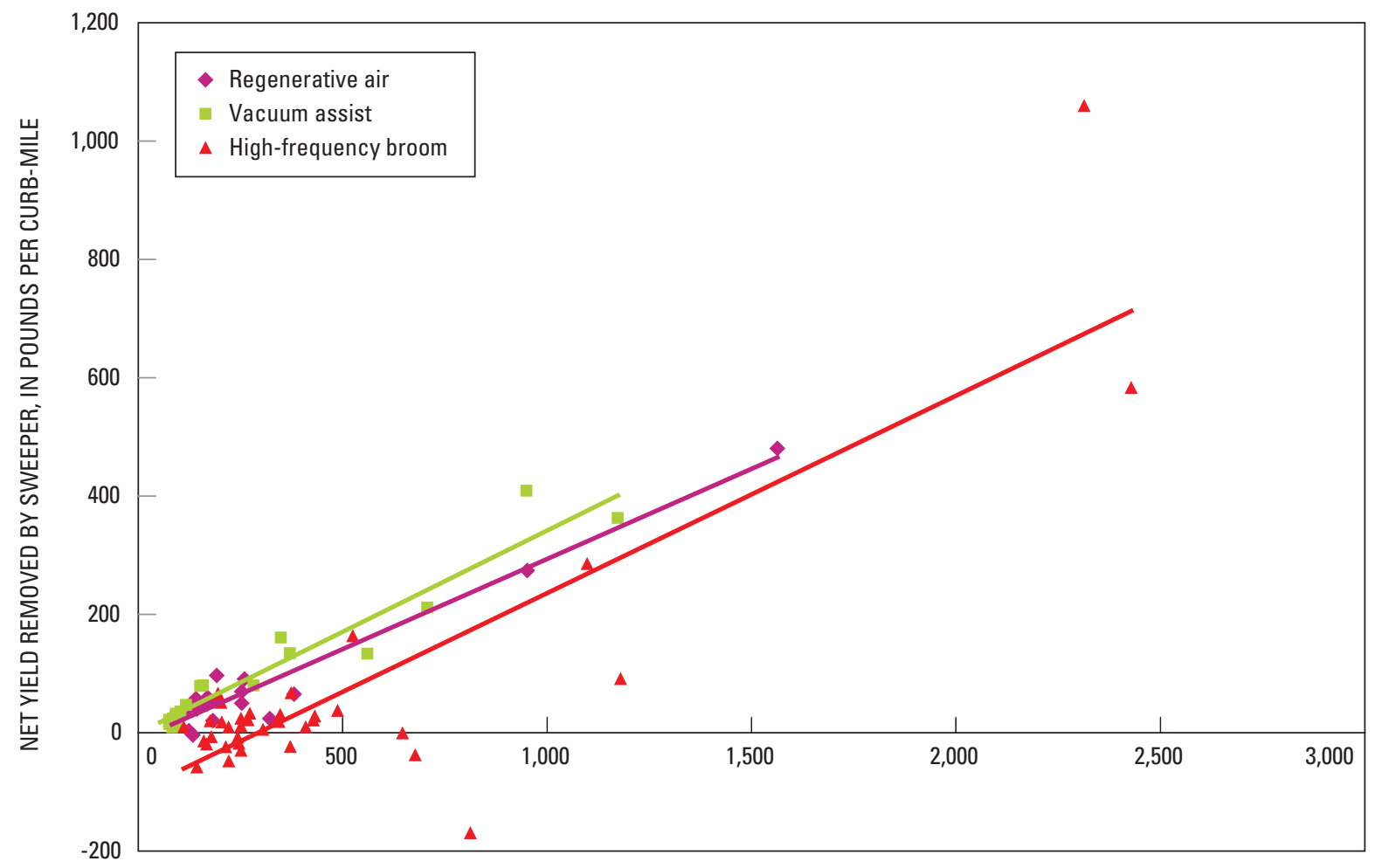

INITIAL YIELD, IN POUNDS PER CURB-MILE

Figure 12. Street sweeper removal capabilities as a function of initial street-dirt yield, in pounds per curb-mile. A negative value for net yield removed indicates an increase in street-dirt yield after sweeping. 


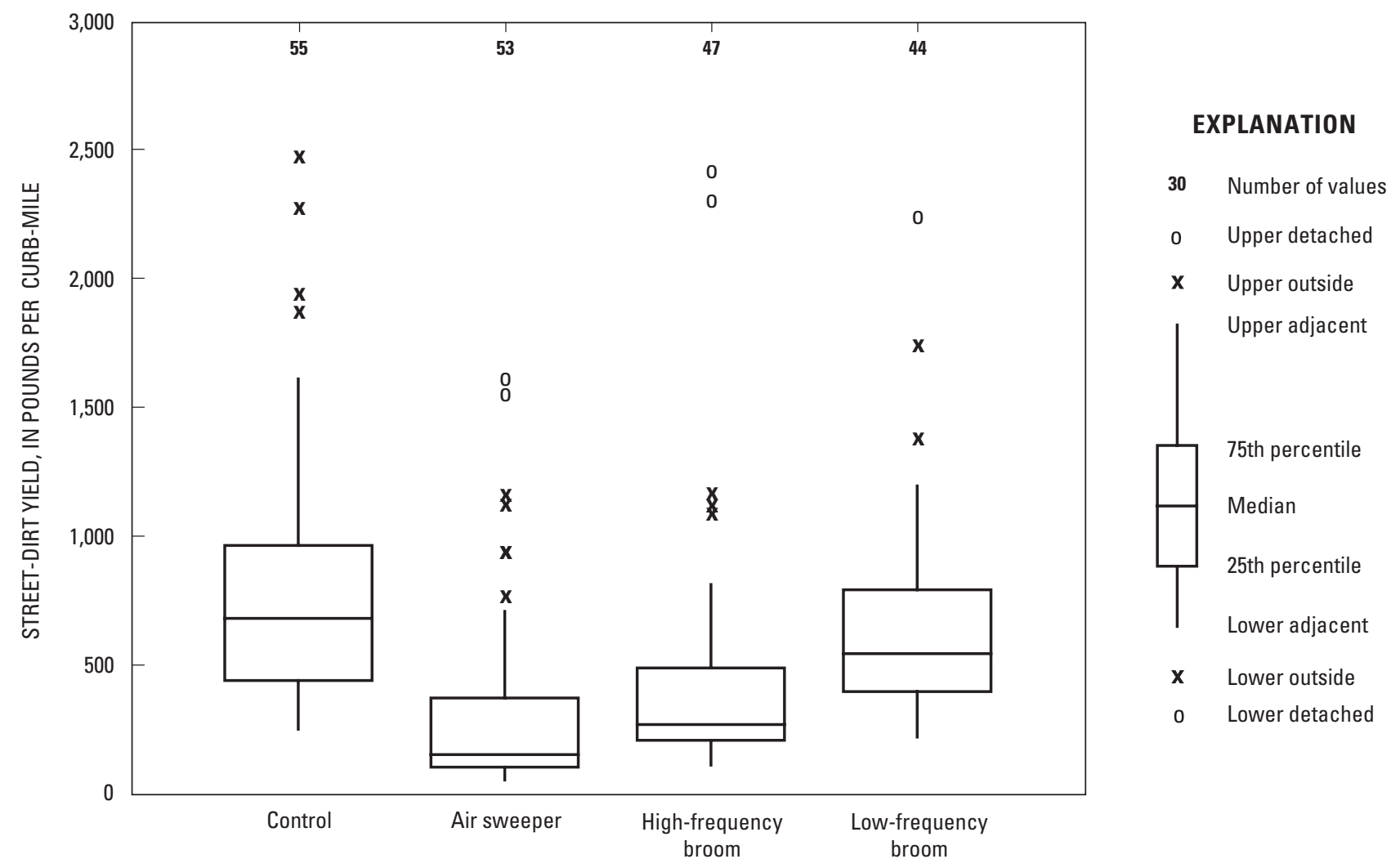

Figure 13. Average weekly street-dirt yield, in pounds per curb-mile, during the treatment phase.

Table 9. Distribution of particles measured from street surfaces in the control and test basins during the calibration and treatment phases.

[>, greater than; <, less than; all values given in percent of total mass; columns may not total to 100 percent because of independent rounding]

\begin{tabular}{|c|c|c|c|c|c|c|c|c|c|}
\hline \multirow{3}{*}{$\begin{array}{l}\text { Particle size } \\
\text { (micrometers) }\end{array}$} & \multicolumn{9}{|c|}{ Percent of total mass, by basin and phase of study } \\
\hline & \multicolumn{2}{|c|}{ Regenerative air } & \multicolumn{2}{|c|}{ Vacuum assist } & \multicolumn{2}{|c|}{$\begin{array}{c}\text { High-frequency } \\
\text { broom }\end{array}$} & \multicolumn{2}{|c|}{$\begin{array}{c}\text { Low-frequency } \\
\text { broom }\end{array}$} & \multirow{2}{*}{ Contro } \\
\hline & Calibration & Treatment & Calibration & Treatment & Calibration & Treatment & Calibration & Treatment & \\
\hline Detritus & 6 & 8 & 6 & 5 & 3 & 3 & 8 & 3 & 2 \\
\hline$>2,000$ & 9 & 6 & 9 & 8 & 8 & 7 & 10 & 8 & 10 \\
\hline $1,000-2,000$ & 12 & 9 & 12 & 9 & 12 & 11 & 12 & 11 & 12 \\
\hline $500-1,000$ & 20 & 16 & 20 & 16 & 21 & 22 & 18 & 19 & 19 \\
\hline $250-500$ & 31 & 30 & 31 & 33 & 32 & 33 & 27 & 31 & 30 \\
\hline $125-250$ & 15 & 18 & 15 & 17 & 15 & 16 & 15 & 17 & 16 \\
\hline $63-125$ & 4 & 7 & 4 & 7 & 5 & 5 & 6 & 6 & 6 \\
\hline$<63$ & 3 & 5 & 3 & 5 & 4 & 3 & 3 & 4 & 5 \\
\hline
\end{tabular}


According to the paired-basin approach, any change in the relation established between the control and test basins during the calibration phase of the study can be attributed directly to street-sweeping activity. The magnitude of change may reflect upon the technology of the sweeper used, the frequency of sweeping, or both. Changes in the relation between paired data during the treatment phase of the study are highlighted in figures 14a-c. As with the calibration regression, an ANOVA test was performed on each treatment regression to confirm its significance at the 5-percent level.

At the end of the treatment period, the significance of the effect of street sweeping was determined using analysis of covariance (ANCOVA) (Clausen and Spooner, 1993). Results of the ANCOVA test indicate a significant change (95-percent confidence level) between the calibration and treatment relations in the air-sweeper basin for both the regenerative-air and vacuum-assist sweepers. The high-frequency broom basin also had a significant change (95-percent confidence level) in the intercept of the treatment regression. However, a change in slope between the calibration and treatment phases for the high-frequency broom basin was determined to be insignificant. This indicates an overall parallel shift in the regression equation. In this case, the treatment regression shifted below that of the calibration phase, demonstrating some level of benefit at reducing street-dirt yields. The low-frequency broom basin did not have a significant change for either the slope or intercept of the treatment regression, suggesting little to no change in street-dirt yields when compared to the calibration phase. If the results of the ANCOVA test for slope and (or) intercept reveal a significant difference between the calibration and treatment regressions, the regression equation representing the calibration period for the control basin can be used to quantify the degree of street-dirt reduction as a result of street sweeping by predicting what average weekly street-dirt yields should have been during the treatment phase in the absence of street sweeping. The overall reduction due to street sweeping can then be expressed as a percentage change on the basis of the average predicted and observed values during the treatment phase (Clausen and Spooner, 1993). The regenerative-air and vacuum-assist sweepers, used on a weekly basis, resulted in the largest reduction in street-dirt yields at 76 and 63 percent, respectively. These reductions are represented graphically in figure 14a. The broom sweeper at the high-frequency schedule had less influence, removing only 20 percent of the basin street-dirt yield (figure 14b). Because the results of the ANCOVA test indicated no significant difference between the calibration and treatment phases in the low-frequency broom basin, any reduction in street-dirt yield as a result of street sweeping was negligible (figure 14c). Table 10 lists street-dirt-yield summary statistics for each basin during the calibration and treatment phases.

Street sweepers can alter the amount of street-dirt washed off a street during a runoff event by increasing the percentage of fine particles (less than 63 micrometers) (Bannerman and others, 1983; Pitt and others, 2004). The increase in fines is typically a combination of the mechanical action of the gutter broom on the sediment adhered tightly to the pavement and the preferential removal of the larger particles on the street. Evidence exists that some of the fine particles are not available for washoff in the absence of street sweeping but are available only after the gutter broom dislodges them from the pits and cracks in the street (Pitt and others, 2004). The percentage of fines on streets in the air-sweeper and high-frequency broom basins sometimes increased after a street sweeper passed (fig. 10). By removing the majority of larger particles (greater than 63 micrometers) on a street surface, street sweepers also reduce the armoring of fine particles (Burton and Pitt, 2002).

Increasing the amount of fines on a street can change its washoff characteristics because rain can be more effective at removing smaller particles from streets than street sweepers (Pitt and others, 2004). Consistent with previous studies, the three types of street sweepers tested in this study were able to remove a greater percentage of larger particles than smaller particles (fig. 10). In contrast, work done by Pitt (1985) shows that the amount of particles washed off a street surface increases as particle size decreases. Stormwater-quality samples collected at the airsweeper basin outlet also show a higher percentage of fines in the runoff than in the street dirt. During the treatment periods, the amount of fines in the runoff averaged about 40 percent (table 15), whereas only about 5 percent of the street dirt was in the less than 63-micrometer size fraction (table 9). If the amount of fines washed off a street surface is increased by street sweeping, the reduction in the streetdirt yield could be a function of both the street sweepers and the increased effect of rainfall.

\section{Effect of Rainfall on Street Dirt}

In addition to street sweeping, removal of streetdirt can occur naturally by wind, rain, or human activity, such as vehicular traffic. Previous studies have shown significant removal of street dirt (up to 90 percent) for rains exceeding 10 millimeters ( $0.39 \mathrm{inch}$ ) (Pitt and Amy, 


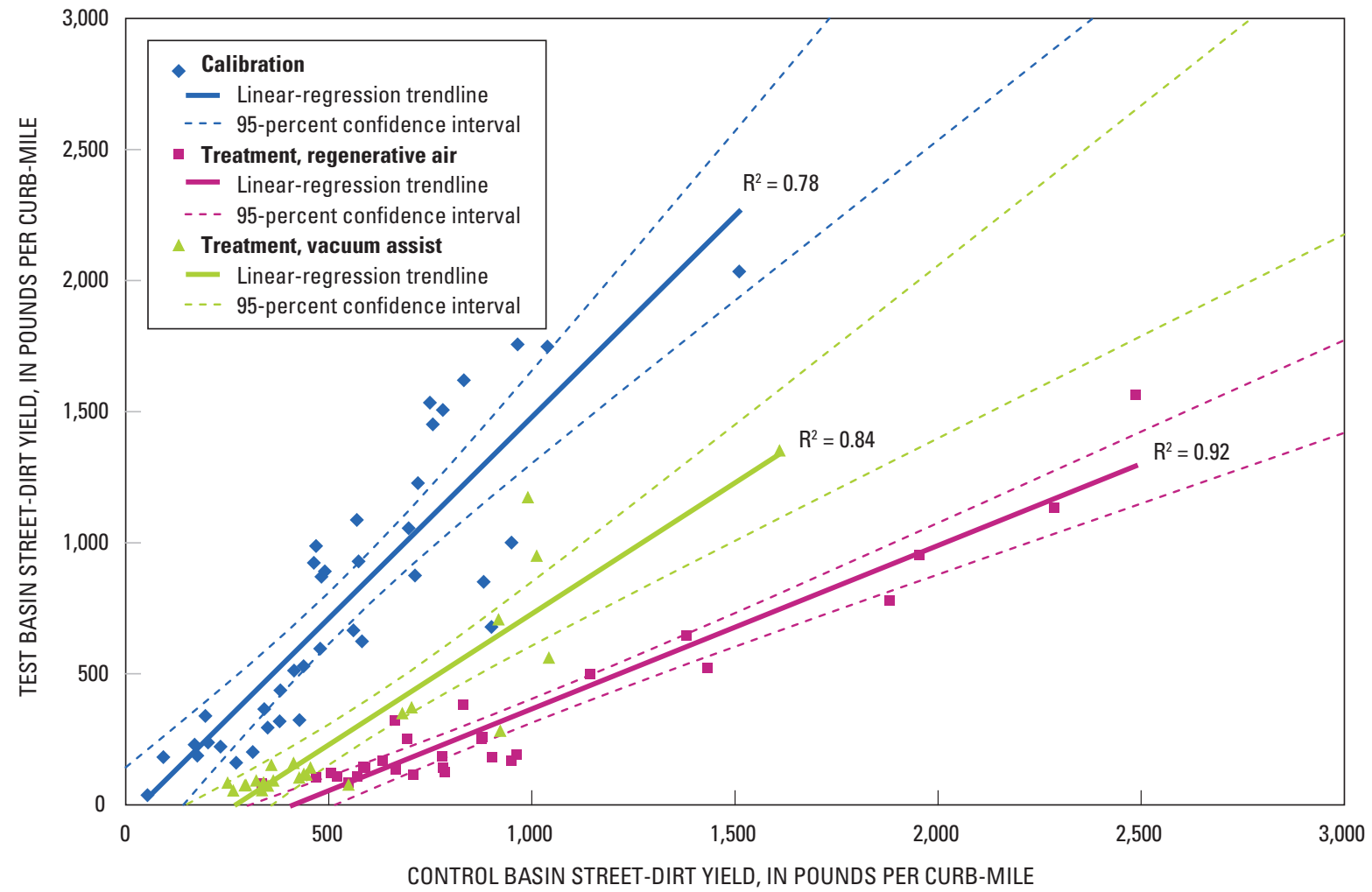

Figure 14a. Response of average weekly street-dirt yield, in pounds per curb-mile, to street sweeping in the air-sweeper basin.

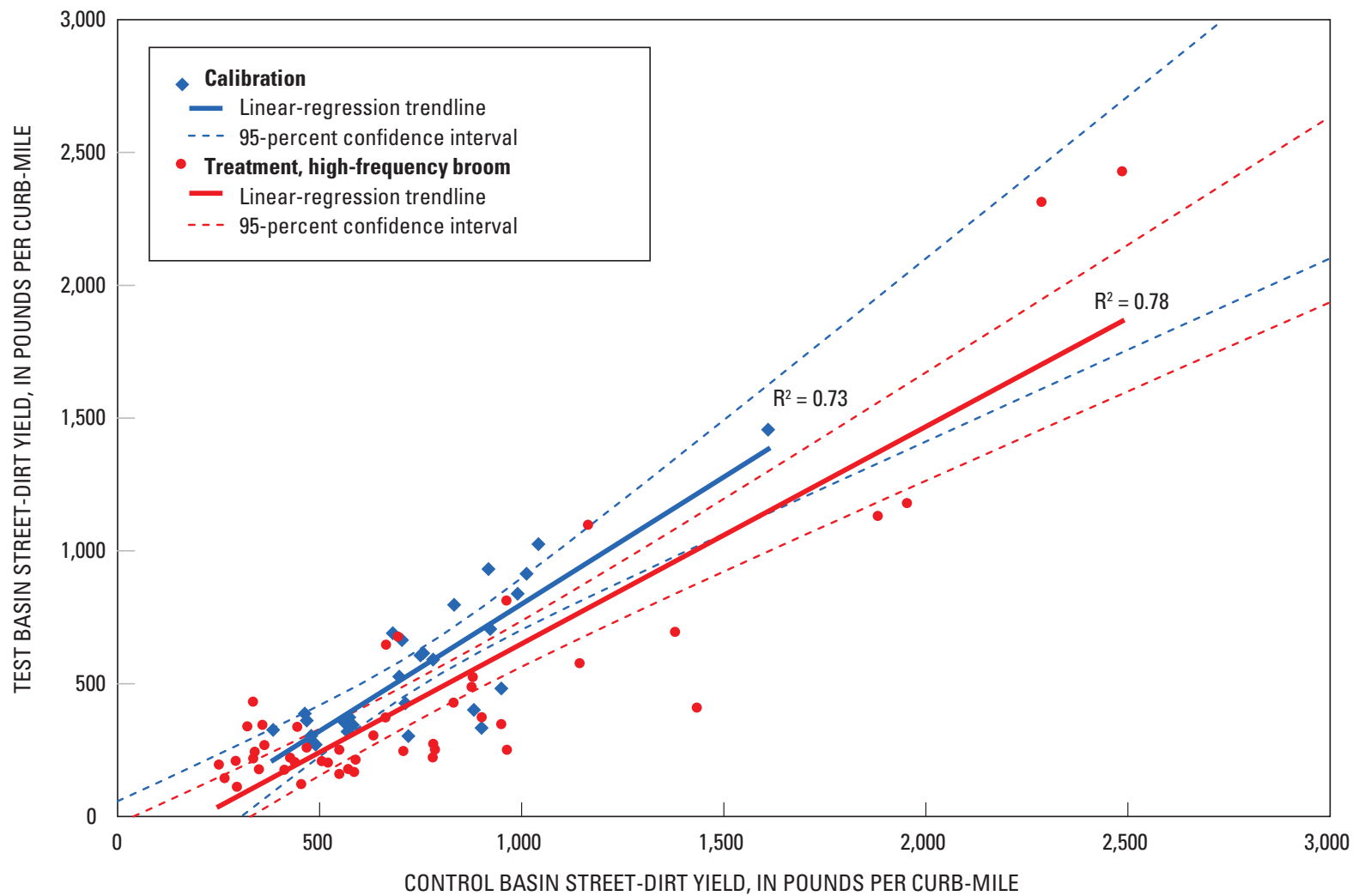

Figure 14b. Response of average weekly street-dirt yield, in pounds per curb-mile, to street sweeping in the high-frequency broom basin. 


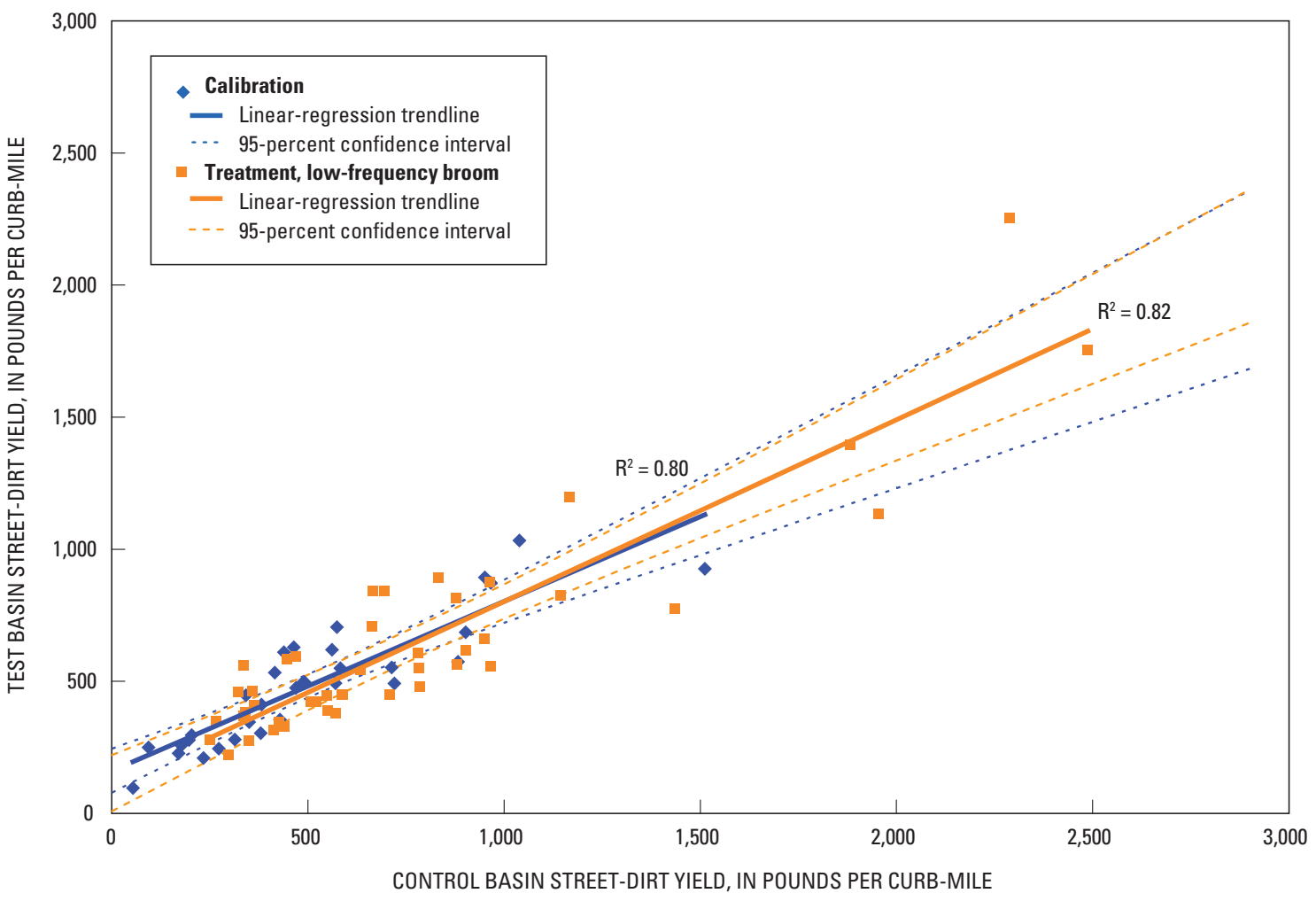

Figure 14c. Response of average weekly street-dirt yield, in pounds per curb-mile, to street sweeping in the low-frequency broom basin.

Table 10. Summary statistics of average basin street-dirt yields for the control and test basins during calibration and treatment phases.

[all values in pounds per curb-mile]

\begin{tabular}{|c|c|c|c|c|c|}
\hline \multirow{3}{*}{ Statistic } & \multicolumn{5}{|c|}{ Basin } \\
\hline & \multirow{2}{*}{ Control } & \multicolumn{2}{|c|}{ Air sweeper (type of sweeper) } & \multirow{2}{*}{$\begin{array}{l}\text { High-frequency } \\
\text { broom }\end{array}$} & \multirow{2}{*}{$\begin{array}{c}\text { Low-frequency } \\
\text { broom }\end{array}$} \\
\hline & & Regenerative air & Vacuum assist & & \\
\hline \multicolumn{6}{|c|}{ Calibration phase } \\
\hline Maximum & 1,610 & 2,034 & 2,034 & 1,457 & 1,030 \\
\hline Minimum & 53 & 37 & 37 & 270 & 94 \\
\hline Mean & 614 & 776 & 776 & 558 & 486 \\
\hline Median & 569 & 672 & 672 & 455 & 488 \\
\hline Standard deviation & 338 & 526 & 526 & 279 & 226 \\
\hline Coefficient of variation & 0.56 & 0.69 & 0.69 & 0.51 & 0.47 \\
\hline Number of samples & 47 & 38 & 38 & 28 & 32 \\
\hline \multicolumn{6}{|c|}{ Treatment phase } \\
\hline Maximum & 2,486 & 1,563 & 1,352 & 2,428 & 2,250 \\
\hline Minimum & 251 & 82 & 54 & 111 & 220 \\
\hline Mean & 794 & 340 & 304 & 456 & 639 \\
\hline Median & 681 & 182 & 116 & 269 & 544 \\
\hline Standard deviation & 492 & 352 & 366 & 477 & 392 \\
\hline Coefficient of variation & 0.63 & 1.03 & 1.20 & 1.06 & 0.62 \\
\hline Number of samples & 55 & 31 & 24 & 47 & 44 \\
\hline
\end{tabular}


1979). Frequent rains can also minimize the accumulation of street dirt over time. A study in Bellevue, Wash., concluded that frequent rains were more effective at keeping streets clean than street sweeping was (Pitt, 1985). Frequent rains add complexity when evaluating the performance of street sweepers simply because it is difficult to determine the amount of street dirt removed by rain or by the street sweeper. Furthermore, large storms can wash dirt onto street surfaces from surrounding areas (U.S. Environmental Protection Agency, 1982).

One solution is to collect street-dirt samples at frequent intervals, such as daily. However, financial limitations preclude such an undertaking in most studies. An example of how rainfall can affect total basin street-dirt yield is illustrated in figure 15. Of particular note is how total street-dirt yield in the control basin remained relatively constant in 2002 and 2003, then fell sharply in 2004.
The majority of street-dirt yield measured during April and May was likely residual sand from application during prior winter months. The combined rainfall totals for April and May were 6.07, 7.18, and 13.61 inches in 2002, 2003, and 2004, respectively. Because of the large amount of available street dirt during this time, rainfall may have the greatest impact on available street-dirt yield. This is especially true if early spring rains precede sweeper deployment. If the monthly rainfall for April and May in 2004 had been similar to the corresponding values for previous years, one might expect a similar pattern of basin streetdirt yield. The control and test basins were located close to each other to reduce variability due to isolated rainstorms. However, the cleansing action of rain could have a more pronounced affect on sediment washoff in the study basins by altering the physical characteristics of street dirt caused by street sweeping.

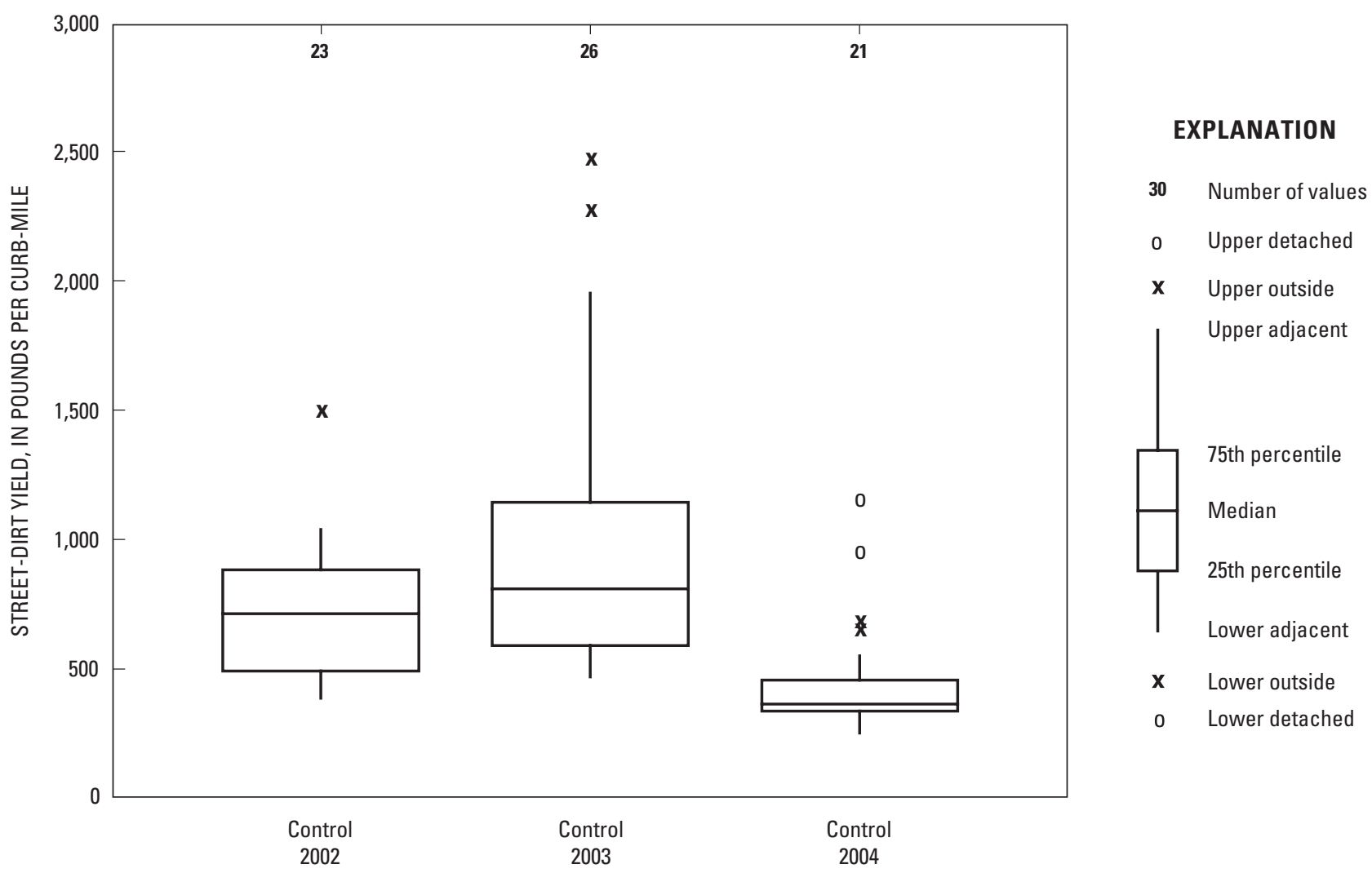

Figure 15. Comparison of street-dirt yields in the control basin, 2002-2004 (reduced yield in 2004 is the result of excessive rainfall during the period April to May 2004). 


\section{Effects of Street Sweeping on Stormwater-Runoff Quality}

In addition to street-dirt removal, changes in the quality of stormwater runoff were measured to determine whether street sweeping could reduce sediment and sediment-associated constituent concentrations and loads at the basin outfall. The effects of street sweeping on stormwater-runoff quality were evaluated by use of statistical tests to compare flow-weighted event mean concentrations and loads computed for individual storms at the control and test basins. Loads were computed by multiplying the event mean concentrations by stormwater runoff volumes. Results of the tests indicate little probability that street sweeping, regardless of sweeper type, had any measurable affect on the quality of runoff.

\section{Previous Studies}

Literature reviews from previous studies (Zarriello and others, 2002; Breault and others, 2005) highlight a wide range of street-sweeper efficiencies for the reduction of end-of-pipe constituent concentrations and loads in urban runoff. The majority of street-sweeping studies in the late 1970s and early 1980s examined primarily mechanical-broom-type sweepers. More recent studies have included the evaluation of newer sweeper technologies, such as regenerative-air and vacuum-assist type sweepers. However, most studies evaluating these sweeper technologies are limited in the number of constituents measured during the course of the study. Removal of sediment is typically reported, but other sediment-associated constituent concentrations such as phosphorus and metals are rarely discussed (Zarriello and others, 2002).

Many of the studies done as part of the Nationwide Urban Runoff Program (NURP) examined the effectiveness of mechanical sweepers. Those studies concluded that street sweeping was not a viable stormwater-qualitymanagement practice (Smith and Lord, 1990; Sartor and Gaboury, 1984; Atahyde and others, 1983; Sartor and Boyd, 1975, as cited in Zarriello and others, 2002). Bender and Terstriep (1984) and Prych and Ebbert (1986) also indicated the ineffectiveness of mechanical-broom sweepers by noting no significant differences in event mean concentrations before and after sweeping. Other mechanicalbroom-sweeper studies reported as much as a 30-percent reduction in end-of-pipe sediment loads, but only under favorable conditions (Sartor and Gaboury, 1984).
As sweeper technology improved, so did the ability to pick up smaller particles that are readily available for washoff into nearby storm drains. Sutherland and Jelen (1997) reported simulated reductions of as much as 70 to 85 percent for average annual suspended solids and associated constituent loads with twice-weekly sweepings in a single-family residential neighborhood.

\section{Examination of Stormwater-Quality Concentrations and Loads}

Descriptive statistics for event mean concentrations and loads measured at the control, air, and high-frequency broom basins are summarized in tables 11 and 12. A complete list of event mean concentrations and loads can be found in tables 1-8 and 1-9 in appendix 1, respectively. Tables 1-8 and 1-9 also identify concentrations and loads measured when either the regenerative air or the vacuumassist sweeper was operated in the air-sweeper basin. Several samples collected over the course of the study were excluded from statistical analyses. Typically, these samples were censored because of inadequate hydrograph coverage, suspicion of contamination due to unforeseen basin changes (such as road construction), flushing of fire hydrants, or runoff due to snowmelt.

The variability in constituent loads monitored during the calibration and treatment phases is illustrated in figure 16. Given the variability observed in the load data, it is difficult to discern any differences between study phases. Median values for orthophosphorus appear to exhibit the most noticeable decrease during the treatment phase. However, it is difficult to attribute this decrease to street sweeping by visual inspection alone because the control basin showed a similar decrease. Any reductions identified in the control and test basins could be a result of some environmental factor other than street sweeping. In some cases, median sample constituent loads increased during the treatment phase. Median loads for dissolved copper and zinc increased in the high-frequency broom basin, as did total copper and total phosphorus in the air-sweeper basin. However, examination of the median fails to explain the variability of loads measured in each basin, therefore making it difficult to detect any significant difference between the calibration and treatment phases.

Constituent loads were tested for normality/log-normality by means of the Shapiro-Wilk test statistic (Helsel and Hirsch, 1992). Distributions of constituent loads in the basins during calibration and treatment phases were not consistently normal or lognormal. Therefore, examination 
Table 11a. Summary of water-quality concentrations in stormwater from the control and air-sweeper basins during calibration and treatment phases.

[ppb, parts per billion; ppm, parts per million]

\begin{tabular}{|c|c|c|c|c|c|c|}
\hline \multirow[b]{3}{*}{ Constituent } & \multicolumn{6}{|c|}{ Statistic, by type of basin or sweeper } \\
\hline & \multicolumn{3}{|c|}{ Number of samples } & \multicolumn{3}{|c|}{ Mean } \\
\hline & Control & \multicolumn{2}{|c|}{ Air sweeper } & Control & \multicolumn{2}{|c|}{ Air sweeper } \\
\hline \multicolumn{7}{|c|}{ Calibration phase } \\
\hline Cadmium, total (ppb) & 18 & \multicolumn{2}{|c|}{18} & 3.86 & \multicolumn{2}{|c|}{0.51} \\
\hline Copper, total (ppb) & 34 & \multicolumn{2}{|c|}{27} & 13.41 & \multicolumn{2}{|c|}{21.46} \\
\hline Lead, total (ppb) & 32 & \multicolumn{2}{|c|}{26} & 7.89 & \multicolumn{2}{|c|}{28.43} \\
\hline Zinc, total (ppb) & 34 & \multicolumn{2}{|c|}{27} & 65.92 & \multicolumn{2}{|c|}{122.85} \\
\hline Calcium, total (ppm) & 34 & \multicolumn{2}{|c|}{27} & 23.89 & \multicolumn{2}{|c|}{52.75} \\
\hline Magnesium, total (ppm) & 34 & \multicolumn{2}{|c|}{27} & 11.30 & \multicolumn{2}{|c|}{26.09} \\
\hline Ammonia-nitrogen (ppm) & 33 & \multicolumn{2}{|c|}{27} & 0.46 & \multicolumn{2}{|c|}{0.45} \\
\hline Phosphorus, total (ppm) & 34 & \multicolumn{2}{|c|}{27} & 0.91 & \multicolumn{2}{|c|}{0.88} \\
\hline Suspended sediment (ppm) & 34 & \multicolumn{2}{|c|}{27} & 469.01 & \multicolumn{2}{|c|}{$1,187.69$} \\
\hline Copper, dissolved (ppb) & 27 & \multicolumn{2}{|c|}{23} & 3.15 & \multicolumn{2}{|c|}{3.00} \\
\hline Zinc, dissolved (ppb) & 34 & \multicolumn{2}{|c|}{27} & 6.64 & \multicolumn{2}{|c|}{9.06} \\
\hline Orthophosphorus, dissolved (ppm) & 33 & 27 & & 0.19 & 0. & \\
\hline Solids, dissolved (ppm) & 34 & 27 & & 68.59 & 70. & \\
\hline Nitrate plus nitrite, dissolved (ppm) & 33 & 26 & & 0.48 & 0. & \\
\hline Constituent & Control & $\begin{array}{c}\text { Regenerative } \\
\text { air }\end{array}$ & $\begin{array}{c}\text { Vacuum } \\
\text { assist }\end{array}$ & Control & $\begin{array}{c}\text { Regenerative } \\
\quad \text { air }\end{array}$ & $\begin{array}{c}\text { Vacuum } \\
\text { assist }\end{array}$ \\
\hline & & atment phase & & & & \\
\hline Cadmium, total (ppb) & 19 & 8 & 8 & 2.08 & 0.30 & 0.23 \\
\hline Copper, total (ppb) & 35 & 13 & 21 & 20.04 & 20.23 & 13.94 \\
\hline Lead, total (ppb) & 34 & 13 & 21 & 11.84 & 17.71 & 11.97 \\
\hline Zinc, total (ppb) & 35 & 13 & 21 & 68.70 & 106.63 & 82.13 \\
\hline Calcium, total (ppm) & 35 & 13 & 21 & 40.17 & 52.88 & 19.94 \\
\hline Magnesium, total (ppm) & 35 & 13 & 21 & 19.51 & 25.22 & 9.30 \\
\hline Ammonia-nitrogen (ppm) & 35 & 13 & 21 & 0.56 & 0.59 & 0.47 \\
\hline Phosphorus, total (ppm) & 35 & 13 & 21 & 0.73 & 0.76 & 0.52 \\
\hline Suspended sediment (ppm) & 35 & 13 & 21 & 699.92 & 947.26 & 350.63 \\
\hline Copper, dissolved (ppb) & 27 & 12 & 15 & 4.00 & 4.36 & 2.89 \\
\hline Zinc, dissolved (ppb) & 35 & 13 & 21 & 7.04 & 19.61 & 7.33 \\
\hline Orthophosphorus, dissolved (ppm) & 34 & 13 & 20 & 0.18 & 0.16 & 0.18 \\
\hline Solids, dissolved (ppm) & 36 & 14 & 21 & 67.39 & 63.93 & 61.33 \\
\hline Nitrate plus nitrite, dissolved (ppm) & 36 & 14 & 21 & 0.49 & 0.44 & 0.48 \\
\hline
\end{tabular}




\begin{tabular}{|c|c|c|c|c|c|c|c|c|c|c|c|}
\hline \multicolumn{12}{|c|}{ Statistic, by type of basin or sweeper } \\
\hline \multicolumn{3}{|c|}{ Median } & \multicolumn{3}{|c|}{ Minimum } & \multicolumn{3}{|c|}{ Maximum } & \multicolumn{3}{|c|}{ Standard deviation } \\
\hline Control & \multicolumn{2}{|c|}{ Air sweeper } & Control & \multicolumn{2}{|c|}{ Air sweeper } & Control & \multicolumn{2}{|c|}{ Air sweeper } & Control & \multicolumn{2}{|c|}{ Air sweeper } \\
\hline \multicolumn{12}{|c|}{ Calibration phase } \\
\hline 0.30 & \multicolumn{2}{|c|}{0.40} & 0.03 & \multicolumn{2}{|c|}{0.05} & 59.90 & \multicolumn{2}{|c|}{18.00} & 14.03 & \multicolumn{2}{|c|}{0.35} \\
\hline 12.50 & \multicolumn{2}{|c|}{16.00} & 2.60 & \multicolumn{2}{|c|}{3.90} & 28.00 & \multicolumn{2}{|c|}{27.00} & 7.06 & \multicolumn{2}{|c|}{14.21} \\
\hline 5.25 & \multicolumn{2}{|c|}{17.00} & 0.96 & \multicolumn{2}{|c|}{2.30} & 22.00 & \multicolumn{2}{|c|}{26.00} & 5.34 & \multicolumn{2}{|c|}{35.37} \\
\hline 42.50 & \multicolumn{2}{|c|}{81.00} & 11.00 & \multicolumn{2}{|c|}{17.00} & 658.00 & \multicolumn{2}{|c|}{27.00} & 107.60 & \multicolumn{2}{|c|}{102.41} \\
\hline 16.00 & & & 5.40 & & 70 & 98.00 & & 00 & 22.10 & & 6.31 \\
\hline 6.75 & & & 2.00 & & 30 & 52.80 & & 00 & 11.59 & & 4.53 \\
\hline 0.51 & & 38 & 0.06 & & 04 & 0.91 & & 00 & 0.22 & & 0.25 \\
\hline 0.52 & & 75 & 0.15 & & 19 & 11.00 & & 74 & 1.87 & & 0.58 \\
\hline 234.00 & & & 39.00 & & & $3,394.00$ & 4,47 & & 617.43 & 1,2 & 2.72 \\
\hline 2.80 & & 50 & 1.40 & & 20 & 6.90 & & 00 & 1.44 & & 1.48 \\
\hline 5.95 & & 70 & 1.20 & & 70 & 21.00 & & 00 & 4.55 & & 7.21 \\
\hline 0.14 & & 16 & 0.06 & & 05 & 0.64 & & 87 & 0.13 & & 0.17 \\
\hline 57.50 & & 00 & 22.00 & & & 224.00 & & & 43.85 & & 9.54 \\
\hline 0.43 & & 41 & 0.24 & & 19 & 1.01 & & 01 & 0.18 & & 0.21 \\
\hline Control & $\begin{array}{l}\text { Regen- } \\
\text { erative } \\
\text { air }\end{array}$ & $\begin{array}{l}\text { Vacuum } \\
\text { assist }\end{array}$ & Control & $\begin{array}{c}\text { Regen- } \\
\text { erative } \\
\text { air }\end{array}$ & $\begin{array}{l}\text { Vacuum } \\
\text { assist }\end{array}$ & Control & $\begin{array}{l}\text { Regen- } \\
\text { erative } \\
\quad \text { air }\end{array}$ & $\begin{array}{c}\text { Vacuum } \\
\text { assist }\end{array}$ & Control & $\begin{array}{l}\text { Regen- } \\
\text { erative } \\
\text { air }\end{array}$ & $\begin{array}{c}\text { Vacuum } \\
\text { assist }\end{array}$ \\
\hline & & & & & Treat & ent phase & & & & & \\
\hline 0.25 & 0.29 & 0.22 & 0.11 & 0.21 & 0.04 & 34.00 & 0.48 & 0.47 & 7.73 & 0.08 & 0.14 \\
\hline 16.00 & 20.00 & 12.08 & 3.74 & 8.60 & 4.65 & 74.41 & 39.00 & 50.00 & 15.83 & 8.30 & 9.56 \\
\hline 8.41 & 16.00 & 8.70 & 1.60 & 3.40 & 3.50 & 36.61 & 33.00 & 39.00 & 9.10 & 10.63 & 8.78 \\
\hline 52.00 & 99.25 & 62.69 & 13.98 & 37.00 & 25.24 & 174.00 & 207.00 & 320.00 & 43.47 & 51.66 & 62.94 \\
\hline 19.34 & 34.55 & 15.36 & 4.93 & 8.30 & 4.83 & 206.76 & 152.00 & 98.00 & 47.19 & 44.52 & 20.15 \\
\hline 8.20 & 17.76 & 6.12 & 1.62 & 2.50 & 1.61 & 109.69 & 76.80 & 47.00 & 24.58 & 23.50 & 9.90 \\
\hline 0.49 & 0.53 & 0.32 & 0.08 & 0.26 & 0.14 & 2.32 & 1.17 & 1.74 & 0.41 & 0.26 & 0.38 \\
\hline 0.60 & 0.74 & 0.42 & 0.18 & 0.33 & 0.15 & 4.04 & 1.52 & 2.04 & 0.68 & 0.32 & 0.38 \\
\hline 261.19 & 873.67 & 264.11 & 36.00 & 102.00 & 35.00 & $3,359.65$ & $2,666.00$ & $1,196.00$ & 909.87 & 735.89 & 291.66 \\
\hline 3.80 & 3.20 & 2.60 & 1.40 & 1.80 & 1.50 & 12.00 & 14.00 & 5.60 & 2.26 & 3.32 & 1.05 \\
\hline 5.00 & 10.00 & 7.50 & 0.80 & 2.70 & 1.00 & 21.00 & 83.00 & 21.00 & 4.82 & 24.69 & 4.72 \\
\hline 0.13 & 0.14 & 0.13 & 0.04 & 0.07 & 0.05 & 0.68 & 0.30 & 0.68 & 0.13 & 0.08 & 0.15 \\
\hline 61.50 & 69.00 & 52.00 & 31.00 & 21.00 & 41.00 & 154.00 & 94.00 & 163.00 & 28.43 & 23.64 & 26.84 \\
\hline 0.41 & 0.37 & 0.41 & 0.27 & 0.15 & 0.26 & 1.43 & 0.89 & 1.20 & 0.25 & 0.21 & 0.22 \\
\hline
\end{tabular}


Table 11b. Summary of water-quality concentrations in stormwater from the control and high-frequency broom basins during calibration and treatment phases.

[ppb, parts per billion; ppm, parts per million]

\begin{tabular}{|c|c|c|c|c|}
\hline \multirow[b]{3}{*}{ Constituent } & \multicolumn{4}{|c|}{ Statistic, by type of basin or sweeper } \\
\hline & \multicolumn{2}{|c|}{ Number of samples } & \multicolumn{2}{|c|}{ Mean } \\
\hline & Control & $\begin{array}{l}\text { High-frequency } \\
\text { broom }\end{array}$ & Control & $\begin{array}{l}\text { High-frequency } \\
\text { broom }\end{array}$ \\
\hline \multicolumn{5}{|c|}{ Calibration phase } \\
\hline Cadmium, total (ppb) & 21 & 10 & 3.35 & 0.44 \\
\hline Copper, total (ppb) & 41 & 23 & 14.17 & 27.28 \\
\hline Lead, total (ppb) & 39 & 22 & 8.86 & 12.79 \\
\hline Zinc, total (ppb) & 41 & 23 & 69.22 & 162.56 \\
\hline Calcium, total (ppm) & 41 & 23 & 24.21 & 56.89 \\
\hline Magnesium, total (ppm) & 41 & 23 & 11.32 & 28.67 \\
\hline Ammonia-nitrogen (ppm) & 40 & 21 & 0.55 & 0.51 \\
\hline Phosphorus, total (ppm) & 41 & 23 & 0.87 & 0.88 \\
\hline Suspended sediment (ppm) & 41 & 23 & 444.38 & $1,387.02$ \\
\hline Copper, dissolved (ppb) & 32 & 20 & 3.11 & 3.25 \\
\hline Zinc, dissolved (ppb) & 41 & 23 & 6.72 & 8.01 \\
\hline Orthophosphorus, dissolved (ppm) & 40 & 23 & 0.19 & 0.23 \\
\hline Solids, dissolved (ppm) & 41 & 23 & 69.02 & 61.61 \\
\hline Nitrate plus nitrite, dissolved (ppm) & 40 & 22 & 0.52 & 0.53 \\
\hline \multicolumn{5}{|c|}{ Treatment phase } \\
\hline Cadmium, total (ppb) & 16 & 6 & 2.42 & 0.31 \\
\hline Copper, total (ppb) & 28 & 24 & 20.58 & 46.08 \\
\hline Lead, total (ppb) & 27 & 23 & 11.45 & 24.28 \\
\hline Zinc, total (ppb) & 28 & 24 & 64.56 & 143.83 \\
\hline Calcium, total (ppm) & 28 & 24 & 43.78 & 107.93 \\
\hline Magnesium, total (ppm) & 28 & 24 & 21.52 & 52.11 \\
\hline Ammonia-nitrogen (ppm) & 28 & 24 & 0.46 & 0.41 \\
\hline Phosphorus, total (ppm) & 28 & 24 & 0.74 & 0.80 \\
\hline Suspended sediment (ppm) & 28 & 25 & 793.71 & $2,246.91$ \\
\hline Copper, dissolved (ppb) & 22 & 21 & 4.25 & 4.00 \\
\hline Zinc, dissolved (ppb) & 28 & 24 & 7.03 & 10.30 \\
\hline Orthophosphorus, dissolved (ppm) & 27 & 24 & 0.17 & 0.18 \\
\hline Solids, dissolved (ppm) & 29 & 25 & 66.48 & 58.44 \\
\hline Nitrate plus nitrite, dissolved (ppm) & 29 & 25 & 0.43 & 0.41 \\
\hline
\end{tabular}




\begin{tabular}{|c|c|c|c|c|c|c|c|}
\hline \multicolumn{8}{|c|}{ Statistic, by type of basin or sweeper } \\
\hline \multicolumn{2}{|c|}{ Median } & \multicolumn{2}{|c|}{ Minimum } & \multicolumn{2}{|c|}{ Maximum } & \multicolumn{2}{|c|}{ Standard deviation } \\
\hline Control & $\begin{array}{l}\text { High-frequency } \\
\text { broom }\end{array}$ & Control & $\begin{array}{c}\text { High-frequency } \\
\text { broom }\end{array}$ & Control & $\begin{array}{l}\text { High-frequency } \\
\text { broom }\end{array}$ & Control & $\begin{array}{c}\text { High-frequency } \\
\text { broom }\end{array}$ \\
\hline \multicolumn{8}{|c|}{ Calibration phase } \\
\hline 0.30 & 0.23 & 0.03 & 0.09 & 59.90 & 1.54 & 13.00 & 0.45 \\
\hline 12.00 & 19.00 & 2.60 & 5.40 & 34.77 & 162.80 & 8.04 & 31.89 \\
\hline 6.52 & 7.71 & 0.96 & 1.70 & 22.32 & 42.21 & 6.07 & 10.94 \\
\hline 43.00 & 79.32 & 11.00 & 33.00 & 658.00 & $1,183.69$ & 100.59 & 270.34 \\
\hline 16.00 & 19.70 & 5.40 & 8.40 & 98.00 & 521.74 & 21.19 & 108.76 \\
\hline 6.40 & 7.90 & 2.00 & 2.70 & 52.80 & 263.97 & 11.05 & 56.04 \\
\hline 0.53 & 0.44 & 0.06 & 0.13 & 2.32 & 1.22 & 0.37 & 0.26 \\
\hline 0.51 & 0.80 & 0.15 & 0.34 & 11.00 & 3.18 & 1.71 & 0.59 \\
\hline 230.00 & 541.00 & 39.00 & 121.00 & $3,394.00$ & $13,472.70$ & 571.02 & $2,822.55$ \\
\hline 2.85 & 2.45 & 1.40 & 1.30 & 6.90 & 15.00 & 1.37 & 2.94 \\
\hline 5.90 & 5.70 & 1.20 & 1.30 & 21.00 & 35.00 & 4.53 & 7.54 \\
\hline 0.14 & 0.17 & 0.04 & 0.07 & 0.68 & 0.67 & 0.14 & 0.15 \\
\hline 58.00 & 58.00 & 22.00 & 32.00 & 224.00 & 98.00 & 42.71 & 20.14 \\
\hline 0.45 & 0.48 & 0.24 & 0.25 & 1.43 & 1.10 & 0.24 & 0.20 \\
\hline \multicolumn{8}{|c|}{ Treatment phase } \\
\hline 0.26 & 0.25 & 0.11 & 0.21 & 34.00 & 0.49 & 8.42 & 0.12 \\
\hline 16.00 & 12.35 & 3.74 & 5.80 & 74.41 & 785.07 & 16.84 & 157.59 \\
\hline 7.83 & 6.60 & 1.60 & 0.07 & 36.61 & 350.09 & 9.55 & 71.73 \\
\hline 55.26 & 56.50 & 13.98 & 23.74 & 152.42 & $1,965.27$ & 39.15 & 390.26 \\
\hline 20.17 & 10.80 & 4.93 & 5.60 & 206.76 & $1,972.48$ & 51.67 & 399.20 \\
\hline 8.65 & 5.05 & 1.62 & 1.73 & 109.69 & 971.98 & 26.89 & 196.89 \\
\hline 0.36 & 0.30 & 0.08 & 0.06 & 1.27 & 1.26 & 0.27 & 0.33 \\
\hline 0.61 & 0.44 & 0.18 & 0.17 & 4.04 & 7.03 & 0.72 & 1.36 \\
\hline 270.60 & 262.00 & 36.00 & 26.00 & $3,359.65$ & $41,418.42$ & 992.09 & $8,238.95$ \\
\hline 4.05 & 3.40 & 1.40 & 1.60 & 12.00 & 13.00 & 2.40 & 2.50 \\
\hline 4.95 & 9.30 & 0.80 & 1.30 & 21.00 & 25.00 & 4.91 & 6.05 \\
\hline 0.13 & 0.16 & 0.07 & 0.09 & 0.53 & 0.66 & 0.10 & 0.12 \\
\hline 64.00 & 62.00 & 31.00 & 20.00 & 146.00 & 100.00 & 25.84 & 18.79 \\
\hline 0.39 & 0.36 & 0.27 & 0.24 & 0.95 & 0.70 & 0.16 & 0.13 \\
\hline
\end{tabular}


Table 12a. Summary of loads in the control and air-sweeper basins during calibration and treatment phases.

\begin{tabular}{|c|c|c|c|c|c|c|}
\hline \multirow[b]{3}{*}{ Constituent } & \multicolumn{6}{|c|}{ Statistic, by type of basin or sweeper } \\
\hline & \multicolumn{3}{|c|}{ Number of samples } & \multicolumn{3}{|c|}{ Mean } \\
\hline & Control & \multicolumn{2}{|c|}{ Air sweeper } & Control & \multicolumn{2}{|c|}{ Air sweeper } \\
\hline \multicolumn{7}{|c|}{ Calibration phase } \\
\hline Cadmium, total (grams) & 18 & \multicolumn{2}{|c|}{18} & 5.23 & \multicolumn{2}{|c|}{0.38} \\
\hline Copper, total (grams) & 34 & \multicolumn{2}{|c|}{27} & 11.86 & \multicolumn{2}{|c|}{15.35} \\
\hline Lead, total (grams) & 32 & \multicolumn{2}{|c|}{26} & 7.74 & \multicolumn{2}{|c|}{17.69} \\
\hline Zinc, total (grams) & 34 & \multicolumn{2}{|c|}{27} & 66.90 & \multicolumn{2}{|c|}{80.28} \\
\hline Calcium, total (kilograms) & 34 & \multicolumn{2}{|c|}{34} & 23.25 & \multicolumn{2}{|c|}{30.76} \\
\hline Magnesium, total (kilograms) & 34 & \multicolumn{2}{|c|}{27} & 11.13 & \multicolumn{2}{|c|}{19.73} \\
\hline Ammonia-nitrogen (kilograms) & 33 & \multicolumn{2}{|c|}{27} & 0.40 & \multicolumn{2}{|c|}{0.28} \\
\hline Phosphorus, total (kilograms) & 34 & \multicolumn{2}{|c|}{27} & 0.88 & \multicolumn{2}{|c|}{0.57} \\
\hline Suspended sediment (kilograms) & 34 & \multicolumn{2}{|c|}{27} & 485.87 & \multicolumn{2}{|c|}{906.93} \\
\hline Copper, dissolved (grams) & 27 & \multicolumn{2}{|c|}{23} & 2.60 & \multicolumn{2}{|c|}{1.62} \\
\hline Zinc, dissolved (grams) & 34 & \multicolumn{2}{|c|}{27} & 5.44 & \multicolumn{2}{|c|}{4.75} \\
\hline Orthophosphorus, dissolved (kilograms) & 33 & 27 & & 0.14 & & \\
\hline Solids, dissolved (kilograms) & 34 & 27 & & 74.21 & 39. & \\
\hline Nitrate plus nitrite, dissolved (kilograms) & 33 & 26 & & 0.43 & & \\
\hline Constituent & Control & $\begin{array}{l}\text { Regenerative } \\
\text { air }\end{array}$ & $\begin{array}{c}\text { Vacuum } \\
\text { assist }\end{array}$ & Control & $\begin{array}{l}\text { Regenerative } \\
\text { air }\end{array}$ & $\begin{array}{c}\text { Vacuum } \\
\text { assist }\end{array}$ \\
\hline & & atment phase & & & & \\
\hline Cadmium, total (grams) & 19 & 8 & 8 & 1.11 & 0.21 & 0.10 \\
\hline Copper, total (grams) & 35 & 13 & 21 & 10.60 & 11.95 & 6.04 \\
\hline Lead, total (grams) & 34 & 13 & 21 & 6.25 & 11.33 & 6.14 \\
\hline Zinc, total (grams) & 35 & 13 & 21 & 35.11 & 59.00 & 33.48 \\
\hline Calcium, total (kilograms) & 35 & 13 & 22 & 22.49 & 30.52 & 8.15 \\
\hline Magnesium, total (kilograms) & 35 & 13 & 21 & 11.08 & 14.73 & 4.16 \\
\hline Ammonia-nitrogen (kilograms) & 35 & 13 & 21 & 0.26 & 0.32 & 0.18 \\
\hline Phosphorus, total (kilograms) & 35 & 13 & 21 & 0.38 & 0.41 & 0.21 \\
\hline Suspended sediment (kilograms) & 35 & 13 & 21 & 410.82 & 668.57 & 181.56 \\
\hline Copper, dissolved (grams) & 27 & 12 & 15 & 1.90 & 3.59 & 1.10 \\
\hline Zinc, dissolved (grams) & 35 & 13 & 21 & 3.24 & 18.48 & 2.45 \\
\hline Orthophosphorus, dissolved (kilograms) & 34 & 13 & 20 & 0.07 & 0.09 & 0.06 \\
\hline Solids, dissolved (kilograms) & 36 & 14 & 21 & 30.34 & 29.90 & 24.23 \\
\hline Nitrate plus nitrite, dissolved (kilograms) & 36 & 14 & 21 & 0.22 & 0.22 & 0.18 \\
\hline
\end{tabular}




\begin{tabular}{|c|c|c|c|c|c|c|c|c|c|c|c|}
\hline \multicolumn{12}{|c|}{ Statistic, by type of basin or sweeper } \\
\hline \multicolumn{3}{|c|}{ Median } & \multicolumn{3}{|c|}{ Minimum } & \multicolumn{3}{|c|}{ Maximum } & \multicolumn{3}{|c|}{ Standard deviation } \\
\hline Control & \multicolumn{2}{|c|}{ Air sweeper } & Control & \multicolumn{2}{|c|}{ Air sweeper } & Control & \multicolumn{2}{|c|}{ Air sweeper } & Control & \multicolumn{2}{|c|}{ Air sweeper } \\
\hline \multicolumn{12}{|c|}{ Calibration phase } \\
\hline 0.25 & \multicolumn{2}{|c|}{0.24} & 0.02 & \multicolumn{2}{|c|}{0.03} & 83.38 & \multicolumn{2}{|c|}{18.00} & 19.57 & \multicolumn{2}{|c|}{0.45} \\
\hline 8.65 & \multicolumn{2}{|c|}{6.39} & 1.39 & \multicolumn{2}{|c|}{1.39} & 38.98 & \multicolumn{2}{|c|}{27.00} & 9.78 & \multicolumn{2}{|c|}{21.27} \\
\hline 5.22 & \multicolumn{2}{|c|}{6.21} & 0.24 & \multicolumn{2}{|c|}{1.05} & 30.63 & \multicolumn{2}{|c|}{26.00} & 7.54 & \multicolumn{2}{|c|}{23.23} \\
\hline 32.49 & \multicolumn{2}{|c|}{48.67} & 5.67 & \multicolumn{2}{|c|}{6.11} & 931.14 & \multicolumn{2}{|c|}{27.00} & 155.83 & \multicolumn{2}{|c|}{107.05} \\
\hline 12.18 & & 97 & 1.50 & & 00 & 155.45 & & & 30.00 & & 2.94 \\
\hline 5.85 & & 26 & 0.56 & & 64 & 75.16 & & & 14.90 & & 0.22 \\
\hline 0.35 & & 19 & 0.06 & & 02 & 1.06 & & 34 & 0.28 & & 0.28 \\
\hline 0.40 & & 21 & 0.08 & & 05 & 15.57 & & 66 & 2.61 & & 0.75 \\
\hline 200.78 & & & 18.89 & & & $5,606.81$ & 556 & & 970.05 & 1,3 & 9.12 \\
\hline 2.29 & & 13 & 0.50 & & 24 & 10.08 & & 54 & 1.97 & & 1.19 \\
\hline 3.43 & & 26 & 0.79 & & 78 & 24.78 & & & 4.74 & & 4.56 \\
\hline 0.12 & & 11 & 0.03 & & 02 & 0.31 & & 39 & 0.08 & & 0.09 \\
\hline 42.39 & & & 9.95 & & 19 & 658.19 & & & 120.14 & & 0.42 \\
\hline 0.31 & & 27 & 0.04 & & 04 & 1.74 & & 68 & 0.34 & & 0.17 \\
\hline Control & $\begin{array}{l}\text { Regen- } \\
\text { erative } \\
\text { air }\end{array}$ & $\begin{array}{c}\text { Vacuum } \\
\text { assist }\end{array}$ & Control & $\begin{array}{c}\text { Regen- } \\
\text { erative } \\
\text { air }\end{array}$ & $\begin{array}{l}\text { Vacuum } \\
\text { assist }\end{array}$ & Control & $\begin{array}{l}\text { Regen- } \\
\text { erative } \\
\quad \text { air }\end{array}$ & $\begin{array}{c}\text { Vacuum } \\
\text { assist }\end{array}$ & Control & $\begin{array}{l}\text { Regen- } \\
\text { erative } \\
\text { air }\end{array}$ & $\begin{array}{c}\text { Vacuum } \\
\text { assist }\end{array}$ \\
\hline & & & & & Treatr & ent phase & & & & & \\
\hline 0.13 & 0.19 & 0.10 & 0.03 & 0.07 & 0.01 & 17.50 & 0.54 & 0.16 & 3.98 & 0.14 & 0.05 \\
\hline 5.44 & 10.72 & 5.05 & 1.21 & 2.15 & 0.56 & 77.19 & 31.16 & 16.64 & 13.73 & 8.27 & 4.81 \\
\hline 3.98 & 9.59 & 3.53 & 0.45 & 0.61 & 0.48 & 26.58 & 30.10 & 33.82 & 6.18 & 9.51 & 7.59 \\
\hline 24.79 & 56.30 & 29.22 & 4.31 & 9.67 & 3.04 & 133.23 & 120.47 & 80.74 & 29.78 & 35.65 & 24.10 \\
\hline 6.65 & 22.53 & 5.77 & 1.34 & 2.04 & 0.00 & 142.94 & 86.60 & 23.82 & 33.44 & 29.12 & 7.60 \\
\hline 2.99 & 10.05 & 2.82 & 0.48 & 0.57 & 0.19 & 71.79 & 41.96 & 12.66 & 17.46 & 14.79 & 4.01 \\
\hline 0.23 & 0.30 & 0.16 & 0.02 & 0.05 & 0.03 & 0.79 & 0.73 & 0.43 & 0.19 & 0.19 & 0.12 \\
\hline 0.24 & 0.45 & 0.21 & 0.04 & 0.09 & 0.02 & 2.94 & 0.75 & 0.68 & 0.50 & 0.21 & 0.16 \\
\hline 118.65 & 413.59 & 102.80 & 9.21 & 16.73 & 4.21 & $3,104.03$ & $2,523.73$ & 673.33 & 664.41 & 726.64 & 202.17 \\
\hline 1.97 & 1.20 & 0.82 & 0.56 & 0.55 & 0.28 & 3.77 & 26.29 & 4.11 & 0.96 & 7.21 & 1.01 \\
\hline 3.03 & 4.17 & 1.84 & 0.09 & 1.16 & 0.82 & 8.37 & 118.30 & 6.27 & 2.23 & 36.01 & 1.64 \\
\hline 0.07 & 0.08 & 0.06 & 0.01 & 0.02 & 0.01 & 0.22 & 0.24 & 0.15 & 0.04 & 0.07 & 0.04 \\
\hline 24.86 & 30.45 & 20.71 & 6.91 & 8.14 & 7.54 & 74.88 & 55.78 & 55.38 & 17.40 & 14.42 & 14.85 \\
\hline 0.20 & 0.23 & 0.20 & 0.04 & 0.04 & 0.03 & 0.62 & 0.62 & 0.45 & 0.13 & 0.15 & 0.10 \\
\hline
\end{tabular}


Table 12b. Summary of loads in the control and high-frequency broom basins during calibration and treatment phases.

\begin{tabular}{|c|c|c|c|c|}
\hline \multirow[b]{3}{*}{ Constituent } & \multicolumn{4}{|c|}{ Statistic, by type of basin or sweeper } \\
\hline & \multicolumn{2}{|c|}{ Number of samples } & \multicolumn{2}{|c|}{ Mean } \\
\hline & Control & $\begin{array}{l}\text { High-frequency } \\
\text { broom }\end{array}$ & Control & $\begin{array}{l}\text { High-frequency } \\
\text { broom }\end{array}$ \\
\hline \multicolumn{5}{|c|}{ Calibration phase } \\
\hline Cadmium, total, in grams & 21 & 10 & 4.51 & 0.34 \\
\hline Copper, total, in grams & 41 & 23 & 11.18 & 43.01 \\
\hline Lead, total, in grams & 39 & 22 & 7.50 & 9.35 \\
\hline Zinc, total, in grams & 41 & 23 & 61.71 & 146.08 \\
\hline Calcium, total, in kilograms & 41 & 23 & 21.43 & 43.01 \\
\hline Magnesium, total, in kilograms & 41 & 23 & 10.21 & 22.41 \\
\hline Ammonia-Nitrogen, in kilograms & 40 & 21 & 0.40 & 0.32 \\
\hline Phosphorus, total, in kilograms & 41 & 23 & 0.78 & 0.57 \\
\hline Suspended sediment, in kilograms & 41 & 23 & 429.00 & $1,076.20$ \\
\hline Copper, dissolved, in grams & 32 & 20 & 2.41 & 1.82 \\
\hline Zinc, dissolved, in grams & 41 & 23 & 5.02 & 4.08 \\
\hline Orthophosphorus, dissolved, in kilograms & 40 & 23 & 0.13 & 0.13 \\
\hline Solids, dissolved, in kilograms & 41 & 23 & 67.00 & 39.79 \\
\hline Nitrate plus nitrite, dissolved, in kilograms & 40 & 22 & 0.41 & 0.33 \\
\hline \multicolumn{5}{|c|}{ Treatment phase } \\
\hline Cadmium, total, in grams & 16 & 6 & 1.30 & 0.13 \\
\hline Copper, total, in grams & 28 & 24 & 11.27 & 16.20 \\
\hline Lead, total, in grams & 27 & 23 & 6.20 & 9.61 \\
\hline Zinc, total, in grams & 28 & 24 & 34.76 & 51.31 \\
\hline Calcium, total, in kilograms & 28 & 24 & 24.97 & 36.67 \\
\hline Magnesium, total, in kilograms & 28 & 24 & 12.41 & 17.63 \\
\hline Ammonia-Nitrogen, in kilograms & 28 & 24 & 0.23 & 0.16 \\
\hline Phosphorus, total, in kilograms & 28 & 24 & 0.40 & 0.30 \\
\hline Suspended sediment, in kilograms & 28 & 25 & 475.34 & 761.71 \\
\hline Copper, dissolved, in grams & 22 & 21 & 2.01 & 1.63 \\
\hline Zinc, dissolved, in grams & 28 & 24 & 3.31 & 4.19 \\
\hline Orthophosphorus, dissolved, in kilograms & 27 & 24 & 0.07 & 0.07 \\
\hline Solids, dissolved, in kilograms & 29 & 25 & 29.94 & 22.80 \\
\hline Nitrate plus nitrite, dissolved, in kilograms & 29 & 25 & 0.20 & 0.16 \\
\hline
\end{tabular}




\begin{tabular}{|c|c|c|c|c|c|c|c|}
\hline \multicolumn{8}{|c|}{ Statistic, by type of basin or sweeper } \\
\hline \multicolumn{2}{|c|}{ Median } & \multicolumn{2}{|c|}{ Minimum } & \multicolumn{2}{|c|}{ Maximum } & \multicolumn{2}{|c|}{ Standard Deviation } \\
\hline Control & $\begin{array}{l}\text { High-frequency } \\
\text { broom }\end{array}$ & Control & $\begin{array}{c}\text { High-frequency } \\
\text { broom }\end{array}$ & Control & $\begin{array}{l}\text { High-frequency } \\
\text { broom }\end{array}$ & Control & $\begin{array}{c}\text { High-frequency } \\
\text { broom }\end{array}$ \\
\hline \multicolumn{8}{|c|}{ Calibration phase } \\
\hline 0.21 & 0.17 & 0.02 & 0.02 & 83.38 & 1.31 & 18.14 & 0.42 \\
\hline 7.51 & 10.08 & 1.39 & 1.88 & 38.98 & 301.12 & 9.27 & 77.14 \\
\hline 5.19 & 5.61 & 0.24 & 0.66 & 30.63 & 38.18 & 7.22 & 10.01 \\
\hline 31.94 & 38.99 & 5.67 & 10.57 & 931.14 & $1,796.68$ & 142.32 & 372.68 \\
\hline 10.78 & 10.08 & 1.50 & 1.88 & 155.45 & 301.12 & 28.03 & 77.14 \\
\hline 5.12 & 4.85 & 0.56 & 0.57 & 75.16 & 152.35 & 13.95 & 41.41 \\
\hline 0.35 & 0.25 & 0.06 & 0.04 & 1.06 & 1.40 & 0.27 & 0.28 \\
\hline 0.37 & 0.41 & 0.08 & 0.10 & 15.57 & 2.04 & 2.38 & 0.54 \\
\hline 187.35 & 185.87 & 18.89 & 25.34 & $5,606.81$ & $7,775.73$ & 892.15 & $2,031.23$ \\
\hline 2.16 & 1.22 & 0.50 & 0.54 & 10.08 & 7.36 & 1.89 & 1.67 \\
\hline 3.07 & 3.00 & 0.79 & 0.70 & 24.78 & 14.53 & 4.45 & 3.35 \\
\hline 0.11 & 0.11 & 0.01 & 0.02 & 0.31 & 0.56 & 0.08 & 0.11 \\
\hline 35.74 & 30.13 & 9.95 & 6.34 & 658.19 & 168.76 & 110.56 & 34.89 \\
\hline 0.31 & 0.28 & 0.04 & 0.09 & 1.74 & 1.02 & 0.32 & 0.21 \\
\hline \multicolumn{8}{|c|}{ Treatment phase } \\
\hline 0.13 & 0.13 & 0.03 & 0.05 & 17.50 & 0.20 & 4.33 & 0.05 \\
\hline 5.54 & 6.37 & 1.21 & 0.69 & 77.19 & 251.09 & 15.09 & 50.21 \\
\hline 3.30 & 3.73 & 0.45 & 0.01 & 26.58 & 111.97 & 6.36 & 23.57 \\
\hline 23.17 & 26.06 & 4.31 & 3.63 & 133.23 & 628.56 & 31.41 & 124.16 \\
\hline 6.89 & 6.34 & 1.34 & 0.70 & 142.94 & 630.87 & 36.56 & 127.26 \\
\hline 3.24 & 2.69 & 0.48 & 0.26 & 71.79 & 310.87 & 19.07 & 62.79 \\
\hline 0.18 & 0.11 & 0.02 & 0.01 & 0.63 & 0.43 & 0.17 & 0.13 \\
\hline 0.25 & 0.23 & 0.04 & 0.02 & 2.94 & 2.25 & 0.55 & 0.44 \\
\hline 146.14 & 117.08 & 9.21 & 5.09 & $3,104.03$ & $13,247.04$ & 727.39 & $2,624.04$ \\
\hline 2.06 & 1.28 & 0.63 & 0.15 & 3.77 & 5.33 & 0.97 & 1.31 \\
\hline 3.14 & 3.22 & 0.09 & 0.47 & 8.37 & 16.53 & 2.39 & 3.68 \\
\hline 0.07 & 0.05 & 0.01 & 0.01 & 0.22 & 0.18 & 0.05 & 0.04 \\
\hline 23.09 & 18.08 & 6.91 & 4.29 & 63.28 & 71.11 & 17.16 & 15.21 \\
\hline 0.18 & 0.16 & 0.04 & 0.03 & 0.62 & 0.38 & 0.13 & 0.09 \\
\hline
\end{tabular}



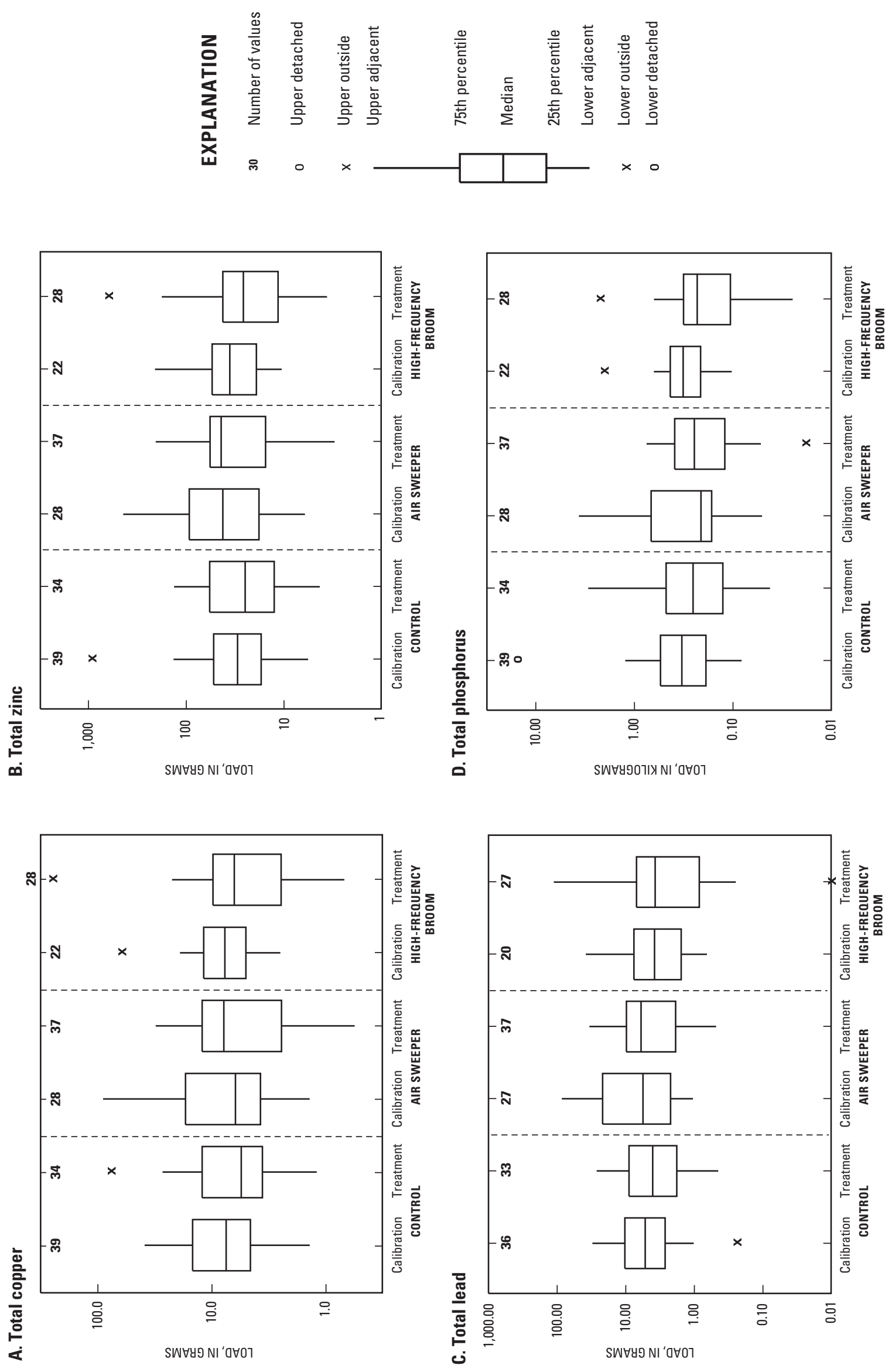

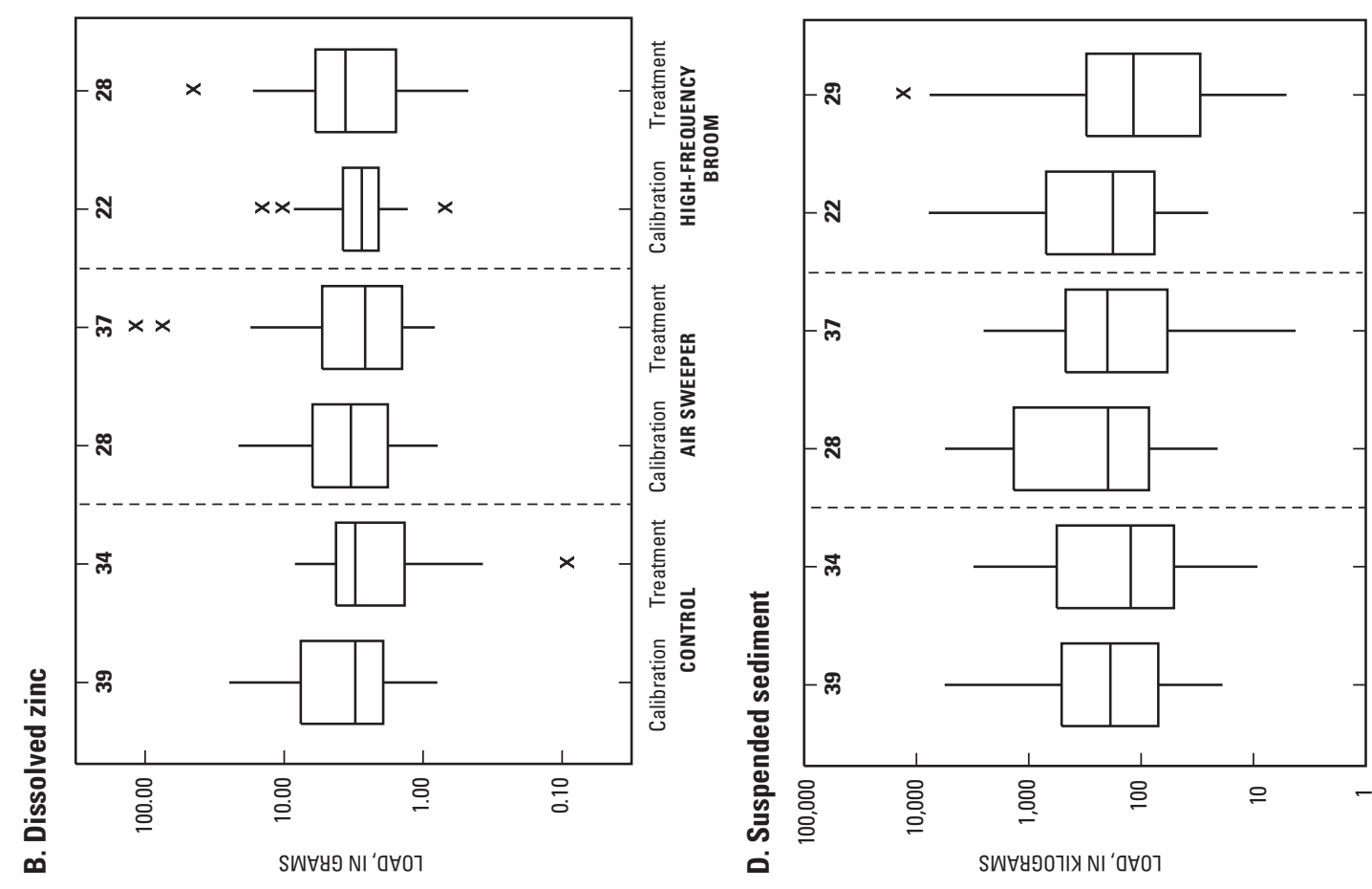
of constituent loads made use of nonparametric statistical tests because no assumptions about how the data are distributed are necessary (Helsel and Hirsch, 1992).

The Wilcoxon rank-sum test (Helsel and Hirsch, 1992) was used to assess the distribution of the data and to ultimately determine whether the contribution of loads significantly changed as a result of street sweeping. The null hypothesis states there is no difference in the distribution of loads for the particular test basin between the calibration and treatment phases. The alternative hypothesis is that there is a significant difference and that we can infer this difference is a result of street sweeping. Table 13 lists the probabilities, as percentages, associated with the Wilcoxon rank-sum statistic for stormwater-quality constituent and sweeper type. Higher percentages indicate greater likelihood that the distributions of calibration and treatment loads do not differ, whereas very low percentages indicate that the distributions are different. (For example, the probability for cadmium loads for the regenerative-air sweeper was calculated to be 92 percent (table 13); therefore, there appears to be no change in total cadmium load as a result of sweeping with a regenerative-air street sweeper.) For those constituent loads whose probability percentages were very low and for which the null hypothesis was rejected, additional testing was done to determine whether there was a significant increase or decrease as a result of street sweeping (indicated by either upward- or downward-facing arrows in table 13).

The majority of constituent loads did not differ significantly in magnitude from calibration to treatment phases. The high-frequency broom basin showed significant differences (at the 10-percent level) in load from the calibration to treatment phase for total copper, zinc, phosphorus, and suspended sediment. Further evaluation indicated a pattern of lower observations in load for these constituents during the treatment phase. Load data corresponding to both the regenerative-air and vacuum-assist sweepers also showed significant differences for some of the dissolved constituents between study phases. However, the observations during the treatment phase tended to be higher than those during the calibration phase.

Table 13. Probabilities that there is no difference in storm-runoff loads between calibration and treatment phases for the regenerative-air, vacuum-assist, and high-frequency broom sweepers. Direction of arrows indicates an increase or decrease in load due to street sweeping.

[probabilities are expressed as percent; the smaller the probability, the stronger the statistical significance]

\begin{tabular}{|c|c|c|c|}
\hline \multirow[b]{2}{*}{ Constituent } & \multicolumn{3}{|c|}{ Street sweeper type } \\
\hline & Regenerative air & Vacuum assist & $\begin{array}{c}\text { High-frequency } \\
\text { broom }\end{array}$ \\
\hline Cadmium, total & 92 & 59 & 93 \\
\hline Copper, total & 84 & 44 & $10 \downarrow$ \\
\hline Lead, total & 49 & 49 & 43 \\
\hline Zinc, total & 35 & 92 & $3 \downarrow$ \\
\hline Calcium, total & 13 & 94 & 27 \\
\hline Magnesium, total & 11 & 99 & 20 \\
\hline Ammonia-nitrogen & 18 & $<1 \uparrow$ & 88 \\
\hline Phosphorus, total & 69 & 68 & $7 \downarrow$ \\
\hline Suspended sediment & 14 & 84 & $1 \downarrow$ \\
\hline Copper, dissolved & 21 & $<1 \uparrow$ & 17 \\
\hline Zinc, dissolved & 94 & 82 & 55 \\
\hline Orthophosphorus, dissolved & $10 \uparrow$ & 12 & 47 \\
\hline Chloride, dissolved & 22 & $3 \uparrow$ & 47 \\
\hline Nitrate plus nitrite, dissolved & $5 \uparrow$ & $<1 \uparrow$ & 38 \\
\hline Number of samples & 13 & 20 & 24 \\
\hline
\end{tabular}


For those constituent loads that fit a log-normal distribution, an analysis of covariance (ANCOVA) was done to determine whether the linear relation between control and test-basin loads during the treatment phase is significantly different from that during the calibration phase. If the result of the test was significant, the magnitude of change in average constituent load could then be quantified. Of the significant changes identified in table 13, only ammonia-nitrogen for the vacuum-assist sweeper phase in the air-sweeper basin showed significant differences at the 10-percent significance level. The degree of change was then quantified by calculating the percentage increase or decrease in the original, untransformed, average loads. For the vacuum-assist sweeper in the air-sweeper basin, increases in ammonia-nitrogen of 63 percent were recorded.

Inconsistencies in the statistical results detailed in table 13 cannot be easily explained. Numerous trace metals and other urban runoff constituents exhibit a strong association to sediment (Horowitz, 1985; German and Svensson, 2002). Therefore, one might expect to see trace-metal loads change in a similar pattern as suspendedsediment loads. Only the high-frequency broom basin exhibited an association of trace metals to sediment by showing reductions in total copper and zinc loads, as well as suspended-sediment load, at the 10-percent significance level. However, total calcium and magnesium, two elements that are strongly related to street sediments, showed no significant reductions. One explanation for these inconsistencies is the large amount of variability inherent in the constituent-load data.

An examination of the coefficient of variation (COV) is one way to quantify the variability of data. Table 14 details the COVs for the control and test basins during the calibration and treatment phases for each constituent load listed in table 13. A low COV value indicates a much smaller spread of data compared to a data set having a large COV value (Burton and Pitt, 2002). Several of the COVs in table 14 are greater than 1 , indicating substantial variability in loads within the basin. Much of the variability could be a function of an insufficient number of paired samples collected to result in statistically relevant conclusions. Burton and Pitt (2002) describe methods to estimate the number of samples necessary to adequately describe the conditions to be tested given the COV of the data sets, an allowable error, and the degree of confidence and power for each parameter. For example, given a COV of 1.5 for suspended sediment during the calibration phase in the airsweeper basin, and assuming a 95-percent confidence level and power of 0.5 (the larger the power, the less probable

Table 14. Coefficient of variation for constituent loads measured in stormwater from the control and test basins during the calibration and treatment phases.

\begin{tabular}{|c|c|c|c|c|c|}
\hline \multirow[b]{3}{*}{ Constituent } & \multicolumn{5}{|c|}{ Test basin and phase of study } \\
\hline & \multirow{2}{*}{$\begin{array}{l}\text { Air sweeper } \\
\text { Calibration }\end{array}$} & \multirow{2}{*}{$\begin{array}{c}\begin{array}{c}\text { Air sweeper } \\
\text { (regenerative air) }\end{array} \\
\text { Treatment }\end{array}$} & \multirow{2}{*}{$\begin{array}{c}\begin{array}{c}\text { Air sweeper } \\
\text { (vacuum assist) }\end{array} \\
\text { Treatment }\end{array}$} & \multicolumn{2}{|c|}{ High-frequency broom } \\
\hline & & & & Calibration & Treatment \\
\hline Cadmium, total & 1.2 & 0.8 & 0.7 & 0.6 & 0.9 \\
\hline Copper, total & 1.4 & .7 & .8 & 1.1 & 3.0 \\
\hline Lead, total & 1.4 & .9 & 1.2 & 1.3 & 2.5 \\
\hline Zinc, total & 1.4 & .8 & .7 & 1.0 & 2.2 \\
\hline Calcium, total & 1.5 & 1.0 & .8 & 1.3 & 2.9 \\
\hline Magnesium, total & 1.5 & 1.0 & .9 & 1.4 & 3.0 \\
\hline Ammonia-nitrogen & 1.0 & 6 & .7 & 1.0 & .8 \\
\hline Phosphorus, total & 1.3 & .5 & .7 & 1.0 & 1.4 \\
\hline Suspended sediment & 1.5 & 1.1 & 1.0 & 2.1 & 2.9 \\
\hline Copper, dissolved & .8 & 1.9 & 1.2 & 1.0 & 1.3 \\
\hline Zinc, dissolved & 1.0 & 2.0 & 1.1 & .9 & 1.5 \\
\hline Orthophosphorus, dissolved & .7 & .7 & 6 & .9 & .7 \\
\hline Chloride, dissolved & 1.6 & 6 & .7 & 1.7 & .7 \\
\hline Nitrate plus nitrite, dissolved & 6 & .7 & .5 & .7 & 6 \\
\hline
\end{tabular}


the experimental result is due to chance) approximately 200 paired samples would need to be collected in order to detect a 25-percent difference between paired data sets (fig. 17). From figure 17, it becomes clear that smaller COVs require fewer samples to detect statistically relevant differences.

The ability to detect changes in sediment load at the basin outlet as a result of street sweeping relies on a direct relation between the amount of street-dirt available for washoff during a runoff event and the concentration and (or) load of sediment transported in runoff. The street sweepers tested during this study were able to significantly reduce the amount of street dirt. Therefore, a reduction in the amount of sediment transported into the stormwaterconveyance system should also have been measured. However, if a relation between street-dirt yield and sediment load in runoff did not exist, then it would be difficult to estimate the benefits of street sweeping on stormwater quality. A stepwise multivariate linear regression analysis incorporating precipitation depth, precipitation intensity, measured street-dirt yield prior to a runoff event, and suspended-sediment load was done to test whether a relation existed between street-dirt yield and suspended-sediment load. Results of the test indicated that street-dirt yields prior to a runoff event were unable to explain the variation in suspended-sediment loads at the 10-percent significance level. Owing to the lack of a significant relation between street-dirt yield and suspended-sediment load in stormwater runoff and the presence of large variation in measured data sets, determining the benefit of street sweepers as a stormwater-quality management tool becomes increasingly difficult.

\section{Potential Sources of Variability}

The control and test basins used in this study were selected to be close to together in order to minimize rainfall variability between basins. There are, however, other potential sources of variability in stormwater-quality loads within each basin that are difficult or impossible to measure. When using a paired-basin study design, it is assumed that the physical characteristics of each basin do not change other than the imposed treatment to the test basin. In a residential setting, anthropogenic sources such as home construction, lawn maintenance, or driving habits may introduce bias to constituent concentrations and loads. For example, residents in one study basin tended to keep brush and other vegetative debris piles on the terrace until maintenance crews could remove them for disposal. In another study basin, the same type of organic debris was

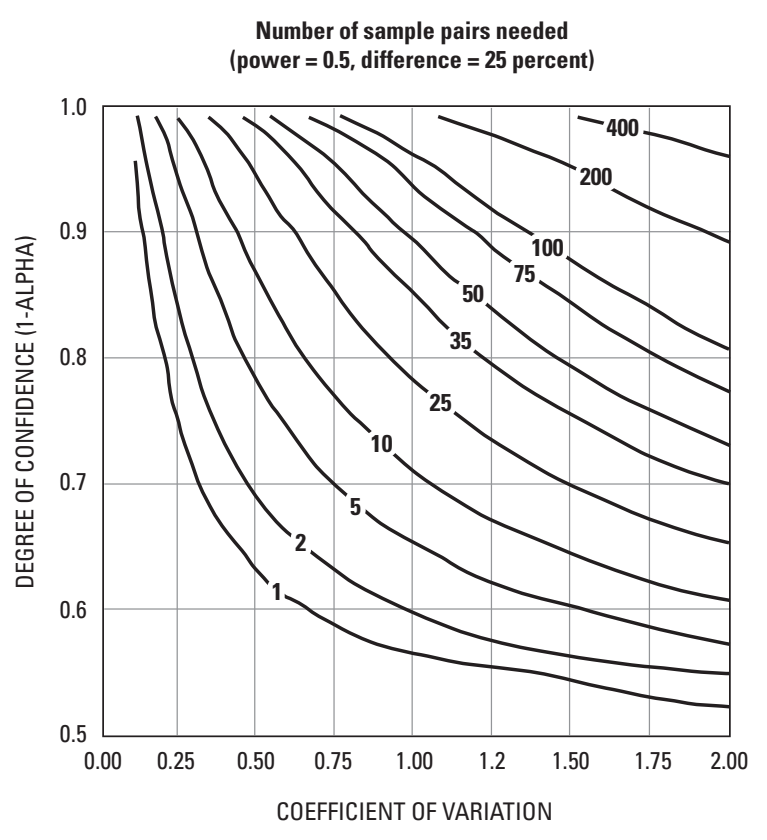

Figure 17. Estimated number of samples required to result in statistically relevant conclusions in a paired-basin study. (From Burton and Pitt, 2002, reproduced with permission.)

typically moved into the street gutter (fig. 18). Placement of debris in the gutter may not only act as a new source of phosphorus and nitrogen but also slow stormwater conveyed in the gutter during a runoff event, allowing sediment entrained in the runoff to settle. These brush piles were collected monthly and were avoided by street sweepers to prevent fouling of the mechanical equipment. Another human source of variability in constituent loads could have come from uneven distribution of sand during winter months for skid control (fig. 19). Applying more sand to the street surfaces in one study basin than another may have influenced sediment loads.

Other processes that may introduce variability are more mechanical. Despite the absence of catch basins in each basin's storm-sewer network, little is understood about the transport of sediment once it reaches the pipe. Sediment may accumulate and scour from one event to the next in various reaches of the storm sewer such that what is measured at the basin outlet may or may not have originated from the land surface. Figure 20 illustrates sediment that has accumulated in the irregularities of a manhole junction in the storm-sewer conveyance system. Similarly, during periods of heavy or intense rainfall, areas other than streets - such as lawns and roofs - may contribute to the sediment load measured near the basin outlet (fig. 21). Contributions of sediment from sources other than streets 


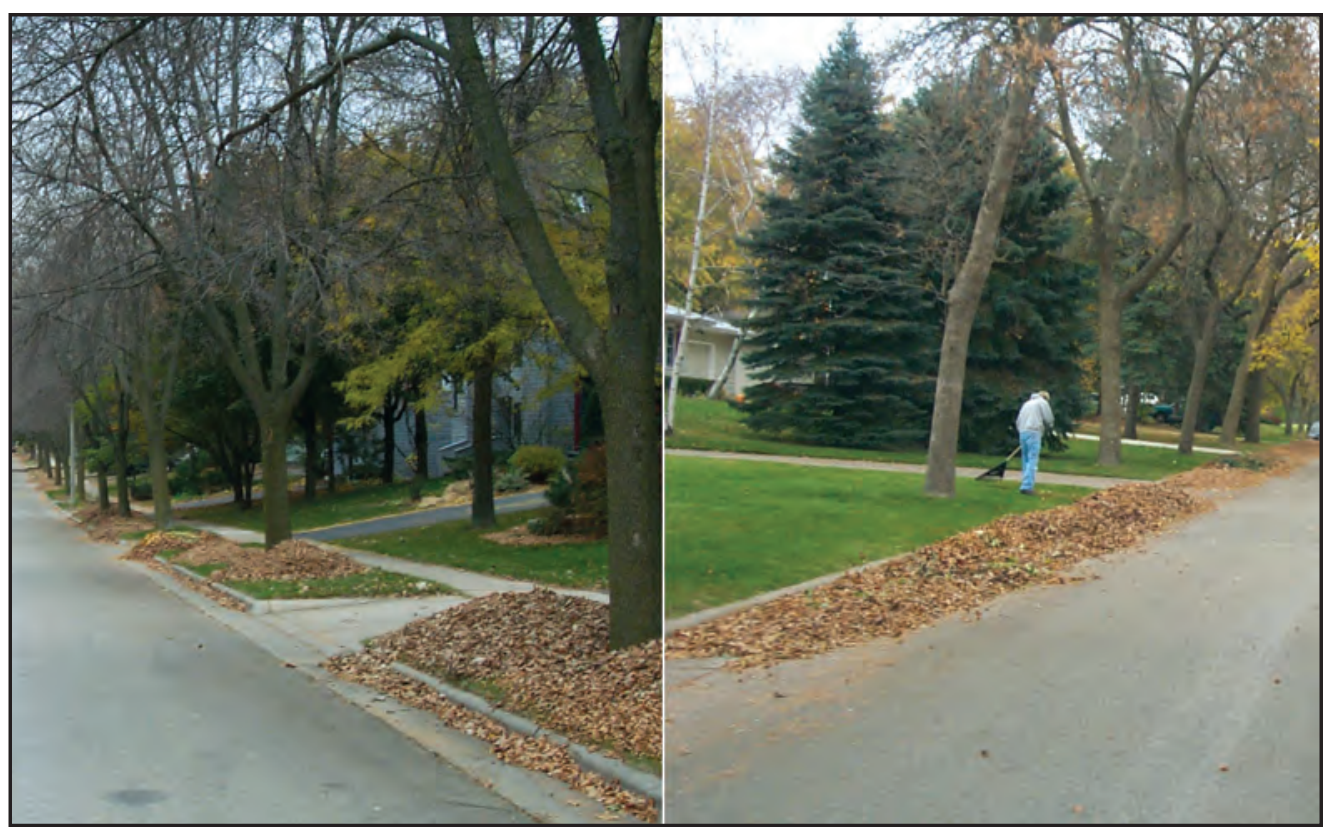

Figure 18. Examples of lawn-maintenance practices in two study basins. The pile of debris moved into the street may introduce sources of variability in measured water-quality loads.

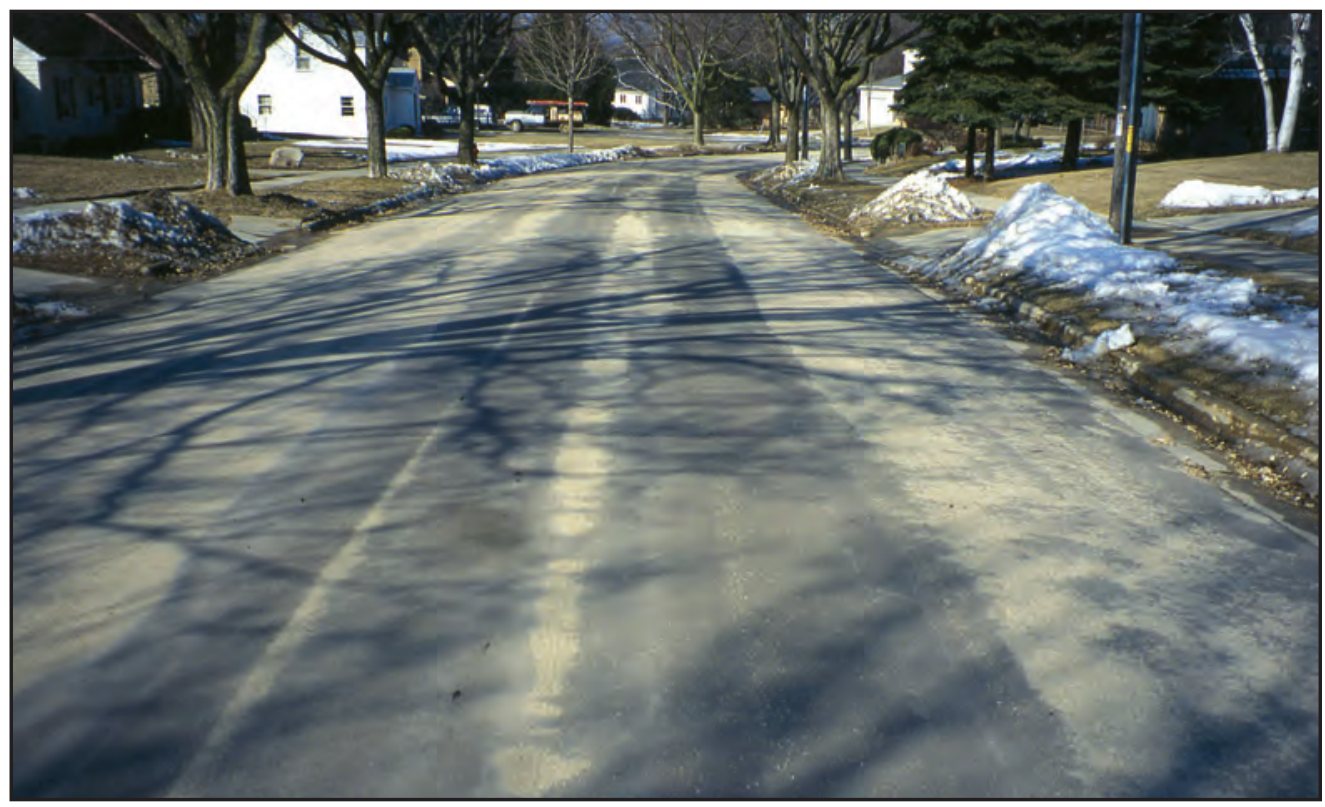

Figure 19. Residue from sand applied to a street surface to provide traction for vehicles. 


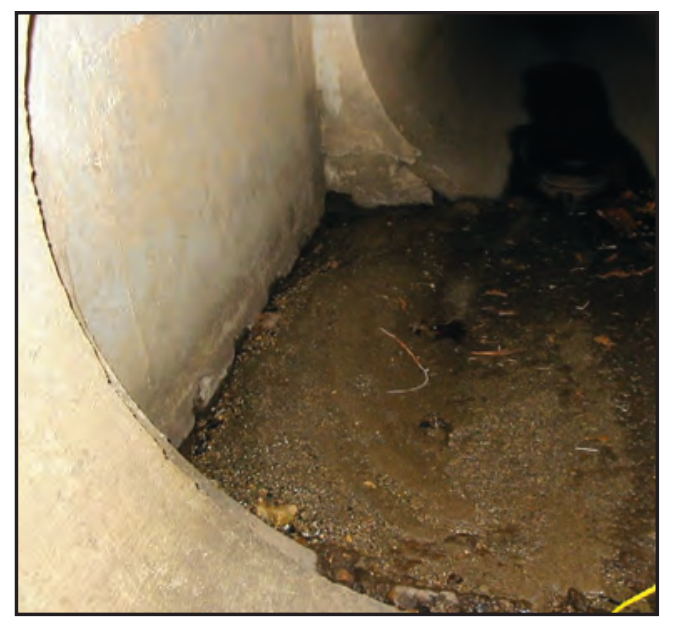

Figure 20. Accumulation of sediment in the junction of a manhole with the storm-sewer conveyance system.

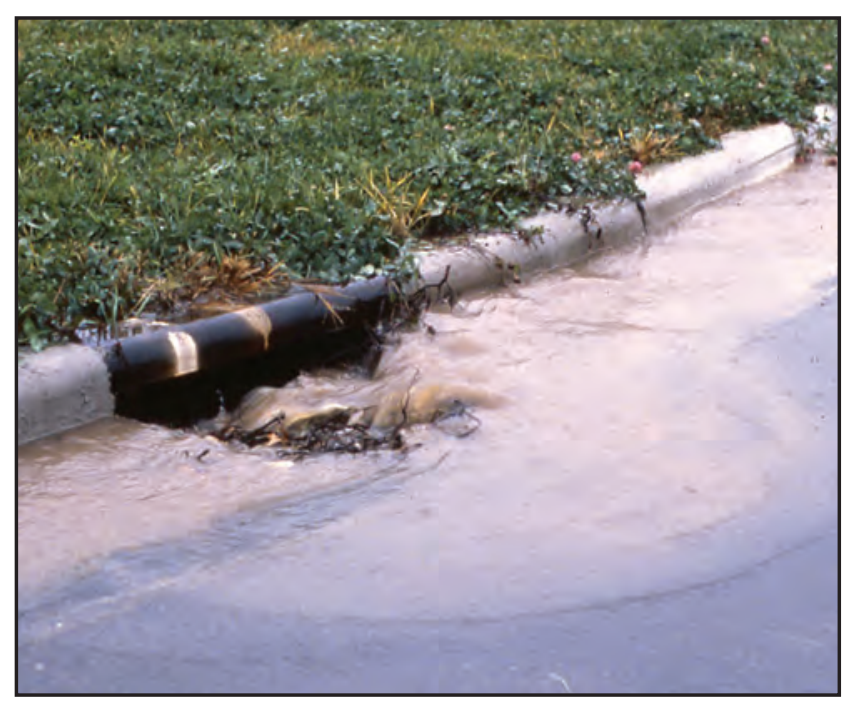

Figure 21. Contribution of sediment to a street from a residential lawn. could have potentially masked any effect street sweepers may have had on reducing the amount of sediment from street surfaces.

Once sediment from the land surface reaches the stormwater-conveyance system, it is assumed that particles of all sizes are well mixed throughout the water column before reaching the point at which a stormwater-quality sample is drawn. Typically, particles less than about 40 micrometers are well mixed within the water-column profile (Butler and others, 1996); however, as the particle- size distribution increases to include sand-size material (larger than 63 micrometers), a vertical gradient may form, with the largest particles concentrating near the bed (Bent and others, 2000). Evidence of changing suspended-sediment concentrations was reported by Smith (2002) when evaluating a small highway drainage pipe. Even at relatively low flows, concentrations of suspended sediment measured near the bottom of the pipe were approximately double those measured only a few inches higher (Smith, 2002). Because stormwater-quality samples used to evaluate the performance of street sweeping were acquired from a fixed point in the storm sewer, constituent concentrations may not have been representative of the water column during periods of high flows (fig. 22). This factor could have been another source of variability in concentrations and loads between the control and test basins.

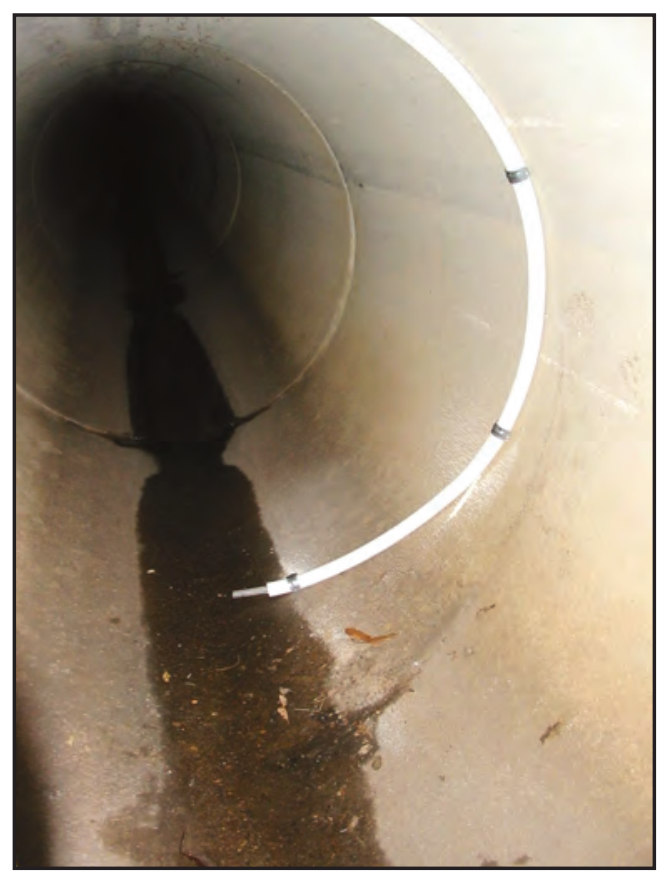

Figure 22. Water-quality sample intake located at a fixed point along the storm-sewer wall. 


\section{Comparison of Particle-Size Distribution in Stormwater-Quality Samples}

Table 15 summarizes the average distribution of particles for stormwater-quality samples collected in the control and test basins during the calibration and treatment phases of the study. During periods of no sweeping, both the air-sweeper and high-frequency broom test basins showed a similar distribution of particle sizes in runoff. Most particles for these two basins were greater than 250 micrometers. This is consistent with the average distribution of particles measured on street surfaces within each basin (table 9). This same pattern is also true during the treatment phase in the high-frequency broom basin. However, the air-sweeper basin shows an increase in the percentage of particles less than 63 micrometers; therefore, street sweeping resulted in a shift toward smaller particles sizes (table 15). Examination of the percentage of sand and silt reveals an overall increase in particles of silt size for both the air-sweeper and high-frequency broom basins during the treatment phase (table 15). This shift toward silt-sized particles may be related to sweeping. Although only a small percentage of street dirt was of silt size, a much larger percentage of these particles were measured in runoff at the basin outlet. On average, 3 to 5 percent of street dirt measured on the street surface was less than 63 micrometers (table 9), yet as much as 40 percent was found in the stormwater-quality samples. One explanation may be changes to sediment-transport functions as a result of sweeping. By removing larger particles from a street surface, the smaller particles may have become more easily entrained in runoff during rainstorms.

Table 15. Average percent distribution, by mass, of particle sizes for water-quality samples collected in the control and test basins during calibration and treatment phases.

[ $\mu \mathrm{m}$, micrometer; all values expressed as percent less than corresponding particle size]

\begin{tabular}{|c|c|c|c|c|c|}
\hline \multirow[b]{2}{*}{ Particle size } & \multicolumn{2}{|c|}{ Air sweeper basin } & \multicolumn{2}{|c|}{$\begin{array}{l}\text { High-frequency } \\
\text { broom basin }\end{array}$} & \multirow[b]{2}{*}{ Control } \\
\hline & Calibration & Treatment & Calibration & Treatment & \\
\hline $500 \mu \mathrm{m}$ & 66 & 85 & 68 & 88 & 76 \\
\hline $250 \mu \mathrm{m}$ & 43 & 54 & 46 & 49 & 53 \\
\hline $125 \mu \mathrm{m}$ & 31 & 40 & 30 & 33 & 39 \\
\hline $63 \mu \mathrm{m}$ & 24 & 34 & 22 & 28 & 29 \\
\hline $32 \mu \mathrm{m}$ & 13 & 19 & 12 & 21 & 17 \\
\hline $14 \mu \mathrm{m}$ & 9 & 14 & 8 & 16 & 13 \\
\hline $8 \mu \mathrm{m}$ & 7 & 12 & 7 & 12 & 10 \\
\hline $5 \mu \mathrm{m}$ & 5 & 10 & 5 & 9 & 8 \\
\hline $2 \mu \mathrm{m}$ & 3 & 6 & 2 & 2 & 4 \\
\hline Percent sand ${ }^{1}$ & 76 & 60 & 78 & 72 & 65 \\
\hline Percent silt ${ }^{1}$ & 24 & 40 & 22 & 28 & 35 \\
\hline
\end{tabular}

${ }^{1}$ Data sets used to determine the percentage of sand and silt were larger than those describing the full distribution. 


\section{Summary and Conclusions}

As part of fulfillment of the Environmental Protection Agency National Pollution Discharge Elimination System (NPDES) Phase II permit, many cities nationwide will be required to reduce the amount of sediment entrained in runoff from entering receiving water bodies. Many structural controls, such as detention ponds, are available to help environmental managers meet the NPDES permit requirements. However, these practices typically require large tracts of land that may be expensive or simply unavailable in an urban setting. Street sweeping is a nonstructural control that could be used to remove sediment and sediment-associated constituents from street surfaces before they become entrained in runoff. Because most cities already have some sort of street-sweeping program, it is important to understand the stormwater-quality benefits of existing or modified programs. More information is especially needed about the street-dirt removal capabilities of newer street-sweeper technologies.

To this end, the U.S. Geological Survey, in cooperation with the City of Madison and the Wisconsin Department of Natural Resources evaluated the performance of three street-sweeper technologies from 2002 through 2006. Specifically, this study examined the street-dirt-removal efficiencies and subsequent changes in stormwater-quality loads from basins where regenerative-air, vacuum-assisted, and mechanical-broom street sweepers operated on a frequency of once per week (high frequency). An additional mechanical-broom sweeper operating on a frequency of approximately once per month (low frequency) was also evaluated for street-dirt removal only. A paired-basin study design was used to compare street-dirt and stormwaterquality samples during a calibration period (no sweeping) and a treatment period (weekly sweeping). The basis of this paired-basin approach is that the relation between paired street-dirt yields and stormwater-quality loads for the control and test basins is constant until a major change is made at one of the basins. At that time, a new relation will develop.

Results show there is little probability that street sweeping, regardless of street-sweeper type, had any measurable affect on the quality of runoff. Street sweeping as a stormwater-quality-management tool appears to be limited by the extreme variability in stormwaterquality loads. It might be difficult to isolate any changes in stormwater quality as a result of street sweeping because other factors might be affecting the movement and supply of constituents in the watershed. Examples of factors that might contribute to the high variability include the amount of sediment delivered from other source areas such as lawns and driveways, the efficiency of sediment delivery in the storm-sewer system, and the changes in the amount of sand applied to enhance vehicle traction each winter. With high variability in stormwater-quality loads, a much larger number of water samples would have to be collected in order to detect any significant change due to street sweeping. For example, an estimated 200 paired stormwater-quality samples would have been required to detect a 25-percent change between the calibration and treatment periods. Only about 40 paired stormwater-quality samples were collected during this study.

Although a significant change was not observed for most of the constituents, a significant change (at the 10-percent significance level) was detected for ammonianitrogen for the vacuum-assist sweeper in the air-sweeper basin. When the vacuum-assist sweeper was used, an increase in ammonia-nitrogen load of 63 percent was measured.

Variability in street-dirt yields was not as great as that for stormwater-quality loads. The ability to physically reduce the amount of dirt present on a street surface, described in this study as sweeper efficiency, was measured by comparing street-dirt yields after a sweeper cleaned the streets in a basin to those measured before sweeper cleaning. Both the regenerative-air and vacuumassist sweepers averaged removal efficiencies of 25 and 30 percent, respectively. The mechanical-broom sweeper, operated on a weekly schedule, removed only 5 percent of street-dirt yield on average. Each sweeper showed increasing pickup efficiency with increasing street-dirt yield. The majority of street-dirt yield was measured during April and May of each study year. So in the spring, when the streetdirt yield was the highest, the street sweepers were somewhat more efficient. Street dirt during spring also appeared to be more uniformly distributed across the street surface than during the rest of the year. This is most likely due to residue from winter sand application. During the summer, 75 percent of the street-dirt yield is within 3 feet of the curb face. Therefore, street sweeping in spring might be more effective if the entire street is cleaned and not just the areas near the curb.

Differences in sweeper-removal efficiencies could be attributed to the advancements in technology incorporated into each sweeper. Combining a mechanical wire-bristle gutter broom with either a blast of air or vacuum suction appears to increase the ability of street sweepers to pick up available street dirt. This increase in street-dirt pickup efficiency was further demonstrated by comparing the 
overall reduction in street-dirt yield measured during the calibration and treatment periods. An analysis of covariance (ANCOVA) was used to quantify the average percent reduction of street dirt between study phases at the 5-percent significance level. Use of the regenerative-air and vacuum-assist sweepers resulted in the greatest reductions in average basin street-dirt yield of 76 and 63 percent, respectively. Use of the mechanical broom sweeper at high frequency resulted in a 20 -percent reduction in average basin street-dirt yield.

Such large changes in basin street-dirt yield are not consistent with the pickup efficiencies observed at the street level for each machine. The relatively large change in basin street-dirt yield may be explained by the mechanical action of the gutter broom increasing the amount of fines available for washoff. Increasing the amount of fines on a street can change the washoff characteristics of a street, because rain can be more effective at removing smaller particles from a street than street sweeping. If the amount of solids washed off the street is increased by the action of the street sweepers, the reduction in basin streetdirt yield could be a function of both the street sweepers' pickup efficiency and the increased effect of rainfall. The effect of rainfall is not considered when determining a sweeper's pickup efficiency. Furthermore, changes in washoff characteristics of street dirt could also have added to the difficulty in detecting any stormwater-quality benefits of street sweeping. One possible reason for this may be the mechanical action of the gutter brooms increasing the amount of fine particles on the street due to abrasion and the breakdown of larger particles. Because rain can more effectively remove small particles from the street rather than large particles, the amount of solids washed off the street may increase, negating any stormwater-quality benefits from street sweeping.

\section{Acknowledgments}

The authors thank Eric Booth, Justin Haasch, and Laura Wagner of the U.S. Geological Survey for their tireless efforts in the field. Collectively, they sampled more than 25 miles of street surface, characterized nearly 2 tons of street dirt, and processed more than 300 stormwaterquality samples.

\section{References}

American Public Health Association and others, 1989, Standard methods for the examination of water and wastewater (17th ed.): Washington D.C. [variously paginated].

Amy, G., Pitt, R., Singh, R., Bradford, W.L., and LaGraff, M.B., 1974, Stormwater quality management planning for urban runoff: Washington D.C., U.S. Environmental Protection Agency, EPA 440/9-75-004 [variously paginated].

Athayde, D.N., Shelly, P.E., Driscoll, E.D., Gaboury, D., and Boyd, G., 1983, Results of the Nationwide Urban Runoff Program-Volume 1, Final report: U.S. Environmental Protection Agency, WH-554, 186 p.

Bannerman, R., Baun, K., Bohn, M., Hughes, P.E., and Graczyk, D.A., 1983, Evaluation of urban nonpoint sources pollution management in Milwaukee County, Wisconsin-Volume I, Urban stormwater characteristics, constituent sources, and management by street sweeping: Chicago, U.S. Environmental Protection Agency [variously paginated]. [Available from National Technical Information Service, Springfield, VA 22161 (http://www.ntis.gov), item PB 84-114164.]

Bannerman, R.T, 1999, Sweeping water clean: American Sweeper Magazine, v. 7, no. 1, 4 p.

Bender, G.M., and Terstriep, M.L., 1984, Effectiveness of street sweeping in urban runoff pollution control: Science of the Total Environment, v. 33, p. 185-192.

Bent, G.C., Gray, J.R., Smith, K.P., and Glysson, G.D., 2000, A synopsis of technical issues for monitoring sediment in highway and urban runoff: U.S. Geological Survey Open-File Report 00-497, 51 p.

Breault, R.F., Smith, K.P., and Sorenson, J.R., 2005, Residential street-dirt accumulation rates and chemical composition, and removal efficiencies by mechanical- and vacuum-type sweepers, New Bedford, Massachusetts, 2003-04: U.S. Geological Survey Scientific Investigations Report 2005-5184, 27 p.

Burton, G.A., Jr., and Pitt. R.E., 2002, Stormwater effects handbook-A toolbox for watershed managers, scientists, and engineers: Boca Raton, Fla., Lewis Publishers, $929 \mathrm{p}$.

Butler, D., May, R.W.O., and Ackers, J.C., 1996, Sediment transport in sewers, Part I-Background: Proceedings of the Institution of Civil Engineers, Water Maritime and Energy, v. 118, no. 2, p. 103-112. 
Capel, P.D., and Larson, S.J., 1996, Evaluation of selected information on splitting devices for water samples: U.S. Geological Survey Water-Resources Investigations Report 95-4141, 103 p.

Clausen, J.C., and Spooner, J., 1993, Paired basin watershed study design: U.S. Environmental Protection Agency, Office of Water, EPA-841-F-93-009, 8 p.

German, J, and Svensson, G. 2002, Metal content and particle size distribution of street sediments and street sweeping waste: Water Science and Technology, v. 46, nos. 6-7, p. 191-198.

Gray, J.R., Glysson, G.D., Torcios, L.M., and Schwartz, G., 2000, Comparability of suspended-sediment concentration and total suspended solids data: U.S. Geological Survey Water-Resources Investigation Report 00-4191, $14 \mathrm{p}$.

Guy, H.P., 1969, Laboratory theory and methods for sediment analysis: U.S. Geological Survey Techniques of Water-Resources Investigations, book 5, chap. C1, 58 p.

Hansen, J., Sesing, M., Hughes, P., and Graczyk, D. 1984, Evaluation of Urban Nonpoint Source Pollution Management in Milwaukee County, Wisconsin-Vol IIIStudy Site Characteristics, Experimental Methods and Quality Assurance Program: Wisconsin Department of Natural Resources, PB 84-114180 [variously paginated].

Helsel, D.R., and Hirsch, R.M., 1992, Statistical methods in water resources: New York, Elsevier, 522 p.

Horowitz, A. J., 1985, A primer on trace metal-sediment chemistry: U.S. Geological Survey Water-Supply Paper 2277, 67 p.

Horowitz, A.J., Hayes, T.S., Gray, J.R., and Capel, P.D., 1997, Selected laboratory tests of the whole-stormwater sample splitting capabilities of the 14-liter churn and the Teflon cone splitters: U.S. Geological Survey Office of Stormwater quality Technical Memorandum 97.06.

Horwatich, J.A., Corsi, S.R., and Bannerman, R.T., 2004, Effectiveness of a pressurized stormwater filtration system in Green Bay, Wisconsin-A study for the Environmental Technology Verification Program of the U.S. Environmental Protection Agency: U.S. Geological Survey Scientific Investigations Report 2004-5222, 19 p.

National Climatic Data Center, 2003, Local climatological data-Madison, Wisconsin-annual summary with comparative data: ISSN 0198-5728, 8 p.

Pitt, R., 1979, Demonstration of nonpoint pollution abatement through improved street cleaning practices: Washington D.C., U.S. Environmental Protection Agency, EPA-600/2-79/161, 269 p.
Pitt, R., 1985, Characterizing and controlling urban runoff through street and sewerage cleaning: Cincinnati, Ohio, U.S. Environmental Protection Agency, Storm and Combined Sewer Program, Risk Reduction Engineering Laboratory, EPA/600/S2-85/038, 8 p. [Available from National Technical Information Service, Springfield, VA 22161 (http://www.ntis.gov), item PB 85-186500.]

Pitt, R., and Amy, G., 1973, Toxic materials analysis of street surface constituents: Washington D.C., U.S. Environmental Protection Agency, EPA-R2-73-283, 143 p. [Available from National Technical Information Service, Springfield, VA 22161 (http://www.ntis.gov), item PB 224-677.]

Pitt, R., Bannerman, R., and Sutherland, R., 2004, The role of street cleaning in stormwater management, in American Society of Civil Engineers, World Water and Environment Congress, Salt Lake City, June 28-July 1, 2004, Proceedings: 9 p.

Prych, E.A., and Ebbert, J.C., 1986, Quantity and quality of storm runoff from three urban catchments in Bellevue, Washington: U.S. Geological Survey WaterResources Investigations Report 86-4000, 85 p.

Sansalone, J., Koran, J., Smithson, J., and Buchberger, S., 1998, Physical characteristics of urban roadway solids transported during rain events: Journal of Environmental Engineering, v. 4, no. 5, p. 427-440.

Sartor, J.D., and Boyd, G.B., 1972, Water pollution aspects of street surface constituents: Washington D.C., U.S. Environmental Protection Agency, EPA-R2-72-081, p. 458-467.

Selbig, W.R., Bannerman, Roger, and Bowman, George, 2007, Improving the accuracy of sediment-associated constituent concentrations in whole stormwater samples by wet-sieving: Journal of Environmental Quality, v. 36, no. $1,7 \mathrm{p}$.

Shoemaker, L., Lahlou, M., Doll, A., and Cazenas, P., 2000, Stormwater best management practices in an ultra-urban setting — Selection and monitoring: Federal Highway Administration, FHWA-EP-00-002, 287 p.

Smith, K.P., 2002, Effectiveness of three best management practices for highway-runoff quality along the southeast expressway, Boston, Massachusetts: U.S. Geological Survey Water-Resources Investigations Report 02-4059, $62 \mathrm{p}$.

Steuer, Jeffrey; Selbig, William; Hornewer, Nancy; and Prey, Jeffrey, 1997, Sources of contamination in an urban basin in Marquette, Michigan, and an analysis of concentrations, loads, and data quality: U.S. Geological Survey Water-Resources Investigations Report 97-4242, $25 \mathrm{p}$. 
Sutherland, R.C., and Jelen, S.L., 1997, Contrary to conventional wisdom, street sweeping can be an effective BMP, in James, W., ed., Advances in modeling the management of stormwater impacts: Guelph, Ontario, Computational Hydraulics International, v. 5., p. 179-190.

Terrene Institute, 1998, A clean sweep now possible: Virginia, Runoff Report, The Terrene Institute, v. 6, no. 4, $4 \mathrm{p}$.

U.S. Environmental Protection Agency, 1979, Methods for chemical analysis of water and wastes: EPA 600/4-79020, $460 \mathrm{p}$.

U.S. Environmental Protection Agency, 1982, Results of the Nationwide Urban Runoff Program-Volume II, Appendices: U.S. Environmental Protection Agency [variously paginated]. [Available from National Technical Information Service, Springfield, VA 22161 (http:// www.ntis.gov), item PB84-185560.]

U.S. Environmental Protection Agency, 1983, Nationwide Urban Runoff Program, Winston-Salem, N.C.-An evaluation of street sweeping as a runoff pollution control: Office of Water Programs, 229 p. [Available from National Technical Information Service, Springfield, VA 22161 (http://www.ntis.gov), item PB85-102507.]

Waschbusch, R.J., Selbig, W.R., and Bannerman, R.T., 1999, Sources of phosphorus in stormwater and streetdirt from two urban residential basins in Madison, Wisconsin, 1994-95: U.S. Geological Survey WaterResources Investigations Report 99-4021, 47 p.

Wheaton, S.R., Brown, C., and Gropp, E., 1999, Street sediment buildup rates in Anchorage, Alaska, in Proceedings of the fifth international symposium on cold region development, May 1997: American Society of Civil Engineers, p. 545-548.

Wisconsin Administrative Code, 2002, Wisconsin Department of Natural Resources-Runoff management: Chap. NR 151 [variously paginated].

Zarriello, P.J., Breault, R.F., and Weiskel, P.K., 2002, Potential effects of structural controls and street sweeping on stormwater loads to the Lower Charles River, Massachusetts: U.S. Geological Survey Water-Resources Investigations Report 02-4220, 42 p. 


\section{Appendixes}


Appendix 1. Detailed street-dirt and water-quality data

Appendix table 1-1. Control basin street-dirt yield, in pounds per curb-mile, separated by particle size.

[mm/dd/yyyy, month/day/year; $\mu \mathrm{m}$, micrometer; >, greater than; <, less than]

\begin{tabular}{|c|c|c|c|c|c|c|c|c|}
\hline \multirow{2}{*}{$\begin{array}{c}\text { Date } \\
\text { (mm/dd/yyyy) }\end{array}$} & \multicolumn{8}{|c|}{$\begin{array}{l}\text { Street-dirt yield } \\
\text { (pounds per curb-mile) }\end{array}$} \\
\hline & $>2,000 \mu \mathrm{m}$ & $1,000-2,000 \mu \mathrm{m}$ & $500-1,000 \mu \mathrm{m}$ & $250-500 \mu \mathrm{m}$ & $125-250 \mu \mathrm{m}$ & $63-125 \mu \mathrm{m}$ & $<63 \mu \mathrm{m}$ & Total \\
\hline $05 / 17 / 2002$ & 87 & 125 & 177 & 221 & 86 & 34 & 25 & 755 \\
\hline $05 / 24 / 2002$ & 81 & 118 & 176 & 207 & 95 & 38 & 33 & 748 \\
\hline $05 / 31 / 2002$ & 91 & 111 & 174 & 212 & 77 & 20 & 11 & 695 \\
\hline 06/07/2002 & 69 & 93 & 118 & 132 & 46 & 12 & 9 & 479 \\
\hline $06 / 14 / 2002$ & 52 & 69 & 90 & 111 & 45 & 12 & 5 & 385 \\
\hline $06 / 20 / 2002$ & 70 & 94 & 124 & 158 & 70 & 23 & 11 & 549 \\
\hline $06 / 28 / 2002$ & 52 & 66 & 108 & 152 & 71 & 24 & 16 & 489 \\
\hline 07/05/2002 & 88 & 96 & 151 & 202 & 95 & 30 & 48 & 710 \\
\hline $07 / 12 / 2002$ & 102 & 131 & 202 & 266 & 135 & 57 & 57 & 950 \\
\hline $07 / 19 / 2002$ & 70 & 101 & 163 & 229 & 145 & 68 & 100 & 876 \\
\hline 07/26/2002 & 77 & 89 & 123 & 149 & 79 & 32 & 33 & 582 \\
\hline $08 / 02 / 2002$ & 78 & 86 & 120 & 155 & 77 & 29 & 27 & 571 \\
\hline 08/09/2002 & 55 & 69 & 96 & 128 & 67 & 25 & 19 & 458 \\
\hline $08 / 16 / 2002$ & 64 & 69 & 101 & 134 & 70 & 24 & 19 & 482 \\
\hline 08/30/2002 & 58 & 64 & 93 & 126 & 71 & 29 & 27 & 467 \\
\hline 09/06/2002 & 80 & 103 & 139 & 180 & 107 & 51 & 58 & 717 \\
\hline $09 / 13 / 2002$ & 61 & 91 & 130 & 151 & 76 & 32 & 26 & 567 \\
\hline $09 / 27 / 2002$ & 95 & 120 & 172 & 239 & 141 & 65 & 71 & 902 \\
\hline 04/01/2003 & 206 & 319 & 580 & 861 & 354 & 102 & 70 & 2,493 \\
\hline $04 / 15 / 2003$ & 199 & 281 & 495 & 705 & 341 & 126 & 135 & 2,282 \\
\hline $04 / 23 / 2003$ & 181 & 269 & 428 & 606 & 285 & 94 & 88 & 1,951 \\
\hline $04 / 29 / 2003$ & 142 & 223 & 373 & 542 & 329 & 130 & 139 & 1,878 \\
\hline 05/06/2003 & 154 & 242 & 340 & 314 & 258 & 49 & 23 & 1,380 \\
\hline $05 / 13 / 2003$ & 172 & 234 & 321 & 409 & 189 & 64 & 42 & 1,431 \\
\hline 05/20/2003 & 78 & 121 & 165 & 172 & 84 & 34 & 12 & 667 \\
\hline $05 / 27 / 2003$ & 100 & 161 & 229 & 289 & 192 & 90 & 78 & 1,139 \\
\hline 06/03/2003 & 57 & 111 & 171 & 259 & 149 & 49 & 36 & 832 \\
\hline $06 / 11 / 2003$ & 68 & 116 & 183 & 267 & 152 & 59 & 34 & 878 \\
\hline 06/17/2003 & 57 & 117 & 176 & 250 & 156 & 68 & 51 & 875 \\
\hline $06 / 26 / 2003$ & 54 & 92 & 116 & 140 & 73 & 21 & 8 & 503 \\
\hline $07 / 01 / 2003$ & 74 & 113 & 168 & 251 & 159 & 76 & 61 & 901 \\
\hline $07 / 11 / 2003$ & 41 & 78 & 112 & 147 & 105 & 27 & 12 & 522 \\
\hline $07 / 23 / 2003$ & 74 & 81 & 101 & 150 & 102 & 44 & 32 & 585 \\
\hline 07/30/2003 & 67 & 93 & 148 & 221 & 140 & 62 & 49 & 781 \\
\hline $08 / 05 / 2003$ & 35 & 57 & 88 & 144 & 89 & 32 & 22 & 467 \\
\hline $08 / 12 / 2003$ & 51 & 62 & 99 & 208 & 111 & 49 & 52 & 632 \\
\hline 08/20/2003 & 92 & 96 & 158 & 294 & 187 & 72 & 50 & 949 \\
\hline 08/27/2003 & 116 & 108 & 127 & 212 & 145 & 51 & 26 & 785 \\
\hline
\end{tabular}


Appendix 1. Detailed street-dirt and water-quality data-Continued.

Appendix table 1-1. Control basin street-dirt yield, in pounds per curb-mile, separated by particle size—Continued. [mm/dd/yyyy, month/day/year; $\mu \mathrm{m}$, micrometer; >, greater than; <, less than]

\begin{tabular}{|c|c|c|c|c|c|c|c|c|}
\hline \multirow{2}{*}{$\begin{array}{c}\text { Date } \\
\text { (mm/dd/yyyy) }\end{array}$} & \multicolumn{8}{|c|}{$\begin{array}{c}\text { Street-dirt yield } \\
\text { (pounds per curb-mile) }\end{array}$} \\
\hline & $>2,000 \mu \mathrm{m}$ & $1,000-2,000 \mu \mathrm{m}$ & $500-1,000 \mu \mathrm{m}$ & $250-500 \mu \mathrm{m}$ & $125-250 \mu \mathrm{m}$ & $63-125 \mu \mathrm{m}$ & $<63 \mu \mathrm{m}$ & Total \\
\hline 09/02/2003 & 100 & 97 & 119 & 185 & 127 & 46 & 33 & 706 \\
\hline 09/09/2003 & 76 & 99 & 133 & 213 & 149 & 61 & 50 & 782 \\
\hline 09/16/2003 & 76 & 85 & 109 & 145 & 86 & 29 & 20 & 549 \\
\hline 09/23/2003 & 88 & 92 & 109 & 154 & 85 & 28 & 14 & 571 \\
\hline 09/30/2003 & 92 & 81 & 100 & 153 & 96 & 39 & 26 & 588 \\
\hline 10/07/2003 & 113 & 131 & 218 & 285 & 240 & 56 & 40 & 1,082 \\
\hline 04/06/2004 & 75 & 98 & 219 & 386 & 158 & 47 & 22 & 1,004 \\
\hline 04/13/2004 & 61 & 95 & 221 & 452 & 217 & 91 & 73 & 1,211 \\
\hline $04 / 27 / 2004$ & 63 & 82 & 148 & 238 & 105 & 36 & 24 & 696 \\
\hline 05/04/2004 & 65 & 89 & 146 & 710 & 109 & 46 & 38 & 1,202 \\
\hline 05/19/2004 & 42 & 52 & 80 & 114 & 46 & 12 & 5 & 351 \\
\hline $05 / 26 / 2004$ & 43 & 46 & 68 & 122 & 66 & 20 & 15 & 382 \\
\hline 06/02/2004 & 41 & 48 & 62 & 100 & 59 & 19 & 13 & 341 \\
\hline 06/08/2004 & 48 & 56 & 85 & 144 & 82 & 34 & 25 & 473 \\
\hline $06 / 15 / 2004$ & 57 & 49 & 70 & 108 & 61 & 23 & 15 & 383 \\
\hline $06 / 22 / 2004$ & 32 & 45 & 82 & 125 & 48 & 17 & 7 & 356 \\
\hline 06/29/2004 & 57 & 62 & 108 & 190 & 104 & 36 & 26 & 583 \\
\hline 07/08/2004 & 38 & 34 & 48 & 81 & 50 & 17 & 12 & 279 \\
\hline 07/14/2004 & 35 & 39 & 59 & 108 & 71 & 28 & 16 & 358 \\
\hline 07/20/2004 & 34 & 41 & 64 & 97 & 49 & 18 & 10 & 313 \\
\hline 07/27/2004 & 40 & 47 & 76 & 132 & 82 & 36 & 36 & 450 \\
\hline 08/03/2004 & 39 & 46 & 82 & 127 & 53 & 17 & 12 & 375 \\
\hline 08/10/2004 & 41 & 51 & 86 & 153 & 81 & 29 & 24 & 465 \\
\hline 08/18/2004 & 66 & 65 & 91 & 132 & 73 & 33 & 23 & 482 \\
\hline 08/31/2004 & 38 & 42 & 49 & 66 & 40 & 17 & 8 & 261 \\
\hline 09/07/2004 & 56 & 59 & 71 & 107 & 74 & 36 & 29 & 431 \\
\hline 09/17/2004 & 55 & 55 & 59 & 74 & 38 & 16 & 9 & 307 \\
\hline 04/05/2005 & 65 & 84 & 255 & 671 & 317 & 127 & 85 & 1,603 \\
\hline $04 / 13 / 2005$ & 51 & 70 & 179 & 415 & 199 & 71 & 32 & 1,017 \\
\hline $04 / 21 / 2005$ & 62 & 75 & 175 & 405 & 206 & 80 & 44 & 1,047 \\
\hline $04 / 28 / 2005$ & 71 & 75 & 160 & 353 & 172 & 73 & 45 & 948 \\
\hline $05 / 05 / 2005$ & 67 & 95 & 186 & 401 & 197 & 89 & 45 & 1,080 \\
\hline $05 / 18 / 2005$ & 67 & 73 & 129 & 248 & 131 & 52 & 30 & 730 \\
\hline 05/25/2005 & 64 & 80 & 128 & 236 & 119 & 47 & 31 & 704 \\
\hline $06 / 02 / 2005$ & 81 & 110 & 165 & 305 & 168 & 79 & 57 & 964 \\
\hline
\end{tabular}


Appendix 1. Detailed street-dirt and water-quality data-Continued.

Appendix table 1-2. Air-sweeper basin street-dirt yield, in pounds per curb-mile, separated by particle size.

[mm/dd/yyyy, month/day/year; $\mu \mathrm{m}$, micrometer; >, greater than; <, less than; NS, no sweeping in basin; --, no data]

\begin{tabular}{|c|c|c|c|c|c|c|c|c|c|}
\hline \multirow{2}{*}{$\begin{array}{c}\text { Date } \\
\text { (mm/dd/yyyy) }\end{array}$} & \multirow{2}{*}{$\begin{array}{l}\text { Sweeper } \\
\text { cleaning }\end{array}$} & \multicolumn{8}{|c|}{$\begin{array}{c}\text { Street-dirt yield } \\
\text { (pounds per curb-mile) }\end{array}$} \\
\hline & & $>2,000 \mu \mathrm{m}$ & $1,000-2,000 \mu \mathrm{m}$ & $500-1,000 \mu \mathrm{m}$ & $250-500 \mu \mathrm{m}$ & $125-250 \mu \mathrm{m}$ & $63-125 \mu \mathrm{m}$ & $<63 \mu \mathrm{m}$ & Total \\
\hline $05 / 17 / 2002$ & NS & 123 & 205 & 333 & 508 & 197 & 53 & 26 & 1,445 \\
\hline $05 / 24 / 2002$ & NS & 113 & 206 & 354 & 521 & 225 & 71 & 43 & 1,531 \\
\hline $05 / 31 / 2002$ & NS & 108 & 156 & 248 & 347 & 144 & 35 & 15 & 1,053 \\
\hline 06/07/2002 & NS & 82 & 103 & 136 & 175 & 73 & 18 & 9 & 596 \\
\hline 06/20/2002 & NS & 66 & 99 & 141 & 208 & 106 & 32 & 17 & 668 \\
\hline $06 / 28 / 2002$ & NS & 75 & 101 & 177 & 326 & 148 & 40 & 21 & 888 \\
\hline $07 / 05 / 2002$ & NS & 78 & 95 & 174 & 310 & 151 & 40 & 26 & 874 \\
\hline $07 / 12 / 2002$ & NS & 72 & 107 & 187 & 361 & 183 & 58 & 32 & 1,000 \\
\hline 07/19/2002 & NS & 62 & 99 & 155 & 270 & 167 & 61 & 39 & 854 \\
\hline $07 / 26 / 2002$ & NS & 68 & 87 & 126 & 189 & 100 & 34 & 20 & 624 \\
\hline 08/02/2002 & NS & 86 & 117 & 196 & 317 & 146 & 43 & 23 & 928 \\
\hline 08/09/2002 & NS & 90 & 129 & 177 & 260 & 160 & 64 & 45 & 924 \\
\hline $08 / 16 / 2002$ & NS & 85 & 117 & 181 & 261 & 150 & 49 & 27 & 870 \\
\hline 08/30/2002 & NS & 93 & 117 & 180 & 335 & 177 & 49 & 32 & 985 \\
\hline 09/06/2002 & NS & 94 & 131 & 243 & 454 & 204 & 55 & 36 & 1,217 \\
\hline $09 / 13 / 2002$ & NS & 101 & 137 & 225 & 372 & 174 & 42 & 30 & 1,081 \\
\hline 09/27/2002 & NS & 85 & 109 & 144 & 183 & 104 & 33 & 18 & 676 \\
\hline $04 / 01 / 2003$ & Pre & 72 & 140 & 373 & 652 & 251 & 54 & 21 & 1,563 \\
\hline $04 / 02 / 2003$ & Post & 31 & 62 & 196 & 433 & 236 & 74 & 49 & 1,082 \\
\hline $04 / 15 / 2003$ & Pre & 44 & 79 & 216 & 430 & 234 & 76 & 56 & 1,134 \\
\hline $04 / 16 / 2003$ & Post & 30 & 60 & 162 & 315 & 202 & 69 & 56 & 894 \\
\hline $04 / 22 / 2003$ & Pre & 39 & 71 & 186 & 357 & 209 & 58 & 30 & 949 \\
\hline $04 / 23 / 2003$ & Post & 24 & 45 & 116 & 224 & 168 & 59 & 41 & 677 \\
\hline $04 / 29 / 2003$ & Pre & 26 & 47 & 123 & 249 & 190 & 65 & 76 & 777 \\
\hline $04 / 30 / 2003$ & Post & -- & -- & -- & -- & -- & -- & -- & -- \\
\hline $05 / 06 / 2003$ & Pre & 40 & 71 & 139 & 195 & 151 & 34 & 15 & 646 \\
\hline 05/07/2003 & Post & -- & -- & -- & -- & -- & -- & -- & -- \\
\hline $05 / 12 / 2003$ & Pre & 29 & 59 & 119 & 190 & 88 & 26 & 7 & 518 \\
\hline $05 / 13 / 2003$ & Post & 21 & 42 & 97 & 171 & 88 & 24 & 17 & 461 \\
\hline $05 / 20 / 2003$ & Pre & 26 & 41 & 75 & 109 & 49 & 13 & 7 & 320 \\
\hline $05 / 21 / 2003$ & Post & 13 & 29 & 56 & 99 & 62 & 23 & 14 & 298 \\
\hline $05 / 27 / 2003$ & Pre & 24 & 46 & 93 & 168 & 106 & 43 & 20 & 500 \\
\hline $05 / 28 / 2003$ & Post & -- & -- & -- & -- & -- & -- & -- & -- \\
\hline 06/03/2003 & Pre & 19 & 40 & 66 & 119 & 84 & 37 & 17 & 382 \\
\hline $06 / 04 / 2003$ & Post & 14 & 26 & 51 & 90 & 71 & 33 & 30 & 316 \\
\hline $06 / 11 / 2003$ & Pre & 16 & 30 & 49 & 78 & 53 & 23 & 11 & 259 \\
\hline $06 / 12 / 2003$ & Post & 11 & 18 & 31 & 52 & 34 & 15 & 9 & 169 \\
\hline
\end{tabular}


Appendix 1. Detailed street-dirt and water-quality data-Continued.

Appendix table 1-2. Air-sweeper basin street-dirt yield, in pounds per curb-mile, separated by particle size-Continued.

[mm/dd/yyyy, month/day/year; $\mu \mathrm{m}$, micrometer; >, greater than; <, less than; NS, no sweeping in basin; --, no data]

\begin{tabular}{|c|c|c|c|c|c|c|c|c|c|}
\hline \multirow{2}{*}{$\begin{array}{c}\text { Date } \\
\text { (mm/dd/yyyy) }\end{array}$} & \multirow{2}{*}{$\begin{array}{l}\text { Sweeper } \\
\text { cleaning }\end{array}$} & \multicolumn{8}{|c|}{$\begin{array}{c}\text { Street-dirt yield } \\
\text { (pounds per curb-mile) }\end{array}$} \\
\hline & & $>2,000 \mu \mathrm{m}$ & $1,000-2,000 \mu \mathrm{m}$ & $500-1,000 \mu \mathrm{m}$ & $250-500 \mu \mathrm{m}$ & $125-250 \mu \mathrm{m}$ & $63-125 \mu \mathrm{m}$ & $<63 \mu \mathrm{m}$ & Total \\
\hline $06 / 16 / 2003$ & Pre & 21 & 26 & 40 & 68 & 48 & 28 & 23 & 253 \\
\hline $06 / 17 / 2003$ & Post & 9 & 18 & 32 & 57 & 43 & 23 & 20 & 202 \\
\hline $06 / 26 / 2003$ & Pre & 15 & 22 & 25 & 32 & 17 & 6 & 2 & 119 \\
\hline $06 / 26 / 2003$ & Post & 16 & 26 & 28 & 48 & 34 & 15 & 9 & 177 \\
\hline 07/01/2003 & Pre & 14 & 25 & 31 & 38 & 52 & 16 & 8 & 183 \\
\hline $07 / 02 / 2003$ & Post & 10 & 16 & 26 & 47 & 35 & 17 & 11 & 162 \\
\hline $07 / 11 / 2003$ & Pre & 11 & 13 & 18 & 28 & 21 & 9 & 6 & 106 \\
\hline $07 / 16 / 2003$ & Pre & 18 & 18 & 25 & 40 & 28 & 11 & 6 & 146 \\
\hline $07 / 17 / 2003$ & Post & 9 & 12 & 17 & 30 & 24 & 11 & 5 & 108 \\
\hline $07 / 22 / 2003$ & Pre & 18 & 15 & 21 & 38 & 29 & 13 & 7 & 142 \\
\hline $07 / 23 / 2003$ & Post & 12 & 10 & 14 & 26 & 21 & 11 & 12 & 106 \\
\hline $07 / 29 / 2003$ & Pre & 15 & 19 & 26 & 45 & 38 & 21 & 21 & 185 \\
\hline $07 / 30 / 2003$ & Post & 10 & 12 & 18 & 33 & 29 & 16 & 14 & 132 \\
\hline $08 / 05 / 2003$ & Pre & 13 & 14 & 15 & 22 & 19 & 10 & 10 & 103 \\
\hline 08/06/2003 & Post & -- & -- & -- & -- & -- & -- & -- & -- \\
\hline $08 / 12 / 2003$ & Pre & 19 & 20 & 24 & 42 & 35 & 11 & 16 & 167 \\
\hline $08 / 13 / 2003$ & Post & 12 & 12 & 17 & 29 & 26 & 13 & 10 & 119 \\
\hline $08 / 19 / 2003$ & Pre & 17 & 18 & 22 & 38 & 35 & 19 & 19 & 169 \\
\hline $08 / 20 / 2003$ & Post & 11 & 13 & 15 & 25 & 22 & 12 & 11 & 110 \\
\hline $08 / 26 / 2003$ & Pre & 16 & 19 & 19 & 29 & 24 & 11 & 7 & 124 \\
\hline $08 / 27 / 2003$ & Post & 11 & 14 & 18 & 28 & 22 & 13 & 14 & 121 \\
\hline $09 / 02 / 2003$ & Pre & 15 & 16 & 16 & 24 & 21 & 12 & 11 & 115 \\
\hline 09/03/2003 & Post & 10 & 10 & 11 & 16 & 14 & 9 & 10 & 79 \\
\hline 09/09/2003 & Pre & 17 & 18 & 20 & 28 & 24 & 16 & 18 & 140 \\
\hline 09/10/2003 & Post & 9 & 11 & 12 & 17 & 14 & 9 & 11 & 82 \\
\hline $09 / 16 / 2003$ & Pre & 16 & 16 & 13 & 17 & 13 & 5 & 3 & 83 \\
\hline 09/17/2003 & Post & 10 & 9 & 9 & 12 & 12 & 6 & 6 & 64 \\
\hline $09 / 23 / 2003$ & Pre & 17 & 22 & 18 & 17 & 24 & 7 & 4 & 109 \\
\hline $09 / 24 / 2003$ & Post & 11 & 11 & 11 & 16 & 14 & 8 & 7 & 79 \\
\hline $09 / 30 / 2003$ & Pre & 23 & 25 & 22 & 27 & 22 & 12 & 9 & 140 \\
\hline $10 / 01 / 2003$ & Post & 13 & 14 & 12 & 18 & 16 & 11 & 10 & 95 \\
\hline $10 / 07 / 2003$ & Pre & 25 & 59 & 31 & 31 & 25 & 16 & 13 & 200 \\
\hline $10 / 08 / 2003$ & Post & 24 & 24 & 19 & 24 & 21 & 13 & 16 & 141 \\
\hline $04 / 06 / 2004$ & Pre & 65 & 88 & 249 & 490 & 175 & 50 & 20 & 1,137 \\
\hline $04 / 09 / 2004$ & Post & 36 & 65 & 203 & 486 & 220 & 95 & 73 & 1,178 \\
\hline $04 / 13 / 2004$ & Pre & 31 & 57 & 174 & 419 & 202 & 78 & 51 & 1,012 \\
\hline 04/16/2004 & Post & 11 & 18 & 53 & 136 & 68 & 26 & 14 & 326 \\
\hline
\end{tabular}


Appendix 1. Detailed street-dirt and water-quality data-Continued.

Appendix table 1-2. Air-sweeper basin street-dirt yield, in pounds per curb-mile, separated by particle size—Continued.

$[\mathrm{mm} / \mathrm{dd} / \mathrm{yyyy}$, month/day/year; $\mu \mathrm{m}$, micrometer; >, greater than; <, less than; NS, no sweeping in basin; --, no data]

\begin{tabular}{|c|c|c|c|c|c|c|c|c|c|}
\hline \multirow{2}{*}{$\begin{array}{c}\text { Date } \\
\text { (mm/dd/yyyy) }\end{array}$} & \multirow{2}{*}{$\begin{array}{l}\text { Sweeper } \\
\text { cleaning }\end{array}$} & \multicolumn{8}{|c|}{$\begin{array}{c}\text { Street-dirt yield } \\
\text { (pounds per curb-mile) }\end{array}$} \\
\hline & & $>2,000 \mu \mathrm{m}$ & $1,000-2,000 \mu \mathrm{m}$ & $500-1,000 \mu \mathrm{m}$ & $250-500 \mu \mathrm{m}$ & $125-250 \mu \mathrm{m}$ & $63-125 \mu \mathrm{m}$ & $<63 \mu \mathrm{m}$ & Total \\
\hline 04/27/2004 & Pre & 3 & 11 & 21 & 54 & 30 & 11 & 5 & 136 \\
\hline $04 / 28 / 2004$ & Post & 5 & 7 & 15 & 45 & 33 & 18 & 16 & 140 \\
\hline $05 / 04 / 2004$ & Pre & 13 & 17 & 31 & 78 & 60 & 34 & 24 & 258 \\
\hline 05/05/2004 & Post & 9 & 10 & 18 & 51 & 41 & 28 & 30 & 186 \\
\hline 05/19/2004 & Pre & 13 & 13 & 14 & 21 & 12 & 4 & 2 & 78 \\
\hline 05/19/2004 & Post & 3 & 4 & 7 & 19 & 15 & 5 & 3 & 57 \\
\hline $05 / 26 / 2004$ & Pre & 21 & 23 & 25 & 44 & 30 & 7 & 2 & 152 \\
\hline $05 / 27 / 2004$ & Post & 9 & 9 & 11 & 22 & 17 & 5 & 2 & 74 \\
\hline 06/02/2004 & Pre & 16 & 17 & 16 & 22 & 16 & 5 & 4 & 95 \\
\hline 06/03/2004 & Post & 12 & 13 & 13 & 19 & 14 & 6 & 4 & 81 \\
\hline 06/08/2004 & Pre & 17 & 19 & 19 & 26 & 19 & 9 & 7 & 115 \\
\hline 06/10/2004 & Post & -- & -- & -- & -- & -- & -- & -- & -- \\
\hline $06 / 15 / 2004$ & Pre & 18 & 17 & 16 & 20 & 12 & 7 & 3 & 93 \\
\hline $06 / 16 / 2004$ & Post & 9 & 8 & 10 & 16 & 11 & 6 & 2 & 62 \\
\hline $06 / 22 / 2004$ & Pre & 11 & 11 & 10 & 12 & 7 & 3 & 2 & 56 \\
\hline $06 / 23 / 2004$ & Post & -- & -- & -- & -- & -- & -- & -- & -- \\
\hline $06 / 29 / 2004$ & Pre & 12 & 13 & 13 & 18 & 12 & 5 & 4 & 77 \\
\hline 06/30/2004 & Post & 7 & 7 & 9 & 14 & 10 & 4 & 2 & 54 \\
\hline 07/07/2004 & Pre & 12 & 9 & 9 & 14 & 9 & 2 & 1 & 56 \\
\hline 07/08/2004 & Post & 8 & 8 & 9 & 15 & 11 & 4 & 2 & 56 \\
\hline 07/14/2004 & Pre & 14 & 13 & 14 & 21 & 14 & 6 & 4 & 85 \\
\hline 07/15/2004 & Post & 8 & 9 & 10 & 16 & 12 & 5 & 3 & 62 \\
\hline 07/20/2004 & Pre & 12 & 12 & 13 & 20 & 12 & 5 & 2 & 75 \\
\hline 07/21/2004 & Post & -- & -- & -- & -- & -- & -- & -- & -- \\
\hline 07/27/2004 & Pre & 16 & 18 & 17 & 23 & 16 & 9 & 8 & 106 \\
\hline $07 / 28 / 2004$ & Post & 11 & 16 & 10 & 17 & 10 & 5 & 5 & 76 \\
\hline 08/03/2004 & Pre & 13 & 16 & 14 & 16 & 9 & 4 & 2 & 74 \\
\hline 08/04/2004 & Post & -- & -- & -- & -- & -- & -- & -- & -- \\
\hline 08/10/2004 & Pre & 19 & 22 & 19 & 27 & 19 & 7 & 4 & 118 \\
\hline 08/11/2004 & Post & 9 & 11 & 11 & 18 & 13 & 5 & 3 & 71 \\
\hline 08/18/2004 & Pre & 38 & 35 & 25 & 22 & 13 & 5 & 2 & 141 \\
\hline 08/19/2004 & Post & -- & -- & -- & -- & -- & -- & -- & -- \\
\hline $08 / 31 / 2004$ & Pre & 29 & 22 & 18 & 19 & 12 & 5 & 4 & 108 \\
\hline 09/01/2004 & Post & 19 & 17 & 15 & 17 & 10 & 4 & 2 & 85 \\
\hline 09/07/2004 & Pre & 30 & 31 & 29 & 35 & 23 & 9 & 5 & 161 \\
\hline 09/08/2004 & Post & 11 & 14 & 14 & 18 & 13 & 6 & 4 & 81 \\
\hline
\end{tabular}


Appendix 1. Detailed street-dirt and water-quality data-Continued.

Appendix table 1-2. Air-sweeper basin street-dirt yield, in pounds per curb-mile, separated by particle size-Continued. [mm/dd/yyyy, month/day/year; $\mu \mathrm{m}$, micrometer; >, greater than; <, less than; NS, no sweeping in basin; --, no data]

\begin{tabular}{|c|c|c|c|c|c|c|c|c|c|}
\hline \multirow{2}{*}{$\begin{array}{c}\text { Date } \\
\text { (mm/dd/yyyy) }\end{array}$} & \multirow{2}{*}{$\begin{array}{l}\text { Sweeper } \\
\text { cleaning }\end{array}$} & \multicolumn{8}{|c|}{$\begin{array}{c}\text { Street-dirt yield } \\
\text { (pounds per curb-mile) }\end{array}$} \\
\hline & & $>2,000 \mu \mathrm{m}$ & $1,000-2,000 \mu \mathrm{m}$ & $500-1,000 \mu \mathrm{m}$ & $250-500 \mu \mathrm{m}$ & $125-250 \mu \mathrm{m}$ & $63-125 \mu \mathrm{m}$ & $<63 \mu \mathrm{m}$ & Total \\
\hline 09/16/2004 & Pre & 21 & 17 & 13 & 13 & 8 & 3 & 2 & 76 \\
\hline 09/17/2004 & Post & 11 & 13 & 12 & 13 & 7 & 4 & 2 & 62 \\
\hline $04 / 05 / 2005$ & Pre & 98 & 122 & 316 & 695 & 255 & 96 & 59 & 1,641 \\
\hline 04/05/2005 & Post & 39 & 55 & 183 & 453 & 171 & 61 & 44 & 1,005 \\
\hline $04 / 13 / 2005$ & Pre & 49 & 74 & 216 & 533 & 220 & 68 & 27 & 1,187 \\
\hline $04 / 14 / 2005$ & Post & 24 & 42 & 125 & 346 & 173 & 71 & 40 & 820 \\
\hline $04 / 21 / 2005$ & Pre & 41 & 61 & 160 & 394 & 186 & 75 & 44 & 962 \\
\hline $04 / 21 / 2005$ & Post & 14 & 23 & 70 & 219 & 124 & 57 & 39 & 546 \\
\hline $04 / 28 / 2005$ & Pre & 32 & 41 & 88 & 256 & 163 & 86 & 53 & 717 \\
\hline $04 / 28 / 2005$ & Post & 15 & 23 & 57 & 175 & 110 & 62 & 58 & 499 \\
\hline 05/05/2005 & Pre & 26 & 31 & 64 & 183 & 121 & 72 & 71 & 568 \\
\hline 05/05/2005 & Post & 15 & 19 & 47 & 143 & 98 & 57 & 55 & 434 \\
\hline 05/18/2005 & Pre & 24 & 34 & 49 & 117 & 81 & 43 & 28 & 374 \\
\hline 05/18/2005 & Post & 12 & 16 & 29 & 78 & 54 & 30 & 21 & 239 \\
\hline $05 / 25 / 2005$ & Pre & 29 & 45 & 55 & 98 & 71 & 36 & 18 & 351 \\
\hline $05 / 25 / 2005$ & Post & 10 & 22 & 27 & 55 & 40 & 22 & 15 & 192 \\
\hline 06/02/2005 & Pre & 20 & 40 & 42 & 72 & 54 & 32 & 26 & 285 \\
\hline $06 / 02 / 2005$ & Post & 11 & 21 & 27 & 54 & 44 & 28 & 20 & 205 \\
\hline $06 / 23 / 2005$ & Pre & 12 & 16 & 22 & 33 & 24 & 14 & 11 & 132 \\
\hline $06 / 23 / 2005$ & Post & 5 & 8 & 13 & 24 & 16 & 8 & 5 & 79 \\
\hline
\end{tabular}


Appendix 1. Detailed street-dirt and water-quality data-Continued.

Appendix table 1-3. High-frequency broom basin street-dirt yield, in pounds per curb-mile, separated by particle size.

$[\mathrm{mm} / \mathrm{dd} / \mathrm{yyyy}$, month/day/year; $\mu \mathrm{m}$, micrometer; >, greater than; <, less than; NS, no sweeping in basin; --, no data]

\begin{tabular}{|c|c|c|c|c|c|c|c|c|c|}
\hline \multirow{2}{*}{$\begin{array}{c}\text { Date } \\
\text { (mm/dd/ } \\
\text { yyyy) }\end{array}$} & \multirow{2}{*}{$\begin{array}{l}\text { Sweeper } \\
\text { cleaning }\end{array}$} & \multicolumn{8}{|c|}{$\begin{array}{c}\text { Street-dirt yield } \\
\text { (pounds per curb-mile) }\end{array}$} \\
\hline & & $>2,000 \mu \mathrm{m}$ & $1,000-2,000 \mu \mathrm{m}$ & $500-1,000 \mu \mathrm{m}$ & $250-500 \mu \mathrm{m}$ & $125-250 \mu \mathrm{m}$ & $63-125 \mu \mathrm{m}$ & $<63 \mu \mathrm{m}$ & Total \\
\hline 05/17/2002 & NS & 47 & 79 & 148 & 201 & 88 & 32 & 21 & 614 \\
\hline 05/24/2002 & NS & 47 & 83 & 144 & 186 & 87 & 32 & 27 & 606 \\
\hline 05/31/2002 & NS & 40 & 75 & 129 & 174 & 75 & 21 & 12 & 527 \\
\hline $06 / 07 / 2002$ & NS & 34 & 60 & 79 & 86 & 33 & 8 & 5 & 304 \\
\hline $06 / 14 / 2002$ & NS & 35 & 66 & 81 & 93 & 40 & 9 & 2 & 326 \\
\hline $06 / 20 / 2002$ & NS & 37 & 62 & 88 & 103 & 46 & 12 & 7 & 356 \\
\hline 06/28/2002 & NS & 29 & 47 & 68 & 78 & 35 & 9 & 5 & 270 \\
\hline $07 / 05 / 2002$ & NS & 37 & 60 & 102 & 136 & 64 & 17 & 10 & 427 \\
\hline 07/12/2002 & NS & 34 & 69 & 112 & 149 & 79 & 26 & 14 & 482 \\
\hline 07/19/2002 & NS & 38 & 58 & 88 & 118 & 63 & 21 & 15 & 401 \\
\hline 07/26/2002 & NS & 36 & 57 & 74 & 99 & 52 & 17 & 10 & 344 \\
\hline 08/02/2002 & NS & 42 & 67 & 86 & 105 & 49 & 15 & 9 & 373 \\
\hline 08/09/2002 & NS & 37 & 61 & 91 & 119 & 56 & 16 & 9 & 388 \\
\hline 08/16/2002 & NS & 32 & 49 & 67 & 80 & 38 & 11 & 6 & 282 \\
\hline 08/30/2002 & NS & 39 & 56 & 80 & 105 & 52 & 16 & 12 & 361 \\
\hline 09/06/2002 & NS & 32 & 51 & 70 & 86 & 43 & 14 & 8 & 303 \\
\hline 09/13/2002 & NS & 32 & 55 & 78 & 92 & 42 & 13 & 7 & 319 \\
\hline 09/27/2002 & NS & 32 & 58 & 79 & 93 & 47 & 16 & 8 & 333 \\
\hline 04/01/2003 & Pre & 125 & 245 & 612 & 960 & 337 & 94 & 55 & 2,428 \\
\hline 04/02/2003 & Post & 57 & 129 & 420 & 750 & 316 & 99 & 74 & 1,845 \\
\hline $04 / 15 / 2003$ & Pre & 121 & 202 & 515 & 883 & 357 & 116 & 119 & 2,313 \\
\hline $04 / 16 / 2003$ & Post & 41 & 73 & 234 & 469 & 264 & 95 & 78 & 1,254 \\
\hline $04 / 22 / 2003$ & Pre & 41 & 82 & 250 & 463 & 241 & 65 & 38 & 1,180 \\
\hline $04 / 23 / 2003$ & Post & 35 & 70 & 216 & 419 & 222 & 80 & 46 & 1,089 \\
\hline $04 / 29 / 2003$ & Pre & 37 & 65 & 203 & 396 & 257 & 96 & 77 & 1,131 \\
\hline $04 / 30 / 2003$ & Post & -- & -- & -- & -- & -- & -- & -- & -- \\
\hline 05/06/2003 & Pre & 34 & 56 & 152 & 268 & 132 & 33 & 20 & 694 \\
\hline 05/07/2003 & Post & -- & -- & -- & -- & -- & -- & -- & -- \\
\hline $05 / 12 / 2003$ & Pre & 25 & 43 & 96 & 152 & 68 & 16 & 9 & 410 \\
\hline 05/13/2003 & Post & 17 & 32 & 86 & 153 & 78 & 23 & 11 & 400 \\
\hline 05/20/2003 & Pre & 20 & 38 & 90 & 138 & 61 & 17 & 8 & 372 \\
\hline $05 / 21 / 2003$ & Post & 19 & 36 & 85 & 145 & 74 & 26 & 12 & 396 \\
\hline $05 / 27 / 2003$ & Pre & 24 & 48 & 114 & 203 & 118 & 43 & 28 & 577 \\
\hline 05/28/2003 & Post & -- & -- & -- & -- & -- & -- & -- & -- \\
\hline 06/03/2003 & Pre & 25 & 46 & 97 & 148 & 81 & 20 & 12 & 428 \\
\hline 06/04/2003 & Post & 19 & 36 & 83 & 144 & 83 & 29 & 13 & 407 \\
\hline $06 / 11 / 2003$ & Pre & 26 & 50 & 115 & 179 & 108 & 32 & 14 & 524 \\
\hline $06 / 12 / 2003$ & Post & 14 & 34 & 80 & 127 & 73 & 22 & 11 & 361 \\
\hline
\end{tabular}


Appendix 1. Detailed street-dirt and water-quality data-Continued.

Appendix table 1-3. High-frequency broom basin street-dirt yield, in pounds per curb-mile, separated by particle size—Continued. [mm/dd/yyyy, month/day/year; $\mu \mathrm{m}$, micrometer; >, greater than; <, less than; NS, no sweeping in basin; --, no data]

\begin{tabular}{|c|c|c|c|c|c|c|c|c|c|}
\hline \multirow{2}{*}{$\begin{array}{c}\text { Date } \\
\text { (mm/dd/ } \\
\text { yyyy) }\end{array}$} & \multirow{2}{*}{$\begin{array}{l}\text { Sweeper } \\
\text { cleaning }\end{array}$} & \multicolumn{8}{|c|}{$\begin{array}{l}\text { Street-dirt yield } \\
\text { (pounds per curb-mile) }\end{array}$} \\
\hline & & $>2,000 \mu \mathrm{m}$ & $1,000-2,000 \mu \mathrm{m}$ & $500-1,000 \mu \mathrm{m}$ & $250-500 \mu \mathrm{m}$ & $125-250 \mu \mathrm{m}$ & $63-125 \mu \mathrm{m}$ & $<63 \mu \mathrm{m}$ & Total \\
\hline $06 / 16 / 2003$ & Pre & 24 & 44 & 103 & 168 & 103 & 31 & 14 & 488 \\
\hline $06 / 17 / 2003$ & Post & 16 & 38 & 90 & 148 & 106 & 33 & 20 & 451 \\
\hline $06 / 26 / 2003$ & Pre & 13 & 28 & 54 & 69 & 33 & 8 & 3 & 208 \\
\hline $07 / 01 / 2003$ & Pre & 21 & 37 & 69 & 117 & 85 & 27 & 17 & 373 \\
\hline $07 / 02 / 2003$ & Post & 14 & 30 & 63 & 102 & 67 & 22 & 10 & 306 \\
\hline 07/09/2003 & Pre & 18 & 25 & 46 & 66 & 35 & 9 & 3 & 203 \\
\hline $07 / 11 / 2003$ & Post & 10 & 17 & 34 & 37 & 41 & 10 & 2 & 152 \\
\hline $07 / 16 / 2003$ & Pre & 15 & 22 & 41 & 66 & 42 & 15 & 7 & 208 \\
\hline 07/17/2003 & Post & 12 & 17 & 36 & 62 & 43 & 14 & 5 & 189 \\
\hline $07 / 22 / 2003$ & Pre & 14 & 19 & 34 & 53 & 34 & 9 & 3 & 167 \\
\hline $07 / 23 / 2003$ & Post & 14 & 22 & 39 & 59 & 36 & 12 & 5 & 186 \\
\hline 07/29/2003 & Pre & 15 & 25 & 41 & 66 & 50 & 15 & 9 & 222 \\
\hline 07/30/2003 & Post & 22 & 30 & 52 & 81 & 54 & 20 & 11 & 270 \\
\hline 08/05/2003 & Pre & 23 & 27 & 47 & 79 & 54 & 14 & 14 & 259 \\
\hline $08 / 12 / 2003$ & Pre & 18 & 34 & 58 & 94 & 62 & 23 & 15 & 305 \\
\hline 08/13/2003 & Post & 20 & 28 & 53 & 89 & 66 & 26 & 19 & 300 \\
\hline $08 / 19 / 2003$ & Pre & 23 & 36 & 63 & 106 & 71 & 30 & 19 & 347 \\
\hline $08 / 20 / 2003$ & Post & 15 & 28 & 55 & 96 & 73 & 30 & 21 & 317 \\
\hline $08 / 26 / 2003$ & Pre & 21 & 32 & 51 & 71 & 47 & 18 & 11 & 251 \\
\hline $08 / 27 / 2003$ & Post & 15 & 24 & 44 & 67 & 46 & 19 & 12 & 227 \\
\hline $09 / 02 / 2003$ & Pre & 19 & 29 & 50 & 73 & 47 & 18 & 10 & 246 \\
\hline 09/03/2003 & Post & 17 & 25 & 49 & 79 & 56 & 22 & 17 & 264 \\
\hline 09/09/2003 & Pre & 16 & 27 & 50 & 83 & 59 & 23 & 16 & 273 \\
\hline 09/10/2003 & Post & 14 & 25 & 46 & 71 & 50 & 20 & 15 & 241 \\
\hline $09 / 16 / 2003$ & Pre & 14 & 24 & 35 & 46 & 27 & 8 & 5 & 160 \\
\hline $09 / 17 / 2003$ & Post & 15 & 26 & 38 & 50 & 30 & 10 & 6 & 174 \\
\hline $09 / 23 / 2003$ & Pre & 17 & 28 & 41 & 44 & 36 & 8 & 4 & 179 \\
\hline $09 / 24 / 2003$ & Post & 14 & 25 & 41 & 55 & 32 & 12 & 6 & 186 \\
\hline 09/30/2003 & Pre & 18 & 29 & 44 & 61 & 38 & 15 & 9 & 214 \\
\hline $10 / 01 / 2003$ & Post & 18 & 28 & 47 & 68 & 46 & 19 & 11 & 238 \\
\hline $10 / 07 / 2003$ & Pre & 30 & 40 & 56 & 66 & 37 & 14 & 7 & 251 \\
\hline $10 / 08 / 2003$ & Post & 26 & 30 & 48 & 67 & 43 & 16 & 11 & 240 \\
\hline $04 / 06 / 2004$ & Pre & 70 & 125 & 216 & 276 & 92 & 24 & 11 & 812 \\
\hline $04 / 07 / 2004$ & Post & 66 & 111 & 227 & 354 & 138 & 51 & 35 & 982 \\
\hline $04 / 13 / 2004$ & Pre & 73 & 121 & 240 & 389 & 160 & 66 & 50 & 1,098 \\
\hline $04 / 16 / 2004$ & Post & 52 & 98 & 201 & 296 & 112 & 34 & 19 & 812 \\
\hline $04 / 20 / 2004$ & Pre & 61 & 105 & 174 & 232 & 91 & 29 & 17 & 709 \\
\hline $04 / 21 / 2004$ & Post & -- & -- & -- & -- & -- & -- & -- & -- \\
\hline
\end{tabular}


Appendix 1. Detailed street-dirt and water-quality data-Continued.

Appendix table 1-3. High-frequency broom basin street-dirt yield, in pounds per curb-mile, separated by particle size—Continued. [mm/dd/yyyy, month/day/year; $\mu \mathrm{m}$, micrometer; >, greater than; <, less than; NS, no sweeping in basin; --, no data]

\begin{tabular}{|c|c|c|c|c|c|c|c|c|c|}
\hline \multirow{2}{*}{$\begin{array}{c}\text { Date } \\
\text { (mm/dd/ } \\
\text { yyyy) }\end{array}$} & \multirow{2}{*}{$\begin{array}{l}\text { Sweeper } \\
\text { cleaning }\end{array}$} & \multicolumn{8}{|c|}{$\begin{array}{c}\text { Street-dirt yield } \\
\text { (pounds per curb-mile) }\end{array}$} \\
\hline & & $>2,000 \mu \mathrm{m}$ & $1,000-2,000 \mu \mathrm{m}$ & $500-1,000 \mu \mathrm{m}$ & $250-500 \mu \mathrm{m}$ & $125-250 \mu \mathrm{m}$ & $63-125 \mu \mathrm{m}$ & $<63 \mu \mathrm{m}$ & Total \\
\hline $04 / 27 / 2004$ & Pre & 55 & 95 & 165 & 214 & 80 & 24 & 14 & 647 \\
\hline 04/28/2004 & Post & 41 & 82 & 155 & 224 & 92 & 32 & 21 & 647 \\
\hline 05/04/2004 & Pre & 52 & 89 & 155 & 222 & 98 & 36 & 25 & 678 \\
\hline 05/05/2004 & Post & 47 & 83 & 155 & 234 & 109 & 44 & 43 & 715 \\
\hline 05/19/2004 & Pre & 36 & 66 & 105 & 151 & 58 & 12 & 5 & 432 \\
\hline 05/19/2004 & Post & 26 & 52 & 91 & 145 & 66 & 16 & 6 & 404 \\
\hline 05/26/2004 & Pre & 35 & 55 & 77 & 109 & 54 & 11 & 3 & 344 \\
\hline 05/27/2004 & Post & 30 & 45 & 66 & 108 & 57 & 15 & 5 & 326 \\
\hline 06/02/2004 & Pre & 31 & 51 & 72 & 111 & 57 & 13 & 4 & 339 \\
\hline 06/04/2004 & Post & 27 & 43 & 68 & 106 & 55 & 14 & 6 & 319 \\
\hline 06/08/2004 & Pre & 26 & 44 & 70 & 114 & 59 & 17 & 6 & 337 \\
\hline 06/10/2004 & Post & -- & -- & -- & -- & -- & -- & -- & -- \\
\hline 06/15/2004 & Pre & 20 & 41 & 62 & 87 & 44 & 11 & 4 & 269 \\
\hline $06 / 16 / 2004$ & Post & 17 & 33 & 57 & 85 & 41 & 11 & 4 & 247 \\
\hline $06 / 22 / 2004$ & Pre & 19 & 33 & 46 & 75 & 28 & 13 & 4 & 218 \\
\hline $06 / 23 / 2004$ & Post & -- & -- & -- & -- & -- & -- & -- & -- \\
\hline 06/29/2004 & Pre & 20 & 34 & 58 & 80 & 43 & 11 & 6 & 251 \\
\hline 06/30/2004 & Post & 18 & 33 & 62 & 95 & 52 & 14 & 7 & 281 \\
\hline 07/07/2004 & Pre & 16 & 24 & 34 & 45 & 20 & 4 & 2 & 144 \\
\hline 07/08/2004 & Post & 17 & 28 & 45 & 67 & 34 & 9 & 3 & 202 \\
\hline $07 / 14 / 2004$ & Pre & 21 & 40 & 49 & 75 & 40 & 10 & 8 & 243 \\
\hline $07 / 15 / 2004$ & Post & 17 & 31 & 53 & 85 & 45 & 13 & 7 & 251 \\
\hline $07 / 20 / 2004$ & Pre & 19 & 33 & 46 & 66 & 32 & 9 & 4 & 209 \\
\hline $07 / 21 / 2004$ & Post & -- & -- & -- & -- & -- & -- & -- & -- \\
\hline $07 / 27 / 2004$ & Pre & 18 & 34 & 47 & 68 & 36 & 11 & 5 & 221 \\
\hline $07 / 28 / 2004$ & Post & 17 & 30 & 45 & 68 & 35 & 11 & 6 & 212 \\
\hline 08/03/2004 & Pre & 18 & 33 & 41 & 53 & 24 & 5 & 3 & 178 \\
\hline 08/04/2004 & Post & -- & -- & -- & -- & -- & -- & -- & -- \\
\hline 08/10/2004 & Pre & 21 & 34 & 44 & 61 & 31 & 9 & 4 & 204 \\
\hline $08 / 11 / 2004$ & Post & 16 & 26 & 40 & 59 & 32 & 9 & 5 & 187 \\
\hline 08/18/2004 & Pre & 14 & 20 & 28 & 36 & 16 & 4 & 3 & 122 \\
\hline 08/19/2004 & Post & -- & -- & -- & -- & -- & -- & -- & -- \\
\hline $08 / 31 / 2004$ & Pre & 25 & 26 & 43 & 63 & 27 & 7 & 4 & 195 \\
\hline 09/01/2004 & Post & 18 & 23 & 31 & 36 & 16 & 4 & 2 & 129 \\
\hline 09/07/2004 & Pre & 21 & 31 & 42 & 50 & 22 & 6 & 3 & 176 \\
\hline 09/08/2004 & Post & 14 & 22 & 35 & 48 & 25 & 8 & 5 & 156 \\
\hline
\end{tabular}


Appendix 1. Detailed street-dirt and water-quality data-Continued.

Appendix table 1-3. High-frequency broom basin street-dirt yield, in pounds per curb-mile, separated by particle size—Continued. [mm/dd/yyyy, month/day/year; $\mu \mathrm{m}$, micrometer; >, greater than; <, less than; NS, no sweeping in basin; --, no data]

\begin{tabular}{|c|c|c|c|c|c|c|c|c|c|}
\hline \multirow{2}{*}{$\begin{array}{c}\text { Date } \\
\text { (mm/dd/ } \\
\text { yyyy) }\end{array}$} & \multirow{2}{*}{$\begin{array}{l}\text { Sweeper } \\
\text { cleaning }\end{array}$} & \multicolumn{8}{|c|}{$\begin{array}{c}\text { Street-dirt yield } \\
\text { (pounds per curb-mile) }\end{array}$} \\
\hline & & $>2,000 \mu \mathrm{m}$ & $1,000-2,000 \mu \mathrm{m}$ & $500-1,000 \mu \mathrm{m}$ & $250-500 \mu \mathrm{m}$ & $125-250 \mu \mathrm{m}$ & $63-125 \mu \mathrm{m}$ & $<63 \mu \mathrm{m}$ & Tota \\
\hline 09/16/2004 & Pre & 14 & 20 & 29 & 31 & 12 & 3 & 2 & 111 \\
\hline 09/17/2004 & Post & 13 & 19 & 25 & 29 & 12 & 3 & 2 & 102 \\
\hline $04 / 05 / 2005$ & NS & 65 & 97 & 260 & 588 & 265 & 108 & 73 & 1,457 \\
\hline $04 / 13 / 2005$ & NS & 55 & 74 & 176 & 334 & 136 & 44 & 19 & 838 \\
\hline $04 / 21 / 2005$ & NS & 53 & 77 & 175 & 342 & 167 & 63 & 36 & 914 \\
\hline $04 / 28 / 2005$ & NS & 46 & 75 & 173 & 340 & 168 & 75 & 55 & 932 \\
\hline $05 / 05 / 2005$ & NS & 52 & 76 & 184 & 371 & 188 & 83 & 72 & 1,026 \\
\hline $05 / 18 / 2005$ & NS & 46 & 66 & 127 & 229 & 116 & 49 & 31 & 664 \\
\hline $05 / 25 / 2005$ & NS & 57 & 81 & 133 & 222 & 120 & 49 & 29 & 690 \\
\hline $06 / 02 / 2005$ & NS & 60 & 85 & 143 & 224 & 113 & 47 & 34 & 706 \\
\hline
\end{tabular}


Appendix 1. Detailed street-dirt and water-quality data-Continued.

Appendix table 1-4. Low-frequency broom basin street-dirt yield, in pounds per curb-mile, separated by particle size.

[mm/dd/yyyy, month/day/year; $\mu \mathrm{m}$, micrometer; >, greater than; <, less than]

\begin{tabular}{|c|c|c|c|c|c|c|c|c|}
\hline \multirow{2}{*}{$\begin{array}{c}\text { Date } \\
\text { (mm/dd/yyyy) }\end{array}$} & \multicolumn{8}{|c|}{$\begin{array}{l}\text { Street-dirt yield } \\
\text { (pounds per curb-mile) }\end{array}$} \\
\hline & $>2,000 \mu \mathrm{m}$ & $1,000-2,000 \mu \mathrm{m}$ & $500-1,000 \mu \mathrm{m}$ & $250-500 \mu \mathrm{m}$ & $125-250 \mu \mathrm{m}$ & $63-125 \mu \mathrm{m}$ & $<63 \mu \mathrm{m}$ & Total \\
\hline $06 / 20 / 2002$ & 74 & 93 & 143 & 189 & 84 & 24 & 9 & 617 \\
\hline $06 / 28 / 2002$ & 64 & 69 & 102 & 152 & 74 & 23 & 11 & 495 \\
\hline $07 / 05 / 2002$ & 54 & 78 & 115 & 164 & 87 & 31 & 19 & 549 \\
\hline $07 / 12 / 2002$ & 86 & 112 & 177 & 275 & 148 & 55 & 39 & 891 \\
\hline $07 / 19 / 2002$ & 53 & 70 & 111 & 171 & 100 & 41 & 25 & 571 \\
\hline $07 / 26 / 2002$ & 67 & 74 & 105 & 161 & 88 & 33 & 18 & 547 \\
\hline 08/02/2002 & 84 & 93 & 138 & 209 & 109 & 44 & 27 & 703 \\
\hline 08/09/2002 & 77 & 84 & 125 & 179 & 96 & 40 & 26 & 626 \\
\hline 08/16/2002 & 63 & 69 & 93 & 139 & 77 & 29 & 17 & 486 \\
\hline 08/30/2002 & 50 & 63 & 92 & 138 & 77 & 32 & 20 & 472 \\
\hline 09/06/2002 & 49 & 62 & 92 & 139 & 86 & 37 & 23 & 489 \\
\hline $09 / 13 / 2002$ & 48 & 67 & 101 & 145 & 81 & 32 & 17 & 490 \\
\hline 09/27/2002 & 70 & 94 & 131 & 200 & 119 & 44 & 25 & 683 \\
\hline $04 / 02 / 2003$ & 136 & 188 & 389 & 618 & 266 & 96 & 59 & 1,753 \\
\hline $04 / 15 / 2003$ & 213 & 272 & 494 & 706 & 324 & 122 & 119 & 2,250 \\
\hline $04 / 23 / 2003$ & 79 & 111 & 227 & 389 & 203 & 73 & 51 & 1,132 \\
\hline $04 / 29 / 2003$ & 83 & 121 & 265 & 472 & 260 & 92 & 99 & 1,392 \\
\hline 05/13/2003 & 54 & 100 & 185 & 268 & 115 & 36 & 13 & 770 \\
\hline $05 / 21 / 2003$ & 46 & 78 & 147 & 246 & 122 & 40 & 27 & 707 \\
\hline $05 / 27 / 2003$ & 51 & 89 & 168 & 268 & 157 & 40 & 48 & 821 \\
\hline 06/04/2003 & 65 & 93 & 175 & 307 & 166 & 58 & 27 & 891 \\
\hline $06 / 12 / 2003$ & 35 & 61 & 127 & 182 & 98 & 37 & 20 & 561 \\
\hline $06 / 17 / 2003$ & 48 & 86 & 166 & 274 & 150 & 60 & 30 & 813 \\
\hline $06 / 26 / 2003$ & 38 & 52 & 85 & 133 & 72 & 27 & 16 & 422 \\
\hline $07 / 02 / 2003$ & 43 & 57 & 105 & 192 & 125 & 56 & 36 & 613 \\
\hline $07 / 11 / 2003$ & 38 & 53 & 89 & 134 & 74 & 24 & 9 & 421 \\
\hline $07 / 16 / 2003$ & 47 & 54 & 82 & 131 & 86 & 36 & 17 & 453 \\
\hline $07 / 23 / 2003$ & 43 & 47 & 74 & 126 & 89 & 44 & 22 & 446 \\
\hline $07 / 30 / 2003$ & 44 & 62 & 104 & 187 & 126 & 52 & 30 & 603 \\
\hline 08/05/2003 & 44 & 60 & 97 & 170 & 125 & 52 & 41 & 590 \\
\hline 08/13/2003 & 40 & 54 & 84 & 153 & 117 & 55 & 37 & 540 \\
\hline 08/20/2003 & 44 & 62 & 106 & 193 & 141 & 69 & 45 & 659 \\
\hline $08 / 27 / 2003$ & 33 & 47 & 77 & 139 & 103 & 48 & 28 & 475 \\
\hline 09/03/2003 & 35 & 48 & 75 & 124 & 90 & 44 & 31 & 448 \\
\hline 09/10/2003 & 38 & 62 & 90 & 154 & 108 & 57 & 39 & 548 \\
\hline 09/17/2003 & 32 & 45 & 66 & 112 & 80 & 32 & 17 & 385 \\
\hline
\end{tabular}


Appendix 1. Detailed street-dirt and water-quality data-Continued.

Appendix table 1-4. Low-frequency broom basin street-dirt yield, in pounds per curb-mile, separated by particle sizeContinued.

[mm/dd/yyyy, month/day/year; $\mu \mathrm{m}$, micrometer; $>$, greater than; <, less than]

\begin{tabular}{|c|c|c|c|c|c|c|c|c|}
\hline \multirow{2}{*}{$\begin{array}{c}\text { Date } \\
\text { (mm/dd/yyyy) }\end{array}$} & \multicolumn{8}{|c|}{$\begin{array}{c}\text { Street-dirt yield } \\
\text { (pounds per curb-mile) }\end{array}$} \\
\hline & $>2,000 \mu \mathrm{m}$ & $1,000-2,000 \mu \mathrm{m}$ & $500-1,000 \mu \mathrm{m}$ & $250-500 \mu \mathrm{m}$ & $125-250 \mu \mathrm{m}$ & $63-125 \mu \mathrm{m}$ & $<63 \mu \mathrm{m}$ & Total \\
\hline 09/24/2003 & 25 & 38 & 61 & 107 & 78 & 40 & 25 & 375 \\
\hline $10 / 01 / 2003$ & 35 & 50 & 74 & 126 & 92 & 45 & 24 & 446 \\
\hline $10 / 08 / 2003$ & 48 & 63 & 88 & 161 & 107 & 54 & 32 & 552 \\
\hline $04 / 06 / 2004$ & 90 & 120 & 213 & 320 & 94 & 25 & 11 & 873 \\
\hline $04 / 13 / 2004$ & 90 & 124 & 250 & 456 & 154 & 70 & 50 & 1,194 \\
\hline $04 / 27 / 2004$ & 78 & 108 & 190 & 303 & 107 & 35 & 19 & 841 \\
\hline 05/04/2004 & 60 & 93 & 175 & 303 & 124 & 53 & 32 & 840 \\
\hline 05/19/2004 & 56 & 79 & 122 & 194 & 76 & 22 & 8 & 557 \\
\hline $05 / 26 / 2004$ & 49 & 60 & 82 & 151 & 82 & 26 & 9 & 460 \\
\hline $06 / 02 / 2004$ & 53 & 62 & 85 & 150 & 77 & 23 & 6 & 455 \\
\hline 06/08/2004 & 57 & 81 & 95 & 166 & 131 & 35 & 14 & 580 \\
\hline $06 / 15 / 2004$ & 47 & 57 & 75 & 121 & 71 & 27 & 9 & 407 \\
\hline $06 / 22 / 2004$ & 42 & 53 & 72 & 115 & 57 & 22 & 7 & 367 \\
\hline $06 / 30 / 2004$ & 45 & 55 & 74 & 127 & 87 & 36 & 19 & 443 \\
\hline 07/09/2004 & 43 & 50 & 59 & 98 & 65 & 23 & 9 & 346 \\
\hline $07 / 14 / 2004$ & 39 & 47 & 61 & 111 & 76 & 31 & 17 & 381 \\
\hline $07 / 28 / 2004$ & 43 & 53 & 58 & 88 & 60 & 26 & 14 & 342 \\
\hline 08/03/2004 & 38 & 45 & 49 & 74 & 45 & 15 & 7 & 273 \\
\hline 08/10/2004 & 38 & 49 & 57 & 90 & 58 & 23 & 11 & 326 \\
\hline $09 / 02 / 2004$ & 37 & 44 & 50 & 76 & 46 & 16 & 5 & 274 \\
\hline 09/08/2004 & 40 & 48 & 54 & 82 & 58 & 23 & 8 & 313 \\
\hline $09 / 17 / 2004$ & 34 & 42 & 43 & 55 & 30 & 11 & 4 & 220 \\
\hline
\end{tabular}


Appendix 1. Detailed street-dirt and water-quality data-Continued.

Appendix table 1-5. Runoff-event characteristics for the control basin.

[mm/dd/yyyy, month/day/year; hh:mm, hour:minute; $\mathrm{ft}^{3}$, cubic feet; \%, percent; $\mathrm{ft}^{3} / \mathrm{s}$, cubic foot per second; --, data not available]

\begin{tabular}{|c|c|c|c|c|c|c|c|c|c|c|}
\hline Sample ID & $\begin{array}{l}\text { Start date } \\
\text { (mm/dd/yyyy) }\end{array}$ & $\begin{array}{c}\text { Start } \\
\text { time } \\
\text { (hh:mm) }\end{array}$ & $\begin{array}{c}\text { End date } \\
\text { (mm/dd/yyyy) }\end{array}$ & $\begin{array}{l}\text { End time } \\
\text { (hh:mm) }\end{array}$ & $\begin{array}{c}\text { Duration } \\
\text { (hours) }\end{array}$ & $\begin{array}{l}\text { Total event } \\
\text { volume } \\
\left(\mathrm{ft}^{3}\right)\end{array}$ & $\begin{array}{c}\text { Runoff } \\
(\%)\end{array}$ & $\begin{array}{l}\text { Peak } \\
\text { flow } \\
\left(\mathrm{ft}^{3} / \mathbf{s}\right)\end{array}$ & $\begin{array}{c}\text { Volume } \\
\text { of storm } \\
\text { sampled } \\
(\%)\end{array}$ & $\begin{array}{l}\text { Antecedent } \\
\text { dry time } \\
\text { (days) }\end{array}$ \\
\hline 1 & $08 / 25 / 2001$ & $02: 13$ & 08/25/2001 & $15: 30$ & 13.28 & 64,915 & 12 & 29.1 & 84 & \\
\hline 2 & 09/07/2001 & $12: 33$ & 09/09/2001 & $17: 00$ & 52.45 & 81,761 & 12 & 22.4 & 93 & 12.88 \\
\hline 3 & 09/17/2001 & 05:51 & 09/18/2001 & 02:00 & 20.15 & 24,018 & 14 & 4.8 & 94 & 7.54 \\
\hline 4 & 09/19/2001 & $00: 14$ & 09/19/2001 & $13: 13$ & 12.98 & 31,156 & 12 & 2.0 & 96 & .93 \\
\hline 5 & 09/20/2001 & 20:09 & 09/20/2001 & $22: 15$ & 2.10 & 9,859 & 10 & 3.6 & 98 & 1.29 \\
\hline 6 & $10 / 22 / 2001$ & $14: 00$ & $10 / 22 / 2001$ & $23: 32$ & 9.53 & 61,291 & 12 & 11.7 & 93 & 31.66 \\
\hline 7 & $10 / 24 / 2001$ & 07:54 & $10 / 24 / 2001$ & $22: 00$ & 14.10 & 9,058 & 10 & 1.4 & 95 & 1.35 \\
\hline 8 & $11 / 23 / 2001$ & $18: 45$ & $11 / 25 / 2001$ & 03:00 & 32.25 & 35,158 & 10 & 3.8 & 98 & 29.86 \\
\hline 9 & $02 / 18 / 2002$ & $12: 00$ & $02 / 19 / 2002$ & 11:05 & 23.08 & 33,976 & -- & 1.9 & 98 & 7.79 \\
\hline 10 & $02 / 19 / 2002$ & $13: 38$ & $02 / 21 / 2002$ & 01:00 & 35.37 & 61,161 & -- & 4.6 & 98 & .11 \\
\hline 11 & 03/08/2002 & 04:18 & 03/09/2002 & 11:00 & 30.70 & 66,993 & -- & 4.0 & 98 & 15.14 \\
\hline 12 & 04/07/2002 & $03: 45$ & 04/09/2002 & 04:00 & 48.25 & 92,387 & 17 & 3.0 & 97 & 28.70 \\
\hline 13 & 04/18/2002 & $07: 54$ & 04/18/2002 & $23: 51$ & 15.95 & 49,160 & 19 & 22.4 & 98 & 9.16 \\
\hline 14 & $05 / 01 / 2002$ & $12: 17$ & 05/02/2002 & 02:00 & 13.72 & 14,405 & 11 & 2.5 & 89 & 12.52 \\
\hline 15 & $05 / 11 / 2002$ & $10: 43$ & $05 / 12 / 2002$ & $02: 38$ & 15.92 & 28,523 & 13 & 7.0 & 91 & 9.36 \\
\hline 16 & $05 / 25 / 2002$ & 05:39 & $05 / 25 / 2002$ & $13: 00$ & 7.35 & 24,387 & 12 & 3.0 & 92 & 13.13 \\
\hline 17 & 05/28/2002 & $21: 16$ & 05/29/2002 & 05:27 & 8.18 & 34,751 & 15 & 25.2 & 97 & 3.34 \\
\hline 18 & $06 / 02 / 2002$ & 18:02 & 06/03/2002 & $08: 45$ & 14.72 & 58,339 & 20 & 19.7 & 100 & 4.52 \\
\hline 19 & 06/03/2002 & $21: 45$ & 06/04/2002 & $13: 48$ & 16.05 & 98,629 & 22 & 6.2 & 97 & .54 \\
\hline 20 & $06 / 10 / 2002$ & 19:04 & 06/10/2002 & $20: 32$ & 1.47 & 17,120 & 23 & 12.7 & 82 & 6.22 \\
\hline 21 & $06 / 26 / 2002$ & $04: 17$ & 06/26/2002 & 05:00 & .72 & 20,225 & 12 & 22.4 & 98 & 15.32 \\
\hline 22 & $07 / 22 / 2002$ & 01:08 & $07 / 22 / 2002$ & 08:04 & 6.93 & 31,555 & 12 & 7.6 & 82 & 25.84 \\
\hline 23 & 08/17/2002 & 07:06 & 08/17/2002 & 07:46 & .67 & 11,805 & 14 & 8.4 & 86 & 3.95 \\
\hline 24 & $08 / 21 / 2002$ & $18: 41$ & $08 / 22 / 2002$ & $06: 45$ & 12.07 & 36,228 & 9 & 10.5 & 92 & 4.45 \\
\hline 25 & $09 / 02 / 2002$ & $04: 28$ & 09/02/2002 & 08:56 & 4.47 & 47,477 & 14 & 5.8 & 95 & 10.90 \\
\hline 26 & 09/19/2002 & 01:05 & 09/19/2002 & 06:00 & 4.92 & 19,617 & 12 & 3.0 & 96 & 16.67 \\
\hline 27 & 09/19/2002 & $13: 23$ & 09/19/2002 & $13: 55$ & .53 & 13,622 & 13 & 13.2 & 90 & .31 \\
\hline 28 & 09/20/2002 & $06: 32$ & $09 / 20 / 2002$ & 09:49 & 3.28 & 11,702 & 9 & 6.0 & 99 & .69 \\
\hline 29 & $10 / 04 / 2002$ & 01:34 & $10 / 04 / 2002$ & $12: 00$ & 10.43 & 25,030 & 6 & 5.6 & 89 & 4.81 \\
\hline 30 & $10 / 25 / 2002$ & 01:03 & $10 / 25 / 2002$ & $23: 41$ & 22.63 & 16,093 & 11 & 1.0 & 92 & 20.54 \\
\hline 31 & $12 / 17 / 2002$ & $23: 22$ & $12 / 18 / 2002$ & $17: 00$ & 17.63 & 35,301 & 16 & 3.7 & 97 & 52.99 \\
\hline 32 & $03 / 27 / 2003$ & $08: 29$ & $03 / 28 / 2003$ & $11: 44$ & 27.25 & 28,142 & 16 & 3.4 & 98 & 98.65 \\
\hline 33 & $04 / 30 / 2003$ & $06: 24$ & 04/30/2003 & $14: 00$ & 7.60 & 24,628 & 11 & 4.6 & 91 & 32.78 \\
\hline 34 & $04 / 30 / 2003$ & $20: 51$ & $04 / 30 / 2003$ & $23: 46$ & 2.92 & 54,258 & 14 & 11.3 & 94 & .29 \\
\hline 35 & 05/04/2003 & $19: 39$ & 05/05/2003 & 10:00 & 14.35 & 25,729 & 11 & 1.7 & 99 & 3.83 \\
\hline 36 & 05/08/2003 & $22: 46$ & 05/09/2003 & 02:37 & 3.85 & 17,808 & 11 & 1.8 & 74 & 3.53 \\
\hline 37 & 05/10/2003 & 20:07 & 05/11/2003 & 19:05 & 22.97 & 23,164 & 10 & 4.0 & 96 & 1.73 \\
\hline
\end{tabular}


Appendix 1. Detailed street-dirt and water-quality data-Continued.

Appendix table 1-5. Runoff-event characteristics for the control basin-Continued.

[mm/dd/yyyy, month/day/year; hh:mm, hour:minute; $\mathrm{ft}^{3}$, cubic feet; \%, percent; $\mathrm{ft}^{3} / \mathrm{s}$, cubic foot per second; --, data not available]

\begin{tabular}{|c|c|c|c|c|c|c|c|c|c|c|}
\hline Sample ID & $\begin{array}{c}\text { Start date } \\
(\mathrm{mm} / \mathrm{dd} / \mathrm{yyyy})\end{array}$ & $\begin{array}{c}\text { Start } \\
\text { time } \\
\text { (hh:mm) }\end{array}$ & $\begin{array}{c}\text { End date } \\
\text { (mm/dd/yyyy) }\end{array}$ & $\begin{array}{l}\text { End time } \\
\text { (hh:mm) }\end{array}$ & $\begin{array}{l}\text { Duration } \\
\text { (hours) }\end{array}$ & $\begin{array}{c}\text { Total event } \\
\text { volume } \\
\left(\mathrm{ft}^{3}\right)\end{array}$ & $\begin{array}{c}\text { Runoff } \\
(\%)\end{array}$ & $\begin{array}{l}\text { Peak } \\
\text { flow } \\
\left(\mathrm{ft}^{3} / \mathrm{s}\right)\end{array}$ & $\begin{array}{c}\text { Volume } \\
\text { of storm } \\
\text { sampled } \\
(\%)\end{array}$ & $\begin{array}{l}\text { Antecedent } \\
\text { dry time } \\
\text { (days) }\end{array}$ \\
\hline 38 & 05/14/2003 & $06: 25$ & 05/14/2003 & $15: 58$ & 9.55 & 12,005 & 10 & 1.0 & 91 & 2.47 \\
\hline 39 & 05/19/2003 & $13: 05$ & 05/20/2003 & 02:02 & 12.95 & 18,178 & 13 & 3.6 & 80 & 4.88 \\
\hline 40 & 05/30/2003 & $17: 33$ & 05/30/2003 & $17: 55$ & .37 & 9,604 & 5 & 10.7 & 86 & 10.65 \\
\hline 41 & $07 / 15 / 2003$ & $01: 37$ & 07/15/2003 & $02: 22$ & .75 & 40,338 & 7 & 12.4 & 89 & 16.25 \\
\hline 42 & $07 / 21 / 2003$ & 01:54 & $07 / 21 / 2003$ & 03:00 & 1.10 & 14,069 & 11 & 1.9 & 98 & 5.98 \\
\hline 43 & 08/05/2003 & $17: 24$ & 08/05/2003 & 18:00 & .60 & 10,411 & 8 & 7.9 & 68 & 15.60 \\
\hline 44 & $09 / 12 / 2003$ & $13: 00$ & $09 / 12 / 2003$ & $19: 02$ & 6.03 & 6,944 & 4 & 2.4 & 100 & 37.79 \\
\hline 45 & 09/13/2003 & $05: 14$ & 09/14/2003 & 09:01 & 27.78 & 89,497 & 8 & 5.1 & 97 & .42 \\
\hline 46 & $10 / 13 / 2003$ & $22: 27$ & $10 / 14 / 2003$ & $11: 00$ & 12.55 & 11,534 & 6 & 1.1 & 96 & 1.98 \\
\hline 47 & $10 / 24 / 2003$ & $15: 56$ & $10 / 24 / 2003$ & $23: 00$ & 7.07 & 13,608 & 6 & 2.4 & 91 & 10.21 \\
\hline 48 & $11 / 01 / 2003$ & $21: 10$ & $11 / 02 / 2003$ & 20:00 & 22.83 & 46,172 & 9 & 4.0 & 82 & 7.92 \\
\hline 49 & $11 / 03 / 2003$ & $06: 13$ & $11 / 04 / 2003$ & $10: 00$ & 27.78 & 119,111 & 12 & 18.0 & 92 & .43 \\
\hline 50 & $11 / 17 / 2003$ & $22: 10$ & $11 / 18 / 2003$ & $12: 00$ & 13.83 & 12,476 & 7 & 2.6 & 99 & 13.51 \\
\hline 51 & $11 / 22 / 2003$ & $22: 54$ & $11 / 23 / 2003$ & 11:00 & 12.10 & 55,866 & 11 & 6.3 & 100 & 4.45 \\
\hline 52 & $12 / 09 / 2003$ & $12: 51$ & $12 / 10 / 2003$ & $12: 01$ & 23.17 & 56,324 & 10 & 3.4 & 100 & 16.08 \\
\hline 53 & $02 / 20 / 2004$ & 05:00 & $02 / 20 / 2004$ & $19: 00$ & 14.00 & 27,242 & -- & 1.7 & 98 & 71.71 \\
\hline 54 & 03/04/2004 & $18: 11$ & 03/05/2004 & $12: 48$ & 18.62 & 59,046 & 15 & 4.0 & 99 & 12.97 \\
\hline 55 & 03/25/2004 & $20: 51$ & 03/26/2004 & 08:00 & 11.15 & 39,640 & 8 & 8.5 & 98 & 20.34 \\
\hline 56 & $04 / 20 / 2004$ & $08: 26$ & $04 / 21 / 2004$ & $15: 00$ & 30.57 & 30,093 & 12 & 2.5 & 71 & 25.02 \\
\hline 57 & 05/08/2004 & $22: 32$ & 05/09/2004 & 02:00 & 3.47 & 13,677 & 7 & 8.6 & 95 & 17.31 \\
\hline 58 & 05/10/2004 & $03: 58$ & 05/10/2004 & $17: 00$ & 13.03 & 11,854 & 8 & 6.9 & 92 & 1.08 \\
\hline 60 & 05/17/2004 & $20: 25$ & 05/18/2004 & 02:00 & 5.58 & 19,215 & 7 & 20.0 & 90 & 7.14 \\
\hline 61 & $05 / 21 / 2004$ & $07: 36$ & $05 / 21 / 2004$ & 10:00 & 2.40 & 15,422 & 5 & 9.0 & 100 & 3.23 \\
\hline 62 & $05 / 21 / 2004$ & $16: 36$ & $05 / 22 / 2004$ & $10: 00$ & 17.40 & 99,204 & 10 & 21.0 & 60 & .28 \\
\hline 63 & 05/29/2004 & $08: 16$ & $05 / 31 / 2004$ & $17: 00$ & 56.73 & 36,634 & 7 & 7.0 & 97 & 6.93 \\
\hline 64 & 06/10/2004 & $10: 59$ & 06/10/2004 & $14: 00$ & 3.02 & 6,679 & 6 & 2.3 & 96 & 9.75 \\
\hline 65 & $06 / 10 / 2004$ & $15: 17$ & $06 / 11 / 2004$ & 09:00 & 17.72 & 25,307 & 8 & 3.1 & 95 & .05 \\
\hline 66 & $06 / 24 / 2004$ & $08: 36$ & $06 / 24 / 2004$ & $13: 00$ & 4.40 & 7,785 & 8 & 2.2 & 93 & 12.98 \\
\hline 67 & 07/09/2004 & $11: 46$ & 07/09/2004 & $14: 00$ & 2.23 & 10,731 & 8 & 6.4 & 92 & 14.95 \\
\hline 68 & 07/16/2004 & $10: 37$ & 07/16/2004 & $18: 00$ & 7.38 & 17,410 & 7 & 8.8 & 88 & 6.86 \\
\hline 69 & 07/21/2004 & $08: 17$ & $07 / 21 / 2004$ & $12: 00$ & 3.72 & 9,037 & 7 & 1.9 & 96 & 4.60 \\
\hline 70 & 07/29/2004 & $15: 05$ & 07/30/2004 & $10: 00$ & 18.92 & 29,272 & 8 & 6.2 & 96 & 8.13 \\
\hline 71 & 08/03/2004 & $19: 41$ & 08/03/2004 & $23: 00$ & 3.32 & 23,985 & 9 & 23.0 & 97 & 1.28 \\
\hline 72 & 08/16/2004 & 20:06 & 08/17/2004 & 03:00 & 6.90 & 7,871 & 7 & 4.6 & 97 & 12.88 \\
\hline 73 & 08/18/2004 & $17: 42$ & 08/18/2004 & 20:00 & 2.30 & 9,556 & 6 & 10.0 & 90 & 1.61 \\
\hline 74 & $08 / 24 / 2004$ & $18: 00$ & $08 / 25 / 2004$ & 01:00 & 7.00 & 5,469 & 14 & 3.9 & 97 & .13 \\
\hline 75 & 08/27/2004 & $00: 52$ & 08/27/2004 & 03:00 & 2.13 & 4,113 & 4 & 3.7 & 88 & 1.99 \\
\hline
\end{tabular}


Appendix 1. Detailed street-dirt and water-quality data-Continued.

Appendix table 1-5. Runoff-event characteristics for the control basin—Continued.

[mm/dd/yyyy, month/day/year; hh:mm, hour:minute; $\mathrm{ft}^{3}$, cubic feet; \%, percent; $\mathrm{ft}^{3} / \mathrm{s}$, cubic foot per second; --, data not available]

\begin{tabular}{|c|c|c|c|c|c|c|c|c|c|c|}
\hline Sample ID & $\begin{array}{c}\text { Start date } \\
\text { (mm/dd/yyyy) }\end{array}$ & $\begin{array}{c}\text { Start } \\
\text { time } \\
(\mathrm{hh:mm})\end{array}$ & $\begin{array}{c}\text { End date } \\
\text { (mm/dd/yyyy) }\end{array}$ & $\begin{array}{l}\text { End time } \\
\text { (hh:mm) }\end{array}$ & $\begin{array}{c}\text { Duration } \\
\text { (hours) }\end{array}$ & $\begin{array}{c}\text { Total event } \\
\text { volume } \\
\left(\mathrm{ft}^{3}\right)\end{array}$ & $\begin{array}{c}\text { Runoff } \\
(\%)\end{array}$ & $\begin{array}{l}\text { Peak } \\
\text { flow } \\
\left(\mathrm{ft}^{\mathrm{t}} / \mathrm{s}\right)\end{array}$ & $\begin{array}{c}\text { Volume } \\
\text { of storm } \\
\text { sampled } \\
(\%)\end{array}$ & $\begin{array}{l}\text { Antecedent } \\
\text { dry time } \\
\text { (days) }\end{array}$ \\
\hline 76 & 09/01/2004 & $05: 17$ & 09/01/2004 & 08:00 & 2.72 & 18,291 & 6 & 9.8 & 95 & 3.39 \\
\hline 77 & $09 / 15 / 2004$ & 09:17 & $09 / 15 / 2004$ & 18:00 & 8.72 & 14,671 & 9 & 2.4 & 97 & 9.05 \\
\hline 78 & $10 / 08 / 2004$ & 00:00 & $10 / 08 / 2004$ & 06:00 & 6.00 & 23,216 & 8 & 8.3 & 97 & 6.04 \\
\hline 79 & $10 / 22 / 2004$ & $17: 00$ & $10 / 23 / 2004$ & 10:00 & 17.00 & 40,435 & 10 & 6.9 & 99 & 3.38 \\
\hline 80 & $11 / 01 / 2004$ & 10:00 & $11 / 02 / 2004$ & 04:00 & 18.00 & 12,882 & 6 & .98 & 94 & 2.25 \\
\hline 81 & $11 / 04 / 2004$ & 01:00 & $11 / 04 / 2004$ & 11:00 & 10.00 & 5,944 & 8 & .81 & 89 & 1.88 \\
\hline 82 & $11 / 26 / 2004$ & 14:00 & $11 / 27 / 2004$ & 19:00 & 29.00 & 19,086 & 10 & 1.3 & 92 & 6.33 \\
\hline 83 & $12 / 05 / 2004$ & 22:00 & $12 / 06 / 2004$ & 10:00 & 12.00 & 13,815 & 9 & 1.3 & 90 & 8.13 \\
\hline 84 & $12 / 07 / 2004$ & 01:00 & $12 / 07 / 2004$ & 14:00 & 13.00 & 32,970 & 13 & 3.7 & 97 & .63 \\
\hline 85 & $04 / 06 / 2005$ & $16: 00$ & 04/07/2005 & 02:00 & 10.00 & 30,750 & 9 & 11 & 97 & 5.75 \\
\hline 86 & $04 / 12 / 2005$ & 00:00 & $04 / 12 / 2005$ & 19:00 & 19.00 & 16,140 & 12 & 4 & 92 & 4.92 \\
\hline 87 & $04 / 19 / 2005$ & 23:00 & $04 / 20 / 2005$ & 02:00 & 3.00 & 5,106 & 8 & 2.7 & 80 & 7.17 \\
\hline 88 & 05/06/2005 & 06:00 & 05/06/2005 & $15: 00$ & 9.00 & 11,336 & 8 & 4.7 & 90 & 10.21 \\
\hline 89 & $05 / 11 / 2005$ & 03:00 & $05 / 11 / 2005$ & 14:00 & 11.00 & 29,134 & 9 & 3.7 & 97 & 4.50 \\
\hline 90 & $05 / 13 / 2005$ & 00:00 & $05 / 13 / 2005$ & 11:00 & 11.00 & 16,969 & 8 & 4.4 & 97 & 1.42 \\
\hline 91 & $05 / 18 / 2005$ & 22:00 & 05/19/2005 & 08:00 & 10.00 & 16,572 & 9 & 2.5 & 93 & 5.46 \\
\hline 92 & $4 / 13 / 2006$ & $21: 31$ & $04 / 14 / 2006$ & $2: 00$ & 4.48 & 4,743 & 7 & 5 & 78 & 1.48 \\
\hline 93 & $4 / 16 / 2006$ & 2:04 & $04 / 16 / 2006$ & 20:00 & 17.93 & 42,932 & 9 & 23 & 98 & 2.00 \\
\hline 94 & 4/29/2006 & $14: 29$ & $04 / 30 / 2006$ & 19:00 & 28.52 & 49,974 & 11 & 3.9 & 89 & 7.44 \\
\hline 95 & 05/01/2006 & $17: 36$ & 05/02/2006 & 0:00 & 6.40 & 12,450 & 8 & 11 & 79 & .94 \\
\hline 96 & 05/09/2006 & $10: 26$ & 05/09/2006 & 19:00 & 8.57 & 12,260 & 8 & 2.3 & 86 & 7.43 \\
\hline 97 & $05 / 17 / 2006$ & $15: 57$ & $05 / 17 / 2006$ & 19:00 & 3.05 & 4,087 & 6 & 1.9 & 92 & .79 \\
\hline 98 & $05 / 24 / 2006$ & $18: 33$ & $05 / 25 / 2006$ & 3:00 & 8.45 & 23,293 & 5 & 26 & 98 & .40 \\
\hline 99 & 05/30/2006 & 13:07 & $05 / 31 / 2006$ & 9:00 & 19.88 & 21,047 & 7 & 19 & 95 & 4.38 \\
\hline 100 & 06/09/2006 & $22: 44$ & 06/10/2006 & 9:00 & 10.27 & 21,833 & 8 & 2.1 & 93 & 3.53 \\
\hline 101 & $06 / 18 / 2006$ & $4: 51$ & $06 / 18 / 2006$ & $17: 00$ & 12.15 & 8,381 & 7 & 5.2 & 90 & 3.62 \\
\hline 102 & $07 / 11 / 2006$ & $7: 31$ & 07/11/2006 & 18:00 & 10.48 & 55,564 & 9 & 6.1 & 96 & 1.40 \\
\hline 103 & 07/20/2006 & $2: 31$ & $07 / 20 / 2006$ & 9:00 & 6.48 & 24,114 & 7 & 10 & 93 & 8.35 \\
\hline 104 & $07 / 27 / 2006$ & $12: 07$ & $07 / 27 / 2006$ & $17: 00$ & 4.88 & 33,333 & 8 & 18 & 97 & 1.38 \\
\hline 105 & 08/06/2006 & $5: 49$ & 08/06/2006 & 13:00 & 7.18 & 19,025 & 7 & 2.9 & 93 & 9.53 \\
\hline 106 & 08/17/2006 & $12: 30$ & 08/17/2006 & 20:00 & 7.50 & 8,087 & 6 & 5.7 & 91 & 10.98 \\
\hline 107 & $08 / 23 / 2006$ & $22: 25$ & $08 / 24 / 2006$ & 6:00 & 7.58 & 64,990 & 8 & 27 & 76 & 6.10 \\
\hline 108 & $08 / 24 / 2006$ & $13: 19$ & $08 / 24 / 2006$ & 18:00 & 4.68 & 40,280 & 10 & 28 & 99 & .14 \\
\hline 109 & $08 / 25 / 2006$ & $6: 10$ & $08 / 25 / 2006$ & 13:00 & 6.83 & 26,179 & 10 & 6.6 & 92 & .51 \\
\hline 110 & $09 / 03 / 2006$ & 19:04 & 09/04/2006 & 10:00 & 14.93 & 20,399 & 8 & 3.2 & 95 & 6.04 \\
\hline 111 & 09/10/2006 & $8: 32$ & $09 / 13 / 2006$ & 0:00 & 63.47 & 103,766 & 30 & 13 & 98 & 5.94 \\
\hline
\end{tabular}




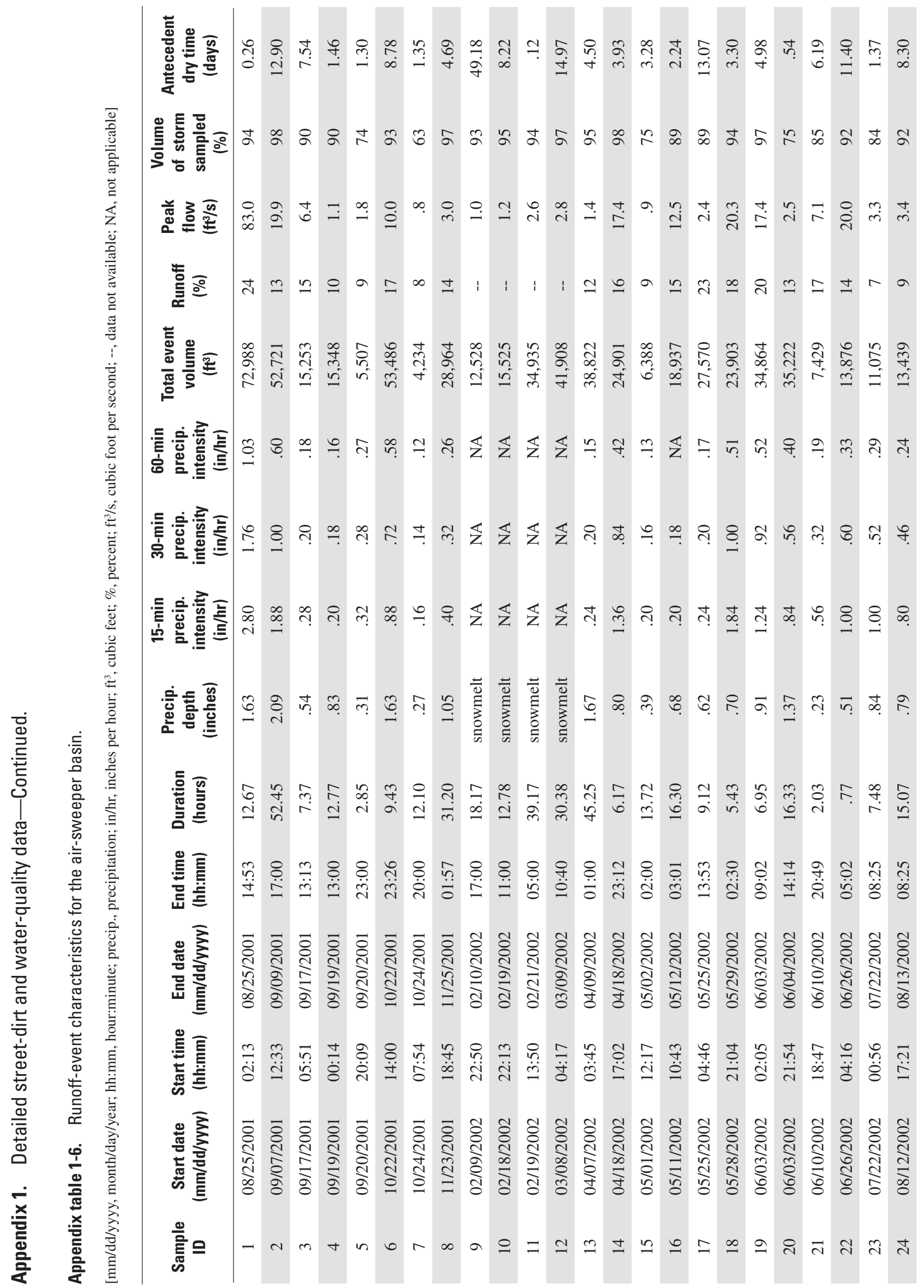




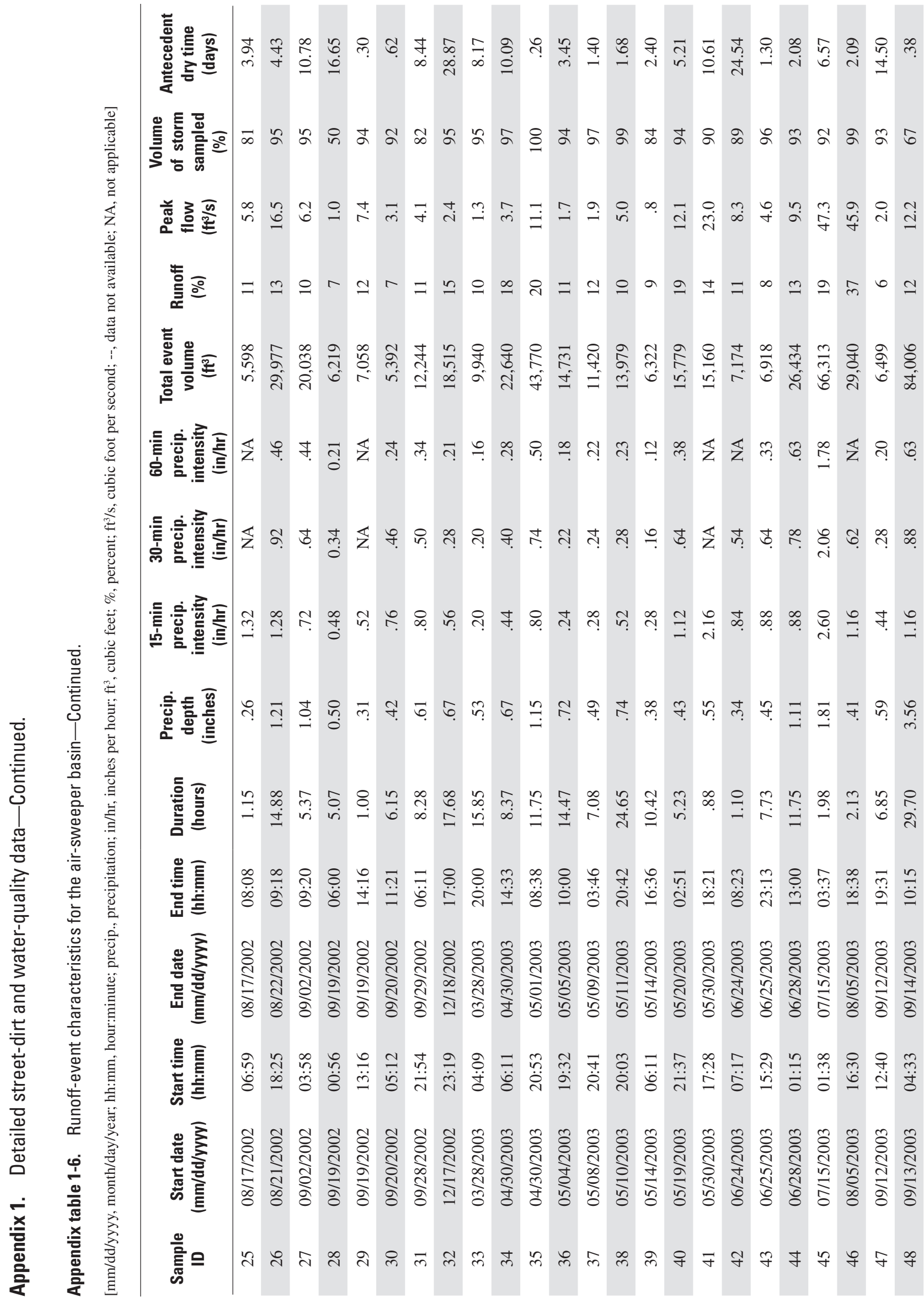




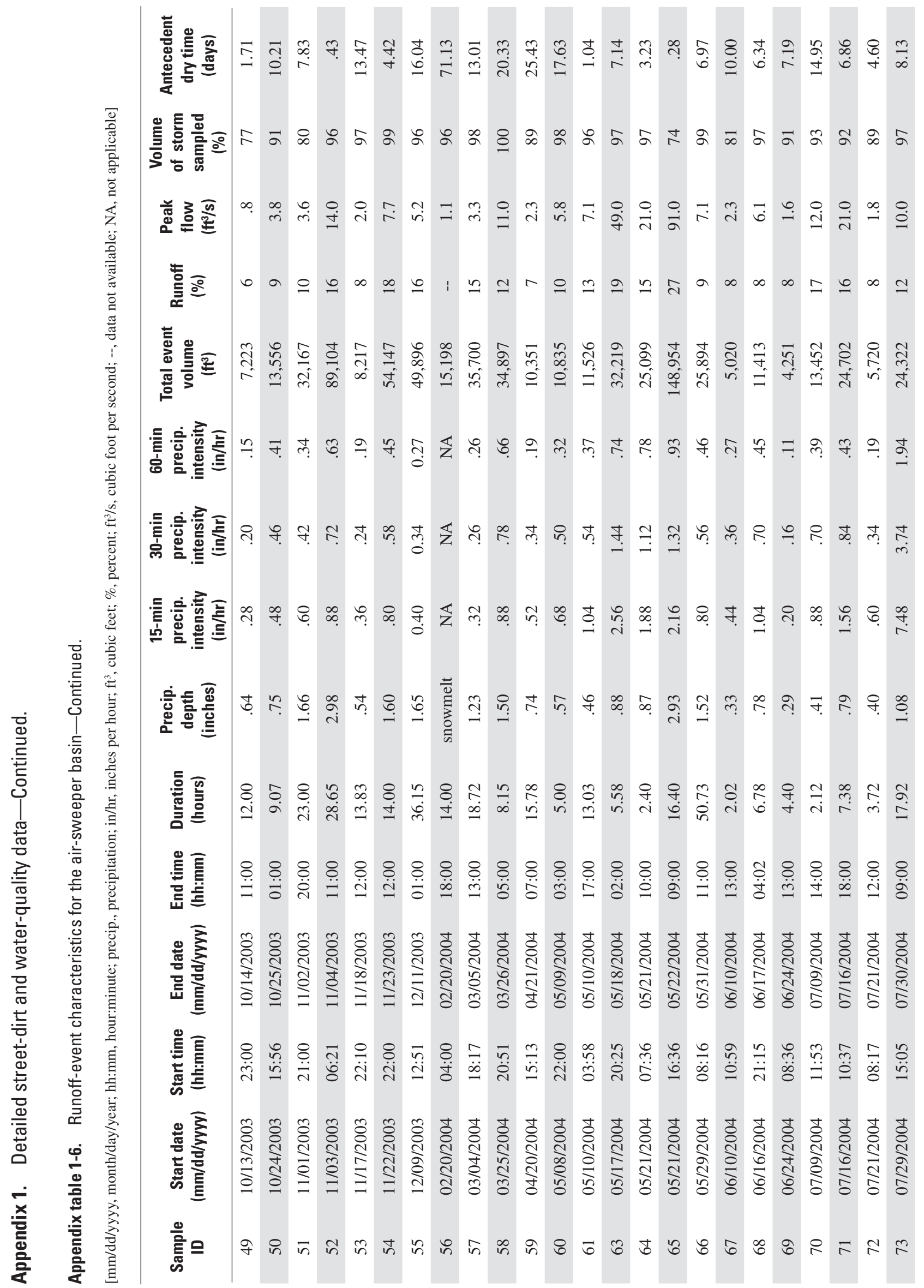




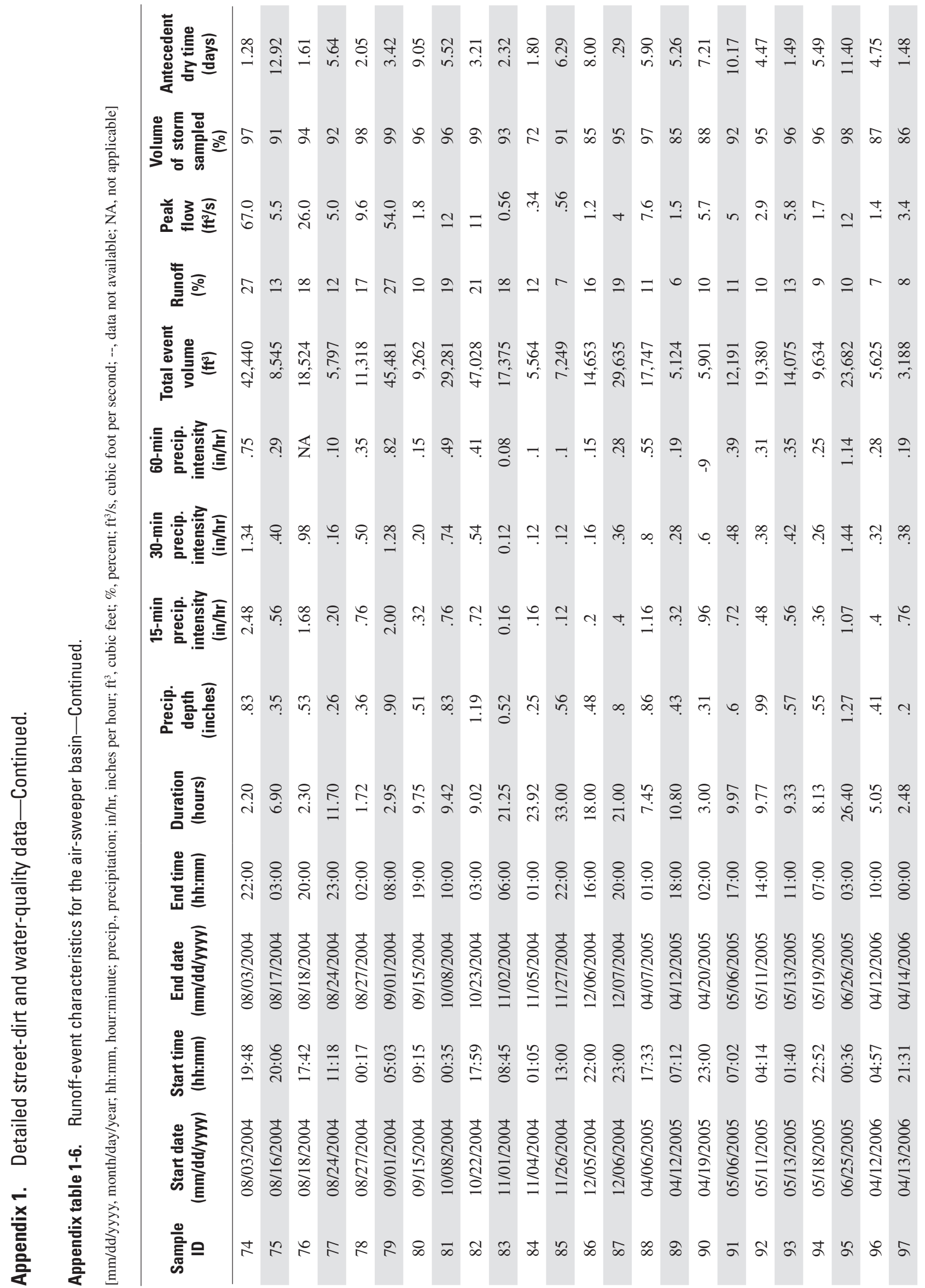




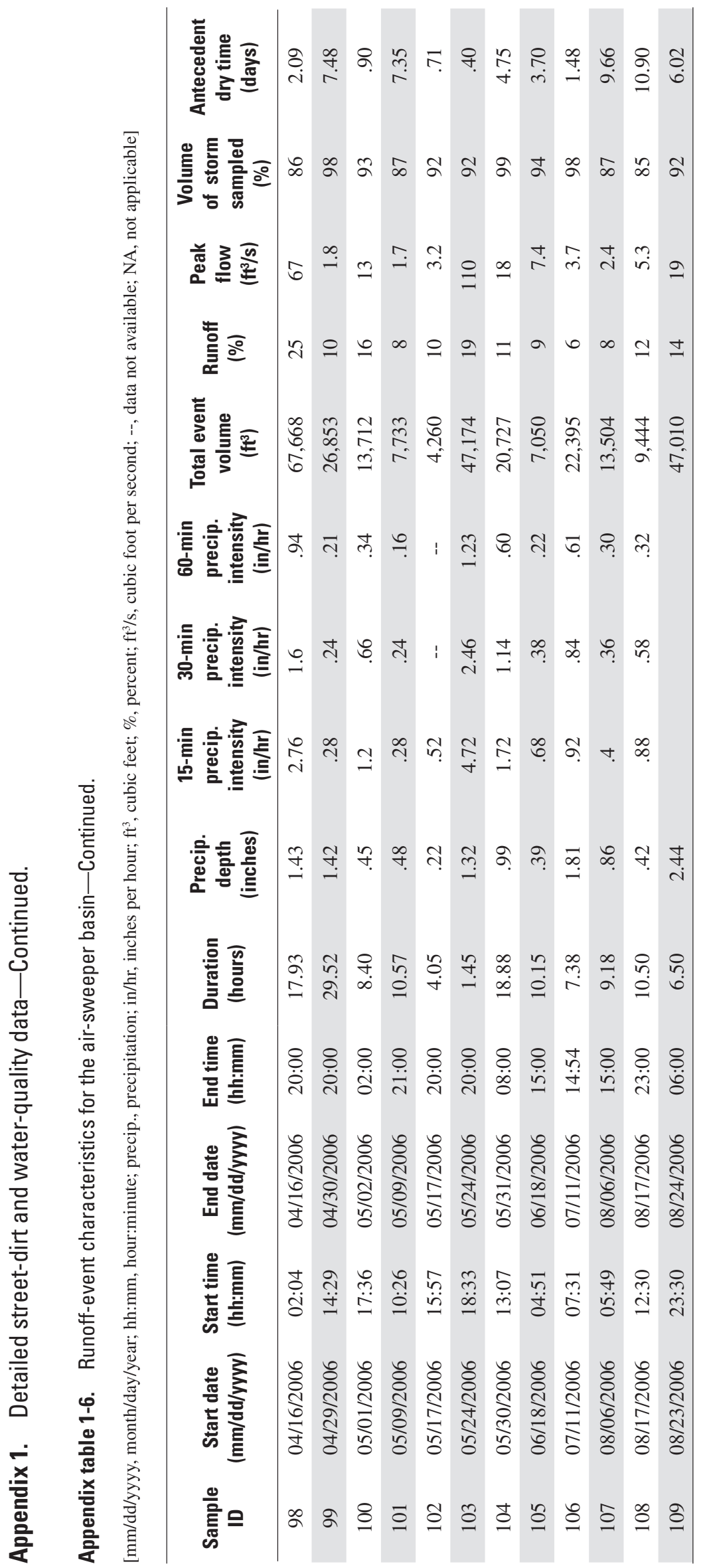




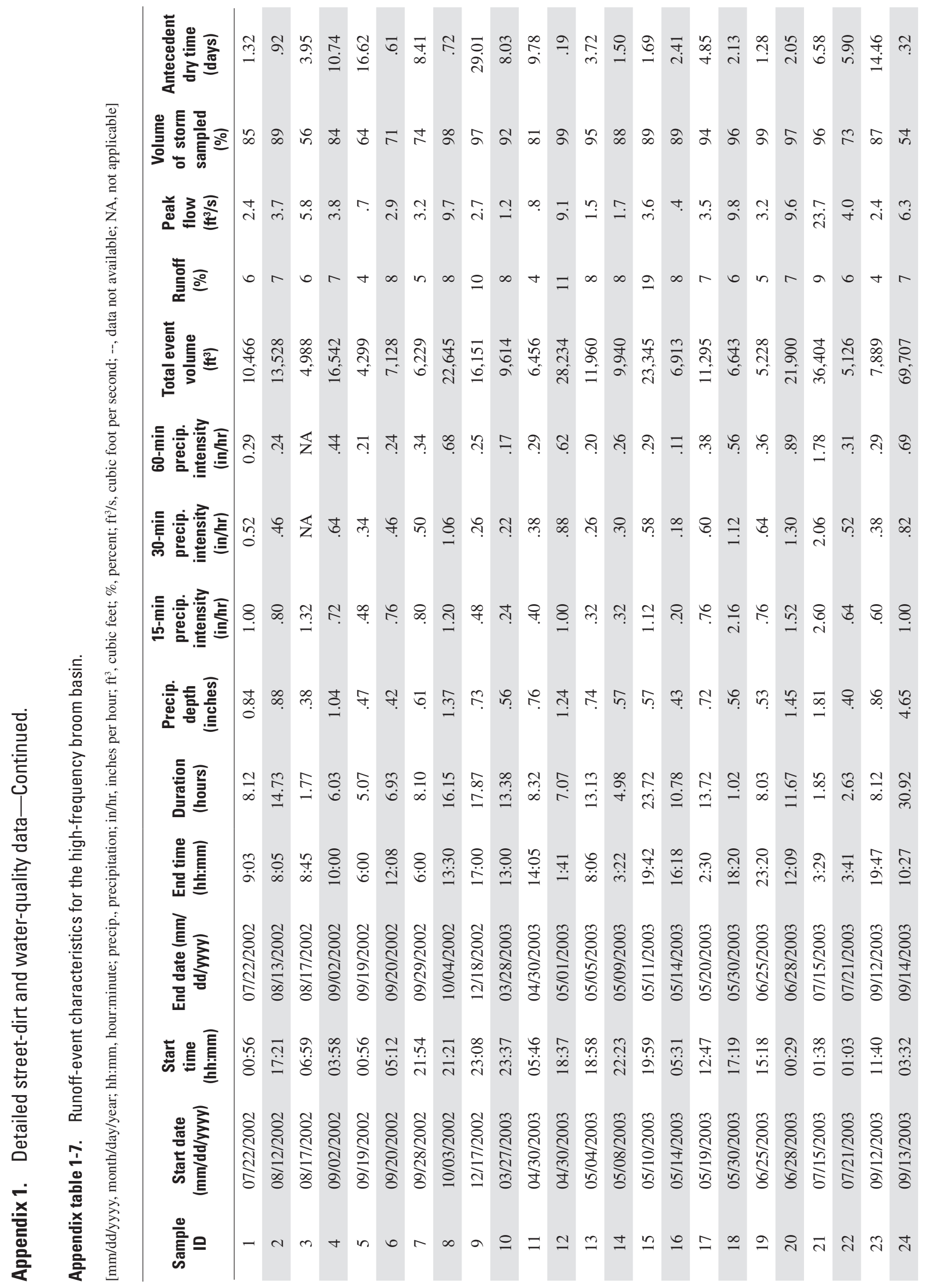




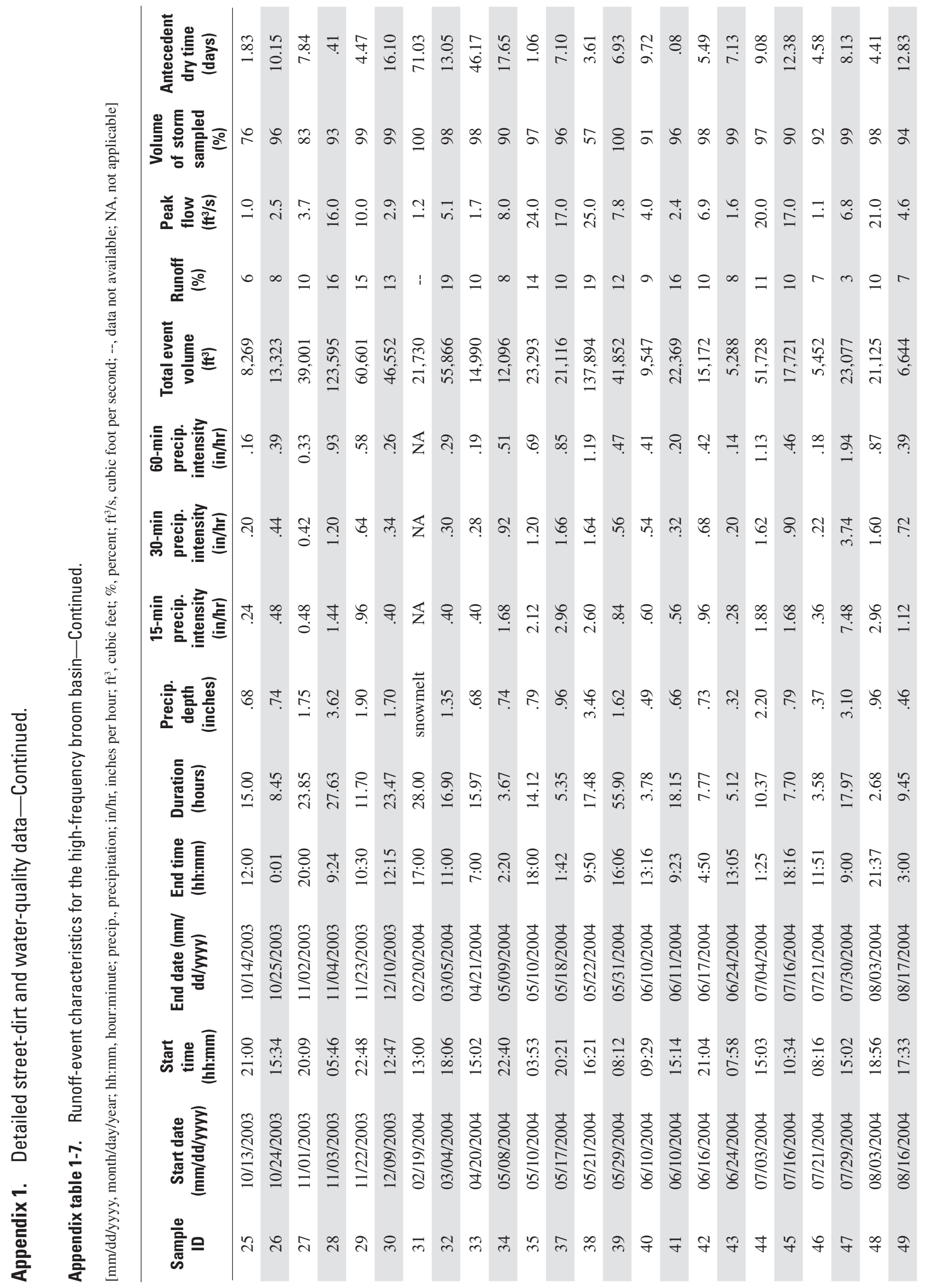




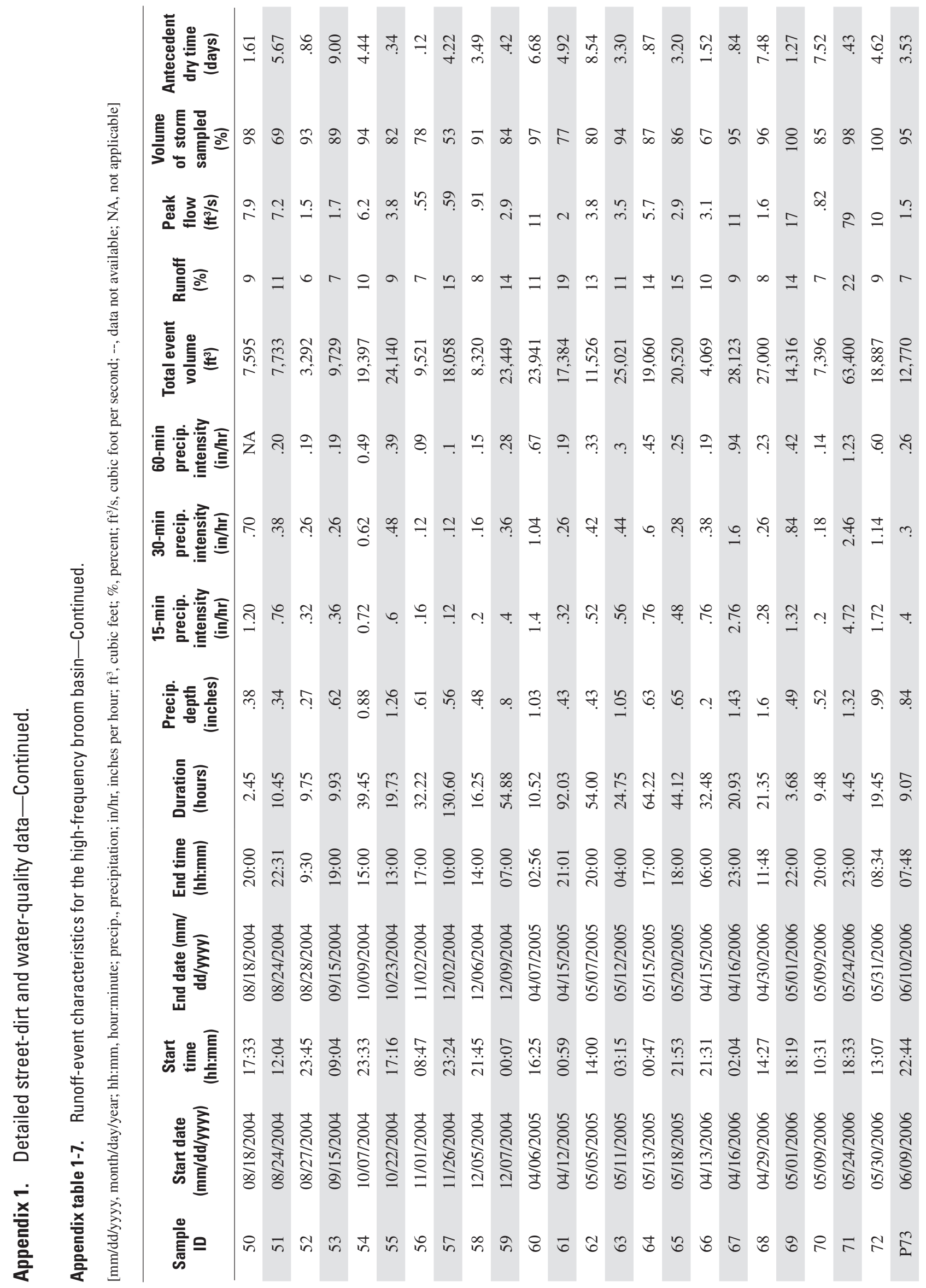




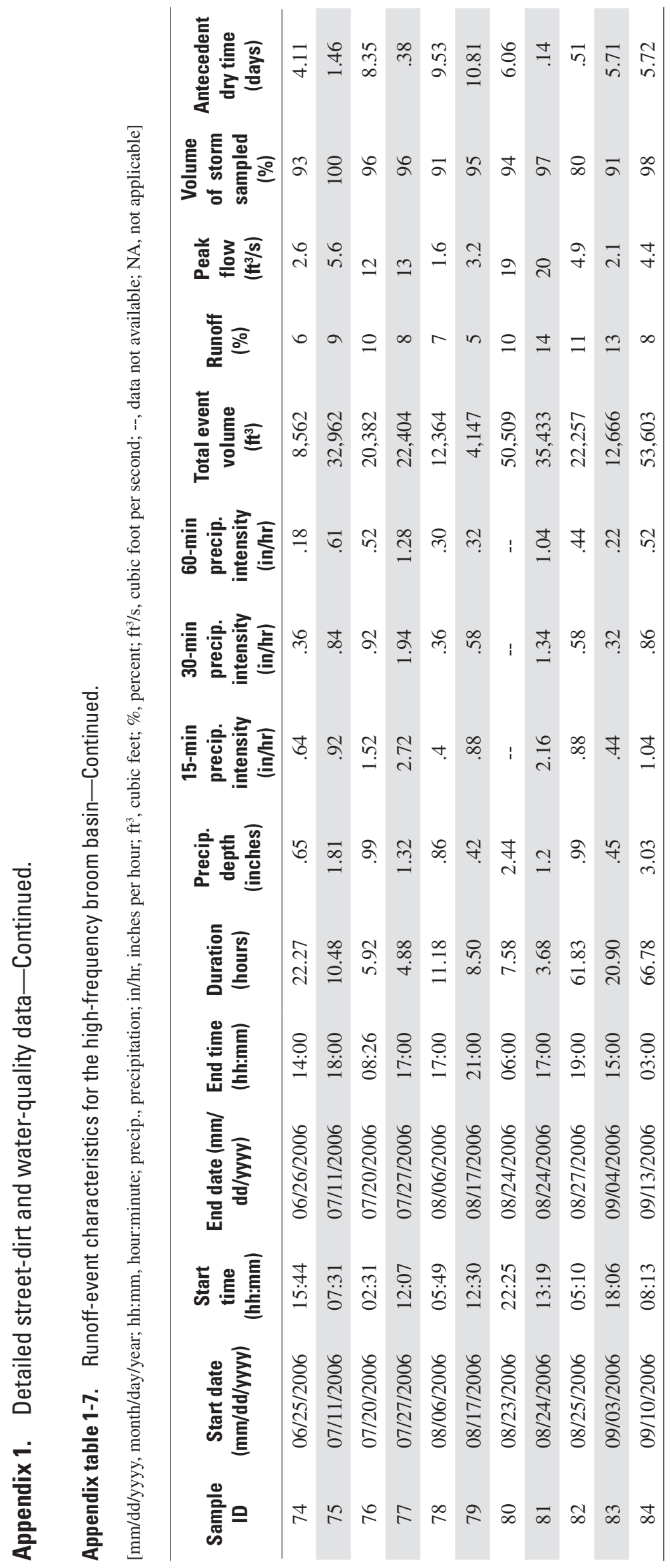


Appendix 1. Detailed street-dirt and water-quality data-Continued.

Appendix table 1-8a. Constituent event mean concentrations measured at the control and air-sweeper basin outlets during the calibration phase.

[ug/L, microgram per liter; mg/L, milligram per liter; <, less than; --, no data]

\begin{tabular}{|c|c|c|c|c|c|c|c|c|c|c|}
\hline \multirow[b]{2}{*}{ Event date } & \multicolumn{2}{|c|}{$\begin{array}{c}\text { Cadmium, } \\
\text { total recoverable } \\
(\mu \mathrm{g} / \mathrm{L})\end{array}$} & \multicolumn{2}{|c|}{$\begin{array}{c}\text { Calcium, } \\
\text { total recoverable } \\
(\mathrm{mg} / \mathrm{L})\end{array}$} & \multicolumn{2}{|c|}{$\begin{array}{l}\text { Copper, } \\
\text { dissolved } \\
(\mu \mathrm{g} / \mathrm{L})\end{array}$} & \multicolumn{2}{|c|}{$\begin{array}{c}\text { Copper, } \\
\text { total recoverable } \\
(\mu \mathrm{g} / \mathrm{L})\end{array}$} & \multicolumn{2}{|c|}{$\begin{array}{c}\text { Lead, } \\
\text { total recoverable } \\
(\mu \mathrm{g} / \mathrm{L})\end{array}$} \\
\hline & Control & Air & Control & Air & Control & Air & Control & Air & Control & Air \\
\hline 09/07/2001 & 0.18 & 0.16 & 12.9 & 32.1 & $<0.9$ & 2 & 4.5 & 11.0 & 4.9 & 15.0 \\
\hline 09/17/2001 & $<0.20$ & $<0.20$ & 31.0 & 44.0 & 3.1 & 2.2 & 8.9 & 14.0 & 2.9 & 13.0 \\
\hline 09/19/2001 & $<0.20$ & $<0.20$ & 6.0 & 5.7 & 3 & $<1.46$ & 2.6 & 3.9 & 3.2 & 3.5 \\
\hline 04/07/2002 & $<0.20$ & .20 & 14.1 & 10.3 & 2 & 2.5 & 9.1 & 12.0 & 4.6 & 7.8 \\
\hline $04 / 18 / 2002$ & 59.90 & .62 & 59.9 & 91.8 & 2.8 & 3.2 & 28.0 & 41.0 & 22.0 & 44.0 \\
\hline $05 / 11 / 2002$ & .28 & .65 & 42.7 & 98.5 & 3.8 & 3 & 26.0 & 33.0 & 15.0 & 30.0 \\
\hline $05 / 25 / 2002$ & .26 & $<0.20$ & 14.1 & 10.8 & 4.4 & 3 & 14.0 & 14.0 & 2.7 & 4.3 \\
\hline $05 / 28 / 2002$ & .38 & .61 & 36.1 & 154.0 & 4.2 & 5.9 & 23.0 & 40.0 & 14.0 & 29.0 \\
\hline 06/02/2002 & .37 & .40 & 94.1 & 67.0 & 6.1 & 4.6 & 18.0 & 30.0 & 16.0 & 22.0 \\
\hline $06 / 10 / 2002$ & .31 & 1.43 & 32.7 & 71.8 & 4.8 & 2.5 & 21.0 & 27.0 & 12.0 & 26.0 \\
\hline $06 / 26 / 2002$ & .50 & .61 & 23.0 & 103.0 & 4.1 & 4.4 & 13.0 & 26.0 & 13.0 & 130.0 \\
\hline $07 / 22 / 2002$ & .37 & .39 & 24.6 & 18.3 & 4.8 & 7 & 16.0 & 12.0 & 10.0 & 145.0 \\
\hline $08 / 17 / 2002$ & .49 & .56 & 32.0 & 60.0 & 4.4 & 5 & 19.0 & 18.0 & 10.0 & 14.0 \\
\hline $08 / 21 / 2002$ & .27 & .36 & 16.0 & 67.0 & 2.3 & 3.2 & 10.0 & 15.0 & 7.5 & 16.0 \\
\hline 09/02/2002 & $<0.20$ & $<0.20$ & 13.5 & 13.0 & 2.6 & 2 & 11.0 & 8.1 & 5.0 & 12.0 \\
\hline 09/19/2002 & $<0.20$ & .36 & 98.0 & 54.3 & 1.9 & 2 & 15.0 & 21.0 & 12.0 & 22.0 \\
\hline $09 / 20 / 2002$ & $<0.17$ & $<0.17$ & 5.5 & 10.2 & 6.9 & 3.5 & 14.0 & 9.1 & 3.4 & 20.0 \\
\hline 04/16/2006 & .30 & .80 & 34.5 & 101.6 & $<1.2$ & $<1.2$ & 17.5 & 39.6 & 17.2 & 41.1 \\
\hline 04/29/2006 & 5.10 & .24 & 22.0 & 13.0 & 1.4 & 2.4 & 26.0 & 12.0 & 12.0 & 2.3 \\
\hline 05/09/2006 & $<0.20$ & $<0.20$ & 29.0 & 8.9 & 2.3 & 2.1 & 20.0 & 16.0 & 3.9 & $<1.47$ \\
\hline 05/17/2006 & .30 & $<0.20$ & 13.0 & 24.0 & $<1.2$ & $<1.2$ & 12.0 & 16.0 & 2.1 & 8.7 \\
\hline 05/24/2006 & .12 & 1.20 & 23.2 & 172.1 & 2 & $<1.2$ & 23.9 & 67.5 & 14.1 & 63.8 \\
\hline 05/30/2006 & .04 & .34 & 17.8 & 94.5 & 3.6 & 1.9 & 17.9 & 30.2 & 7.6 & 36.4 \\
\hline 06/10/2006 & $<0.20$ & -- & 5.4 & -- & 2.6 & -- & 6.3 & -- & $<1.47$ & -- \\
\hline 06/18/2006 & .27 & .23 & 12.0 & 61.0 & 2.1 & 1.2 & 11.0 & 32.0 & 5.0 & 18.0 \\
\hline 07/11/2006 & .03 & .05 & 6.9 & 7.4 & $<1.2$ & 1.2 & 6.8 & 9.9 & 1.0 & 4.7 \\
\hline 07/20/2006 & $<0.20$ & -- & 14.0 & -- & 1.9 & -- & 11.0 & -- & 4.9 & -- \\
\hline 07/27/2006 & $<0.20$ & -- & 9.0 & -- & $<1.2$ & -- & 7.2 & -- & 5.5 & -- \\
\hline 08/06/2006 & $<0.20$ & $<0.20$ & 6.7 & 14.0 & 1.4 & 1.9 & 6.1 & 7.2 & 1.9 & 4.0 \\
\hline 08/17/2006 & $<0.20$ & $<0.20$ & 16.0 & 16.0 & 3.2 & 2.2 & 15.0 & 14.0 & 6.2 & 6.7 \\
\hline 08/24/2006 & $<0.20$ & -- & 9.8 & -- & $<1.2$ & -- & 6.7 & -- & 4.6 & -- \\
\hline 08/25/2006 & $<0.20$ & -- & 6.0 & -- & $<1.2$ & -- & 4.2 & -- & 3.4 & -- \\
\hline 09/03/2006 & $<0.20$ & -- & 6.9 & -- & 1.8 & -- & 4.0 & -- & $<1.47$ & -- \\
\hline 09/10/2006 & $<0.20$ & -- & 24.0 & -- & 1.5 & -- & 7.1 & -- & 4.8 & -- \\
\hline
\end{tabular}


Appendix 1. Detailed street-dirt and water-quality data-Continued.

Appendix table 1-8a. Constituent event mean concentrations measured the control and air-sweeper basin outlets during the calibration phase-Continued.

[ $\mu \mathrm{g} / \mathrm{L}$, microgram per liter; $\mathrm{mg} / \mathrm{L}$, milligram per liter; <, less than; --, no data]

\begin{tabular}{|c|c|c|c|c|c|c|c|c|c|c|}
\hline \multirow[b]{2}{*}{ Event date } & \multicolumn{2}{|c|}{$\begin{array}{c}\text { Magnesium, } \\
\text { total recoverable } \\
(\mathrm{mg} / \mathrm{L})\end{array}$} & \multicolumn{2}{|c|}{$\begin{array}{c}\text { Phosphorus, } \\
\text { total recoverable } \\
(\mathrm{mg} / \mathrm{L})\end{array}$} & \multicolumn{2}{|c|}{$\begin{array}{l}\text { Orthophosphorus, } \\
\text { dissolved } \\
\text { (mg/L) }\end{array}$} & \multicolumn{2}{|c|}{$\begin{array}{c}\text { Zinc, } \\
\text { dissolved } \\
(\mu \mathrm{g} / \mathrm{L})\end{array}$} & \multicolumn{2}{|c|}{$\begin{array}{c}\text { Zinc, } \\
\text { total recoverable } \\
(\mu \mathrm{g} / \mathrm{L})\end{array}$} \\
\hline & Control & Air & Control & Air & Control & Air & Control & Air & Control & Air \\
\hline 09/07/2001 & 6.4 & 16.6 & 0.30 & 0.45 & 0.13 & 0.14 & 4.6 & 7.4 & 28.0 & 54.0 \\
\hline 09/17/2001 & 17.0 & 25.0 & .28 & .47 & .13 & .13 & 4.4 & 2.4 & 27.0 & 56.0 \\
\hline 09/19/2001 & 2.4 & 2.3 & .19 & .24 & .12 & .14 & 8.6 & 8.7 & 11.0 & 17.0 \\
\hline 04/07/2002 & 6.2 & 4.3 & .15 & .19 & $<0.05$ & .05 & 2.8 & 7.6 & 29.0 & 53.0 \\
\hline $04 / 18 / 2002$ & 30.8 & 48.8 & .64 & 1.01 & .11 & .10 & 5.9 & 5 & 97.0 & 191.0 \\
\hline $05 / 11 / 2002$ & 18.8 & 49.4 & .69 & 1.27 & .10 & .12 & 7.6 & 4.6 & 65.0 & 203.0 \\
\hline $05 / 25 / 2002$ & 5.5 & 3.5 & .90 & 1.42 & .25 & .50 & 11 & 11 & 43.0 & 63.0 \\
\hline $05 / 28 / 2002$ & 18.2 & 78.1 & .67 & 1.19 & .19 & .32 & 9.7 & 18 & 100.0 & 194.0 \\
\hline 06/02/2002 & 45.5 & 31.3 & .72 & .68 & .18 & .15 & 15 & 6.7 & 56.0 & 98.0 \\
\hline 06/10/2002 & 15.3 & 32.9 & 1.17 & 2.20 & .64 & .87 & 12 & 28 & 82.0 & 297.0 \\
\hline $06 / 26 / 2002$ & 11.1 & 47.5 & .84 & 1.08 & .43 & .44 & 16 & 15 & 70.0 & 431.0 \\
\hline $07 / 22 / 2002$ & 11.1 & 7.8 & .58 & .57 & .20 & .35 & 10 & 22 & 66.0 & 67.0 \\
\hline 08/17/2002 & 16.0 & 23.0 & .50 & .62 & .14 & .19 & 8.1 & 12 & 73.0 & 102.0 \\
\hline $08 / 21 / 2002$ & 7.1 & 34.0 & .29 & .54 & .08 & .15 & 3.6 & 6.4 & 40.0 & 81.0 \\
\hline 09/02/2002 & 6.0 & 5.8 & .40 & .33 & .20 & .17 & 6.4 & 5.9 & 34.0 & 36.0 \\
\hline 09/19/2002 & 52.8 & 26.3 & .51 & .80 & .12 & .15 & 4.1 & 5.1 & 69.0 & 106.0 \\
\hline 09/20/2002 & 2.4 & 4.8 & .25 & .33 & .10 & .15 & 8.4 & 8.4 & 23.0 & 40.0 \\
\hline $04 / 16 / 2006$ & 18.6 & 53.3 & .53 & 1.09 & .06 & .06 & 1.2 & 1.7 & 83.4 & 205.2 \\
\hline $04 / 29 / 2006$ & 9.1 & 4.6 & 11.00 & .64 & .13 & .18 & 9 & 28 & 658.0 & 64.0 \\
\hline 05/09/2006 & 8.9 & 2.9 & 3.57 & .75 & .42 & .16 & 21 & 7.7 & 92.0 & 56.0 \\
\hline 05/17/2006 & 4.8 & 9.9 & .88 & 1.21 & .29 & .25 & 7.4 & 6.5 & 49.0 & 90.0 \\
\hline $05 / 24 / 2006$ & 11.7 & 91.9 & .80 & 2.74 & .12 & .20 & 1.2 & 2.4 & 65.5 & 331.1 \\
\hline 05/30/2006 & 8.6 & 54.3 & .66 & 1.36 & .29 & .26 & 3.4 & 3.1 & 40.3 & 153.2 \\
\hline 06/10/2006 & 2.0 & -- & .65 & -- & .29 & -- & 1.8 & -- & 24.0 & -- \\
\hline 06/18/2006 & 5.0 & 30.0 & .64 & .83 & .22 & .14 & 7.6 & 4.4 & 43.0 & 184.0 \\
\hline 07/11/2006 & 2.8 & 3.2 & .27 & .33 & .09 & .10 & 1.9 & 2.8 & 27.2 & 41.4 \\
\hline $07 / 20 / 2006$ & 6.1 & -- & .48 & -- & .15 & -- & 4.5 & -- & 42.0 & -- \\
\hline $07 / 27 / 2006$ & 4.3 & -- & .29 & -- & .09 & -- & 3.6 & -- & 35.0 & -- \\
\hline 08/06/2006 & 2.3 & 6.3 & .39 & .55 & .25 & .36 & 3.6 & 5.8 & 22.0 & 28.0 \\
\hline 08/17/2006 & 5.6 & 6.7 & .76 & .77 & .32 & .41 & 8 & 7.9 & 66.0 & 75.0 \\
\hline 08/24/2006 & 4.4 & -- & .28 & -- & .10 & -- & 2.4 & -- & 24.0 & -- \\
\hline $08 / 25 / 2006$ & 2.4 & -- & .18 & -- & .07 & -- & 2.5 & -- & 16.0 & -- \\
\hline 09/03/2006 & 2.8 & -- & .32 & -- & .20 & -- & 6 & -- & 17.0 & -- \\
\hline 09/10/2006 & 12.0 & -- & .23 & -- & .09 & -- & 2.6 & -- & 24.0 & -- \\
\hline
\end{tabular}


Appendix 1. Detailed street-dirt and water-quality data-Continued.

Appendix table 1-8a. Constituent event mean concentrations measured at the control and air-sweeper basin outlets during the calibration phase-Continued.

[ $\mu \mathrm{g} / \mathrm{L}$, microgram per liter; mg/L, milligram per liter; <, less than; --, no data]

\begin{tabular}{|c|c|c|c|c|c|c|c|c|}
\hline \multirow[b]{2}{*}{ Event date } & \multicolumn{2}{|c|}{$\begin{array}{c}\text { Ammonia-nitrogen } \\
\text { (mg/L) }\end{array}$} & \multicolumn{2}{|c|}{$\begin{array}{l}\text { Nitrate plus nitrite, } \\
\text { dissolved } \\
(\mathrm{mg} / \mathrm{L})\end{array}$} & \multicolumn{2}{|c|}{$\begin{array}{c}\text { Dissolved solids, } \\
\text { total } \\
\text { (mg/L) }\end{array}$} & \multicolumn{2}{|c|}{$\begin{array}{c}\text { Suspended sediment, } \\
\text { total } \\
(\mathrm{mg} / \mathrm{L})\end{array}$} \\
\hline & Control & Air & Control & Air & Control & Air & Control & Air \\
\hline 09/07/2001 & 0.19 & 0.19 & 0.42 & 0.29 & 0.42 & 0.29 & 230 & 956 \\
\hline 09/17/2001 & $<0.05$ & .06 & .67 & .52 & .67 & .52 & 161 & 410 \\
\hline 09/19/2001 & .18 & .18 & .58 & .57 & .58 & .57 & 39 & 48 \\
\hline $04 / 07 / 2002$ & .30 & .32 & .27 & .28 & .27 & .28 & 227 & 107 \\
\hline $04 / 18 / 2002$ & .76 & .68 & .40 & .40 & .40 & .40 & 1,241 & 2,535 \\
\hline $05 / 11 / 2002$ & .38 & .34 & .35 & .19 & .35 & .19 & 853 & 2,657 \\
\hline 05/25/2002 & .58 & .54 & .37 & .39 & .37 & .39 & 428 & 180 \\
\hline $05 / 28 / 2002$ & .91 & .87 & 1.01 & 1.01 & 1.01 & 1.01 & 851 & 4,470 \\
\hline 06/02/2002 & .57 & .50 & .49 & .42 & .49 & .42 & 3,394 & 1,966 \\
\hline 06/10/2002 & .73 & .92 & .61 & .75 & .61 & .75 & 688 & 1,333 \\
\hline 06/26/2002 & .76 & .65 & .85 & .90 & .85 & .90 & 450 & 3,047 \\
\hline $07 / 22 / 2002$ & .56 & .38 & .46 & .60 & .46 & .60 & 932 & 429 \\
\hline 08/17/2002 & .47 & .49 & .76 & .74 & .76 & .74 & 611 & 1,123 \\
\hline $08 / 21 / 2002$ & .23 & .25 & .29 & .34 & .29 & .34 & 440 & 1,536 \\
\hline 09/02/2002 & .61 & .52 & .67 & .52 & .67 & .52 & 440 & 500 \\
\hline $09 / 19 / 2002$ & .25 & .34 & .32 & .32 & .32 & .32 & 1,324 & 1,088 \\
\hline 09/20/2002 & .20 & .23 & .24 & .23 & .24 & .23 & 57 & 205 \\
\hline $04 / 16 / 2006$ & .32 & .36 & .27 & .28 & .27 & .28 & 602 & 1,938 \\
\hline $04 / 29 / 2006$ & .56 & .65 & .44 & .54 & .44 & .54 & 113 & 125 \\
\hline 05/09/2006 & .55 & .66 & .39 & .28 & .39 & .28 & 392 & 140 \\
\hline 05/17/2006 & .55 & .35 & .38 & .32 & .38 & .32 & 203 & 479 \\
\hline $05 / 24 / 2006$ & .77 & 1.00 & .42 & .42 & .42 & .42 & 555 & 4,166 \\
\hline 05/30/2006 & .65 & .70 & .49 & .48 & .49 & .48 & 253 & 1,782 \\
\hline 06/10/2006 & .23 & -- & .26 & -- & .26 & -- & 51 & -- \\
\hline 06/18/2006 & .52 & .35 & .58 & .35 & .58 & .35 & 183 & 243 \\
\hline $07 / 11 / 2006$ & .06 & .04 & $<.18$ & $<.18$ & $<.18$ & $<.18$ & 119 & 171 \\
\hline 07/20/2006 & .49 & -- & .53 & -- & .53 & -- & 191 & -- \\
\hline $07 / 27 / 2006$ & .60 & -- & .33 & -- & .33 & -- & 150 & -- \\
\hline 08/06/2006 & .30 & .22 & .42 & .38 & .42 & .38 & 65 & 149 \\
\hline 08/17/2006 & .51 & .41 & .76 & .73 & .76 & .73 & 238 & 285 \\
\hline $08 / 24 / 2006$ & .56 & -- & .43 & -- & .43 & -- & 173 & -- \\
\hline $08 / 25 / 2006$ & .48 & -- & .52 & -- & .52 & -- & 95 & -- \\
\hline 09/03/2006 & .15 & -- & .31 & -- & .31 & -- & 63 & -- \\
\hline 09/10/2006 & .18 & -- & .59 & -- & .59 & -- & 135 & -- \\
\hline
\end{tabular}


Appendix 1. Detailed street-dirt and water-quality data-Continued.

Appendix table 1-8b. Constituent event mean concentrations measured the control and high-frequency broom basin outlets during the calibration phase.

[ $\mu \mathrm{g} / \mathrm{L}$, microgram per liter; mg/L, milligram per liter; <, less than; --, no data]

\begin{tabular}{|c|c|c|c|c|c|c|c|c|c|c|}
\hline \multirow[b]{2}{*}{ Event date } & \multicolumn{2}{|c|}{$\begin{array}{c}\text { Cadmium, } \\
\text { total recoverable } \\
(\mu \mathrm{g} / \mathrm{L})\end{array}$} & \multicolumn{2}{|c|}{$\begin{array}{c}\text { Calcium, } \\
\text { total recoverable } \\
(\mathrm{mg} / \mathrm{L})\end{array}$} & \multicolumn{2}{|c|}{$\begin{array}{l}\text { Copper, } \\
\text { dissolved } \\
(\mu \mathrm{g} / \mathrm{L})\end{array}$} & \multicolumn{2}{|c|}{$\begin{array}{c}\text { Copper, } \\
\text { total recoverable } \\
(\mu \mathrm{g} / \mathrm{L})\end{array}$} & \multicolumn{2}{|c|}{$\begin{array}{c}\text { Lead, } \\
\text { total recoverable } \\
(\mu \mathrm{g} / \mathrm{L})\end{array}$} \\
\hline & Control & Broom & Control & Broom & Control & Broom & Control & Broom & Control & Broom \\
\hline 09/07/2001 & 0.18 & -- & 12.9 & -- & $<0.9$ & -- & 4.5 & -- & 4.9 & -- \\
\hline 09/17/2001 & $<0.20$ & -- & 31.0 & -- & 3.1 & -- & 8.9 & -- & 2.9 & -- \\
\hline 09/19/2001 & $<0.20$ & -- & 6.0 & -- & 3 & -- & 2.6 & -- & 3.2 & -- \\
\hline 04/07/2002 & $<0.20$ & -- & 14.1 & -- & 2 & -- & 9.1 & -- & 4.6 & -- \\
\hline $04 / 18 / 2002$ & 59.90 & -- & 59.9 & -- & 2.8 & -- & 28.0 & -- & 22.0 & -- \\
\hline 05/11/2002 & .28 & -- & 42.7 & -- & 3.8 & -- & 26.0 & -- & 15.0 & -- \\
\hline $05 / 25 / 2002$ & .26 & -- & 14.1 & -- & 4.4 & -- & 14.0 & -- & 2.7 & -- \\
\hline $05 / 28 / 2002$ & .38 & -- & 36.1 & -- & 4.2 & -- & 23.0 & -- & 14.0 & -- \\
\hline 06/02/2002 & .37 & -- & 94.1 & -- & 6.1 & -- & 18.0 & -- & 16.0 & -- \\
\hline 06/10/2002 & .31 & -- & 32.7 & -- & 4.8 & -- & 21.0 & -- & 12.0 & -- \\
\hline 06/26/2002 & .50 & -- & 23.0 & -- & 4.1 & -- & 13.0 & -- & 13.0 & -- \\
\hline $07 / 22 / 2002$ & .37 & 0.50 & 24.6 & 19.7 & 4.8 & 15 & 16.0 & 21.0 & 10.0 & 5.3 \\
\hline 08/17/2002 & .49 & -- & 32.0 & -- & 4.4 & -- & 19.0 & -- & 10.0 & -- \\
\hline 08/21/2002 & .27 & -- & 16.0 & -- & 2.3 & -- & 10.0 & -- & 7.5 & -- \\
\hline 09/02/2002 & $<0.20$ & $<0.2$ & 13.5 & 8.4 & 2.6 & 1.7 & 11.0 & 5.4 & 5.0 & 3.3 \\
\hline 09/19/2002 & $<0.20$ & -- & 98.0 & -- & 1.9 & -- & 15.0 & -- & 12.0 & -- \\
\hline 09/20/2002 & $<0.17$ & -- & 5.5 & -- & 6.9 & -- & 14.0 & -- & 3.4 & -- \\
\hline 04/06/2005 & .24 & $<0.23$ & 48.7 & 75.6 & 2.5 & 1.8 & 22.1 & 28.1 & 22.3 & 19.3 \\
\hline $04 / 12 / 2005$ & $<0.23$ & $<0.23$ & 12.0 & 15.3 & $<1.34$ & 2.2 & 11.0 & 13.2 & 5.4 & 6.1 \\
\hline 04/19/2005 & $<0.23$ & -- & 46.0 & -- & 3.9 & -- & 32.0 & -- & 22.0 & -- \\
\hline 05/06/2005 & .37 & .23 & 37.2 & 35.5 & 3.8 & 4.2 & 34.8 & 36.2 & 19.4 & 17.4 \\
\hline 05/11/2005 & $<0.23$ & $<0.23$ & 12.1 & 15.0 & 2.9 & 2.6 & 9.0 & 17.2 & 6.5 & 7.8 \\
\hline 05/13/2005 & $<0.23$ & $<0.23$ & 11.1 & 60.1 & $<1.34$ & $<1.34$ & 6.5 & 19.2 & 8.1 & 40.3 \\
\hline 05/18/2005 & .25 & .23 & 13.1 & 14.7 & 1.4 & 2.4 & 9.8 & 10.4 & 9.5 & 5.9 \\
\hline 04/16/2006 & .30 & .23 & 34.5 & 36.2 & $<1.2$ & $<1.2$ & 17.5 & 23.5 & 17.2 & 20.4 \\
\hline 04/29/2006 & 5.10 & $<0.20$ & 22.0 & 11.0 & 1.4 & 4 & 26.0 & 16.0 & 12.0 & 1.7 \\
\hline 05/09/2006 & $<0.20$ & $<0.20$ & 29.0 & 9.0 & 2.3 & 3 & 20.0 & 12.0 & 3.9 & $<1.47$ \\
\hline 05/17/2006 & .30 & -- & 13.0 & -- & $<1.2$ & -- & 12.0 & -- & 2.1 & -- \\
\hline $05 / 24 / 2006$ & .12 & .15 & 23.2 & 47.4 & 2 & 4.1 & 23.9 & 34.7 & 14.1 & 21.3 \\
\hline 05/30/2006 & .04 & .09 & 17.8 & 22.4 & 3.6 & 1.9 & 17.9 & 15.1 & 7.6 & 14.2 \\
\hline 06/10/2006 & $<0.20$ & $<0.20$ & 5.4 & 14.0 & 2.6 & 2.1 & 6.3 & 19.0 & $<1.47$ & 7.4 \\
\hline $06 / 18 / 2006$ & .27 & -- & 12.0 & -- & 2.1 & -- & 11.0 & -- & 5.0 & -- \\
\hline 07/11/2006 & .03 & .39 & 6.9 & 147.2 & $<1.2$ & 1.3 & 6.8 & 44.2 & 1.0 & 13.2 \\
\hline 07/20/2006 & $<0.20$ & 1.54 & 14.0 & 521.7 & 1.9 & 2.3 & 11.0 & 162.8 & 4.9 & 42.2 \\
\hline $07 / 27 / 2006$ & $<0.20$ & $<0.20$ & 9.0 & 37.0 & $<1.2$ & 1.3 & 7.2 & 16.0 & 5.5 & 10.0 \\
\hline 08/06/2006 & $<0.20$ & $<0.20$ & 6.7 & 9.3 & 1.4 & 3.2 & 6.1 & 24.0 & 1.9 & 3.2 \\
\hline 08/17/2006 & $<0.20$ & .20 & 16.0 & 26.0 & 3.2 & 4.6 & 15.0 & 26.0 & 6.2 & 5.6 \\
\hline 08/24/2006 & $<0.20$ & $<0.20$ & 9.8 & 9.3 & $<1.2$ & 1.4 & 6.7 & 11.0 & 4.6 & 7.6 \\
\hline $08 / 25 / 2006$ & $<0.20$ & $<0.20$ & 6.0 & 16.0 & $<1.2$ & $<1.2$ & 4.2 & 8.0 & 3.4 & 6.7 \\
\hline 09/03/2006 & $<0.20$ & $<0.20$ & 6.9 & 9.0 & 1.8 & 3.3 & 4.0 & 10.0 & $<1.47$ & 5.9 \\
\hline 09/10/2006 & $<0.20$ & .86 & 24.0 & 148.4 & 1.5 & 2.5 & 7.1 & 54.6 & 4.8 & 16.6 \\
\hline
\end{tabular}


Appendix 1. Detailed street-dirt and water-quality data-Continued.

Appendix table 1-8b. Constituent event mean concentrations measured at the control and high-frequency broom basin outlets during the calibration phase-Continued.

[ $\mu \mathrm{g} / \mathrm{L}$, microgram per liter; mg/L, milligram per liter; <, less than; --, no data]

\begin{tabular}{|c|c|c|c|c|c|c|c|c|c|c|}
\hline \multirow[b]{2}{*}{ Event date } & \multicolumn{2}{|c|}{$\begin{array}{c}\text { Magnesium, } \\
\text { total recoverable } \\
(\mathrm{mg} / \mathrm{L})\end{array}$} & \multicolumn{2}{|c|}{$\begin{array}{c}\text { Phosphorus, } \\
\text { total recoverable } \\
\text { (mg/L) }\end{array}$} & \multicolumn{2}{|c|}{$\begin{array}{l}\text { Orthophosphorus, } \\
\text { dissolved } \\
\text { (mg/L) }\end{array}$} & \multicolumn{2}{|c|}{$\begin{array}{c}\text { Zinc, } \\
\text { dissolved } \\
(\mu \mathrm{g} / \mathrm{L})\end{array}$} & \multicolumn{2}{|c|}{$\begin{array}{c}\text { Zinc, } \\
\text { total recoverable } \\
(\mu \mathrm{g} / \mathrm{L})\end{array}$} \\
\hline & Control & Broom & Control & Broom & Control & Broom & Control & Broom & Control & Broom \\
\hline $09 / 07 / 2001$ & 6.4 & -- & 0.30 & -- & 0.13 & -- & 4.6 & -- & 28.0 & -- \\
\hline $09 / 17 / 2001$ & 17.0 & -- & .28 & -- & .13 & -- & 4.4 & -- & 27.0 & -- \\
\hline 09/19/2001 & 2.4 & -- & .19 & -- & .12 & -- & 8.6 & -- & 11.0 & -- \\
\hline $04 / 07 / 2002$ & 6.2 & -- & .15 & -- & $<0.05$ & -- & 2.8 & -- & 29.0 & -- \\
\hline $04 / 18 / 2002$ & 30.8 & -- & .64 & -- & .11 & -- & 5.9 & -- & 97.0 & -- \\
\hline $05 / 11 / 2002$ & 18.8 & -- & .69 & -- & .10 & -- & 7.6 & -- & 65.0 & -- \\
\hline $05 / 25 / 2002$ & 5.5 & -- & .90 & -- & .25 & -- & 11 & -- & 43.0 & -- \\
\hline $05 / 28 / 2002$ & 18.2 & -- & .67 & -- & .19 & -- & 9.7 & -- & 100.0 & -- \\
\hline $06 / 02 / 2002$ & 45.5 & -- & .72 & -- & .18 & -- & 15 & -- & 56.0 & -- \\
\hline $06 / 10 / 2002$ & 15.3 & -- & 1.17 & -- & .64 & -- & 12 & -- & 82.0 & -- \\
\hline $06 / 26 / 2002$ & 11.1 & -- & .84 & -- & .43 & -- & 16 & -- & 70.0 & -- \\
\hline $07 / 22 / 2002$ & 11.1 & 7.9 & .58 & 1.51 & .20 & 0.67 & 10 & 35 & 66.0 & 119.0 \\
\hline $08 / 17 / 2002$ & 16.0 & -- & .50 & -- & .14 & -- & 8.1 & -- & 73.0 & -- \\
\hline $08 / 21 / 2002$ & 7.1 & -- & .29 & -- & .08 & -- & 3.6 & -- & 40.0 & -- \\
\hline $09 / 02 / 2002$ & 6.0 & 3.6 & .40 & .35 & .20 & .15 & 6.4 & 7.8 & 34.0 & 38.0 \\
\hline $09 / 19 / 2002$ & 52.8 & -- & .51 & -- & .12 & -- & 4.1 & -- & 69.0 & -- \\
\hline $09 / 20 / 2002$ & 2.4 & -- & .25 & -- & .10 & -- & 8.4 & -- & 23.0 & -- \\
\hline $04 / 06 / 2005$ & 24.6 & 36.5 & .60 & .81 & .13 & .10 & 4.4 & 2.6 & 96.7 & 135.9 \\
\hline $04 / 12 / 2005$ & 4.9 & 6.2 & .38 & .87 & .15 & .14 & 4.9 & 8.5 & 40.0 & 71.8 \\
\hline $04 / 19 / 2005$ & 20.0 & -- & 1.68 & -- & .68 & -- & 17 & -- & 174.0 & -- \\
\hline $05 / 06 / 2005$ & 16.6 & 16.0 & .83 & .88 & .04 & .07 & 8.6 & 7.8 & 156.2 & 172.9 \\
\hline $05 / 11 / 2005$ & 4.6 & 6.3 & .44 & .57 & .14 & .17 & 7 & 12 & 46.5 & 79.3 \\
\hline $05 / 13 / 2005$ & 4.4 & 30.1 & .29 & .41 & .05 & .07 & 5.5 & 1.3 & 35.7 & 100.8 \\
\hline $05 / 18 / 2005$ & 5.1 & 5.1 & .47 & .59 & .12 & .17 & 2.3 & 7.2 & 47.7 & 63.3 \\
\hline $04 / 16 / 2006$ & 18.6 & 17.8 & .53 & .80 & .06 & .14 & 1.2 & 2.9 & 83.4 & 109.8 \\
\hline $04 / 29 / 2006$ & 9.1 & 3.7 & 11.00 & .53 & .13 & .12 & 9 & 19 & 658.0 & 51.0 \\
\hline 05/09/2006 & 8.9 & 2.7 & 3.57 & .85 & .42 & .23 & 21 & 18 & 92.0 & 66.0 \\
\hline 05/17/2006 & 4.8 & -- & .88 & -- & .29 & -- & 7.4 & -- & 49.0 & -- \\
\hline $05 / 24 / 2006$ & 11.7 & 25.1 & .80 & 1.14 & .12 & .31 & 1.2 & 2.7 & 65.5 & 116.3 \\
\hline 05/30/2006 & 8.6 & 11.8 & .66 & .74 & .29 & .22 & 3.4 & 4.4 & 40.3 & 68.3 \\
\hline 06/10/2006 & 2.0 & 5.4 & .65 & 1.39 & .29 & .57 & 1.8 & 4 & 24.0 & 84.0 \\
\hline $06 / 18 / 2006$ & 5.0 & -- & .64 & -- & .22 & -- & 7.6 & -- & 43.0 & -- \\
\hline $07 / 11 / 2006$ & 2.8 & 81.0 & .27 & 1.05 & .09 & .14 & 1.9 & 3.9 & 27.2 & 173.8 \\
\hline 07/20/2006 & 6.1 & 264.0 & .48 & 3.18 & .15 & .23 & 4.5 & 5.2 & 42.0 & 794.9 \\
\hline $07 / 27 / 2006$ & 4.3 & 19.0 & .29 & .68 & .09 & .14 & 3.6 & 3.3 & 35.0 & 67.0 \\
\hline 08/06/2006 & 2.3 & 3.4 & .39 & .64 & .25 & .39 & 3.6 & 6.8 & 22.0 & 43.0 \\
\hline 08/17/2006 & 5.6 & 12.0 & .76 & .88 & .32 & .40 & 8 & 11 & 66.0 & 90.0 \\
\hline $08 / 24 / 2006$ & 4.4 & 5.0 & .28 & .43 & .10 & .17 & 2.4 & 2.5 & 24.0 & 39.0 \\
\hline $08 / 25 / 2006$ & 2.4 & 7.7 & .18 & .34 & .07 & .12 & 2.5 & 2.6 & 16.0 & 33.0 \\
\hline 09/03/2006 & 2.8 & 3.5 & .32 & .50 & .20 & .31 & 6 & 10 & 17.0 & 38.0 \\
\hline 09/10/2006 & 12.0 & 85.7 & .23 & 1.07 & .09 & .19 & 2.6 & 5.7 & 24.0 & $1,183.7$ \\
\hline
\end{tabular}


Appendix 1. Detailed street-dirt and water-quality data-Continued.

Appendix table 1-8b. Constituent event mean concentrations measured the control and high-frequency broom basin outlets during the calibration phase-Continued.

[ $\mu \mathrm{g} / \mathrm{L}$, microgram per liter; mg/L, milligram per liter; <, less than; --, no data]

\begin{tabular}{|c|c|c|c|c|c|c|c|c|}
\hline \multirow[b]{2}{*}{ Event date } & \multicolumn{2}{|c|}{$\begin{array}{c}\text { Ammonia-nitrogen } \\
(\mathrm{mg} / \mathrm{L})\end{array}$} & \multicolumn{2}{|c|}{$\begin{array}{c}\text { Nitrate plus nitrite, } \\
\text { dissolved } \\
\text { (mg/L) }\end{array}$} & \multicolumn{2}{|c|}{$\begin{array}{c}\text { Dissolved solids, } \\
\text { total } \\
\text { (mg/L) }\end{array}$} & \multicolumn{2}{|c|}{$\begin{array}{c}\text { Suspended sediment, } \\
\text { total } \\
(\mathrm{mg} / \mathrm{L})\end{array}$} \\
\hline & Control & Broom & Control & Broom & Control & Broom & Control & Broom \\
\hline 09/07/2001 & 0.19 & -- & 0.42 & -- & 148 & -- & 230 & -- \\
\hline 09/17/2001 & $<0.05$ & -- & .67 & -- & 168 & -- & 161 & -- \\
\hline 09/19/2001 & .18 & -- & .58 & -- & 56 & -- & 39 & -- \\
\hline 04/07/2002 & .30 & -- & .27 & -- & 72 & -- & 227 & -- \\
\hline $04 / 18 / 2002$ & .76 & -- & .40 & -- & 54 & -- & 1,241 & -- \\
\hline $05 / 11 / 2002$ & .38 & -- & .35 & -- & 59 & -- & 853 & -- \\
\hline $05 / 25 / 2002$ & .58 & -- & .37 & -- & 70 & -- & 428 & -- \\
\hline $05 / 28 / 2002$ & .91 & -- & 1.01 & -- & 58 & -- & 851 & -- \\
\hline $06 / 02 / 2002$ & .57 & -- & .49 & -- & 46 & -- & 3,394 & -- \\
\hline $06 / 10 / 2002$ & .73 & -- & .61 & -- & 80 & -- & 688 & -- \\
\hline $06 / 26 / 2002$ & .76 & -- & .85 & -- & 42 & -- & 450 & -- \\
\hline $07 / 22 / 2002$ & .56 & $<0.05$ & .46 & $<0.18$ & 40 & 94 & 932 & 506 \\
\hline $08 / 17 / 2002$ & .47 & -- & .76 & -- & 60 & -- & 611 & -- \\
\hline $08 / 21 / 2002$ & .23 & -- & .29 & -- & 92 & 15 & 440 & -- \\
\hline $09 / 02 / 2002$ & .61 & .33 & .67 & .56 & 62 & -- & 440 & 154 \\
\hline $09 / 19 / 2002$ & .25 & -- & .32 & -- & 38 & -- & 1,324 & -- \\
\hline $09 / 20 / 2002$ & .20 & -- & .24 & -- & 58 & 50 & 57 & -- \\
\hline 04/06/2005 & .90 & .76 & .41 & .43 & 86 & 78 & 549 & 1,381 \\
\hline $04 / 12 / 2005$ & .84 & .84 & 1.04 & 1.10 & 60 & 76 & 100 & 130 \\
\hline $04 / 19 / 2005$ & 2.32 & -- & 1.43 & -- & 154 & -- & 536 & -- \\
\hline 05/06/2005 & 1.08 & 1.22 & .64 & .74 & 56 & 58 & 644 & 569 \\
\hline $05 / 11 / 2005$ & .52 & .57 & .35 & .39 & 40 & 60 & 144 & 240 \\
\hline 05/13/2005 & .49 & .45 & .48 & .44 & 40 & 55 & 159 & 1,697 \\
\hline 05/18/2005 & .64 & .70 & .76 & .84 & 62 & 72 & 141 & 173 \\
\hline $04 / 16 / 2006$ & .32 & .41 & .27 & .38 & 24 & 46 & 602 & 878 \\
\hline $04 / 29 / 2006$ & .56 & .61 & .44 & .48 & 40 & 67 & 113 & 266 \\
\hline 05/09/2006 & .55 & .68 & .39 & .56 & 130 & 98 & 392 & 121 \\
\hline 05/17/2006 & .55 & -- & .38 & -- & 86 & -- & 203 & -- \\
\hline $05 / 24 / 2006$ & .77 & .78 & .42 & .57 & 72 & 94 & 555 & 1,228 \\
\hline $05 / 30 / 2006$ & .65 & .40 & .49 & .43 & 122 & 76 & 253 & 703 \\
\hline $06 / 10 / 2006$ & .23 & .44 & .26 & .25 & 44 & 49 & 51 & 443 \\
\hline $06 / 18 / 2006$ & .52 & -- & .58 & -- & 77 & -- & 183 & -- \\
\hline 07/11/2006 & .06 & $<0.025$ & $<0.18$ & .55 & 30 & 44 & 119 & 3,282 \\
\hline $07 / 20 / 2006$ & .49 & .38 & .53 & .49 & 44 & 36 & 191 & 13,473 \\
\hline $07 / 27 / 2006$ & .60 & .50 & .33 & .35 & 42 & 40 & 150 & 841 \\
\hline 08/06/2006 & .30 & .13 & .42 & .47 & 31 & 48 & 65 & 150 \\
\hline 08/17/2006 & .51 & .31 & .76 & .85 & 54 & 54 & 238 & 648 \\
\hline $08 / 24 / 2006$ & .56 & .39 & .43 & .44 & 30 & 32 & 173 & 541 \\
\hline $08 / 25 / 2006$ & .48 & .39 & .52 & .54 & 22 & 32 & 95 & 129 \\
\hline 09/03/2006 & .15 & .25 & .31 & .35 & 57 & 84 & 63 & 203 \\
\hline 09/10/2006 & .18 & .15 & .59 & .35 & 224 & 74 & 135 & 4,145 \\
\hline
\end{tabular}


Appendix 1. Detailed street-dirt and water-quality data-Continued.

Appendix table 1-8c. Constituent event mean concentrations measured at the control and air-sweeper basin outlets during the treatment phase.

[ug/L, microgram per liter; mg/L, milligram per liter; <, less than; --, no data]

\begin{tabular}{|c|c|c|c|c|c|c|c|c|c|c|c|}
\hline \multirow{2}{*}{ 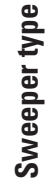 } & \multirow[b]{2}{*}{ Event date } & \multicolumn{2}{|c|}{$\begin{array}{c}\text { Cadmium, } \\
\text { total recoverable } \\
(\mu \mathrm{g} / \mathrm{L})\end{array}$} & \multicolumn{2}{|c|}{$\begin{array}{c}\text { Calcium, } \\
\text { total recoverable } \\
(\mathrm{mg} / \mathrm{L})\end{array}$} & \multicolumn{2}{|c|}{$\begin{array}{l}\text { Copper, } \\
\text { dissolved } \\
(\mu \mathrm{g} / \mathrm{L})\end{array}$} & \multicolumn{2}{|c|}{$\begin{array}{c}\text { Copper, } \\
\text { total recoverable } \\
(\mu \mathrm{g} / \mathrm{L})\end{array}$} & \multicolumn{2}{|c|}{$\begin{array}{c}\text { Lead, } \\
\text { total recoverable } \\
(\mu \mathrm{g} / \mathrm{L})\end{array}$} \\
\hline & & Control & Air & Control & Air & Control & Air & Control & Air & Control & Air \\
\hline \multirow{14}{*}{ 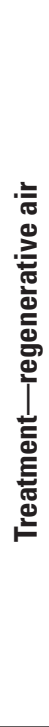 } & $04 / 30 / 2003$ & 0.50 & 0.27 & 18.9 & 18.5 & 4.1 & 5.9 & 17.0 & 19.0 & 12.0 & 9.6 \\
\hline & 04/30/2003 & .79 & $<0.17$ & 68.9 & 66.5 & 1.4 & $<1.34$ & 17.5 & 25.1 & 10.0 & 19.6 \\
\hline & $05 / 04 / 2003$ & .58 & $<0.17$ & 25.4 & 8.3 & 2 & 2.7 & 13.0 & 8.6 & 4.2 & 3.6 \\
\hline & 05/10/2003 & .30 & .34 & 40.9 & 34.2 & 4.8 & 2.7 & 40.0 & 20.0 & 19.0 & 13.0 \\
\hline & $05 / 14 / 2003$ & $<0.17$ & $<0.17$ & 21.0 & 11.4 & 3 & 3.1 & 16.0 & 12.0 & 5.3 & 3.4 \\
\hline & 05/19/2003 & 34.00 & .30 & 206.8 & 47.0 & 6.3 & 3.7 & 52.7 & 24.0 & 13.0 & 16.0 \\
\hline & $05 / 30 / 2003$ & .46 & .48 & 97.0 & 152.0 & 2.3 & 1.8 & 48.0 & 39.0 & 33.0 & 27.0 \\
\hline & $07 / 15 / 2003$ & .17 & .29 & 39.0 & 12.0 & 3.3 & 14 & 16.0 & 9.7 & 13.0 & 12.0 \\
\hline & $09 / 12 / 2003$ & .17 & $<0.17$ & 24.0 & 20.0 & 12 & 4.5 & 27.0 & 13.0 & 9.9 & 6.9 \\
\hline & 05/08/2004 & $<0.2$ & $<0.2$ & 158.0 & 82.9 & 8.4 & 5.8 & 43.9 & 26.8 & 36.6 & 31.9 \\
\hline & 05/10/2004 & .24 & .21 & 79.4 & 105.2 & 4.5 & 3 & 24.7 & 24.1 & 19.8 & 29.4 \\
\hline & 05/13/2004 & -- & -- & -- & -- & -- & -- & -- & -- & -- & -- \\
\hline & $05 / 17 / 2004$ & $<0.20$ & .25 & 41.6 & 94.9 & 4.8 & 3.3 & 22.4 & 23.1 & 22.2 & 33.0 \\
\hline & $05 / 21 / 2004$ & $<0.20$ & .28 & 83.4 & 34.5 & 1.8 & 1.8 & 23.5 & 18.6 & 22.0 & 24.8 \\
\hline \multirow{22}{*}{ 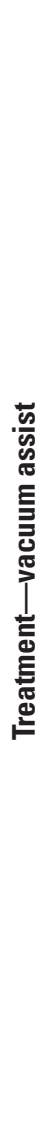 } & 05/29/2004 & $<0.20$ & $<0.20$ & 137.8 & 15.4 & 2.1 & 5.6 & 74.4 & 12.6 & 25.6 & 8.7 \\
\hline & 06/10/2004 & $<0.20$ & $<0.20$ & 7.5 & 17.3 & 5.3 & 3.5 & 10.5 & 12.9 & 3.8 & 8.4 \\
\hline & 06/10/2004 & $<0.20$ & -- & 4.9 & -- & 4.7 & -- & 3.7 & -- & 1.6 & -- \\
\hline & $06 / 24 / 2004$ & .30 & $<0.20$ & 6.1 & 4.8 & 3 & 2.6 & 5.5 & 4.6 & 3.6 & 4.0 \\
\hline & 07/09/2004 & .25 & .21 & 9.0 & 24.0 & 5.8 & 4.2 & 11.9 & 16.6 & 6.8 & 15.3 \\
\hline & $07 / 16 / 2004$ & $<0.20$ & .21 & 11.9 & 18.3 & 4 & 2.6 & 12.3 & 13.1 & 6.7 & 13.5 \\
\hline & $07 / 21 / 2004$ & $<0.20$ & $<0.20$ & 6.3 & 7.0 & 4.2 & 2.8 & 5.9 & 6.4 & $<1.49$ & 4.0 \\
\hline & 07/29/2004 & .20 & .22 & 7.1 & 11.0 & 2.6 & 2.6 & 5.1 & 8.7 & 2.4 & 8.1 \\
\hline & 08/03/2004 & .21 & .06 & 11.2 & 19.8 & $<1.64$ & $<1.64$ & 7.0 & 13.5 & 8.7 & 13.8 \\
\hline & 08/17/2004 & $<0.20$ & $<0.20$ & 9.2 & 13.1 & $<1.64$ & $<1.64$ & 7.8 & 9.5 & 5.0 & 8.5 \\
\hline & 08/18/2004 & .21 & $<0.20$ & 9.5 & 22.9 & $<1.64$ & $<1.64$ & 20.8 & 16.2 & 3.9 & 16.9 \\
\hline & $08 / 24 / 2004$ & .26 & $<0.20$ & 19.3 & 11.4 & $<1.64$ & 1.7 & 10.8 & 12.1 & 2.9 & 6.5 \\
\hline & $08 / 27 / 2004$ & $<0.20$ & .35 & 57.0 & 11.0 & $<1.64$ & $<1.64$ & 17.0 & 10.0 & 6.9 & 8.9 \\
\hline & 09/01/2004 & .11 & $<0.20$ & 11.7 & 17.3 & $<1.64$ & $<1.64$ & 8.9 & 12.9 & 7.8 & 26.3 \\
\hline & $09 / 15 / 2004$ & $<0.23$ & $<0.23$ & 13.0 & 9.1 & 3.2 & 3.2 & 13.0 & 8.7 & 3.5 & 3.5 \\
\hline & 04/06/2005 & .24 & .32 & 48.7 & 46.9 & 2.5 & 3.6 & 22.1 & 26.1 & 22.3 & 22.5 \\
\hline & $04 / 12 / 2005$ & $<0.23$ & $<0.23$ & 12.0 & 6.8 & $<1.34$ & 2.1 & 11.0 & 10.0 & 5.4 & 4.1 \\
\hline & 04/19/2005 & $<0.23$ & .47 & 46.0 & 98.0 & 3.9 & 2.9 & 32.0 & 50.0 & 22.0 & 39.0 \\
\hline & 05/06/2005 & .37 & .04 & 37.2 & 28.4 & 3.8 & 2.4 & 34.8 & 20.7 & 19.4 & 17.8 \\
\hline & 05/11/2005 & $<0.23$ & $<0.23$ & 12.1 & 9.9 & 2.9 & 1.5 & 9.0 & 9.2 & 6.5 & 6.4 \\
\hline & $05 / 13 / 2005$ & $<0.23$ & $<0.23$ & 11.1 & 15.4 & $<1.34$ & $<1.34$ & 6.5 & 10.0 & 8.1 & 8.8 \\
\hline & 05/18/2005 & .25 & $<0.23$ & 13.1 & 11.0 & 1.4 & 2 & 9.8 & 9.0 & 9.5 & 6.4 \\
\hline
\end{tabular}


Appendix 1. Detailed street-dirt and water-quality data-Continued.

Appendix table 1-8c. Constituent event mean concentrations measured the control and air-sweeper basin outlets during the treatment phase-Continued.

[ $\mu \mathrm{g} / \mathrm{L}$, microgram per liter; mg/L, milligram per liter; <, less than; --, no data]

\begin{tabular}{|c|c|c|c|c|c|c|c|c|c|c|c|}
\hline \multirow{2}{*}{ 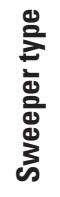 } & \multirow[b]{2}{*}{ Event Date } & \multicolumn{2}{|c|}{$\begin{array}{l}\text { Magnesium, } \\
\text { total recoverable } \\
(\mathrm{mg} / \mathrm{L})\end{array}$} & \multicolumn{2}{|c|}{$\begin{array}{c}\text { Phosphorus, } \\
\text { total recoverable } \\
\text { (mg/L) }\end{array}$} & \multicolumn{2}{|c|}{$\begin{array}{l}\text { Orthophosphorus, } \\
\text { dissolved } \\
\text { (mg/L) }\end{array}$} & \multicolumn{2}{|c|}{$\begin{array}{c}\text { Zinc, } \\
\text { dissolved } \\
(\mu \mathrm{g} / \mathrm{L})\end{array}$} & \multicolumn{2}{|c|}{$\begin{array}{c}\text { Zinc, } \\
\text { total recoverable } \\
(\mu \mathrm{g} / \mathrm{L})\end{array}$} \\
\hline & & Control & Air & Control & Air & Control & Air & Control & Air & Control & Air \\
\hline \multirow{14}{*}{ 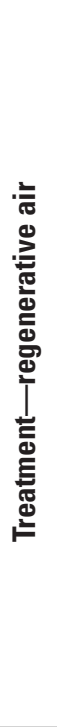 } & $04 / 30 / 2003$ & 8.2 & 7.7 & 0.72 & 0.75 & 0.20 & 0.30 & 12 & 16 & 86.0 & 89.0 \\
\hline & $04 / 30 / 2003$ & 37.5 & 33.3 & .63 & .61 & .08 & .07 & 4.4 & 4.7 & 86.7 & 95.6 \\
\hline & 05/04/2003 & 9.1 & 2.5 & 4.04 & .36 & $<0.05$ & .14 & 7.2 & 10 & 111.0 & 37.0 \\
\hline & 05/10/2003 & 17.2 & 13.7 & .83 & .87 & .11 & .13 & 5 & 6.6 & 95.0 & 111.0 \\
\hline & 05/14/2003 & 6.6 & 3.2 & .95 & .73 & .31 & .26 & 9.5 & 12 & 52.0 & 54.0 \\
\hline & 05/19/2003 & 109.7 & 22.5 & 1.34 & .87 & .19 & .18 & 4.9 & 9.9 & 152.4 & 126.0 \\
\hline & 05/30/2003 & 48.1 & 76.8 & 1.34 & 1.21 & .18 & .18 & 4.7 & 2.7 & 150.0 & 207.0 \\
\hline & $07 / 15 / 2003$ & 19.0 & 5.2 & .60 & .33 & .10 & .13 & 5.5 & 63 & 64.0 & 37.0 \\
\hline & $09 / 12 / 2003$ & 11.0 & 6.2 & .72 & .51 & .32 & .27 & 12 & 6.5 & 64.0 & 70.0 \\
\hline & 05/08/2004 & 76.7 & 34.3 & 1.23 & 1.52 & .12 & .09 & 21 & 24 & 148.9 & 164.2 \\
\hline & 05/10/2004 & 39.2 & 58.7 & .68 & .76 & .07 & .07 & 9.3 & 12 & 83.8 & 164.1 \\
\hline & $05 / 13 / 2004$ & -- & -- & -- & -- & -- & -- & -- & -- & -- & -- \\
\hline & 05/17/2004 & 21.3 & 46.0 & .52 & .74 & .18 & .19 & 6 & 83 & 86.9 & 132.0 \\
\hline & $05 / 21 / 2004$ & 43.8 & 17.8 & .62 & .63 & .20 & .14 & 3.4 & 4.5 & 72.2 & 99.3 \\
\hline \multirow{22}{*}{ 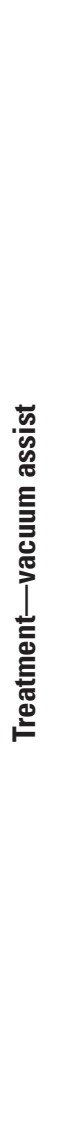 } & 05/29/2004 & 69.2 & 7.4 & .66 & .33 & .13 & .09 & 4.1 & 7.5 & 64.3 & 55.8 \\
\hline & 06/10/2004 & 2.9 & 6.1 & .65 & .43 & .35 & .17 & 16 & 11 & 36.9 & 73.3 \\
\hline & 06/10/2004 & 1.6 & -- & .18 & -- & .08 & -- & 4.4 & -- & 14.0 & -- \\
\hline & $06 / 24 / 2004$ & 2.2 & 1.6 & .19 & .15 & .09 & .08 & 4.7 & 8.2 & 22.6 & 25.2 \\
\hline & 07/09/2004 & 4.4 & 12.0 & .32 & .29 & .11 & .10 & 11 & 8.2 & 46.1 & 82.7 \\
\hline & $07 / 16 / 2004$ & 5.5 & 9.1 & .43 & .35 & .17 & .12 & 8.6 & 5.5 & 58.5 & 76.7 \\
\hline & $07 / 21 / 2004$ & 2.2 & 2.6 & .24 & .32 & .13 & .15 & 16 & 21 & 19.0 & 46.0 \\
\hline & 07/29/2004 & 3.1 & 5.2 & .36 & .42 & .12 & .11 & 9.6 & 9.1 & 26.0 & 51.0 \\
\hline & 08/03/2004 & 5.6 & 10.5 & .32 & .42 & .08 & .10 & 2 & 1 & 36.5 & 63.2 \\
\hline & 08/17/2004 & 3.9 & 6.1 & .50 & .50 & .23 & .21 & 2 & 3.4 & 43.6 & 120.8 \\
\hline & 08/18/2004 & 4.3 & 12.4 & .37 & .57 & .13 & .14 & 3.4 & 1.8 & 38.0 & 89.6 \\
\hline & $08 / 24 / 2004$ & 9.6 & 5.3 & .43 & .47 & .24 & .23 & 2.4 & 9.4 & 29.1 & 64.8 \\
\hline & 08/27/2004 & 30.0 & 5.2 & .56 & .48 & .12 & .20 & .8 & 4.4 & 37.0 & 49.0 \\
\hline & 09/01/2004 & 5.8 & 9.4 & .29 & .52 & .13 & .12 & 2.6 & 1.6 & 35.1 & 62.7 \\
\hline & $09 / 15 / 2004$ & 5.0 & 3.3 & 1.05 & .91 & .53 & .47 & 4.2 & 4.9 & 48.0 & 51.0 \\
\hline & 04/06/2005 & 24.6 & 22.6 & .60 & .65 & .13 & .11 & 4.4 & 4.3 & 96.7 & 147.7 \\
\hline & $04 / 12 / 2005$ & 4.9 & 2.2 & .38 & .31 & .15 & .15 & 4.9 & 13 & 40.0 & 43.0 \\
\hline & 04/19/2005 & 20.0 & 47.0 & 1.68 & 2.04 & .68 & .68 & 17 & 11 & 174.0 & 320.0 \\
\hline & 05/06/2005 & 16.6 & 12.7 & .83 & .66 & .04 & $<0.03$ & 8.6 & 11 & 156.2 & 140.5 \\
\hline & 05/11/2005 & 4.6 & 3.5 & .44 & .38 & .14 & .17 & 7 & 9.7 & 46.5 & 51.2 \\
\hline & 05/13/2005 & 4.4 & 7.1 & .29 & .29 & .05 & .05 & 5.5 & 2.8 & 35.7 & 60.4 \\
\hline & $05 / 18 / 2005$ & 5.1 & 4.0 & .47 & .41 & .12 & .09 & 2.3 & 5.2 & 47.7 & 50.0 \\
\hline
\end{tabular}


Appendix 1. Detailed street-dirt and water-quality data-Continued.

Appendix table 1-8c. Constituent event mean concentrations measured at the control and air-sweeper basin outlets during the treatment phase-Continued.

[ $\mu \mathrm{g} / \mathrm{L}$, microgram per liter; mg/L, milligram per liter; <, less than; --, no data]

\begin{tabular}{|c|c|c|c|c|c|c|c|c|c|}
\hline \multirow{2}{*}{ 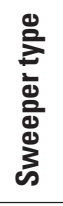 } & \multirow[b]{2}{*}{ Event Date } & \multicolumn{2}{|c|}{$\begin{array}{c}\text { Ammonia-nitrogen } \\
(\mathrm{mg} / \mathrm{L})\end{array}$} & \multicolumn{2}{|c|}{$\begin{array}{l}\text { Nitrate plus nitrite, } \\
\text { dissolved } \\
\text { (mg/L) }\end{array}$} & \multicolumn{2}{|c|}{$\begin{array}{c}\text { Dissolved solids, } \\
\text { total } \\
\text { (mg/L) }\end{array}$} & \multicolumn{2}{|c|}{$\begin{array}{c}\text { Suspended sediment, } \\
\text { total } \\
(\mathrm{mg} / \mathrm{L})\end{array}$} \\
\hline & & Control & Air & Control & Air & Control & Air & Control & Air \\
\hline \multirow{14}{*}{ 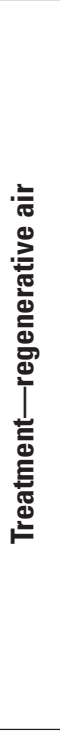 } & $04 / 30 / 2003$ & 0.78 & 0.86 & 0.49 & 0.50 & 64 & 87 & 308 & 301 \\
\hline & $04 / 30 / 2003$ & .32 & .29 & .29 & .24 & 36 & 42 & 1,270 & 1,074 \\
\hline & $05 / 04 / 2003$ & .38 & .42 & .29 & .15 & 86 & 71 & 280 & 102 \\
\hline & $05 / 10 / 2003$ & .62 & .43 & .45 & .25 & 76 & 94 & 972 & 549 \\
\hline & $05 / 14 / 2003$ & .58 & .26 & .41 & .39 & 146 & 90 & 171 & 111 \\
\hline & $05 / 19 / 2003$ & .91 & .84 & .78 & .61 & 90 & 70 & 3,193 & 847 \\
\hline & $05 / 30 / 2003$ & .77 & .70 & .40 & .49 & 75 & 68 & 1,754 & 2,666 \\
\hline & $07 / 15 / 2003$ & .55 & .39 & .54 & .33 & 46 & 21 & 794 & 1,344 \\
\hline & $09 / 12 / 2003$ & .77 & .75 & .95 & .82 & 102 & 94 & -- & -- \\
\hline & 05/08/2004 & 1.27 & 1.17 & .75 & .89 & 52 & 64 & 3,360 & 1,348 \\
\hline & 05/10/2004 & .70 & .62 & .49 & .42 & 56 & 32 & 1,756 & 1,540 \\
\hline & 05/13/2004 & -- & -- & .27 & .34 & 52 & 72 & 155 & 148 \\
\hline & $05 / 17 / 2004$ & .62 & .53 & .35 & .31 & 50 & 42 & 1,036 & 1,410 \\
\hline & $05 / 21 / 2004$ & .48 & .43 & .42 & .35 & 79 & 48 & 1,543 & 874 \\
\hline \multirow{22}{*}{ 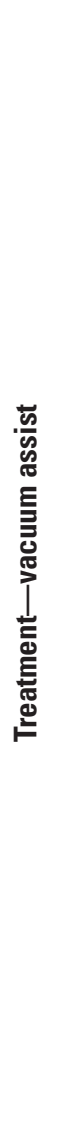 } & $05 / 29 / 2004$ & .30 & .29 & .30 & .33 & 61 & 62 & 2,992 & 366 \\
\hline & 06/10/2004 & .49 & .28 & .39 & .42 & 84 & 81 & 132 & 252 \\
\hline & 06/10/2004 & .22 & -- & .28 & -- & 66 & 70 & 55 & -- \\
\hline & $06 / 24 / 2004$ & .26 & .26 & .29 & .28 & 78 & 64 & 62 & 35 \\
\hline & 07/09/2004 & .32 & .32 & .37 & .38 & 52 & 48 & 233 & 448 \\
\hline & $07 / 16 / 2004$ & .29 & .22 & .48 & .36 & 54 & 41 & 261 & 386 \\
\hline & $07 / 21 / 2004$ & .28 & .30 & .52 & .54 & 66 & 60 & 36 & 78 \\
\hline & $07 / 29 / 2004$ & .34 & .35 & .36 & .41 & 42 & 56 & 197 & 290 \\
\hline & 08/03/2004 & .15 & .14 & .30 & .26 & 34 & 44 & 282 & 555 \\
\hline & 08/17/2004 & .38 & .38 & .52 & .56 & 31 & 42 & 188 & 264 \\
\hline & 08/18/2004 & .30 & .34 & .33 & .29 & 32 & 46 & 188 & 564 \\
\hline & $08 / 24 / 2004$ & .21 & .22 & .50 & .42 & 98 & 49 & 146 & 240 \\
\hline & $08 / 27 / 2004$ & .21 & .25 & .33 & .35 & 98 & 48 & 589 & 182 \\
\hline & $09 / 01 / 2004$ & .26 & .31 & .32 & .35 & 42 & 43 & 207 & 523 \\
\hline & $09 / 15 / 2004$ & .08 & .17 & .32 & .49 & 80 & 80 & 64 & 71 \\
\hline & $04 / 06 / 2005$ & .90 & .85 & .41 & .39 & 86 & 86 & 549 & 936 \\
\hline & $04 / 12 / 2005$ & .84 & .77 & 1.04 & .80 & 60 & 52 & 100 & 50 \\
\hline & $04 / 19 / 2005$ & 2.32 & 1.74 & 1.43 & 1.20 & 154 & 163 & 536 & 1,196 \\
\hline & $05 / 06 / 2005$ & 1.08 & 1.09 & .64 & .65 & 56 & 60 & 644 & 414 \\
\hline & $05 / 11 / 2005$ & .52 & .52 & .35 & .37 & 40 & 45 & 144 & 155 \\
\hline & $05 / 13 / 2005$ & .49 & .50 & .48 & .52 & 40 & 50 & 159 & 258 \\
\hline & 05/18/2005 & .64 & .59 & .76 & .79 & 62 & 68 & 141 & 102 \\
\hline
\end{tabular}


Appendix 1. Detailed street-dirt and water-quality data-Continued.

Appendix table 1-8d. Constituent event mean concentrations measured the control and high-frequency broom basin outlets during the treatment phase.

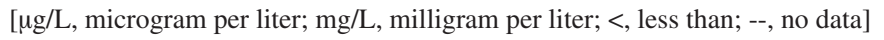

\begin{tabular}{|c|c|c|c|c|c|c|c|c|c|c|}
\hline \multirow[b]{2}{*}{ Event date } & \multicolumn{2}{|c|}{$\begin{array}{c}\text { Cadmium, } \\
\text { total recoverable } \\
(\mu \mathrm{g} / \mathrm{L})\end{array}$} & \multicolumn{2}{|c|}{$\begin{array}{c}\text { Calcium, } \\
\text { total recoverable } \\
(\mathrm{mg} / \mathrm{L})\end{array}$} & \multicolumn{2}{|c|}{$\begin{array}{l}\text { Copper, } \\
\text { dissolved } \\
(\mu \mathrm{g} / \mathrm{L})\end{array}$} & \multicolumn{2}{|c|}{$\begin{array}{c}\text { Copper, } \\
\text { total recoverable } \\
(\mu \mathrm{g} / \mathrm{L})\end{array}$} & \multicolumn{2}{|c|}{$\begin{array}{c}\text { Lead, } \\
\text { total recoverable } \\
(\mu \mathrm{g} / \mathrm{L})\end{array}$} \\
\hline & Control & Broom & Control & Broom & Control & Broom & Control & Broom & Control & Broom \\
\hline $04 / 30 / 2003$ & 0.50 & $<0.17$ & 18.9 & 18.8 & 4.1 & 4.9 & 17.0 & 15.0 & 12.0 & 5.6 \\
\hline $04 / 30 / 2003$ & .79 & .25 & 68.9 & 23.1 & 1.4 & 1.6 & 17.5 & 13.0 & 10.0 & 45.0 \\
\hline $05 / 04 / 2003$ & .58 & $<0.17$ & 25.4 & 8.6 & 2 & 2.6 & 13.0 & 7.6 & 4.2 & 2.5 \\
\hline $05 / 10 / 2003$ & .30 & .25 & 40.9 & 22.5 & 4.8 & 2.3 & 40.0 & 11.0 & 19.0 & 7.0 \\
\hline $05 / 14 / 2003$ & $<0.17$ & $<0.17$ & 21.0 & 8.2 & 3 & 13 & 16.0 & 12.0 & 5.3 & 2.2 \\
\hline $05 / 19 / 2003$ & 34.00 & .43 & 206.8 & $1,972.5$ & 6.3 & 4.1 & 52.7 & 785.1 & 13.0 & 350.1 \\
\hline $05 / 30 / 2003$ & .46 & .49 & 97.0 & 192.0 & 2.3 & 1.9 & 48.0 & 42.0 & 33.0 & 29.0 \\
\hline $07 / 15 / 2003$ & .17 & $<0.17$ & 39.0 & 35.0 & 3.3 & 2.5 & 16.0 & 15.0 & 13.0 & 13.0 \\
\hline $09 / 12 / 2003$ & .17 & $<0.17$ & 24.0 & 66.0 & 12 & 4.2 & 27.0 & 20.0 & 9.9 & 8.9 \\
\hline 05/08/2004 & $<0.2$ & $<0.2$ & 158.0 & 34.3 & 8.4 & 6.6 & 43.9 & 24.4 & 36.6 & 13.4 \\
\hline $05 / 10 / 2004$ & .24 & $<0.2$ & 79.4 & 23.9 & 4.5 & 3.4 & 24.7 & 14.3 & 19.8 & 10.6 \\
\hline $05 / 13 / 2004$ & -- & -- & -- & -- & -- & -- & -- & -- & -- & -- \\
\hline $05 / 17 / 2004$ & $<0.20$ & .22 & 41.6 & 87.7 & 4.8 & 5.1 & 22.4 & 25.5 & 22.2 & 17.9 \\
\hline $05 / 21 / 2004$ & $<0.20$ & -- & 83.4 & -- & 1.8 & -- & 23.5 & -- & 22.0 & -- \\
\hline $05 / 29 / 2004$ & $<0.20$ & $<0.20$ & 137.8 & 6.0 & 2.1 & 4.5 & 74.4 & 8.6 & 25.6 & 3.1 \\
\hline $06 / 10 / 2004$ & $<0.20$ & $<0.20$ & 7.5 & 6.6 & 5.3 & 4 & 10.5 & 9.6 & 3.8 & 2.5 \\
\hline $06 / 10 / 2004$ & $<0.20$ & $<0.20$ & 4.9 & 5.6 & 4.7 & 6.4 & 3.7 & 10.7 & 1.6 & .4 \\
\hline $06 / 24 / 2004$ & .30 & $<0.20$ & 6.1 & 5.6 & 3 & 3.1 & 5.5 & 6.0 & 3.6 & .1 \\
\hline 07/09/2004 & .25 & -- & 9.0 & -- & 5.8 & -- & 11.9 & -- & 6.8 & -- \\
\hline $07 / 16 / 2004$ & $<0.20$ & $<0.20$ & 11.9 & 12.7 & 4 & 2.8 & 12.3 & 13.1 & 6.7 & 12.3 \\
\hline $07 / 21 / 2004$ & $<0.20$ & $<0.20$ & 6.3 & 7.0 & 4.2 & 3.4 & 5.9 & 5.8 & $<1.49$ & $<1.49$ \\
\hline $07 / 29 / 2004$ & .20 & $<0.20$ & 7.1 & 11.1 & 2.6 & $<1.64$ & 5.1 & 12.7 & 2.4 & 6.0 \\
\hline 08/03/2004 & .21 & $<0.20$ & 11.2 & 10.6 & $<1.64$ & $<1.64$ & 7.0 & 10.3 & 8.7 & 7.3 \\
\hline 08/17/2004 & $<0.20$ & $<0.20$ & 9.2 & 7.5 & $<1.64$ & 2.3 & 7.8 & 14.0 & 5.0 & 6.4 \\
\hline $08 / 18 / 2004$ & .21 & .21 & 9.5 & 7.7 & $<1.64$ & $<1.64$ & 20.8 & 11.0 & 3.9 & 5.5 \\
\hline $08 / 24 / 2004$ & .26 & -- & 19.3 & -- & $<1.64$ & -- & 10.8 & -- & 2.9 & -- \\
\hline $08 / 27 / 2004$ & $<0.20$ & $<0.20$ & 57.0 & 7.5 & $<1.64$ & 1.66 & 17.0 & 7.4 & 6.9 & 6.6 \\
\hline 09/01/2004 & .11 & -- & 11.7 & -- & $<1.64$ & -- & 8.9 & -- & 7.8 & -- \\
\hline $09 / 15 / 2004$ & $<0.23$ & $<0.23$ & 13.0 & 10.0 & 3.2 & 3.6 & 13.0 & 12.0 & 3.5 & 3.2 \\
\hline
\end{tabular}


Appendix 1. Detailed street-dirt and water-quality data-Continued.

Appendix table 1-8d. Constituent event mean concentrations measured the control and high-frequency broom basin outlets during the treatment phase-Continued.

[ $\mu \mathrm{g} / \mathrm{L}$, microgram per liter; mg/L, milligram per liter; <, less than; --, no data]

\begin{tabular}{|c|c|c|c|c|c|c|c|c|c|c|}
\hline \multirow[b]{2}{*}{ Event date } & \multicolumn{2}{|c|}{$\begin{array}{c}\text { Magnesium, } \\
\text { total recoverable } \\
(\mathrm{mg} / \mathrm{L})\end{array}$} & \multicolumn{2}{|c|}{$\begin{array}{c}\text { Phosphorus, } \\
\text { total recoverable } \\
\text { (mg/L) }\end{array}$} & \multicolumn{2}{|c|}{$\begin{array}{l}\text { Orthophosphorus, } \\
\text { dissolved } \\
\text { (mg/L) }\end{array}$} & \multicolumn{2}{|c|}{$\begin{array}{c}\text { Zinc, } \\
\text { dissolved } \\
(\mu \mathrm{g} / \mathrm{L})\end{array}$} & \multicolumn{2}{|c|}{$\begin{array}{c}\text { Zinc, } \\
\text { total recoverable } \\
(\mu \mathrm{g} / \mathrm{L})\end{array}$} \\
\hline & Control & Broom & Control & Broom & Control & Broom & Control & Broom & Control & Broom \\
\hline $04 / 30 / 2003$ & 8.2 & 7.7 & 0.72 & 0.73 & 0.20 & 0.30 & 12 & 16 & 86.0 & 86.0 \\
\hline $04 / 30 / 2003$ & 37.5 & 9.1 & .63 & .30 & .08 & .09 & 4.4 & 5.5 & 86.7 & 51.0 \\
\hline $05 / 04 / 2003$ & 9.1 & 2.4 & 4.04 & .25 & $<0.05$ & .09 & 7.2 & 11 & 111.0 & 36.0 \\
\hline 05/10/2003 & 17.2 & 8.6 & .83 & .50 & .11 & .11 & 5 & 25 & 95.0 & 62.0 \\
\hline $05 / 14 / 2003$ & 6.6 & 2.0 & .95 & .39 & .31 & .11 & 9.5 & 18 & 52.0 & 45.0 \\
\hline $05 / 19 / 2003$ & 109.7 & 972.0 & 1.34 & 7.03 & .19 & .11 & 4.9 & 7.1 & 152.4 & $1,965.3$ \\
\hline $05 / 30 / 2003$ & 48.1 & 90.6 & 1.34 & 1.61 & .18 & .23 & 4.7 & 7.9 & 150.0 & 232.0 \\
\hline $07 / 15 / 2003$ & 19.0 & 17.0 & .60 & .52 & .10 & .14 & 5.5 & 7.2 & 64.0 & 61.0 \\
\hline $09 / 12 / 2003$ & 11.0 & 31.0 & .72 & .65 & .32 & .19 & 12 & 10 & 64.0 & 111.0 \\
\hline 05/08/2004 & 76.7 & 17.0 & 1.23 & .64 & .12 & .16 & 21 & 17 & 148.9 & 101.2 \\
\hline 05/10/2004 & 39.2 & 11.2 & .68 & .42 & .07 & .11 & 9.3 & 8.9 & 83.8 & 58.3 \\
\hline 05/13/2004 & -- & -- & -- & -- & -- & -- & -- & -- & -- & -- \\
\hline 05/17/2004 & 21.3 & 41.8 & .52 & .79 & .18 & .20 & 6 & 6.7 & 86.9 & 99.8 \\
\hline $05 / 21 / 2004$ & 43.8 & -- & .62 & -- & .20 & -- & 3.4 & -- & 72.2 & -- \\
\hline $05 / 29 / 2004$ & 69.2 & 2.1 & .66 & .26 & .13 & .11 & 4.1 & 7.7 & 64.3 & 37.0 \\
\hline $06 / 10 / 2004$ & 2.9 & 2.6 & .65 & .41 & .35 & .19 & 16 & 18 & 36.9 & 49.3 \\
\hline 06/10/2004 & 1.6 & 1.8 & .18 & .19 & .08 & .10 & 4.4 & 15 & 14.0 & 23.7 \\
\hline $06 / 24 / 2004$ & 2.2 & 1.7 & .19 & .17 & .09 & .10 & 4.7 & 11 & 22.6 & 24.3 \\
\hline 07/09/2004 & 4.4 & -- & .32 & -- & .11 & -- & 11 & -- & 46.1 & -- \\
\hline $07 / 16 / 2004$ & 5.5 & 5.7 & .43 & .76 & .17 & .22 & 8.6 & 12 & 58.5 & 65.7 \\
\hline $07 / 21 / 2004$ & 2.2 & 2.4 & .24 & .39 & .13 & .23 & 16 & 18 & 19.0 & 36.0 \\
\hline $07 / 29 / 2004$ & 3.1 & 4.8 & .36 & .44 & .12 & .16 & 9.6 & 1.3 & 26.0 & 57.9 \\
\hline 08/03/2004 & 5.6 & 5.3 & .32 & .44 & .08 & .15 & 2 & 1.6 & 36.5 & 45.0 \\
\hline 08/17/2004 & 3.9 & 3.5 & .50 & .54 & .23 & .23 & 2 & 4.3 & 43.6 & 56.0 \\
\hline 08/18/2004 & 4.3 & 3.4 & .37 & .39 & .13 & .17 & 3.4 & 2.2 & 38.0 & 50.4 \\
\hline $08 / 24 / 2004$ & 9.6 & -- & .43 & -- & .24 & -- & 2.4 & -- & 29.1 & -- \\
\hline $08 / 27 / 2004$ & 30.0 & 3.3 & .56 & .42 & .12 & .18 & .8 & 6.2 & 37.0 & 41.0 \\
\hline 09/01/2004 & 5.8 & -- & .29 & -- & .13 & -- & 2.6 & -- & 35.1 & -- \\
\hline $09 / 15 / 2004$ & 5.0 & 3.6 & 1.05 & 1.03 & .53 & .66 & 4.2 & 9.7 & 48.0 & 57.0 \\
\hline
\end{tabular}


Appendix 1. Detailed street-dirt and water-quality data-Continued.

Appendix table 1-8d. Constituent event mean concentrations measured the control and high-frequency broom basin outlets during the treatment phase-Continued.

[ $\mu \mathrm{g} / \mathrm{L}$, microgram per liter; mg/L, milligram per liter; <, less than; --, no data]

\begin{tabular}{|c|c|c|c|c|c|c|c|c|}
\hline \multirow[b]{2}{*}{ Event date } & \multicolumn{2}{|c|}{$\begin{array}{c}\text { Ammonia-nitrogen } \\
\text { (mg/L) }\end{array}$} & \multicolumn{2}{|c|}{$\begin{array}{l}\text { Nitrate plus nitrite, } \\
\text { dissolved } \\
\text { (mg/L) }\end{array}$} & \multicolumn{2}{|c|}{$\begin{array}{c}\text { Dissolved solids, } \\
\text { total } \\
\text { (mg/L) }\end{array}$} & \multicolumn{2}{|c|}{$\begin{array}{c}\text { Suspended sediment, } \\
\text { total } \\
(\mathrm{mg} / \mathrm{L})\end{array}$} \\
\hline & Control & Broom & Control & Broom & Control & Broom & Control & Broom \\
\hline $04 / 30 / 2003$ & 0.78 & 0.98 & 0.49 & 0.64 & 64 & 76 & 308 & 262 \\
\hline $04 / 30 / 2003$ & .32 & .30 & .29 & .24 & 36 & 34 & 1,270 & 422 \\
\hline 05/04/2003 & .38 & .38 & .29 & .35 & 86 & 64 & 280 & 88 \\
\hline 05/10/2003 & .62 & .43 & .45 & .34 & 76 & 60 & 972 & 325 \\
\hline $05 / 14 / 2003$ & .58 & .31 & .41 & .39 & 146 & 70 & 171 & 26 \\
\hline $05 / 19 / 2003$ & .91 & .91 & .78 & .58 & 90 & 64 & 3,193 & 41,418 \\
\hline 05/30/2003 & .77 & .99 & .40 & .50 & 75 & 66 & 1,754 & 5,357 \\
\hline $07 / 15 / 2003$ & .55 & .30 & .54 & .37 & 46 & 32 & 794 & 1,063 \\
\hline $09 / 12 / 2003$ & .77 & .64 & .95 & .70 & 102 & 66 & -- & 2,180 \\
\hline 05/08/2004 & 1.27 & 1.26 & .75 & .68 & 52 & 42 & 3,360 & 599 \\
\hline 05/10/2004 & .70 & .62 & .49 & .44 & 56 & 20 & 1,756 & 464 \\
\hline $05 / 13 / 2004$ & -- & -- & .27 & .28 & 52 & 100 & 155 & 76 \\
\hline 05/17/2004 & .62 & .59 & .35 & .41 & 50 & 66 & 1,036 & 1,971 \\
\hline $05 / 21 / 2004$ & .48 & -- & .42 & -- & 79 & -- & 1,543 & -- \\
\hline 05/29/2004 & .30 & .24 & .30 & .30 & 61 & 60 & 2,992 & 99 \\
\hline $06 / 10 / 2004$ & .49 & .25 & .39 & .30 & 84 & 62 & 132 & 131 \\
\hline $06 / 10 / 2004$ & .22 & .13 & .28 & .29 & 66 & 82 & 55 & 30 \\
\hline $06 / 24 / 2004$ & .26 & .22 & .29 & .35 & 78 & 72 & 62 & 40 \\
\hline 07/09/2004 & .32 & -- & .37 & -- & 52 & -- & 233 & -- \\
\hline $07 / 16 / 2004$ & .29 & .08 & .48 & .36 & 54 & 50 & 261 & 330 \\
\hline $07 / 21 / 2004$ & .28 & .06 & .52 & .47 & 66 & 63 & 36 & 48 \\
\hline $07 / 29 / 2004$ & .34 & .14 & .36 & .30 & 42 & 45 & 197 & 264 \\
\hline 08/03/2004 & .15 & .14 & .30 & .34 & 34 & 44 & 282 & 364 \\
\hline 08/17/2004 & .38 & .29 & .52 & .50 & 31 & 36 & 188 & 213 \\
\hline 08/18/2004 & .30 & .30 & .33 & .34 & 32 & 50 & 188 & 191 \\
\hline $08 / 24 / 2004$ & .21 & -- & .50 & -- & 98 & -- & 146 & -- \\
\hline $08 / 27 / 2004$ & .21 & .18 & .33 & .33 & 98 & 46 & 589 & 124 \\
\hline 09/01/2004 & .26 & -- & .32 & -- & 42 & -- & 207 & -- \\
\hline $09 / 15 / 2004$ & .08 & .20 & .32 & .40 & 80 & 91 & 64 & 86 \\
\hline
\end{tabular}


Appendix 1. Detailed street-dirt and water-quality data-Continued.

Appendix table 1-9a. Constituent event mean loads measured at the control and air-sweeper basin outlets during the calibration phase.

$[<$, less than; nd, no detect; --, no data]

\begin{tabular}{|c|c|c|c|c|c|c|c|c|c|c|}
\hline \multirow[b]{2}{*}{ Event date } & \multicolumn{2}{|c|}{$\begin{array}{l}\text { Cadmium, } \\
\text { total recoverable } \\
\text { (grams) }\end{array}$} & \multicolumn{2}{|c|}{$\begin{array}{c}\text { Calcium, } \\
\text { total recoverable } \\
\text { (kilograms) }\end{array}$} & \multicolumn{2}{|c|}{$\begin{array}{l}\text { Copper, } \\
\text { dissolved } \\
\text { (grams) }\end{array}$} & \multicolumn{2}{|c|}{$\begin{array}{c}\text { Copper, } \\
\text { total recoverable } \\
\text { (grams) }\end{array}$} & \multicolumn{2}{|c|}{$\begin{array}{l}\text { Lead, } \\
\text { total recoverable } \\
\text { (grams) }\end{array}$} \\
\hline & Control & Air & Control & Air & Control & Air & Control & Air & Control & Air \\
\hline 09/07/2001 & 0.42 & 0.24 & 29.9 & 47.9 & nd & 2.99 & 10.42 & 16.42 & 11.34 & 22.39 \\
\hline 09/17/2001 & nd & nd & 21.1 & 19.0 & 2.11 & .95 & 6.05 & 6.05 & 1.97 & 5.61 \\
\hline 09/19/2001 & nd & nd & 5.3 & 2.5 & 2.65 & nd & 2.29 & 1.69 & 2.82 & 1.52 \\
\hline 04/07/2002 & nd & .22 & 36.9 & 11.3 & 5.23 & 2.75 & 23.81 & 13.19 & 12.03 & 8.57 \\
\hline 04/18/2002 & 83.38 & .44 & 83.4 & 64.7 & 3.90 & 2.26 & 38.98 & 28.91 & 30.63 & 31.03 \\
\hline 05/11/2002 & .23 & .35 & 34.5 & 52.8 & 3.07 & 1.61 & 21.00 & 17.70 & 12.12 & 16.09 \\
\hline $05 / 25 / 2002$ & .18 & nd & 9.7 & 8.4 & 3.04 & 2.34 & 9.67 & 10.93 & 1.86 & 3.36 \\
\hline $05 / 28 / 2002$ & .37 & .41 & 35.5 & 104.2 & 4.13 & 3.99 & 22.63 & 27.07 & 13.78 & 19.63 \\
\hline $06 / 02 / 2002$ & .61 & .39 & 155.5 & 66.1 & 10.08 & 4.54 & 29.74 & 29.62 & 26.43 & 21.72 \\
\hline 06/10/2002 & .15 & .30 & 15.9 & 15.1 & 2.33 & .53 & 10.18 & 5.68 & 5.82 & 5.47 \\
\hline $06 / 26 / 2002$ & .29 & .24 & 13.2 & 40.5 & 2.35 & 1.73 & 7.45 & 10.22 & 7.45 & 51.08 \\
\hline 07/22/2002 & .33 & .12 & 22.0 & 5.7 & 4.29 & 2.20 & 14.30 & 3.76 & 8.94 & 45.47 \\
\hline 08/17/2002 & .16 & .09 & 10.7 & 9.5 & 1.47 & .79 & 6.35 & 2.85 & 3.34 & 2.22 \\
\hline 08/21/2002 & .28 & .31 & 16.4 & 56.9 & 2.36 & 2.72 & 10.26 & 12.73 & 7.69 & 13.58 \\
\hline 09/02/2002 & nd & nd & 18.1 & 7.4 & 3.50 & 1.13 & 14.79 & 4.60 & 6.72 & 6.81 \\
\hline 09/19/2002 & nd & .07 & 37.8 & 10.9 & .73 & .40 & 5.79 & 4.20 & 4.63 & 4.40 \\
\hline 09/20/2002 & nd & nd & 1.8 & 1.6 & 2.29 & .53 & 4.64 & 1.39 & 1.13 & 3.05 \\
\hline 04/16/2006 & .36 & 1.53 & 41.9 & 194.7 & nd & nd & 21.23 & 75.95 & 20.85 & 78.78 \\
\hline $04 / 29 / 2006$ & 7.22 & .18 & 31.1 & 9.9 & 1.98 & 1.82 & 36.79 & 9.12 & 16.98 & 1.75 \\
\hline 05/09/2006 & nd & nd & 10.1 & 1.9 & .80 & .46 & 6.94 & 3.50 & 1.35 & nd \\
\hline 05/17/2006 & .03 & nd & 1.5 & 2.9 & nd & nd & 1.39 & 1.93 & .24 & 1.05 \\
\hline 05/24/2006 & .08 & 1.60 & 15.3 & 230.0 & 1.32 & nd & 15.79 & 90.10 & 9.32 & 85.23 \\
\hline 05/30/2006 & .02 & .20 & 10.6 & 55.5 & 2.15 & 1.12 & 10.67 & 17.71 & 4.56 & 21.39 \\
\hline 06/10/2006 & nd & -- & 3.3 & .0 & 1.61 & -- & 3.89 & -- & nd & -- \\
\hline 06/18/2006 & .06 & .05 & 2.8 & 12.2 & .50 & .24 & 2.61 & 6.39 & 1.19 & 3.59 \\
\hline 07/11/2006 & .05 & .03 & 10.8 & 4.7 & nd & .76 & 10.73 & 6.27 & 1.51 & 2.95 \\
\hline 07/20/2006 & nd & -- & 9.6 & .0 & 1.30 & -- & 7.51 & -- & 3.35 & -- \\
\hline $07 / 27 / 2006$ & nd & -- & 8.5 & .0 & nd & -- & 6.80 & -- & 5.19 & -- \\
\hline 08/06/2006 & nd & nd & 3.6 & 5.4 & .75 & .73 & 3.29 & 2.75 & 1.02 & 1.53 \\
\hline 08/17/2006 & nd & nd & 3.7 & 4.3 & .73 & .59 & 3.43 & 3.74 & 1.42 & 1.79 \\
\hline 08/24/2006 & nd & -- & 11.2 & .0 & nd & -- & 7.64 & -- & 5.25 & -- \\
\hline 08/25/2006 & nd & -- & 4.4 & .0 & nd & -- & 3.11 & -- & 2.52 & -- \\
\hline 09/03/2006 & nd & -- & 4.0 & .0 & 1.04 & -- & 2.31 & -- & nd & -- \\
\hline 09/10/2006 & nd & -- & 70.5 & .0 & 4.41 & -- & 20.86 & -- & 14.10 & -- \\
\hline
\end{tabular}


Appendix 1. Detailed street-dirt and water-quality data-Continued.

Appendix table 1-9a. Constituent event mean loads measured at the control and air-sweeper basin outlets during the calibration phase-Continued.

$[<$, less than; nd, no detect; --, no data]

\begin{tabular}{|c|c|c|c|c|c|c|c|c|c|c|}
\hline \multirow[b]{2}{*}{ Event date } & \multicolumn{2}{|c|}{$\begin{array}{c}\text { Magnesium, } \\
\text { total recoverable } \\
\text { (kilograms) }\end{array}$} & \multicolumn{2}{|c|}{$\begin{array}{c}\text { Phosphorus, } \\
\text { total recoverable } \\
\text { (kilograms) }\end{array}$} & \multicolumn{2}{|c|}{$\begin{array}{c}\text { Orthophosphorus, } \\
\text { dissolved } \\
\text { (kilograms) }\end{array}$} & \multicolumn{2}{|c|}{$\begin{array}{c}\text { Zinc, } \\
\text { dissolved } \\
\text { (grams) }\end{array}$} & \multicolumn{2}{|c|}{$\begin{array}{c}\text { Zinc, } \\
\text { total recoverable } \\
\text { (grams) }\end{array}$} \\
\hline & Control & Air & Control & Air & Control & Air & Control & Air & Control & Air \\
\hline 09/07/2001 & 14.82 & 24.78 & 0.70 & 0.67 & 0.30 & 0.21 & 10.65 & 11.05 & 64.83 & 80.62 \\
\hline 09/17/2001 & 11.56 & 10.80 & .19 & .20 & .09 & .06 & 2.99 & 1.04 & 18.36 & 24.19 \\
\hline 09/19/2001 & 2.12 & 1.00 & .17 & .10 & .11 & .06 & 7.59 & 3.78 & 9.70 & 7.39 \\
\hline 04/07/2002 & 16.22 & 4.73 & .38 & .21 & nd & .05 & 7.33 & 8.35 & 75.87 & 58.26 \\
\hline 04/18/2002 & 42.88 & 34.41 & .89 & .71 & .15 & .07 & 8.21 & 3.53 & 135.03 & 134.68 \\
\hline $05 / 11 / 2002$ & 15.18 & 26.49 & .56 & .68 & .08 & .06 & 6.14 & 2.47 & 52.50 & 108.86 \\
\hline 05/25/2002 & 3.80 & 2.73 & .62 & 1.11 & .17 & .39 & 7.60 & 8.59 & 29.69 & 49.18 \\
\hline 05/28/2002 & 17.91 & 52.86 & .66 & .81 & .19 & .22 & 9.55 & 12.18 & 98.40 & 131.31 \\
\hline 06/02/2002 & 75.16 & 30.90 & 1.20 & .67 & .30 & .15 & 24.78 & 6.61 & 92.51 & 96.75 \\
\hline 06/10/2002 & 7.42 & 6.92 & .57 & .46 & .31 & .18 & 5.82 & 5.89 & 39.75 & 62.48 \\
\hline 06/26/2002 & 6.36 & 18.66 & .48 & .42 & .25 & .17 & 9.16 & 5.89 & 40.09 & 169.35 \\
\hline $07 / 22 / 2002$ & 9.92 & 2.45 & .52 & .18 & .18 & .11 & 8.94 & 6.90 & 58.97 & 21.01 \\
\hline 08/17/2002 & 5.35 & 3.65 & .17 & .10 & .05 & .03 & 2.71 & 1.90 & 24.40 & 16.17 \\
\hline $08 / 21 / 2002$ & 7.28 & 28.86 & .30 & .45 & .08 & .13 & 3.69 & 5.43 & 41.03 & 68.76 \\
\hline 09/02/2002 & 8.07 & 3.29 & .54 & .19 & .27 & .10 & 8.60 & 3.35 & 45.71 & 20.43 \\
\hline 09/19/2002 & 20.37 & 5.26 & .20 & .16 & .05 & .03 & 1.58 & 1.02 & 26.62 & 21.19 \\
\hline 09/20/2002 & .80 & .73 & .08 & .05 & .03 & .02 & 2.78 & 1.28 & 7.62 & 6.11 \\
\hline 04/16/2006 & 22.62 & 102.15 & .65 & 2.10 & .08 & .12 & 1.46 & 3.26 & 101.34 & 393.13 \\
\hline 04/29/2006 & 12.88 & 3.50 & 15.57 & .49 & .18 & .14 & 12.74 & 21.29 & 931.14 & 48.67 \\
\hline 05/09/2006 & 3.09 & .64 & 1.24 & .16 & .15 & .04 & 7.29 & 1.69 & 31.94 & 12.26 \\
\hline 05/17/2006 & .56 & 1.19 & .10 & .15 & .03 & .03 & .86 & .78 & 5.67 & 10.86 \\
\hline $05 / 24 / 2006$ & 7.75 & 122.74 & .53 & 3.66 & .08 & .27 & .79 & 3.21 & 43.19 & 442.34 \\
\hline 05/30/2006 & 5.12 & 31.88 & .39 & .80 & .17 & .15 & 2.03 & 1.82 & 24.03 & 89.92 \\
\hline 06/10/2006 & 1.24 & -- & .40 & -- & .18 & -- & 1.11 & -- & 14.84 & -- \\
\hline 06/18/2006 & 1.19 & 5.99 & .15 & .17 & .05 & .03 & 1.80 & .88 & 10.20 & 36.73 \\
\hline 07/11/2006 & 4.41 & 2.04 & .42 & .21 & .14 & .06 & 2.99 & 1.78 & 42.78 & 26.22 \\
\hline 07/20/2006 & 4.17 & -- & .33 & -- & .10 & -- & 3.07 & -- & 28.68 & -- \\
\hline $07 / 27 / 2006$ & 4.06 & -- & .28 & -- & .09 & -- & 3.40 & -- & 33.04 & -- \\
\hline 08/06/2006 & 1.24 & 2.41 & .21 & .21 & .13 & .14 & 1.94 & 2.22 & 11.85 & 10.71 \\
\hline 08/17/2006 & 1.28 & 1.79 & .17 & .21 & .07 & .11 & 1.83 & 2.11 & 15.11 & 20.06 \\
\hline 08/24/2006 & 5.02 & -- & .32 & -- & .11 & -- & 2.74 & -- & 27.37 & -- \\
\hline $08 / 25 / 2006$ & 1.78 & -- & .13 & -- & .05 & -- & 1.85 & -- & 11.86 & -- \\
\hline 09/03/2006 & 1.62 & -- & .18 & -- & .12 & -- & 3.47 & -- & 9.82 & -- \\
\hline 09/10/2006 & 35.26 & -- & .68 & -- & .26 & -- & 7.64 & -- & 70.52 & -- \\
\hline
\end{tabular}


Appendix 1. Detailed street-dirt and water-quality data-Continued.

Appendix table 1-9a. Constituent event mean loads measured at the control and air-sweeper basin outlets during the calibration phase-Continued.

$[<$, less than; nd, no detect; --, no data]

\begin{tabular}{|c|c|c|c|c|c|c|c|c|}
\hline \multirow[b]{2}{*}{ Event date } & \multicolumn{2}{|c|}{$\begin{array}{c}\text { Ammonia-nitrogen } \\
\text { (kilograms) }\end{array}$} & \multicolumn{2}{|c|}{$\begin{array}{l}\text { Nitrate plus nitrite, } \\
\text { dissolved } \\
\text { (kilograms) }\end{array}$} & \multicolumn{2}{|c|}{$\begin{array}{c}\text { Dissolved solids, } \\
\text { total } \\
\text { (kilograms) }\end{array}$} & \multicolumn{2}{|c|}{$\begin{array}{c}\text { Suspended sediment, } \\
\text { total } \\
\text { (kilograms) }\end{array}$} \\
\hline & Control & Air & Control & Air & Control & Air & Control & Air \\
\hline 09/07/2001 & 0.44 & 0.28 & 0.97 & 0.43 & 343 & 66 & 532 & 1,427 \\
\hline 09/17/2001 & nd & .03 & .45 & .22 & 114 & 129 & 109 & 177 \\
\hline 09/19/2001 & .16 & .08 & .51 & .25 & 49 & 25 & 34 & 21 \\
\hline 04/07/2002 & .78 & .35 & .72 & .31 & 188 & 86 & 594 & 118 \\
\hline $04 / 18 / 2002$ & 1.06 & .48 & .56 & .28 & 75 & 49 & 1,728 & 1,787 \\
\hline 05/11/2002 & .31 & .18 & .28 & .10 & 48 & 31 & 689 & 1,425 \\
\hline 05/25/2002 & .40 & .42 & .26 & .30 & 48 & 80 & 296 & 141 \\
\hline $05 / 28 / 2002$ & .89 & .59 & .99 & .68 & 57 & 49 & 837 & 3,026 \\
\hline 06/02/2002 & .93 & .49 & .81 & .42 & 76 & 39 & 5,607 & 1,941 \\
\hline 06/10/2002 & .35 & .19 & .29 & .16 & 39 & 22 & 334 & 280 \\
\hline $06 / 26 / 2002$ & .43 & .26 & .49 & .35 & 24 & 22 & 257 & 1,197 \\
\hline $07 / 22 / 2002$ & .50 & .12 & .41 & .19 & 36 & 16 & 832 & 134 \\
\hline $08 / 17 / 2002$ & .16 & .08 & .25 & .12 & 20 & 10 & 204 & 178 \\
\hline 08/21/2002 & .24 & .21 & .30 & .29 & 94 & 53 & 451 & 1,304 \\
\hline 09/02/2002 & .81 & .30 & .90 & .29 & 83 & 24 & 592 & 284 \\
\hline 09/19/2002 & .10 & .07 & .12 & .06 & 15 & 7 & 511 & 217 \\
\hline 09/20/2002 & .07 & .03 & .08 & .04 & 19 & 8 & 19 & 31 \\
\hline $04 / 16 / 2006$ & .39 & .68 & .33 & .53 & 29 & 75 & 732 & 3,714 \\
\hline 04/29/2006 & .80 & .50 & .62 & .41 & 57 & 58 & 160 & 95 \\
\hline 05/09/2006 & .19 & .14 & .14 & .06 & 45 & 21 & 136 & 31 \\
\hline 05/17/2006 & .06 & .04 & .04 & .04 & 10 & 9 & 23 & 58 \\
\hline $05 / 24 / 2006$ & .51 & 1.34 & .28 & .56 & 47 & 77 & 366 & 5,565 \\
\hline 05/30/2006 & .39 & .41 & .29 & .28 & 73 & 42 & 151 & 1,046 \\
\hline 06/10/2006 & .14 & -- & .16 & -- & 27 & -- & 32 & -- \\
\hline $06 / 18 / 2006$ & .12 & .07 & .14 & .07 & 18 & 12 & 43 & 49 \\
\hline 07/11/2006 & .10 & .02 & nd & nd & 47 & 16 & 187 & 109 \\
\hline 07/20/2006 & .34 & -- & .36 & -- & 30 & -- & 130 & -- \\
\hline 07/27/2006 & .56 & -- & .31 & -- & 40 & -- & 142 & -- \\
\hline 08/06/2006 & .16 & .08 & .22 & .15 & 17 & 15 & 35 & 57 \\
\hline 08/17/2006 & .12 & .11 & .17 & .20 & 12 & 16 & 55 & 76 \\
\hline 08/24/2006 & .64 & -- & .48 & -- & 34 & -- & 197 & -- \\
\hline $08 / 25 / 2006$ & .35 & -- & .39 & -- & 16 & -- & 70 & -- \\
\hline 09/03/2006 & .09 & -- & .18 & -- & 33 & -- & 36 & -- \\
\hline 09/10/2006 & .52 & -- & 1.74 & -- & 658 & -- & 397 & -- \\
\hline
\end{tabular}


Appendix 1. Detailed street-dirt and water-quality data-Continued.

Appendix table 1-9b. Constituent event mean loads measured at the control and high-frequency broom basin outlets during the calibration phase.

$[<$, less than; nd, no detect; --, no data $]$

\begin{tabular}{|c|c|c|c|c|c|c|c|c|c|c|}
\hline \multirow[b]{2}{*}{ Event date } & \multicolumn{2}{|c|}{$\begin{array}{c}\text { Cadmium, } \\
\text { total recoverable } \\
\text { (grams) }\end{array}$} & \multicolumn{2}{|c|}{$\begin{array}{c}\text { Calcium, } \\
\text { total recoverable } \\
\text { (kilograms) }\end{array}$} & \multicolumn{2}{|c|}{$\begin{array}{l}\text { Copper, } \\
\text { dissolved } \\
\text { (grams) }\end{array}$} & \multicolumn{2}{|c|}{$\begin{array}{c}\text { Copper, } \\
\text { total recoverable } \\
\text { (grams) }\end{array}$} & \multicolumn{2}{|c|}{$\begin{array}{c}\text { Lead, } \\
\text { total recoverable } \\
\text { (grams) }\end{array}$} \\
\hline & Control & Broom & Control & Broom & Control & Broom & Control & Broom & Control & Broom \\
\hline 09/07/2001 & 0.42 & -- & 29.9 & -- & nd & -- & 10.42 & -- & 11.34 & -- \\
\hline 09/17/2001 & nd & -- & 21.1 & -- & 2.11 & -- & 6.05 & -- & 1.97 & -- \\
\hline 09/19/2001 & nd & -- & 5.3 & -- & 2.65 & -- & 2.29 & -- & 2.82 & -- \\
\hline $04 / 07 / 2002$ & nd & -- & 36.9 & -- & 5.23 & -- & 23.81 & -- & 12.03 & -- \\
\hline $04 / 18 / 2002$ & 83.38 & -- & 83.4 & -- & 3.90 & -- & 38.98 & -- & 30.63 & -- \\
\hline $05 / 11 / 2002$ & .23 & -- & 34.5 & -- & 3.07 & -- & 21.00 & -- & 12.12 & -- \\
\hline $05 / 25 / 2002$ & .18 & -- & 9.7 & -- & 3.04 & -- & 9.67 & -- & 1.86 & -- \\
\hline $05 / 28 / 2002$ & .37 & -- & 35.5 & -- & 4.13 & -- & 22.63 & -- & 13.78 & -- \\
\hline $06 / 02 / 2002$ & .61 & -- & 155.5 & -- & 10.08 & -- & 29.74 & -- & 26.43 & -- \\
\hline $06 / 10 / 2002$ & .15 & -- & 15.9 & -- & 2.33 & -- & 10.18 & -- & 5.82 & -- \\
\hline $06 / 26 / 2002$ & .29 & -- & 13.2 & -- & 2.35 & -- & 7.45 & -- & 7.45 & -- \\
\hline $07 / 22 / 2002$ & .33 & 0.15 & 22.0 & 5.8 & 4.29 & 4.45 & 14.30 & 6.22 & 8.94 & 1.57 \\
\hline $08 / 17 / 2002$ & .16 & -- & 10.7 & -- & 1.47 & -- & 6.35 & -- & 3.34 & -- \\
\hline $08 / 21 / 2002$ & .28 & -- & 16.4 & -- & 2.36 & -- & 10.26 & -- & 7.69 & -- \\
\hline $09 / 02 / 2002$ & nd & nd & 18.1 & 3.9 & 3.50 & .80 & 14.79 & 2.53 & 6.72 & 1.55 \\
\hline $09 / 19 / 2002$ & nd & -- & 37.8 & -- & .73 & -- & 5.79 & -- & 4.63 & -- \\
\hline $09 / 20 / 2002$ & nd & -- & 1.8 & -- & 2.29 & -- & 4.64 & -- & 1.13 & -- \\
\hline $04 / 06 / 2005$ & .21 & nd & 42.4 & 51.2 & 2.18 & 1.22 & 19.26 & 19.06 & 19.44 & 13.10 \\
\hline $04 / 12 / 2005$ & nd & nd & 5.5 & 7.6 & nd & 1.08 & 5.03 & 6.51 & 2.47 & 2.98 \\
\hline $04 / 19 / 2005$ & nd & -- & 6.7 & -- & .56 & -- & 4.63 & -- & 3.18 & -- \\
\hline 05/06/2005 & .12 & .08 & 11.9 & 11.6 & 1.22 & 1.37 & 11.16 & 11.80 & 6.22 & 5.68 \\
\hline $05 / 11 / 2005$ & nd & nd & 9.9 & 10.7 & 2.39 & 1.84 & 7.38 & 12.16 & 5.38 & 5.54 \\
\hline $05 / 13 / 2005$ & nd & nd & 5.3 & 32.4 & nd & nd & 3.14 & 10.37 & 3.91 & 21.77 \\
\hline $05 / 18 / 2005$ & .12 & .13 & 6.2 & 8.6 & .66 & 1.39 & 4.60 & 6.05 & 4.45 & 3.44 \\
\hline $04 / 16 / 2006$ & .36 & .19 & 41.9 & 28.8 & nd & nd & 21.23 & 18.72 & 20.85 & 16.23 \\
\hline $04 / 29 / 2006$ & 7.22 & nd & 31.1 & 8.4 & 1.98 & 3.06 & 36.79 & 12.23 & 16.98 & 1.30 \\
\hline 05/09/2006 & nd & nd & 10.1 & 1.9 & .80 & .63 & 6.94 & 2.51 & 1.35 & nd \\
\hline 05/17/2006 & .03 & -- & 1.5 & -- & nd & -- & 1.39 & -- & .24 & -- \\
\hline $05 / 24 / 2006$ & .08 & .26 & 15.3 & 85.1 & 1.32 & 7.36 & 15.79 & 62.28 & 9.32 & 38.18 \\
\hline $05 / 30 / 2006$ & .02 & .05 & 10.6 & 12.0 & 2.15 & 1.02 & 10.67 & 8.06 & 4.56 & 7.60 \\
\hline $06 / 10 / 2006$ & nd & nd & 3.3 & 5.1 & 1.61 & .76 & 3.89 & 6.87 & nd & 2.68 \\
\hline $06 / 18 / 2006$ & .06 & -- & 2.8 & -- & .50 & -- & 2.61 & -- & 1.19 & -- \\
\hline $07 / 11 / 2006$ & .05 & .36 & 10.8 & 137.4 & nd & 1.21 & 10.73 & 41.23 & 1.51 & 12.36 \\
\hline $07 / 20 / 2006$ & nd & .89 & 9.6 & 301.1 & 1.30 & 1.33 & 7.51 & 93.96 & 3.35 & 24.36 \\
\hline $07 / 27 / 2006$ & nd & nd & 8.5 & 23.5 & nd & .82 & 6.80 & 10.15 & 5.19 & 6.34 \\
\hline 08/06/2006 & nd & nd & 3.6 & 3.3 & .75 & 1.12 & 3.29 & 8.40 & 1.02 & 1.12 \\
\hline $08 / 17 / 2006$ & nd & .02 & 3.7 & 3.1 & .73 & .54 & 3.43 & 3.05 & 1.42 & .66 \\
\hline $08 / 24 / 2006$ & nd & nd & 11.2 & 9.3 & nd & 1.40 & 7.64 & 11.04 & 5.25 & 7.63 \\
\hline $08 / 25 / 2006$ & nd & nd & 4.4 & 10.1 & nd & nd & 3.11 & 5.04 & 2.52 & 4.22 \\
\hline 09/03/2006 & nd & nd & 4.0 & 3.2 & 1.04 & 1.18 & 2.31 & 3.59 & nd & 2.12 \\
\hline 09/10/2006 & nd & 1.31 & 70.5 & 225.2 & 4.41 & 3.79 & 20.86 & 82.88 & 14.10 & 25.18 \\
\hline
\end{tabular}


Appendix 1. Detailed street-dirt and water-quality data-Continued.

Appendix table 1-9b. Constituent event mean loads measured at the control and high-frequency broom basin outlets during the calibration phase-Continued.

$[<$, less than; nd, no detect; --, no data]

\begin{tabular}{|c|c|c|c|c|c|c|c|c|c|c|}
\hline \multirow[b]{2}{*}{ Event date } & \multicolumn{2}{|c|}{$\begin{array}{c}\text { Magnesium, } \\
\text { total recoverable } \\
\text { (kilograms) }\end{array}$} & \multicolumn{2}{|c|}{$\begin{array}{c}\text { Phosphorus, } \\
\text { total recoverable } \\
\text { (kilograms) }\end{array}$} & \multicolumn{2}{|c|}{$\begin{array}{c}\text { Orthophosphorus, } \\
\text { dissolved } \\
\text { (kilograms) }\end{array}$} & \multicolumn{2}{|c|}{$\begin{array}{c}\text { Zinc, } \\
\text { dissolved } \\
\text { (grams) }\end{array}$} & \multicolumn{2}{|c|}{$\begin{array}{c}\text { Zinc, } \\
\text { total recoverable } \\
\text { (grams) }\end{array}$} \\
\hline & Control & Broom & Control & Broom & Control & Broom & Control & Broom & Control & Broom \\
\hline 09/07/2001 & 14.82 & -- & 0.70 & -- & 0.30 & -- & 10.65 & -- & 64.83 & -- \\
\hline 09/17/2001 & 11.56 & -- & .19 & -- & .09 & -- & 2.99 & -- & 18.36 & -- \\
\hline 09/19/2001 & 2.12 & -- & .17 & -- & .11 & -- & 7.59 & -- & 9.70 & -- \\
\hline 04/07/2002 & 16.22 & -- & .38 & -- & nd & -- & 7.33 & -- & 75.87 & -- \\
\hline $04 / 18 / 2002$ & 42.88 & -- & .89 & -- & .15 & -- & 8.21 & -- & 135.03 & -- \\
\hline 05/11/2002 & 15.18 & -- & .56 & -- & .08 & -- & 6.14 & -- & 52.50 & -- \\
\hline $05 / 25 / 2002$ & 3.80 & -- & .62 & -- & .17 & -- & 7.60 & -- & 29.69 & -- \\
\hline $05 / 28 / 2002$ & 17.91 & -- & .66 & -- & .19 & -- & 9.55 & -- & 98.40 & -- \\
\hline $06 / 02 / 2002$ & 75.16 & -- & 1.20 & -- & .30 & -- & 24.78 & -- & 92.51 & -- \\
\hline $06 / 10 / 2002$ & 7.42 & -- & .57 & -- & .31 & -- & 5.82 & -- & 39.75 & -- \\
\hline $06 / 26 / 2002$ & 6.36 & -- & .48 & -- & .25 & -- & 9.16 & -- & 40.09 & -- \\
\hline $07 / 22 / 2002$ & 9.92 & 2.34 & .52 & 0.45 & .18 & 0.20 & 8.94 & 10.37 & 58.97 & 35.27 \\
\hline 08/17/2002 & 5.35 & -- & .17 & -- & .05 & -- & 2.71 & -- & 24.40 & -- \\
\hline $08 / 21 / 2002$ & 7.28 & -- & .30 & -- & .08 & -- & 3.69 & -- & 41.03 & -- \\
\hline 09/02/2002 & 8.07 & 1.69 & .54 & .16 & .27 & .07 & 8.60 & 3.65 & 45.71 & 17.80 \\
\hline 09/19/2002 & 20.37 & -- & .20 & -- & .05 & -- & 1.58 & -- & 26.62 & -- \\
\hline 09/20/2002 & .80 & -- & .08 & -- & .03 & -- & 2.78 & -- & 7.62 & -- \\
\hline $04 / 06 / 2005$ & 21.43 & 24.72 & .52 & .55 & .11 & .07 & 3.83 & 1.76 & 84.21 & 92.17 \\
\hline $04 / 12 / 2005$ & 2.24 & 3.06 & .18 & .43 & .07 & .07 & 2.24 & 4.18 & 18.28 & 35.33 \\
\hline $04 / 19 / 2005$ & 2.89 & -- & .24 & -- & .10 & -- & 2.46 & -- & 25.16 & -- \\
\hline 05/06/2005 & 5.31 & 5.22 & .27 & .29 & .01 & .02 & 2.76 & 2.55 & 50.15 & 56.44 \\
\hline $05 / 11 / 2005$ & 3.78 & 4.48 & .37 & .40 & .11 & .12 & 5.77 & 8.50 & 38.35 & 56.20 \\
\hline 05/13/2005 & 2.11 & 16.23 & .14 & .22 & .02 & .04 & 2.64 & .70 & 17.14 & 54.38 \\
\hline 05/18/2005 & 2.41 & 2.99 & .22 & .34 & .06 & .10 & 1.08 & 4.18 & 22.39 & 36.79 \\
\hline $04 / 16 / 2006$ & 22.62 & 14.15 & .65 & .64 & .08 & .11 & 1.46 & 2.31 & 101.34 & 87.42 \\
\hline $04 / 29 / 2006$ & 12.88 & 2.83 & 15.57 & .41 & .18 & .09 & 12.74 & 14.53 & 931.14 & 38.99 \\
\hline 05/09/2006 & 3.09 & .57 & 1.24 & .18 & .15 & .05 & 7.29 & 3.77 & 31.94 & 13.82 \\
\hline 05/17/2006 & .56 & -- & .10 & -- & .03 & -- & .86 & -- & 5.67 & -- \\
\hline $05 / 24 / 2006$ & 7.75 & 45.05 & .53 & 2.04 & .08 & .56 & .79 & 4.85 & 43.19 & 208.85 \\
\hline 05/30/2006 & 5.12 & 6.30 & .39 & .39 & .17 & .12 & 2.03 & 2.35 & 24.03 & 36.52 \\
\hline 06/10/2006 & 1.24 & 1.95 & .40 & .50 & .18 & .21 & 1.11 & 1.45 & 14.84 & 30.37 \\
\hline $06 / 18 / 2006$ & 1.19 & -- & .15 & -- & .05 & -- & 1.80 & -- & 10.20 & -- \\
\hline $07 / 11 / 2006$ & 4.41 & 75.61 & .42 & .98 & .14 & .13 & 2.99 & 3.64 & 42.78 & 162.22 \\
\hline 07/20/2006 & 4.17 & 152.35 & .33 & 1.84 & .10 & .13 & 3.07 & 3.00 & 28.68 & 458.79 \\
\hline $07 / 27 / 2006$ & 4.06 & 12.05 & .28 & .43 & .09 & .09 & 3.40 & 2.09 & 33.04 & 42.50 \\
\hline 08/06/2006 & 1.24 & 1.19 & .21 & .22 & .13 & .14 & 1.94 & 2.38 & 11.85 & 15.05 \\
\hline 08/17/2006 & 1.28 & 1.41 & .17 & .10 & .07 & .05 & 1.83 & 1.29 & 15.11 & 10.57 \\
\hline 08/24/2006 & 5.02 & 5.02 & .32 & .43 & .11 & .17 & 2.74 & 2.51 & 27.37 & 39.13 \\
\hline $08 / 25 / 2006$ & 1.78 & 4.85 & .13 & .21 & .05 & .08 & 1.85 & 1.64 & 11.86 & 20.80 \\
\hline 09/03/2006 & 1.62 & 1.26 & .18 & .18 & .12 & .11 & 3.47 & 3.59 & 9.82 & 13.63 \\
\hline 09/10/2006 & 35.26 & 130.06 & .68 & 1.63 & .26 & .29 & 7.64 & 8.65 & 70.52 & $1,796.68$ \\
\hline
\end{tabular}


Appendix 1. Detailed street-dirt and water-quality data-Continued.

Appendix table 1-9b. Constituent event mean loads measured at the control and high-frequency broom basin outlets during the calibration phase-Continued.

$[<$, less than; nd, no detect; --, no data $]$

\begin{tabular}{|c|c|c|c|c|c|c|c|c|}
\hline \multirow[b]{2}{*}{ Event date } & \multicolumn{2}{|c|}{$\begin{array}{l}\text { Ammonia-nitrogen } \\
\text { (kilograms) }\end{array}$} & \multicolumn{2}{|c|}{$\begin{array}{c}\text { Nitrate plus nitrite, } \\
\text { dissolved } \\
\text { (kilograms) }\end{array}$} & \multicolumn{2}{|c|}{$\begin{array}{c}\text { Dissolved solids, } \\
\text { total } \\
\text { (kilograms) }\end{array}$} & \multicolumn{2}{|c|}{$\begin{array}{c}\text { Suspended sediment, } \\
\text { total } \\
\text { (kilograms) }\end{array}$} \\
\hline & Control & Broom & Control & Broom & Control & Broom & Control & Broom \\
\hline $09 / 07 / 2001$ & 0.44 & -- & 0.97 & -- & 343 & -- & 532 & -- \\
\hline 09/17/2001 & nd & -- & .45 & -- & 114 & -- & 109 & -- \\
\hline 09/19/2001 & .16 & -- & .51 & -- & 49 & -- & 34 & -- \\
\hline $04 / 07 / 2002$ & .78 & -- & .72 & -- & 188 & -- & 594 & -- \\
\hline $04 / 18 / 2002$ & 1.06 & -- & .56 & -- & 75 & -- & 1,728 & -- \\
\hline $05 / 11 / 2002$ & .31 & -- & .28 & -- & 48 & -- & 689 & -- \\
\hline $05 / 25 / 2002$ & .40 & -- & .26 & -- & 48 & -- & 296 & -- \\
\hline $05 / 28 / 2002$ & .89 & -- & .99 & -- & 57 & -- & 837 & -- \\
\hline $06 / 02 / 2002$ & .93 & -- & .81 & -- & 76 & -- & 5,607 & -- \\
\hline 06/10/2002 & .35 & -- & .29 & -- & 39 & -- & 334 & -- \\
\hline $06 / 26 / 2002$ & .43 & -- & .49 & -- & 24 & -- & 257 & -- \\
\hline $07 / 22 / 2002$ & .50 & nd & .41 & nd & 36 & 28 & 832 & 150 \\
\hline $08 / 17 / 2002$ & .16 & -- & .25 & -- & 20 & -- & 204 & -- \\
\hline $08 / 21 / 2002$ & .24 & -- & .30 & -- & 94 & -- & 451 & -- \\
\hline $09 / 02 / 2002$ & .81 & .16 & .90 & .26 & 83 & 23 & 592 & 72 \\
\hline 09/19/2002 & .10 & -- & .12 & -- & 15 & -- & 511 & -- \\
\hline 09/20/2002 & .07 & -- & .08 & -- & 19 & -- & 19 & -- \\
\hline $04 / 06 / 2005$ & .79 & .52 & .36 & .29 & 75 & 53 & 478 & 936 \\
\hline $04 / 12 / 2005$ & .38 & .41 & .47 & .54 & 27 & 37 & 46 & 64 \\
\hline $04 / 19 / 2005$ & .34 & -- & .21 & -- & 22 & -- & 78 & -- \\
\hline 05/06/2005 & .35 & .40 & .20 & .24 & 18 & 19 & 207 & 186 \\
\hline $05 / 11 / 2005$ & .43 & .41 & .29 & .27 & 33 & 43 & 119 & 170 \\
\hline $05 / 13 / 2005$ & .23 & .24 & .23 & .24 & 19 & 30 & 76 & 916 \\
\hline 05/18/2005 & .30 & .41 & .36 & .49 & 29 & 42 & 66 & 100 \\
\hline $04 / 16 / 2006$ & .39 & .33 & .33 & .30 & 29 & 37 & 732 & 699 \\
\hline $04 / 29 / 2006$ & .80 & .47 & .62 & .37 & 57 & 51 & 160 & 203 \\
\hline 05/09/2006 & .19 & .14 & .14 & .12 & 45 & 21 & 136 & 25 \\
\hline $05 / 17 / 2006$ & .06 & -- & .04 & -- & 10 & -- & 23 & -- \\
\hline $05 / 24 / 2006$ & .51 & 1.40 & .28 & 1.02 & 47 & 169 & 366 & 2,204 \\
\hline 05/30/2006 & .39 & .21 & .29 & .23 & 73 & 41 & 151 & 376 \\
\hline $06 / 10 / 2006$ & .14 & .16 & .16 & .09 & 27 & 18 & 32 & 160 \\
\hline $06 / 18 / 2006$ & .12 & -- & .14 & -- & 18 & -- & 43 & -- \\
\hline $07 / 11 / 2006$ & .10 & nd & nd & .51 & 47 & 41 & 187 & 3,063 \\
\hline $07 / 20 / 2006$ & .34 & .22 & .36 & .28 & 30 & 21 & 130 & 7,776 \\
\hline $07 / 27 / 2006$ & .56 & .31 & .31 & .22 & 40 & 25 & 142 & 534 \\
\hline 08/06/2006 & .16 & .05 & .22 & .16 & 17 & 17 & 35 & 53 \\
\hline $08 / 17 / 2006$ & .12 & .04 & .17 & .10 & 12 & 6 & 55 & 76 \\
\hline $08 / 24 / 2006$ & .64 & .39 & .48 & .44 & 34 & 32 & 197 & 543 \\
\hline $08 / 25 / 2006$ & .35 & .25 & .39 & .34 & 16 & 20 & 70 & 81 \\
\hline 09/03/2006 & .09 & .09 & .18 & .12 & 33 & 30 & 36 & 73 \\
\hline 09/10/2006 & .52 & .22 & 1.74 & .52 & 658 & 112 & 397 & 6,292 \\
\hline
\end{tabular}


Appendix 1. Detailed street-dirt and water-quality data-Continued.

Appendix table 1-9c. Constituent event mean loads measured at the control and air-sweeper basin outlets during the treatment phase.

$[<$, less than; nd, no detect; --, no data]

\begin{tabular}{|c|c|c|c|c|c|c|c|c|c|c|c|}
\hline \multirow{2}{*}{ 离 } & \multirow[b]{2}{*}{ Event date } & \multicolumn{2}{|c|}{$\begin{array}{l}\text { Cadmium, } \\
\text { total recoverable } \\
\text { (grams) }\end{array}$} & \multicolumn{2}{|c|}{$\begin{array}{c}\text { Calcium, } \\
\text { total recoverable } \\
\text { (kilograms) }\end{array}$} & \multicolumn{2}{|c|}{$\begin{array}{l}\text { Copper, } \\
\text { dissolved } \\
\text { (grams) }\end{array}$} & \multicolumn{2}{|c|}{$\begin{array}{c}\text { Copper, } \\
\text { total recoverable } \\
\text { (grams) }\end{array}$} & \multicolumn{2}{|c|}{$\begin{array}{c}\text { Lead, } \\
\text { total recoverable } \\
\text { (grams) }\end{array}$} \\
\hline & & Control & Air & Control & Air & Control & Air & Control & Air & Control & Air \\
\hline \multirow{14}{*}{ 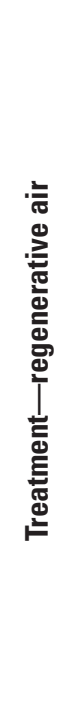 } & $04 / 30 / 2003$ & 0.35 & 0.17 & 13.2 & 11.9 & 2.86 & 3.78 & 11.86 & 12.18 & 8.37 & 6.15 \\
\hline & $04 / 30 / 2003$ & 1.22 & nd & 105.9 & 82.4 & 2.15 & nd & 26.95 & 31.16 & 15.36 & 24.29 \\
\hline & $05 / 04 / 2003$ & .42 & nd & 18.5 & 3.5 & 1.46 & 1.13 & 9.47 & 3.59 & 3.06 & 1.50 \\
\hline & 05/10/2003 & .20 & .13 & 26.8 & 13.5 & 3.15 & 1.07 & 26.24 & 7.92 & 12.46 & 5.15 \\
\hline & $05 / 14 / 2003$ & nd & nd & 7.1 & 2.0 & 1.02 & .55 & 5.44 & 2.15 & 1.80 & .61 \\
\hline & 05/19/2003 & 17.50 & .13 & 106.4 & 21.0 & 3.24 & 1.65 & 27.11 & 10.72 & 6.69 & 7.15 \\
\hline & 05/30/2003 & .13 & .21 & 26.4 & 65.3 & .63 & .77 & 13.05 & 16.74 & 8.97 & 11.59 \\
\hline & $07 / 15 / 2003$ & .19 & .54 & 44.5 & 22.5 & 3.77 & 26.29 & 18.28 & 18.21 & 14.85 & 22.53 \\
\hline & $09 / 12 / 2003$ & .03 & nd & 4.7 & 3.7 & 2.36 & .83 & 5.31 & 2.39 & 1.95 & 1.27 \\
\hline & 05/08/2004 & nd & nd & 61.2 & 25.4 & 3.25 & 1.78 & 17.00 & 8.22 & 14.18 & 9.80 \\
\hline & 05/10/2004 & .08 & .07 & 26.7 & 34.3 & 1.51 & .98 & 8.28 & 7.86 & 6.64 & 9.59 \\
\hline & $05 / 13 / 2004$ & -- & -- & -- & -- & -- & -- & -- & -- & -- & -- \\
\hline & 05/17/2004 & nd & .23 & 22.6 & 86.6 & 2.61 & 3.01 & 12.20 & 21.04 & 12.09 & 30.10 \\
\hline & $05 / 21 / 2004$ & nd & .20 & 36.4 & 24.6 & .79 & 1.28 & 10.28 & 13.19 & 9.60 & 17.61 \\
\hline \multirow{22}{*}{ 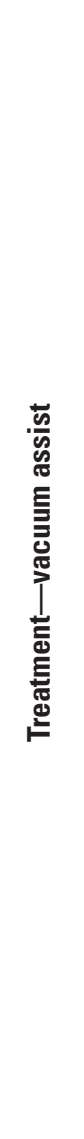 } & 05/29/2004 & nd & nd & 142.9 & 11.3 & 2.18 & 4.11 & 77.19 & 9.23 & 26.58 & 6.38 \\
\hline & 06/10/2004 & nd & nd & 1.4 & 2.5 & 1.00 & .50 & 1.98 & 1.83 & .72 & 1.19 \\
\hline & 06/10/2004 & nd & -- & 3.5 & .0 & 3.37 & -- & 2.68 & -- & 1.15 & -- \\
\hline & 06/24/2004 & .07 & nd & 1.3 & .6 & .66 & .31 & 1.21 & .56 & .79 & .48 \\
\hline & 07/09/2004 & .08 & .08 & 2.7 & 9.1 & 1.76 & 1.60 & 3.61 & 6.31 & 2.07 & 5.82 \\
\hline & $07 / 16 / 2004$ & nd & .15 & 5.8 & 12.8 & 1.97 & 1.82 & 6.04 & 9.15 & 3.30 & 9.43 \\
\hline & $07 / 21 / 2004$ & nd & nd & 1.6 & 1.1 & 1.07 & .45 & 1.51 & 1.04 & nd & .65 \\
\hline & 07/29/2004 & .17 & .15 & 5.9 & 7.6 & 2.16 & 1.79 & 4.23 & 5.99 & 1.99 & 5.58 \\
\hline & 08/03/2004 & .14 & .07 & 7.6 & 23.8 & nd & nd & 4.75 & 16.20 & 5.91 & 16.58 \\
\hline & 08/17/2004 & nd & nd & 2.0 & 3.2 & nd & nd & 1.74 & 2.30 & 1.11 & 2.06 \\
\hline & 08/18/2004 & .06 & nd & 2.6 & 12.0 & nd & nd & 5.64 & 8.48 & 1.06 & 8.87 \\
\hline & 08/24/2004 & .04 & nd & 3.0 & 1.9 & nd & .28 & 1.67 & 1.98 & .45 & 1.07 \\
\hline & 08/27/2004 & nd & .11 & 6.6 & 3.5 & nd & nd & 1.98 & 3.21 & .80 & 2.85 \\
\hline & 09/01/2004 & .06 & nd & 6.0 & 22.2 & nd & nd & 4.61 & 16.64 & 4.06 & 33.82 \\
\hline & $09 / 15 / 2004$ & nd & nd & 5.4 & 2.4 & 1.33 & .84 & 5.40 & 2.28 & 1.45 & .92 \\
\hline & 04/06/2005 & .21 & .16 & 42.4 & 23.6 & 2.18 & 1.81 & 19.26 & 13.14 & 19.44 & 11.29 \\
\hline & $04 / 12 / 2005$ & nd & nd & 5.5 & 1.0 & nd & .30 & 5.03 & 1.45 & 2.47 & .59 \\
\hline & $04 / 19 / 2005$ & nd & .08 & 6.7 & 16.4 & .56 & .48 & 4.63 & 8.36 & 3.18 & 6.52 \\
\hline & 05/06/2005 & .12 & .01 & 11.9 & 9.8 & 1.22 & .83 & 11.16 & 7.14 & 6.22 & 6.14 \\
\hline & $05 / 11 / 2005$ & nd & nd & 9.9 & 5.4 & 2.39 & .82 & 7.38 & 5.05 & 5.38 & 3.53 \\
\hline & $05 / 13 / 2005$ & nd & nd & 5.3 & 6.1 & nd & nd & 3.14 & 4.00 & 3.91 & 3.51 \\
\hline & 05/18/2005 & .12 & nd & 6.2 & 3.0 & .66 & .55 & 4.60 & 2.46 & 4.45 & 1.75 \\
\hline
\end{tabular}


Appendix 1. Detailed street-dirt and water-quality data-Continued.

Appendix table 1-9c. Constituent event mean loads measured at the control and air-sweeper basin outlets during the treatment phase-Continued.

$[<$, less than; nd, no detect; --, no data]

\begin{tabular}{|c|c|c|c|c|c|c|c|c|c|c|c|}
\hline \multirow{2}{*}{ 递 } & \multirow[b]{2}{*}{ Event date } & \multicolumn{2}{|c|}{$\begin{array}{l}\text { Magnesium, } \\
\text { total recoverable } \\
\text { (kilograms) }\end{array}$} & \multicolumn{2}{|c|}{$\begin{array}{c}\text { Phosphorus, } \\
\text { total recoverable } \\
\text { (kilograms) }\end{array}$} & \multicolumn{2}{|c|}{$\begin{array}{c}\text { Orthophosphorus, } \\
\text { dissolved } \\
\text { (kilograms) }\end{array}$} & \multicolumn{2}{|c|}{$\begin{array}{c}\text { Zinc, } \\
\text { dissolved } \\
\text { (grams) }\end{array}$} & \multicolumn{2}{|c|}{$\begin{array}{c}\text { Zinc, } \\
\text { total recoverable } \\
\text { (grams) }\end{array}$} \\
\hline & & Control & Air & Control & Air & Control & Air & Control & Air & Control & Air \\
\hline \multirow{14}{*}{ 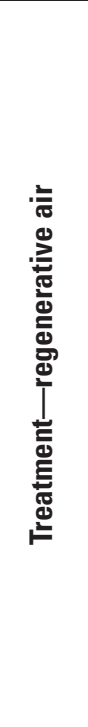 } & $04 / 30 / 2003$ & 5.72 & 4.94 & 0.50 & 0.48 & 0.14 & 0.19 & 8.37 & 10.26 & 59.98 & 57.06 \\
\hline & $04 / 30 / 2003$ & 57.63 & 41.32 & .97 & .75 & .12 & .09 & 6.76 & 5.83 & 133.23 & 118.47 \\
\hline & $05 / 04 / 2003$ & 6.63 & 1.04 & 2.94 & .15 & nd & .06 & 5.25 & 4.17 & 80.87 & 15.43 \\
\hline & $05 / 10 / 2003$ & 11.28 & 5.42 & .55 & .34 & .07 & .05 & 3.28 & 2.61 & 62.31 & 43.94 \\
\hline & $05 / 14 / 2003$ & 2.24 & .57 & .32 & .13 & .11 & .05 & 3.23 & 2.15 & 17.68 & 9.67 \\
\hline & $05 / 19 / 2003$ & 56.46 & 10.05 & .69 & .39 & .10 & .08 & 2.52 & 4.42 & 78.46 & 56.30 \\
\hline & $05 / 30 / 2003$ & 13.08 & 32.97 & .36 & .52 & .05 & .08 & 1.28 & 1.16 & 40.79 & 88.86 \\
\hline & $07 / 15 / 2003$ & 21.70 & 9.76 & .69 & .63 & .11 & .24 & 6.28 & 118.30 & 73.10 & 69.48 \\
\hline & $09 / 12 / 2003$ & 2.16 & 1.14 & .14 & .09 & .06 & .05 & 2.36 & 1.20 & 12.58 & 12.88 \\
\hline & 05/08/2004 & 29.69 & 10.51 & .48 & .47 & .05 & .03 & 8.13 & 7.36 & 57.69 & 50.37 \\
\hline & 05/10/2004 & 13.16 & 19.16 & .23 & .25 & .02 & .02 & 3.12 & 3.92 & 28.13 & 53.55 \\
\hline & $05 / 13 / 2004$ & -- & -- & -- & -- & -- & -- & -- & -- & -- & -- \\
\hline & $05 / 17 / 2004$ & 11.58 & 41.96 & .28 & .67 & .10 & .17 & 3.26 & 75.72 & 47.30 & 120.47 \\
\hline & $05 / 21 / 2004$ & 19.14 & 12.62 & .27 & .45 & .09 & .10 & 1.48 & 3.20 & 31.54 & 70.54 \\
\hline \multirow{22}{*}{ 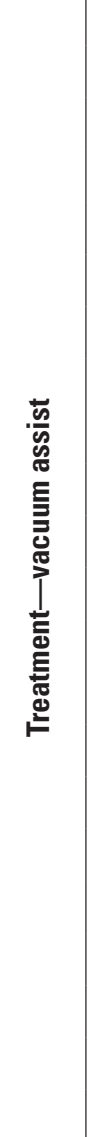 } & $05 / 29 / 2004$ & 71.79 & 5.43 & .69 & .24 & .13 & .07 & 4.25 & 5.50 & 66.67 & 40.93 \\
\hline & $06 / 10 / 2004$ & .56 & .87 & .12 & .06 & .07 & .02 & 3.03 & 1.56 & 6.99 & 10.42 \\
\hline & $06 / 10 / 2004$ & 1.16 & -- & .13 & -- & .06 & -- & 3.15 & -- & 10.02 & -- \\
\hline & $06 / 24 / 2004$ & .48 & .19 & .04 & .02 & .02 & .01 & 1.04 & .99 & 4.99 & 3.04 \\
\hline & 07/09/2004 & 1.34 & 4.55 & .10 & .11 & .03 & .04 & 3.34 & 3.12 & 13.99 & 31.49 \\
\hline & $07 / 16 / 2004$ & 2.71 & 6.38 & .21 & .25 & .08 & .08 & 4.24 & 3.85 & 28.85 & 53.67 \\
\hline & $07 / 21 / 2004$ & .56 & .42 & .06 & .05 & .03 & .02 & 4.09 & 3.40 & 4.86 & 7.45 \\
\hline & $07 / 29 / 2004$ & 2.57 & 3.58 & .30 & .29 & .10 & .08 & 7.96 & 6.27 & 21.55 & 35.12 \\
\hline & 08/03/2004 & 3.79 & 12.66 & .22 & .50 & .05 & .12 & 1.36 & 1.20 & 24.79 & 75.92 \\
\hline & $08 / 17 / 2004$ & .87 & 1.47 & .11 & .12 & .05 & .05 & .45 & .82 & 9.72 & 29.22 \\
\hline & $08 / 18 / 2004$ & 1.17 & 6.52 & .10 & .30 & .04 & .08 & .92 & .94 & 10.28 & 47.00 \\
\hline & $08 / 24 / 2004$ & 1.49 & .86 & .07 & .08 & .04 & .04 & .37 & 1.54 & 4.50 & 10.64 \\
\hline & $08 / 27 / 2004$ & 3.49 & 1.67 & .07 & .15 & .01 & .06 & .09 & 1.41 & 4.31 & 15.70 \\
\hline & $09 / 01 / 2004$ & 2.99 & 12.15 & .15 & .68 & .07 & .15 & 1.35 & 2.06 & 18.17 & 80.74 \\
\hline & $09 / 15 / 2004$ & 2.08 & .87 & .44 & .24 & .22 & .12 & 1.74 & 1.29 & 19.94 & 13.38 \\
\hline & $04 / 06 / 2005$ & 21.43 & 11.36 & .52 & .33 & .11 & .06 & 3.83 & 2.16 & 84.21 & 74.21 \\
\hline & $04 / 12 / 2005$ & 2.24 & .32 & .18 & .04 & .07 & .02 & 2.24 & 1.89 & 18.28 & 6.24 \\
\hline & $04 / 19 / 2005$ & 2.89 & 7.85 & .24 & .34 & .10 & .11 & 2.46 & 1.84 & 25.16 & 53.47 \\
\hline & 05/06/2005 & 5.31 & 4.37 & .27 & .23 & .01 & nd & 2.76 & 3.80 & 50.15 & 48.50 \\
\hline & $05 / 11 / 2005$ & 3.78 & 1.90 & .37 & .21 & .11 & .09 & 5.77 & 5.32 & 38.35 & 28.11 \\
\hline & $05 / 13 / 2005$ & 2.11 & 2.82 & .14 & .12 & .02 & .02 & 2.64 & 1.12 & 17.14 & 24.08 \\
\hline & $05 / 18 / 2005$ & 2.41 & 1.09 & .22 & .11 & .06 & .02 & 1.08 & 1.42 & 22.39 & 13.64 \\
\hline
\end{tabular}


Appendix 1. Detailed street-dirt and water-quality data-Continued.

Appendix table 1-9c. Constituent event mean loads measured at the control and air-sweeper basin outlets during the treatment phase-Continued.

$[<$, less than; nd, no detect; --, no data]

\begin{tabular}{|c|c|c|c|c|c|c|c|c|c|}
\hline \multirow{2}{*}{ 离 } & \multirow[b]{2}{*}{ Event date } & \multicolumn{2}{|c|}{$\begin{array}{c}\text { Ammonia-nitrogen } \\
\text { (kilograms) }\end{array}$} & \multicolumn{2}{|c|}{$\begin{array}{l}\text { Nitrate plus nitrite, } \\
\text { dissolved } \\
\text { (kilograms) }\end{array}$} & \multicolumn{2}{|c|}{$\begin{array}{c}\text { Dissolved solids, } \\
\text { total } \\
\text { (kilograms) }\end{array}$} & \multicolumn{2}{|c|}{$\begin{array}{c}\text { Suspended sediment, } \\
\text { total } \\
\text { (kilograms) }\end{array}$} \\
\hline & & Control & Air & Control & Air & Control & Air & Control & Air \\
\hline \multirow{14}{*}{ 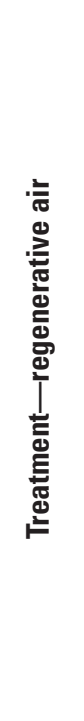 } & $04 / 30 / 2003$ & 0.54 & 0.55 & 0.34 & 0.32 & 45 & 56 & 215 & 193 \\
\hline & $04 / 30 / 2003$ & .49 & .36 & .45 & .30 & 55 & 52 & 1,951 & 1,332 \\
\hline & $05 / 04 / 2003$ & .28 & .18 & .21 & .06 & 63 & 30 & 204 & 43 \\
\hline & 05/10/2003 & .41 & .17 & .29 & .10 & 50 & 37 & 638 & 217 \\
\hline & $05 / 14 / 2003$ & .20 & .05 & .14 & .07 & 50 & 16 & 58 & 20 \\
\hline & $05 / 19 / 2003$ & .47 & .38 & .40 & .27 & 46 & 31 & 1,643 & 378 \\
\hline & $05 / 30 / 2003$ & .21 & .30 & .11 & .21 & 20 & 29 & 477 & 1,144 \\
\hline & $07 / 15 / 2003$ & .63 & .73 & .62 & .62 & 53 & 39 & 907 & 2,524 \\
\hline & $09 / 12 / 2003$ & .15 & .14 & .19 & .15 & 20 & 17 & -- & -- \\
\hline & 05/08/2004 & .49 & .36 & .29 & .27 & 20 & 20 & 1,301 & 414 \\
\hline & $05 / 10 / 2004$ & .23 & .20 & .16 & .14 & 19 & 10 & 589 & 503 \\
\hline & 05/13/2004 & -- & -- & .04 & .04 & 8 & 8 & 25 & 17 \\
\hline & $05 / 17 / 2004$ & .34 & .48 & .19 & .29 & 27 & 38 & 564 & 1,287 \\
\hline & $05 / 21 / 2004$ & .21 & .30 & .18 & .25 & 35 & 34 & 674 & 621 \\
\hline \multirow{22}{*}{ 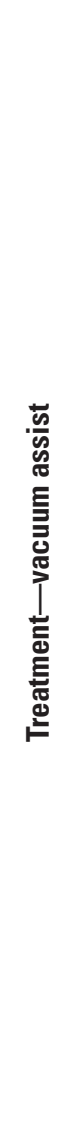 } & $05 / 29 / 2004$ & .31 & .21 & .31 & .24 & 63 & 45 & 3,104 & 268 \\
\hline & $06 / 10 / 2004$ & .09 & .04 & .07 & .06 & 16 & 12 & 25 & 36 \\
\hline & 06/10/2004 & .16 & -- & .20 & -- & 47 & -- & 40 & -- \\
\hline & $06 / 24 / 2004$ & .06 & .03 & .06 & .03 & 17 & 8 & 14 & 4 \\
\hline & 07/09/2004 & .10 & .12 & .11 & .15 & 16 & 18 & 71 & 171 \\
\hline & $07 / 16 / 2004$ & .14 & .15 & .24 & .25 & 27 & 29 & 129 & 270 \\
\hline & $07 / 21 / 2004$ & .07 & .05 & .13 & .09 & 17 & 10 & 9 & 13 \\
\hline & $07 / 29 / 2004$ & .28 & .24 & .30 & .28 & 35 & 39 & 164 & 200 \\
\hline & 08/03/2004 & .10 & .17 & .20 & .31 & 23 & 53 & 191 & 666 \\
\hline & 08/17/2004 & .08 & .09 & .12 & .14 & 7 & 10 & 42 & 64 \\
\hline & 08/18/2004 & .08 & .18 & .09 & .15 & 9 & 24 & 51 & 296 \\
\hline & 08/24/2004 & .03 & .04 & .08 & .07 & 15 & 8 & 23 & 39 \\
\hline & $08 / 27 / 2004$ & .02 & .08 & .04 & .11 & 11 & 15 & 69 & 58 \\
\hline & 09/01/2004 & .14 & .40 & .17 & .45 & 22 & 55 & 107 & 673 \\
\hline & $09 / 15 / 2004$ & .03 & .04 & .13 & .13 & 33 & 21 & 27 & 19 \\
\hline & 04/06/2005 & .79 & .43 & .36 & .20 & 75 & 43 & 478 & 470 \\
\hline & $04 / 12 / 2005$ & .38 & .11 & .47 & .12 & 27 & 8 & 46 & 7 \\
\hline & 04/19/2005 & .34 & .29 & .21 & .20 & 22 & 27 & 78 & 200 \\
\hline & 05/06/2005 & .35 & .38 & .20 & .23 & 18 & 21 & 207 & 143 \\
\hline & $05 / 11 / 2005$ & .43 & .28 & .29 & .20 & 33 & 25 & 119 & 85 \\
\hline & $05 / 13 / 2005$ & .23 & .20 & .23 & .21 & 19 & 20 & 76 & 103 \\
\hline & 05/18/2005 & .30 & .16 & .36 & .21 & 29 & 19 & 66 & 28 \\
\hline
\end{tabular}


Appendix 1. Detailed street-dirt and water-quality data-Continued.

Appendix table 1-9d. Constituent event mean loads measured at the control and high-frequency broom basin outlets during the treatment phase.

$[<$, less than; nd, no detect; --, no data]

\begin{tabular}{|c|c|c|c|c|c|c|c|c|c|c|}
\hline \multirow[b]{2}{*}{ Event date } & \multicolumn{2}{|c|}{$\begin{array}{l}\text { Cadmium, } \\
\text { total recoverable } \\
\text { (grams) }\end{array}$} & \multicolumn{2}{|c|}{$\begin{array}{c}\text { Calcium, } \\
\text { total recoverable } \\
\text { (kilograms) }\end{array}$} & \multicolumn{2}{|c|}{$\begin{array}{l}\text { Copper, } \\
\text { dissolved } \\
\text { (grams) }\end{array}$} & \multicolumn{2}{|c|}{$\begin{array}{c}\text { Copper, } \\
\text { total recoverable } \\
\text { (grams) }\end{array}$} & \multicolumn{2}{|c|}{$\begin{array}{c}\text { Lead, } \\
\text { total recoverable } \\
\text { (grams) }\end{array}$} \\
\hline & Control & Broom & Control & Broom & Control & Broom & Control & Broom & Control & Broom \\
\hline $04 / 30 / 2003$ & 0.35 & nd & 13.2 & 3.4 & 2.86 & 0.90 & 11.86 & 2.74 & 8.37 & 1.02 \\
\hline 04/30/2003 & 1.22 & .20 & 105.9 & 18.5 & 2.15 & 1.28 & 26.95 & 10.39 & 15.36 & 35.98 \\
\hline $05 / 04 / 2003$ & .42 & nd & 18.5 & 2.9 & 1.46 & .88 & 9.47 & 2.57 & 3.06 & .85 \\
\hline 05/10/2003 & .20 & .17 & 26.8 & 14.9 & 3.15 & 1.52 & 26.24 & 7.27 & 12.46 & 4.63 \\
\hline $05 / 14 / 2003$ & nd & nd & 7.1 & 1.6 & 1.02 & 2.54 & 5.44 & 2.35 & 1.80 & .43 \\
\hline 05/19/2003 & 17.50 & .14 & 106.4 & 630.9 & 3.24 & 1.31 & 27.11 & 251.09 & 6.69 & 111.97 \\
\hline 05/30/2003 & .13 & .09 & 26.4 & 36.1 & .63 & .36 & 13.05 & 7.90 & 8.97 & 5.46 \\
\hline 07/15/2003 & .19 & nd & 44.5 & 36.1 & 3.77 & 2.58 & 18.28 & 15.46 & 14.85 & 13.40 \\
\hline 09/12/2003 & .03 & nd & 4.7 & 15.0 & 2.36 & .95 & 5.31 & 4.54 & 1.95 & 2.02 \\
\hline 05/08/2004 & nd & nd & 61.2 & 11.8 & 3.25 & 2.26 & 17.00 & 8.37 & 14.18 & 4.58 \\
\hline 05/10/2004 & .08 & nd & 26.7 & 15.8 & 1.51 & 2.24 & 8.28 & 9.41 & 6.64 & 6.98 \\
\hline 05/13/2004 & -- & -- & -- & -- & -- & -- & -- & -- & -- & -- \\
\hline 05/17/2004 & nd & .13 & 22.6 & 52.4 & 2.61 & 3.05 & 12.20 & 15.24 & 12.09 & 10.68 \\
\hline $05 / 21 / 2004$ & nd & -- & 36.4 & -- & .79 & -- & 10.28 & -- & 9.60 & -- \\
\hline 05/29/2004 & nd & nd & 142.9 & 7.1 & 2.18 & 5.33 & 77.19 & 10.17 & 26.58 & 3.73 \\
\hline 06/10/2004 & nd & nd & 1.4 & 1.8 & 1.00 & 1.08 & 1.98 & 2.59 & .72 & .68 \\
\hline 06/10/2004 & nd & nd & 3.5 & 3.5 & 3.37 & 4.05 & 2.68 & 6.76 & 1.15 & .25 \\
\hline $06 / 24 / 2004$ & .07 & nd & 1.3 & .8 & .66 & .46 & 1.21 & .89 & .79 & .01 \\
\hline 07/09/2004 & .08 & -- & 2.7 & -- & 1.76 & -- & 3.61 & -- & 2.07 & -- \\
\hline 07/16/2004 & nd & nd & 5.8 & 6.4 & 1.97 & 1.41 & 6.04 & 6.57 & 3.30 & 6.15 \\
\hline $07 / 21 / 2004$ & nd & nd & 1.6 & 1.1 & 1.07 & .52 & 1.51 & .90 & nd & nd \\
\hline 07/29/2004 & .17 & nd & 5.9 & 7.2 & 2.16 & nd & 4.23 & 8.30 & 1.99 & 3.89 \\
\hline 08/03/2004 & .14 & nd & 7.6 & 6.3 & nd & nd & 4.75 & 6.18 & 5.91 & 4.37 \\
\hline 08/17/2004 & nd & nd & 2.0 & 1.4 & nd & .43 & 1.74 & 2.63 & 1.11 & 1.20 \\
\hline 08/18/2004 & .06 & .05 & 2.6 & 1.7 & nd & nd & 5.64 & 2.37 & 1.06 & 1.18 \\
\hline $08 / 24 / 2004$ & .04 & -- & 3.0 & -- & nd & -- & 1.67 & -- & .45 & -- \\
\hline 08/27/2004 & nd & nd & 6.6 & .7 & nd & .15 & 1.98 & .69 & .80 & .62 \\
\hline 09/01/2004 & .06 & -- & 6.0 & -- & nd & -- & 4.61 & -- & 4.06 & -- \\
\hline 09/15/2004 & nd & nd & 5.4 & 2.8 & 1.33 & .99 & 5.40 & 3.31 & 1.45 & .88 \\
\hline
\end{tabular}


Appendix 1. Detailed street-dirt and water-quality data-Continued.

Appendix table 1-9d. Constituent event mean loads measured at the control and high-frequency broom basin outlets during the treatment phase-Continued.

$[<$, less than; nd, no detect; --, no data]

\begin{tabular}{|c|c|c|c|c|c|c|c|c|c|c|}
\hline \multirow[b]{2}{*}{ Event date } & \multicolumn{2}{|c|}{$\begin{array}{c}\text { Magnesium, } \\
\text { total recoverable } \\
\text { (kilograms) }\end{array}$} & \multicolumn{2}{|c|}{$\begin{array}{c}\text { Phosphorus, } \\
\text { total recoverable } \\
\text { (kilograms) }\end{array}$} & \multicolumn{2}{|c|}{$\begin{array}{c}\text { Orthophosphorus, } \\
\text { dissolved } \\
\text { (kilograms) }\end{array}$} & \multicolumn{2}{|c|}{$\begin{array}{c}\text { Zinc, } \\
\text { dissolved } \\
\text { (grams) }\end{array}$} & \multicolumn{2}{|c|}{$\begin{array}{c}\text { Zinc, } \\
\text { total recoverable } \\
\text { (grams) }\end{array}$} \\
\hline & Control & Broom & Control & Broom & Control & Broom & Control & Broom & Control & Broom \\
\hline $04 / 30 / 2003$ & 5.72 & 1.41 & 0.50 & 0.13 & 0.14 & 0.05 & 8.37 & 2.93 & 59.98 & 15.72 \\
\hline $04 / 30 / 2003$ & 57.63 & 7.28 & .97 & .24 & .12 & .07 & 6.76 & 4.40 & 133.23 & 40.77 \\
\hline 05/04/2003 & 6.63 & .81 & 2.94 & .09 & nd & .03 & 5.25 & 3.73 & 80.87 & 12.19 \\
\hline 05/10/2003 & 11.28 & 5.69 & .55 & .33 & .07 & .07 & 3.28 & 16.53 & 62.31 & 40.99 \\
\hline $05 / 14 / 2003$ & 2.24 & .39 & .32 & .08 & .11 & .02 & 3.23 & 3.52 & 17.68 & 8.81 \\
\hline 05/19/2003 & 56.46 & 310.87 & .69 & 2.25 & .10 & .04 & 2.52 & 2.27 & 78.46 & 628.56 \\
\hline $05 / 30 / 2003$ & 13.08 & 17.04 & .36 & .30 & .05 & .04 & 1.28 & 1.49 & 40.79 & 43.64 \\
\hline $07 / 15 / 2003$ & 21.70 & 17.52 & .69 & .54 & .11 & .14 & 6.28 & 7.42 & 73.10 & 62.88 \\
\hline $09 / 12 / 2003$ & 2.16 & 7.04 & .14 & .15 & .06 & .04 & 2.36 & 2.27 & 12.58 & 25.22 \\
\hline 05/08/2004 & 29.69 & 5.84 & .48 & .22 & .05 & .05 & 8.13 & 5.82 & 57.69 & 34.65 \\
\hline 05/10/2004 & 13.16 & 7.37 & .23 & .27 & .02 & .07 & 3.12 & 5.87 & 28.13 & 38.47 \\
\hline $05 / 13 / 2004$ & -- & -- & -- & -- & -- & -- & -- & -- & -- & -- \\
\hline 05/17/2004 & 11.58 & 25.01 & .28 & .47 & .10 & .12 & 3.26 & 4.01 & 47.30 & 59.66 \\
\hline $05 / 21 / 2004$ & 19.14 & -- & .27 & -- & .09 & -- & 1.48 & -- & 31.54 & -- \\
\hline 05/29/2004 & 71.79 & 2.52 & .69 & .30 & .13 & .13 & 4.25 & 9.13 & 66.67 & 43.81 \\
\hline $06 / 10 / 2004$ & .56 & .71 & .12 & .11 & .07 & .05 & 3.03 & 4.87 & 6.99 & 13.33 \\
\hline $06 / 10 / 2004$ & 1.16 & 1.15 & .13 & .12 & .06 & .06 & 3.15 & 9.50 & 10.02 & 15.04 \\
\hline $06 / 24 / 2004$ & .48 & .26 & .04 & .02 & .02 & .01 & 1.04 & 1.65 & 4.99 & 3.63 \\
\hline 07/09/2004 & 1.34 & -- & .10 & -- & .03 & -- & 3.34 & -- & 13.99 & -- \\
\hline $07 / 16 / 2004$ & 2.71 & 2.86 & .21 & .38 & .08 & .11 & 4.24 & 6.02 & 28.85 & 32.98 \\
\hline $07 / 21 / 2004$ & .56 & .37 & .06 & .06 & .03 & .04 & 4.09 & 2.78 & 4.86 & 5.56 \\
\hline $07 / 29 / 2004$ & 2.57 & 3.12 & .30 & .29 & .10 & .11 & 7.96 & .85 & 21.55 & 37.84 \\
\hline 08/03/2004 & 3.79 & 3.19 & .22 & .26 & .05 & .09 & 1.36 & .96 & 24.79 & 26.90 \\
\hline 08/17/2004 & .87 & .66 & .11 & .10 & .05 & .04 & .45 & .81 & 9.72 & 10.54 \\
\hline 08/18/2004 & 1.17 & .72 & .10 & .08 & .04 & .04 & .92 & .47 & 10.28 & 10.85 \\
\hline $08 / 24 / 2004$ & 1.49 & -- & .07 & -- & .04 & -- & .37 & -- & 4.50 & -- \\
\hline $08 / 27 / 2004$ & 3.49 & .31 & .07 & .04 & .01 & .02 & .09 & .58 & 4.31 & 3.82 \\
\hline 09/01/2004 & 2.99 & -- & .15 & -- & .07 & -- & 1.35 & -- & 18.17 & -- \\
\hline 09/15/2004 & 2.08 & .99 & .44 & .28 & .22 & .18 & 1.74 & 2.67 & 19.94 & 15.70 \\
\hline
\end{tabular}


Appendix 1. Detailed street-dirt and water-quality data-Continued.

Appendix table 1-9d. Constituent event mean loads measured at the control and high-frequency broom basin outlets during the treatment phase-Continued.

$[<$, less than; nd, no detect; --, no data]

\begin{tabular}{|c|c|c|c|c|c|c|c|c|}
\hline \multirow[b]{2}{*}{ Event date } & \multicolumn{2}{|c|}{$\begin{array}{c}\text { Ammonia-nitrogen } \\
\text { (kilograms) }\end{array}$} & \multicolumn{2}{|c|}{$\begin{array}{l}\text { Nitrate plus nitrite, } \\
\text { dissolved } \\
\text { (kilograms) }\end{array}$} & \multicolumn{2}{|c|}{$\begin{array}{c}\text { Dissolved solids, } \\
\text { total } \\
\text { (kilograms) }\end{array}$} & \multicolumn{2}{|c|}{$\begin{array}{c}\text { Suspended sediment, } \\
\text { total } \\
\text { (kilograms) }\end{array}$} \\
\hline & Control & Broom & Control & Broom & Control & Broom & Control & Broom \\
\hline $04 / 30 / 2003$ & 0.54 & 0.18 & 0.34 & 0.12 & 45 & 14 & 215 & 48 \\
\hline $04 / 30 / 2003$ & .49 & .24 & .45 & .19 & 55 & 27 & 1,951 & 337 \\
\hline $05 / 04 / 2003$ & .28 & .13 & .21 & .12 & 63 & 22 & 204 & 30 \\
\hline 05/10/2003 & .41 & .28 & .29 & .22 & 50 & 40 & 638 & 215 \\
\hline $05 / 14 / 2003$ & .20 & .06 & .14 & .08 & 50 & 14 & 58 & 5 \\
\hline 05/19/2003 & .47 & .29 & .40 & .18 & 46 & 20 & 1,643 & 13,247 \\
\hline $05 / 30 / 2003$ & .21 & .19 & .11 & .09 & 20 & 12 & 477 & 1,008 \\
\hline $07 / 15 / 2003$ & .63 & .31 & .62 & .38 & 53 & 33 & 907 & 1,096 \\
\hline $09 / 12 / 2003$ & .15 & .15 & .19 & .16 & 20 & 15 & -- & 495 \\
\hline 05/08/2004 & .49 & .43 & .29 & .23 & 20 & 14 & 1,301 & 205 \\
\hline $05 / 10 / 2004$ & .23 & .41 & .16 & .29 & 19 & 13 & 589 & 306 \\
\hline $05 / 13 / 2004$ & -- & -- & .04 & .05 & 8 & 18 & 25 & 14 \\
\hline 05/17/2004 & .34 & .35 & .19 & .24 & 27 & 39 & 564 & 1,179 \\
\hline $05 / 21 / 2004$ & .21 & -- & .18 & -- & 35 & -- & 674 & -- \\
\hline $05 / 29 / 2004$ & .31 & .28 & .31 & .35 & 63 & 71 & 3,104 & 117 \\
\hline 06/10/2004 & .09 & .07 & .07 & .08 & 16 & 17 & 25 & 35 \\
\hline 06/10/2004 & .16 & .08 & .20 & .18 & 47 & 52 & 40 & 19 \\
\hline $06 / 24 / 2004$ & .06 & .03 & .06 & .05 & 17 & 11 & 14 & 6 \\
\hline 07/09/2004 & .10 & -- & .11 & -- & 16 & -- & 71 & -- \\
\hline $07 / 16 / 2004$ & .14 & .04 & .24 & .18 & 27 & 25 & 129 & 166 \\
\hline $07 / 21 / 2004$ & .07 & .01 & .13 & .07 & 17 & 10 & 9 & 7 \\
\hline $07 / 29 / 2004$ & .28 & .09 & .30 & .20 & 35 & 29 & 164 & 173 \\
\hline 08/03/2004 & .10 & .08 & .20 & .20 & 23 & 26 & 191 & 218 \\
\hline 08/17/2004 & .08 & .05 & .12 & .09 & 7 & 7 & 42 & 40 \\
\hline 08/18/2004 & .08 & .06 & .09 & .07 & 9 & 11 & 51 & 41 \\
\hline $08 / 24 / 2004$ & .03 & -- & .08 & -- & 15 & -- & 23 & -- \\
\hline $08 / 27 / 2004$ & .02 & .02 & .04 & .03 & 11 & 4 & 69 & 12 \\
\hline 09/01/2004 & .14 & -- & .17 & -- & 22 & -- & 107 & -- \\
\hline $09 / 15 / 2004$ & .03 & .06 & .13 & .11 & 33 & 25 & 27 & 24 \\
\hline
\end{tabular}




\section{Appendix 2. Quality assurance and quality control}

Field and sample-processing equipment blanks were collected at the control and test-basin monitoring stations to evaluate the integrity of the stormwater-quality sampling process, identify if sample contamination existed and if so, to identify possible sources. Blank samples were obtained by drawing deionized water through the suction line and sampler into a collection bottle. The Teflon sample line and automatic sampler were not cleaned before obtaining blank samples. Blank water collected in the 10-liter glass sample bottle was then split using a Teflon-lined churn splitter into plastic laboratory-prepared sample bottles. Samples were placed on ice and delivered to the Madison Department of Public Health (MDPH) for analysis. Deionized blank water was also used to isolate individual elements of the sampling process from source to delivery. These samples were not delivered to the MDPH unless erroneous concentrations were found in the original blank sample. Blank-sample results are detailed in table 2-1. Replicate samples were also collected to evaluate the inherent variability in the sampling analyses and methods. The bias and variability identified by analysis of blanks and replicates were within acceptable limits except for dissolved zinc, dissolved chloride, and total cadmium.

Total zinc concentrations often were above detectable limits but were typically an order of magnitude lower than those measured in stormwater-quality samples. Dissolved zinc concentrations, however, were detected in blanks at concentrations greater than in field samples at each of the stormwater-quality monitoring stations. The median dissolved zinc concentration, for all blank samples with dissolved zinc concentrations above the limit of detection, was 1.0 micrograms per liter. The minimum dissolved zinc concentration from a stormwater-quality sample taken at the control, air-sweeper, and high-frequency basins was $0.8,1.0$, and 1.3, respectively. Analyses of deionized water used for blank samples, with no exposure to sample or processing equipment, indicated a presence of total and dissolved zinc concentrations that was greater than the detectable range in field samples. It is possible that zinc concentrations detected in many blank samples may have come from the deionized water. Contamination of dissolved zinc could also have come from a source other than the deionized water. Additional blank samples taken to isolate individual elements of the sampling process had dissolved zinc concentrations that were slightly higher than the deionized water. Deionized water was used only as a rinse during sample bottle cleaning, therefore any dis- solved zinc residue remaining on field sample collection bottles after cleaning would be insignificant when compared to the mass of water in the field samples.

Dissolved chloride concentrations in blanks were also greater than the detectable limit and concentration in field samples at each of the monitoring stations on several occasions. Follow-up tests of the deionized water used in the blank sample process resulted in concentrations of dissolved chloride less than the detectable limit. One explanation for elevated dissolved chloride levels in the control basin may be due to the periodic drainage of a private swimming pool into basin storm drains. Similarly, fire hydrants in each basin were flushed twice per year onto adjacent streets. Water feeding the hydrants originated from a chlorinated city water supply. For these reasons, and since no obvious source of chloride was detected in the stormwater-quality sampling equipment, dissolved chloride was disregarded from statistical evaluation.

Finally, total cadmium was detected in the control basin blank sample on one occasion. This sample had been contaminated in the analytical laboratory and does not reflect the efficacy of the stormwater-quality sampling equipment.

Replicate samples were submitted to verify reproducibility in the sample acquisition and splitting process as well as analytical methods conducted in the laboratory. Replicate samples were checked for precision on the basis of an absolute relative percent difference (RPD). Replicate-sample results are detailed in table 2-2. On several occasions within each basin, the RPD values exceeded 50 percent. The majority of these samples were acquired prior to identifying the potential bias in concentration data due to the presence of sand-size particles in a wholewater sample (Selbig and others, 2007). Changes to the sample-splitting and laboratory analytical techniques were implemented in May 2004. The RPD values for replicate samples collected after May 2004 were mostly within an acceptable range of error. Of the RPD values exceeding 50 percent after the new methods were used, the majority occurred from a single replicate (table 2-2). Due to laboratory error, the new sample-splitting techniques were not used to process this sample which was likely the cause of the differences. This sample was therefore not used as part of the replicate analysis. 


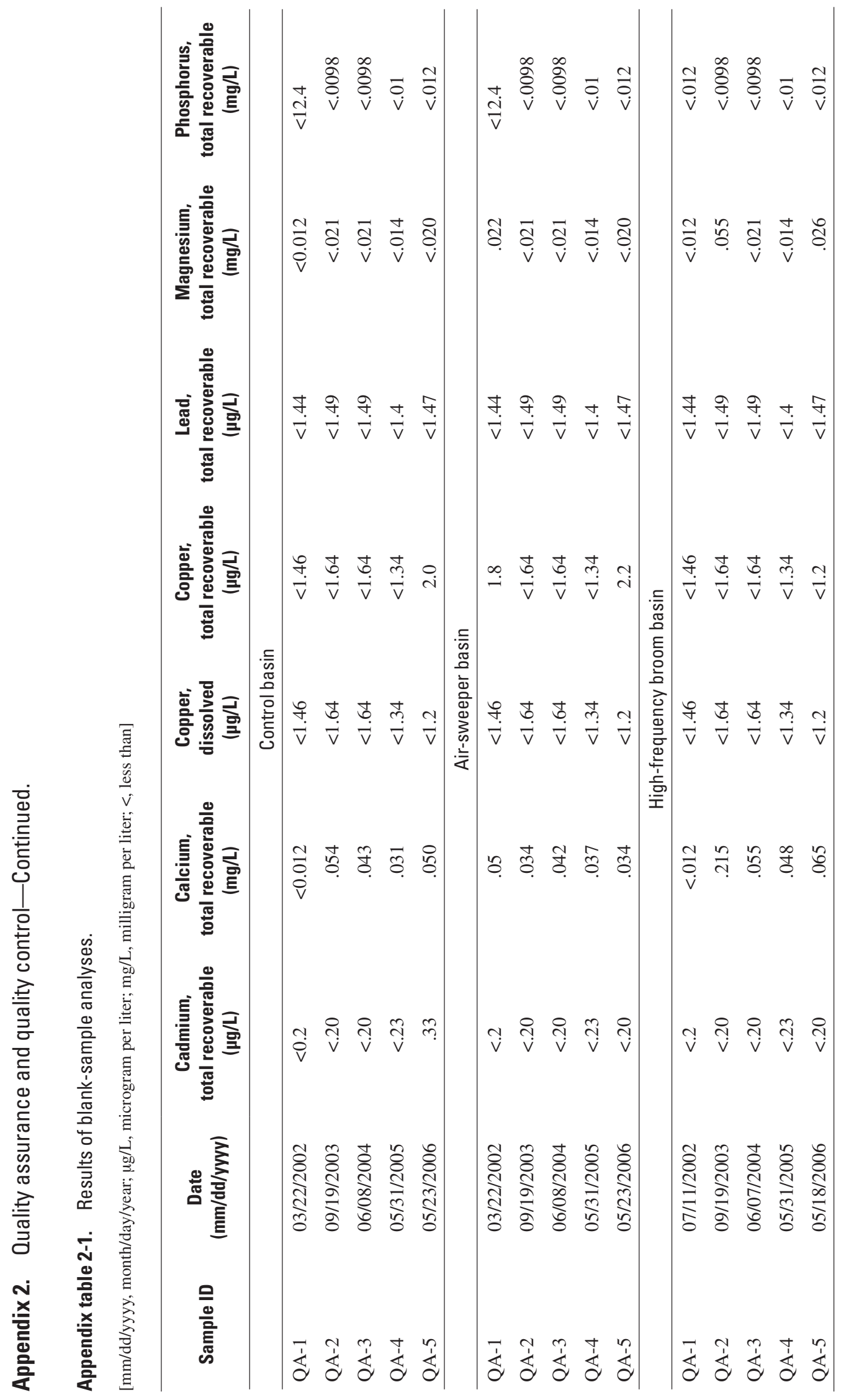




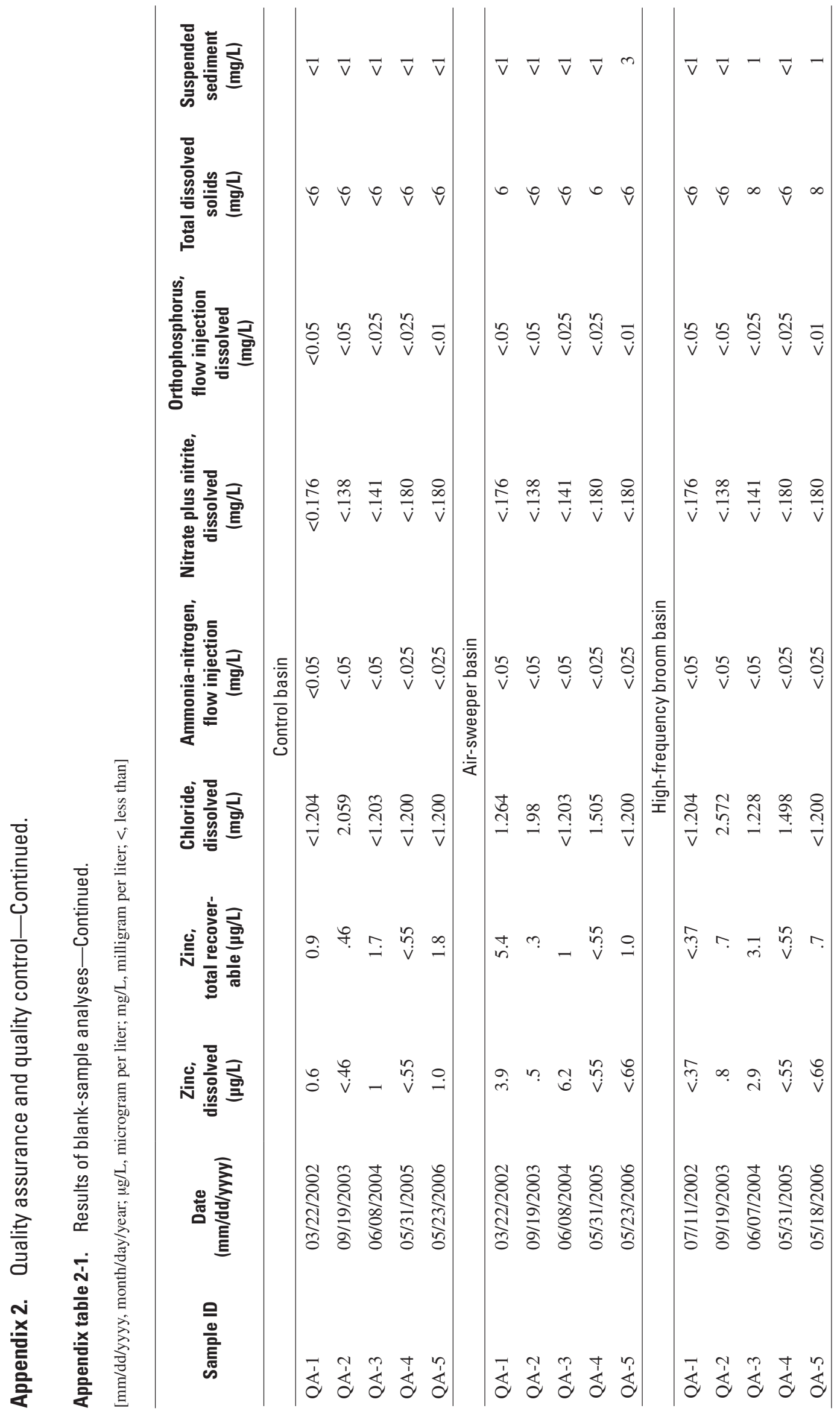




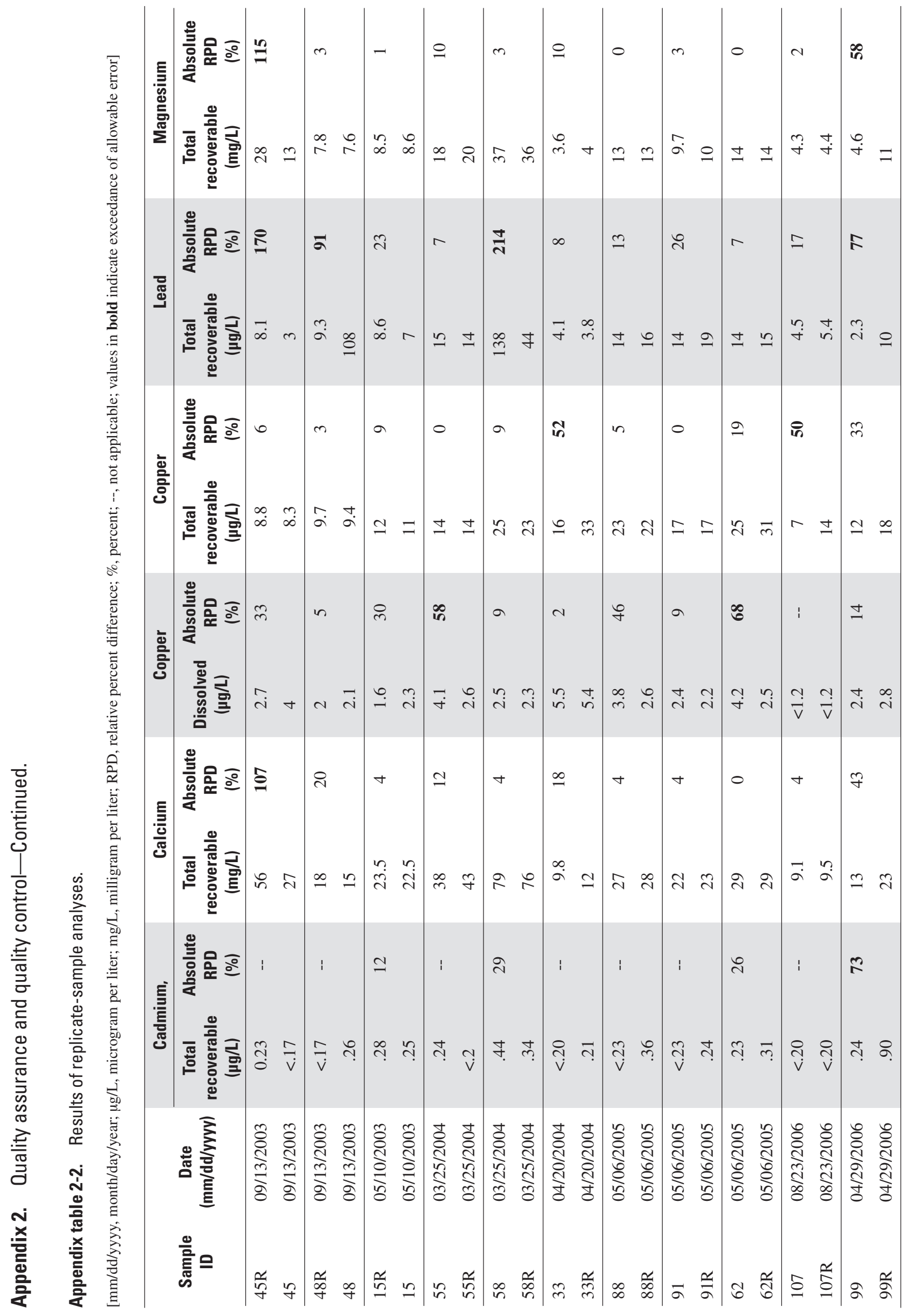




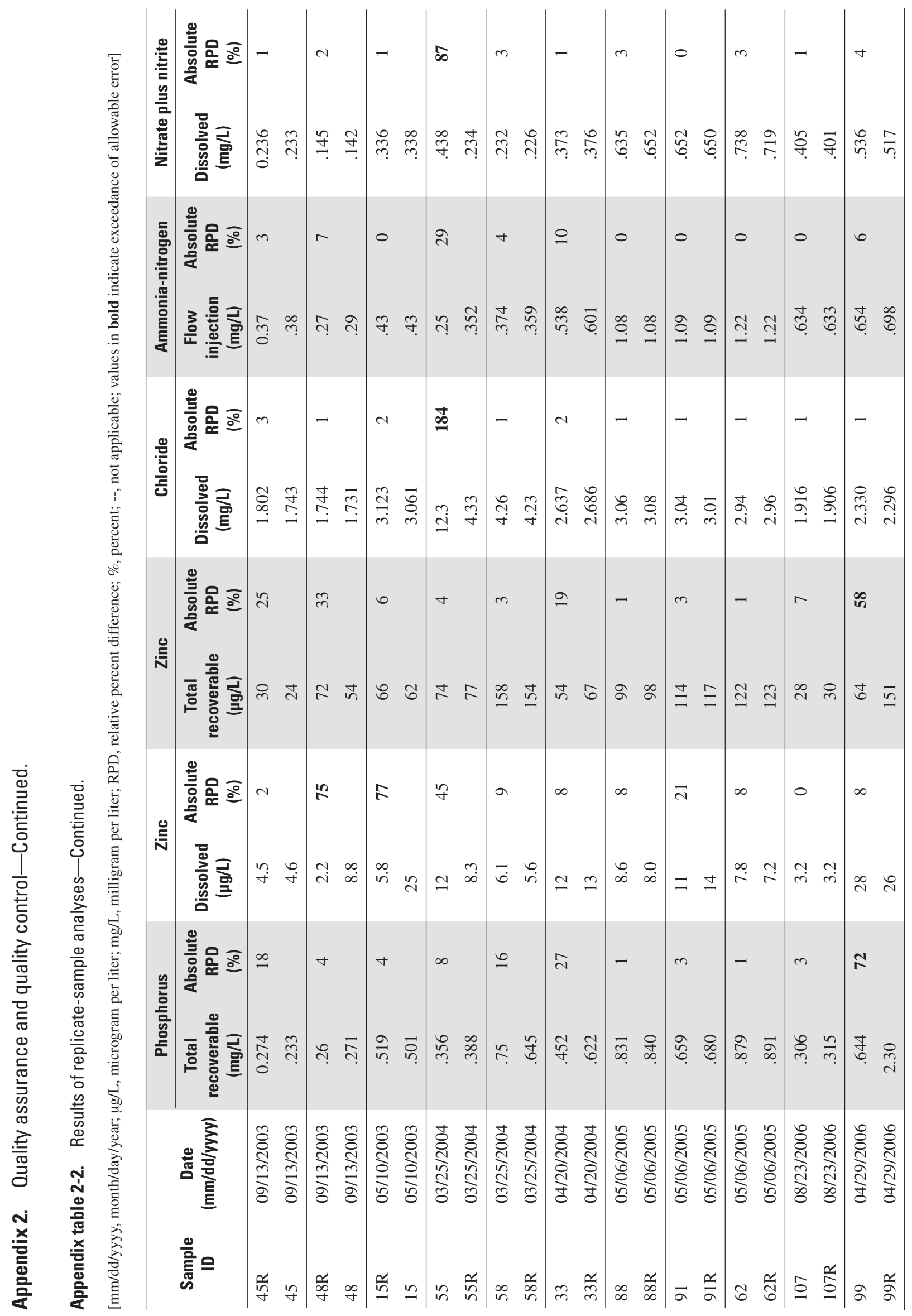




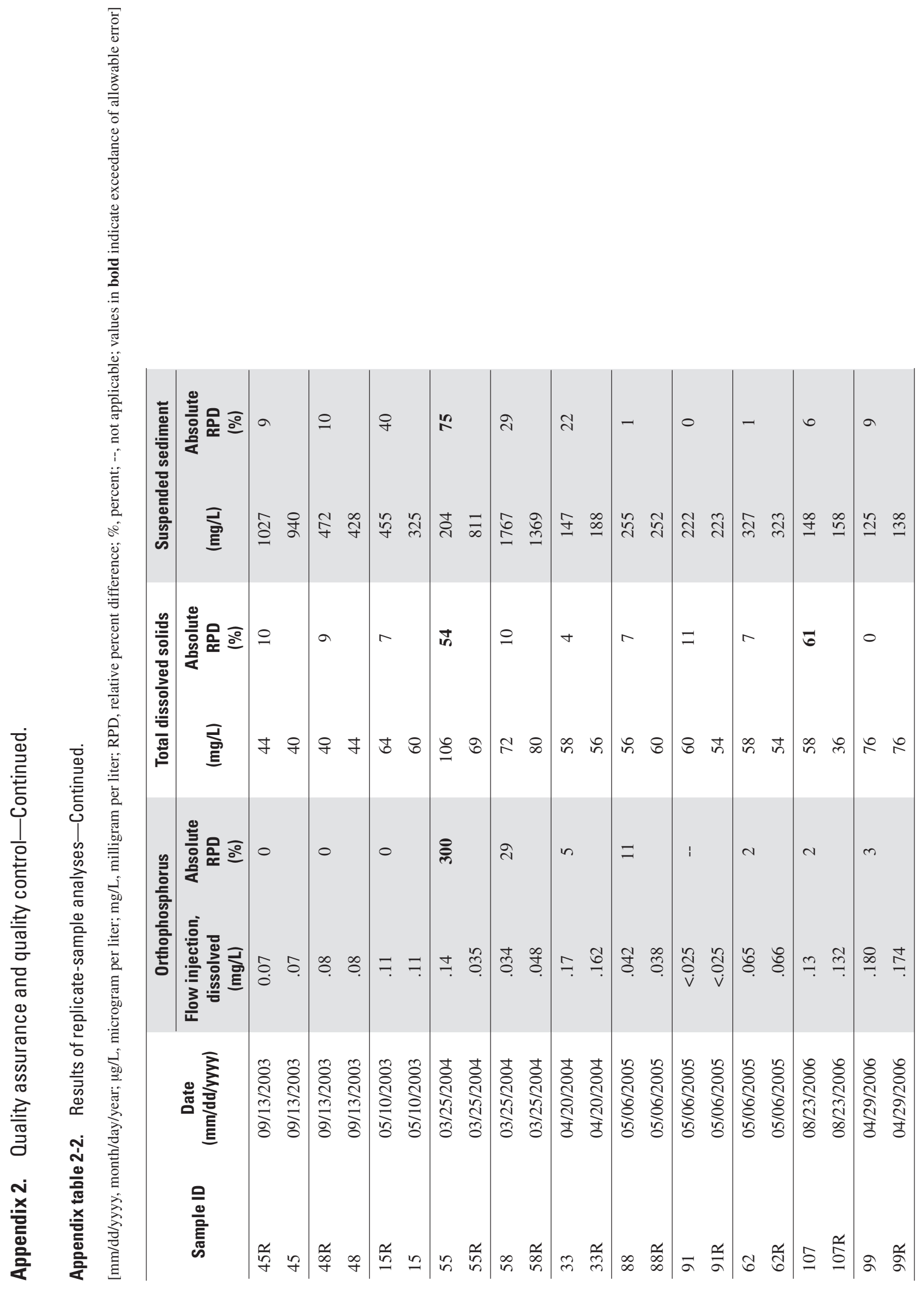


Prepared by the Wisconsin Water Science Center:

U.S. Geological Survey

Wisconsin Water Science Center

8505 Research Way

Middleton, WI 53562

tel: (608) 828-9901

fax: (608) 821-3817

This publication is available online at URL:

http://pubs.water.usgs.gov/sir2007-5156

Information regarding the Wisconsin Water Science Center is available at URL:

http://wi.water.usgs.gov 
